
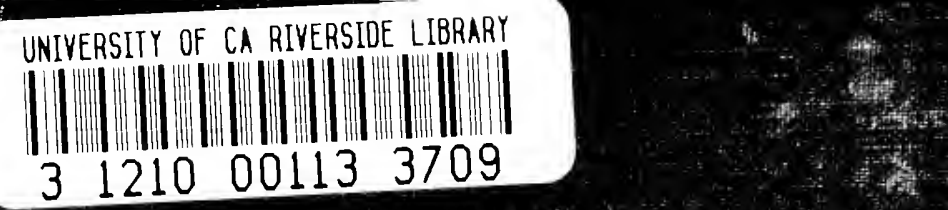


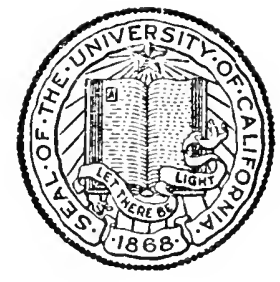

THE LIBRARY

OF

THE UNIVERSITY

OF CALIFORNIA RIVERSIDE 




\title{
The Development of
}

\section{Hungarian}

\section{Constitutional Liberty.}

BY

\section{COUNT JULIUS ANDRÁSSY.}

\author{
Translated from the Hungarian by \\ C. ARTHUR AND ILONA GINEVER.
}




$$
\text { JN2OSS }
$$




\section{DEVELOPMENT OF IIUNGARIAN LIBERTY.}

\section{CONTENTS.}

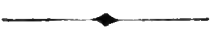

PART I.

THE CREATION OF THE HUNGARIAN STATE.

Chapter.

I. The Time of the Árpads.

Page.

3

39

II. The Time of the Mixed Dynasies.

P.IRL II.

THE DEVELOPNENT OF THE CUNSTITUTION.

III. Sources of the Royal Power.

IV. The First Beginnings of a Constitution in IIungary anı in England during the Eleventh and Twelfth centuries.

V. The Thirteenth Century. Steps towards Freedom in England and Hungary. The Charters.

VI, The Thirtecnih Century. Struggle for Political Power. V!ctory of the Monarchy in England. Exaggeration of Freedom in Hungary. The Century's Results in the Two Cuuntries.

VII. Monrichical Reaction in Iungary. The Angevins.

VIII. Development of the Constitution in England.

IX. The Development of the ITungarian Constitution from the time of the Angevins to the Accession of Matthias. P'ART 1. To the I leath of sigismund (I 4 ' 3 ).

$X$. The Development of the Hungarian Constitution from the time of the Angevins to the Accession of Matthias. I'ART U. I'eriod of Jisintegration. From the Accessim of albert to the Teath of Ladislas V. (I+57). 


\section{DEVEIOPMENT OF HUNGARIAN LIBERTY.}

\section{CONTENTS - (Continued).}

Chapter.

XI. Reaction in favour of the Monarchy in England. The Tudors.

Page.

XII. Royal Reaction in Hungary King Matthias.

XIII. The Jagello Dynasty. Struggles between Nobles and Gentry. King Wladislav II.

XIV. Louis II. ( $1516-1526)$

264

XV. The Foundation of the Duminion of the Habsurgs

293

XVI. Division of the Country.

311

XVII. Efforts to restore the Unity of the Country.

XVIII, Relative Advantages of the Eastern and Western Alliances,

XIX. The Growth of the Royal Power.

$\mathrm{XX}$. Increase of Foreign Infuences.

XXI. Resistance $t \cap$ Foreign Influences,

XXII. The Power of Resistance of the Constitution.

382

XXIII. Causes and Effects of the spread of the Reformation in Hungary.

XXIV. Bocskay's Insurrection.

XXV. Political and Religious Differences during the Reign of Matthias II. (1608-I619). 


\section{TRANSLATORS' PREFACE.}

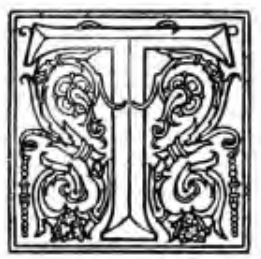

$\mathrm{HE}$ present volume is only part of the book projected by the author, dealing with the reasons for the preservation and development of Hungarian constitutional liberty. It treats of the period from the entry of the Hungarians into the country now known as Hungary, down to the end of the reign of Matthias II., that is to say, from 896 to 1619 A.I).

As English readers may not be altogether familiar with the course of Hungarian history, we have compiled a short list of dates of the most important events. It may also be desirable to say a few words about the noble class in Hungary, as that class differed greatly from the English nobility. In Hungary all the nembers of the clans that took part in the Conquest, and their descendants, were styled nemes, noble, and their class alone was endowed with full political rights. In course of time others, who had displayed great military or other talents, might also rise to the ranks of the nobility. Politically speaking the nobles were the nation. At lirst all the nobles were equal, and attempts were frequently made to maintain this equality. No distinguishing titles were used by the 
nobles (with two exceptions) until after 1.520, their family name being their sole distinction. Mll had the right to attend the Diet, which was at first merely a mass meeting of all who were endowed with full political rights. In time, however, differences arose; some nobles grew more wealthy and powerful than others, and the noble class became divided into the class of the greater nobles or magnates (barones et magnates), and that of the lesser nobles or gentry (nobiles). In addition there were the prelates of the church (domini praelati). The use of titles became customary in the time of the Habsburgs. Is the law of primogeniture has never prevailed in Hungary, the rights of a noble (including his title) descended to all his sons.

Our best thanks are due to Sir Courtenay llbert, K.C.S.I., for kindly reading through the M.S. and checking any references to English constitutional history.

C. IRTHUR AND ILONA GINEVER. 


\section{LIST OF DATES.}

889. - Krpád elected leader by the tribes.

896. - The Hungarians settle in their present home.

997.--St. Stephen elected Duke of Hungary.

1001.-St. Stephen embraces Christianity and is crowned king.

1222. - The charter known as the Golden Bull issued.

1241-2.-Invasion of the Tartars.

1301.-Extinction of the Arpád dynasty.

1308.-Ascent of the Angevins,

1342.-Coronation of Louis the Great (died 1382).

1366. - First 1 ar against the Turks.

1428-56.- Hunyadi's 1 ars against the 'Turks.

1458.-Election of Matthias Corvinus.

1478.-Peace of Olmütz.

1490.-Death of Matthias Corvinus.

1490-1516.-The Jagello dinasty.

1526.-Disalstrous battle of Moháes.

1527,-Ferdinand Habsburg crowned and the country split into two parts.

1538. - Peace of Nagyvárad.

1540.-Death of John, the last national king of Hungary.

1551.-Death of Martinuzzi.

1571.- Stephen Bithory elected Duke of Transylvania.

1605.-Bocskay elected Duke of Transylvania.

1608.-Coronation of Matthias II. (died 1619).

1613.-Gabriel Bethlen elected Duke of Transylvania

(died 1629). 

PART I.

The Creation of

the Hungarian

State. 



\section{THE TIME OF THE ÁRPÁDS.}

\section{CHAPTER I.}

\section{THE TIME OF THE ÁRPÁDS.}

It was favourable to Hungarian independence from the very first that the Hungarian invaders settled in a country which was rendered easy of defence by its physical formation, and that they had not to wrest it from the German peoples but from the still undeveloped Slavish races.

The new State was not in the way of the expanding European powers which were then dominant. The interests of European civilisation were closely linked with the fate of the German races, which, after accepting Latin culture, developed that civilisation in new directions.

The Hungarians were not powerful enough to arrest the German advance, and any attempt to do so would have brought defeat. Fortunately their geographical situation was such as to allow of German expansion without endangering Hungarian territory. The original inhabitants of the country were not related to the Germans, and they found the Hungarian rule less burdensome than that of the Slavs. The establishment of the Hungarians in their new home was not therefore opposed to the tendencies of the age. On the contrary, in the long run it actually furthered those tendencies. It was to this fortunate circumstance that the Hungarian nation owed the possibility of its development. But this development was brought about not merely by a lucky chance, but also by the exercise of great political sagacity. The Hungarians had the good sense to be content with the territory they had acquired, and to refrain from attempting any further conquests. Their roving spirit sometimes carried them far to the west, whence they brought home rich spoils, but they made no efforts to 
extend their borders. It was always characteristic of them, sanguine and ambitious though they were, that their natural impulses were kept well under control, and yielded to the dictates of prudence. The successes of some of their kings awoke desires which were out of harmony with the nation's true vocation, and were in no proportion to its strength. The Angevins in Italy, and Matthias, after his victories over the Germans, yearned for military adventures which could bring no enduring advantage to the nation. But the people always saw when their leaders were on the wrong track. Their instinct saved them from embarking on enterprises of mere conquest. While the Germans made the Italian aspirations of their emperors their own, and the English adopted the French projects of their kings, the pclicy of conquest never became a national policy in Hungary. There was, in fact, a somewhat exaggerated tendency in the opposite direction. The enlargement of a nation's territory is sometimes needful, even for purposes of defence, a truth which public opinion in Hungary has ignored even to the present day. Still, their ardent attachment to the soil, and their indifference to new territory has often proved advantageous to the Hungarians. This was especially the case at the commencement of their history. From the first they seemed to realise that they could defend themselves within their own borders, but that if they went beyond those borders they would fail. Where Arpád had settled down, there they must stay, or else be broken on the wheel of historical events. Within their own country lay their mission, while the West was reserved for other races. The history of the Turks shows how fortunate it was that the Hungarians did not seek to extend their dominions. The idea that where once they set their foot they must reign, was the curse of the Osmans. Had they settled down in one mass around Constantinople, within a region extending perhaps as far as the Balkans, and been satisfied with being masters of that territory which they were well able 


\section{THE TIME OF THE ÁRPÁDS.}

to defend, their fate would have been different, their enemies fewer, and their power would not have been absorbed in the task of repressing subjugated races, as it has been to the present day.

Fortunately, the Hungarians did not challenge their neighbours to a life and death struggle. Their numbers were not great, but by confining themselves to a moderate area they were enabled to maintain their control over the subjugated races, and were thus saved from the fate which befel the Huns and Avars. Their prudent policy kept them from overstraining their resources, and from coming into conflict with the predominant powers.

Another circumstance which made for peace was the conversion of the nation to Christianity, which did away with the gulf that had formerly separated Hungary from her neighbours.

But all these conditions merely made their existence possible without positively assuring it. The creation of Arpád and St. Stephen was lusty and promising, yet it was threatened by many dangers. The cross itself could not defend the Hungarians; only their sword and their brains could do that, and even so they could only hope to survive if the turn of events in the countries around them should prove favourable.

Had they not embraced Christianity they must soon have fallen, but their conversion was no guarantee of safety, for it was not only religion and culture which divided them from other nations. Racially also they stood isolated between two great peoples-the Germanic and the Slavish.

This circumstance alone was pregnant with danger. Their neighbours saw in them the successors of the Huns and the Avars, so that the Hungarians bore the burden not merely of their own deeds but of the actions of those races also. To the developing self-consciousness and culture of Western peoples, the Hungarians appeared as an Asiatic people, and an intruding barbarian element which had no proper place among them. 
During the Middle Ages race migrations were frequent. One warlike nation attacked another, vanquished it, and divided its territory among the conquerors, slaughtering the inhabitants if necessary. Of such a character, very largely, were the Norman conquests in England, in Naples, and in Sicily, and the conquests of the Crusaders in Constantinople, and in the same way the Germanic races gradually pushed the Slavish races towards the north-east. The vigour and love of action of the young nations, the restlessness surviving from nomadic times, the universality of warlike occupations, and the roughness of the age, all made the existence of the weaker insecure. The Hungarians were specially liable to attack, because their neighbours to the east were still nomadic. They had blocked up the path which had always served as a highway for the Asiatic races, and along which they themselves had travelled, and had wedged themselves between the civilised christian West and the wild pagan East. The Western races saw in them barbarians who should be extirpated, while their Eastern enemies' rage was aroused by their increasing civilisation. When they became entirely assimilated to the West, the East attacked them more frequently, and with increasing fury, and in defence of civilisation and Christianity they were constantly in danger. During the period, however, which immediately followed the foundation of the Hungarian State, it was chiefly from the West that danger threatened.

In that age two prevailing tendencies gave a character to history, a clinging to independence on the one hand, and a tendency to amalgamation on the other. The Roman Empire was invaded by the Germanic races whose predominant characteristic was their love of freedom and independence. Each nation desired to live for itself, and in accordance with its own laws and customs.

The fortune of war had brought them together, but they endeavoured to continue their separate existence, according to their own traditions, and without considering 


\section{THE TIME OF THE ÁRPÁDS.}

each other. This instinct was an important factor in that new world, and influenced largely the later development of Europe. To this spirit of individuality and selfassertiveness belonged the future, but only if it were to some extent limited by sufficient community of interest to bind these nations together. The new age and its civilisation could only be truly original and many-sided and attain the level which has been reached, if the new factors, while retaining their individual characteristics, were welded together into one civilisation having a common foundation.

This union was powerfully forwarded by two agencies. The struggle of those two agencies against the spirit of independence was the chief event of that age, and upon the issue of that struggle the character of the future depended.

One of those agencies was the Catholic religion. This had already achieved gigantic results when the Hungarians first appeared in Europe. It fused together the contending Latin and Germanic races into one mental whole. It penetrated the tribe, the family, and the individual mind. It regulated life in nearly all its aspects. It gave to races, different in their inclinations and aims, one common characteristic, which, while serving as a bond of union between them, separated them from the rest of the world.

Apart from this beneficent civilising work, the Church aimed at political power over Christendom. Nothing could be more natural than this. The Church may have gone too far in this direction, but the tendency was due to the consciousness of power which resulted from the greatness of her achievements.

Supreme over men's consciences, she felt she could be mistress of the world, and the temptation to endeavour to become so was too strong for her. It had important consequences for Europe that the clergy not only aimed at power in each country separately, but embraced the whole of Christendom in one grand conception, desiring to 
make of it one great theocratic empire. In the Church the Episcopal power became more and more evident, and the whole of this power was concentrated in the hands of the Pope. The Church being everywhere the most influential factor, as soon as its power was concentrated in one person, that person naturally became the first potentate in Europe.

But the Pope aimed higher still, for the memory of the Roman Empire gave rise to dreams of one great world-empire in his ambitious mind. The City of the Cæsars, with its world-conquering spirit, its grand memories and traditions, drove out Christian humility, and the Church, in opposition to its true aim, dreamed more and more of political supremacy. It was partly actual power, and partly the gigantic ambitions of the Roman world that developed the well-known pretensions of the Papacy.

In the meantime, the Roman Empire struggled towards the same ends. The Christian world needed protection from the Mohammedans and Pagans. The Pope himself was compelled to seek for aid against the Lombards. The Byzantine Empire was not strong enough for the task. It had no influence with the Western Latin-German world. A power was needed which had arisen from the elements of the new world, and which could defend the Church and the social order by force of arms. This task could be fulfilled by no other dynasty than the Carolingian, the dynasty which proved itself the strongest among the new powers, and which repulsed the assault of the Mohammedans.

On the other hand, the powerful Frankish king needed the divine sanction which could be conferred by the Pope alone, and by means of which a ruler was easily raised above all others. Hence was formed the alliance between the Pope and the Carolingians.

Charlemagne conquered nearly the whole of the Western Christian world. He was crowned Emperor by the Pope, and hence the Carolingians, as the political 


\section{THE TIME OF THE ÁRPÁDS.}

heads of Christendom, became supreme not only over all the States within their Empire, but also over those outside it. The conception of the Roman Empire suggested world-wide aims to the Emperor as well as to the Pope. Rome, even after her fall, exercised an enormous influence upon the whole of the known world. Up to the time of Napoleon, imperial conceptions were derived from Rome. In the boldest ambitions of Europe we recognise the spirit of the Cæsars. Their grand political achievement repeatedly lured the greatest powers to attempt at imitation. Its memory had an irresistible influence, specially upon the masters of Rome.

The influence of Pope and Emperor in the direction of union was just as necessary as those centrifugal forces which made for independence. A healthy development was only to be hoped for from a balance of these two conflicting tendencies, but, naturally, this balance could only be arrived at gradually, and as a result of great struggles. The conflicting principles which have been at work in shaping the history of nations have never sought to achieve merely such a measure of success as would be salutary. Each has aimed at absolute victory, and has tried to realise completely the ultimate consequences which must follow from it. This struggle of extremes has resulted in compromise. No success can be expected without such exaggerations, because it is these which awaken that fanatical devotion to a cause which calls forth effort. This inclination to exaggeration, however, often hinders progress, and gives rise to reaction. There is no principle, which, applied by itself, would not prove fatal in its logical consequences.

That age of turmoil which we call the Middle Ages was threatened by the exaggeration of contending parties. Two parties fought for supremacy, both of them indispensable, and yet the victory of either would have endangered the welfare of Europe.

Hungary's fate was profoundly affected by that great historical struggle. The danger which threatened her 
arose from the fact that in the German-Latin world the centripetal forces got the upper hand, and began to limit the independence of the constituent peoples. The two supreme rulers of the Christian world, closely bound together, began to mould Europe into something resembling the old Roman Empire, and this threatened to swallow up Hungary. The purpose of the combined effort was to establish the supremacy of one religion, one Pope, and one Empire, over the whole of Europe.

The power wielded by those two dominant potentates, Pope and Emperor, was incalculable. The greatest moral power that had ever existed in Europe, in alliance with the greatest military power, threatened the development of the free States. It was difficult to withstand their attack.

The interdict of the Pope diminished self-confidence and paralysed self-defence, while the great material power of the Emperor could easily finish the work so begun. The slightest check was regarded by the Christian soldiers as God's judgment, and this completely terrorised men's minds, and broke down all resistance. The conqueror's success was sanctified by the Pope's blessing. Men hardly dared to maintain that stubborn and prolonged resistance without which the weak cannot succeed against the strong, when they knew they were drawing on themselves eternal punishment by resistance, while repentance and surrender assured for them the forgiveness of their sins. The Middle Ages furnish numerous examples showing that these intellectual factors have often given even to a weaker force victory over forces materially much stronger. How much more could they achieve when backed by the most redoubtable military power of the age.

When the Hungarians entered Europe, Charlemagne's great Empire had already been divided, but Germany had risen again to power. The political situation, and the ideas of the Carolingians were inherited by kings of Saxon origin. 


\section{THE TIME OF THE ÁRPÁDS.}

It was a bad omen for the Hungarians that the rise of this powerful dynasty was due to the necessity for vigorous defence against the Hungarians. The new Empire was not so powerful as that of Charlemagne, yet it had considerable authority. It was the first power in Europe, and it was more dangerous to the Hungarians than the former Empire, because it was nearer to their frontiers. Through this geographical situation it could have annihilated the Hungarians, even if it could not have realised its plan of a world-empire, and could only have achieved so much as the subjugation of its neighbours. In the time of the Ottos the power of the Emperors was greater than that of the Popes, and the former protected the latter. In the election of Popes, their word was decisive. It is true that Pope Sylvester II. gave the Crown of Hungary to St. Stephen, but only with the Emperor's consent. He could not have acted otherwise, for he owed his dignity to Otto III., and was the Emperor's creature.

From this mutual understanding the two worldrulers, but especially the Emperor, gained great power. It was at this time that Bohemia and Poland were obliged to recognise his supremacy. Could the Hungarians avoid this fate?

It seemed impossible. While Stephen, the wise king, lived, the danger was not so imminent, but in the years following his death it grew threatening, and gave rise to a crisis which destroyed for some time the independence of the Crown, and might easily have annihilated it for ever.

The alliance of Pope and Emperor was certain to bring a conflict with Hungary, their next neighbour. Chance, indeed, played a decisive part in determining when the conflict should come. Its phases were determined by individuals, and by unforeseen circumstances, but the conflicting conceptions and tendencies were bound to precipitate a struggle sooner or later. St. Stephen's conception of an independent Hungarian State, and the 
Emperor's determination to wield supreme power could not be reconciled. The struggle began when the Emperor first had an opportunity of interfering in Hungarian affairs. When the Hungarians expelled King Peter, and he appealed to the Germans for protection, the conflict was inevitable. Henry III. did not miss the opportunity of extending his sway to Hungary. Had he acted differently he would have been unfaithful to the ideas inherited from Charlemagne and Otto the Great. He acted in accordance with his position, and with the traditions which pointed out the German Emperor as the head of the Christian world when he employed armed force to decide the fate of the neighbouring kingdom. He acted on the lines of his inherited policy also, by taking the part of Peter, an Italian, who seemed to be a more trustworthy support of western civilisation and western religion than Aba, a descendant of Arpád, and a thorough Hungarian. It was also natural that the Pope should support the Emperor in the action he took. The Pope's general policy was to side with the Emperor, and apart from this, their aims were the same in this instance. German supremacy over the Hungarians, whose Christianity was as yet somewhat uncertain, was a matter of common interest to then. German weapons and Papal curse weighed heavily upon the Hungarians. German warriors saw the hand of God in the great thunderstorm which arose suddenly during the battle of Ménfo, and discomfited their excommunicated foes, and from this simple natural phenomenon the Germans gained new strength for the continuation of the conflict. It is doubtful whether the attitude of the Church had not to some extent weakened the union of the Hungarians. Though, perhaps, not many, yet some certainly, feared the wrath of the Holy Father.

Yet the final result of the contest was, after all, victory for the cause of Hungarian independence. The struggle was carried on between varying combinations, and under changing leadership, until Germany gave up her plan, 


\section{THE TIME OF THE ÁRPÁDS.}

abandoned Salamon, whom she had patronised, and never again interfered with Hungary's independence.

What accounts for this fortunate result? What enabled young Hungary to brave the greatest European powers? The danger had been very great. The nation lived through a critical time. The battle of Ménfö, in consequence of which Henry III. became feudal lord of Hungary, and the Hungarian Crown lost its independence, might have proved a mournful day in Hungary's history, like the days which saw the battles at Mohi plain and at Mohács. But the great difference between these two battles and Ménfö, is that at Ménfö the enemy was not less but more civilised.

The victory of the Germans was likely to be fruitful in good from the point of view of civilisation, but the country's independence was the more endangered. Their higher culture might have made the relation of Hungary to Germany more constant, and might have made the country resigned to that relation, which was impossible in the case of Tartar or Turkish rule. But it was also to be feared that reaction against the aggressive action of the foreigners might endanger the recently accepted Christianity, for it was natural that the people should connect the new religion with foreign rule. The instinct of independence favoured those who were yearning for the old régime. Those who fought against the West and the leaders of Christendom, had to reckon with this tendency, and to look for support to the spirit of Paganism, if they wished to conquer. And this is what actually happened. Paganism revived in all its strength when the nation revolted a second time against Peter, resolved to get rid of a king imposed on it by the German Emperor and the Pope.

If this tendency had gained the upper hand, St. Stephen's whole work would have been undone, and the nation's progress, and its very existence, would have come to an end.

A future was only possible for Hungary as a constitu- 


\section{DEVELOPMENT OF HUNGARIAN LIBERTY.}

ent part of Christendom, but St. Stephen had intended it to be an independent factor. At that time it seemed as if this policy was an impracticable one, and that the Hungarians must either fall beneath German supremacy, or become Pagan again. The leading Hungarians recognised the danger of Paganism, and they clung to Christianity, not so much from devotion to it as from motives of policy. They tolerated the ancient religion while it was in the ascendant, but as soon as they became masters of the situation, they restored the new religion. They did not yield to the spirit of reaction, but clung tenaciously to the policy of their great predecessor.

It was due to a number of circumstances, great and small, that the Hungarians were able to resist the Germans. It is so with every important result. This is usually attributed to some great man, and great men undoubtedly exercise a decisive influence over their age, but there are in addition the general circumstances which are conditions of even the strongest individual's success, and which determine the direction of events. It is chiefly these circumstances which here demand attention. Of the events taken singly, and the part played by individuals, it is only necessary to say that the most decisive event was the death of the gifted German Emperor, Henry III., just when he had found in his son-in-law, Salamon, a candidate with claims upon the Hungarian Crown, who was inclined to subject Hungary to the feudal supremacy of Germany. After Henry's death Henry IV. mounted the throne in his childhood, and the importance of this event was augmented by the circumstance that at the same time the national cause in Hungary had gained two popular champions in Géza and Ladislas, who were called to the task of saving St. Stephen's work.

It was the great talent of Henry III. which had turned the scale against the Hungarians during his lifetime, and this double change made the situation favourable to Hungarian independence.

Among the conditions which made self-defence and 


\section{THE TIME OF THE ÁRPÁDS.}

ultimate victory possible for the Hungarians were their warlike qualities, and the tactics they pursued of tiring the enemy, starving them, luring them into the innermost parts of the country, and without ever coming to a great decisive battle, yet proving to the Germans by means of many small engagements that it was a difficult enterprise to conquer Hungary. It was also favourable to a strong resistance that Christianity had affected only a part of the nation, and not the whole of it, so that the Pope's word had no weight with most of the people. All these circumstances, however, cannot by themselves account for Hungary's final success. They enable us to understand that the struggle must have been a long and arduous one, and that it was not easy to bend the Hungarians beneath a foreign yoke, yet they were not invincible. Peter and Salamon, with all the influence of their royal dignity, were on the side of the Germans. King Andrew himself, who had been raised to the throne by the national party, was ready to recognise Henry's supremacy in order to assure the throne to his son, Salamon. Hungary passed critical days. Father and son, brother and brother, contended with one another. Christianity and Paganism, the central authority of the State and the independence of the people, the constitution and royal rights, private fortunes and the public purse, all were struggling for supremacy.

Then, too, the German Empire was more powerful than Hungary. It was greater in size, in population, in wealth, and in culture. The valour of her warriors was not less than that of the Hungarians. During the reign of Henry III. all this power was at the disposal of the Emperor.

As a matter of fact, it was not entirely the arms of the Hungarians which decided the issue of the contest.

Throughout the war the Germans were always the aggressors; the Hungarians never invaded German territory, and though they often repulsed the German armies with heavy loss, yet their victories were not so 


\section{DEVELOPMENT OF HUNGARIAN LIBERTY.}

crushing as to frighten that proud nation, and compel them to abandon their warlike projects, and give their policy a new direction.

The long struggle was not terminated by any one decisive event, but gradually died out. After an abortive invasion, Henry IV. abandoned his pretensions to the country of his brother-in-law, Salamon, because his attention and strength were claimed by new and entirely different problems. The alliance upon which his father's power had depended was dissolved, and the great struggle began between Pope and Emperor, lasting concord between whom must have proved fatal to Hungary.

History had reached one of its great crises. The split had to come sooner or later, but it was Hungary's good fortune that it tarried no longer but came just when the Emperor was at war with the Hungarians. If it had not happened then, and if Hungary's struggle with the West had lasted much longer, her whole history might have been different. St. Ladislas and Kálmán, who brought to a conclusion the work of consolidation, and extended their power towards the East and the South, would have had to spend all their strength in defence.

That Pope and Emperor should come into conflict with one another was inevitable. The two powers could only remain in unison if one of them succeeded in subordinating the other. This subjection was only likely to last if either the Empire assured for itself the right of electing the Pope, or the Pope acquired the right to dispose of the Imperial Crown. Till then, the concord of the two had been due to the circumstance that the election of the Popes was controlled by the Emperors. Henry III. during the years when he was striving for dominion over Hungary, acquired the right of speaking the decisive word in the Papal elections. Had this rule remained valid, vast prospects would have opened out before the Emperor, but the whole tendency of the times was against such a state of affairs. The progress of 


\section{THE TIME OF THE ÁRPÁDS.}

Europe demanded the independent development of its parts.

The formation of one vast central power, which would have united the spiritual influence of the Pope over the whole of Christendom, with the material power of Germany and Italy, could never have been the final phase of development. The safety of all the other Powers in Europe would have been in danger. Moreover, the German Empire had within it the germs of its own decay. It had become an anachronism. It was based upon a conception which was the natural product of a bygone age, but was not in accord with the spirit of the eleventh century. The idea of one Emperor, one Pope, and one religion, was derived from the times when the fate of Christendom depended upon the fate of one Empire, and this was ruled by one monarch, the Roman Emperor. When this idea was revived in the days of Charlemagne, the state of the world somewhat resembled the ancient conditions, and the restoration of the ancient Roman Empire seemed practicable. But when, during the following centuries, there was a strong and steady development in the direction of the formation of several independent groups within the Christian community, and against the creation of one great empire, and when the independence of France, England, and Hungary had been established, the foundation on which the proud conception of one great world-empire had been based, entirely vanished. The clain of the Pope that he uas God's representative on earth, and that by divine authority he regulated earthly affairs in accordance with heavenly principles, was inconsistent with his dependence on some earthly monarch. As soon as this earthly power was not the only one, the position of the Papacy became more endurable. If the Pope remained subject to the Emperor, he might indeed be an Italo-German patriarch, but by no means the head of all Christendom. The Church could only be supreme over independent States if she herself were independent. A great conflict 


\section{DEVELOPMENT OF HUNGARIAN LIBERTY.}

was, therefore, impending, and it only needed the man who, having a sufficiently exalted conception of his divine authority, should dare to employ to the full the vast power at his disposal.

Such a man was Gregory VII. His fanatical enthusiasm for the divine right of the Papacy, and his keen political insight, were fully equal to the situation. The combat which ensued was not fought with spiritual weapons only.

Fanning the newly-risen desire for independence in Italy, and in alliance with the malcontents in Germany, the Pope was able to bring material weapons into the war as well, and through this the German arms were diverted from Hungary. The battle of Mogyoród, which put an end to the reign of the Germans' ally, Salamon, was fought in 1074. Gregory had become Pope in 1073, and he excommunicated Henry IV. in 1076. Thus, the great struggle began just at the moment when a new effort was called for on the part of the Emperor to reestablish his supremacy over Hungary. This effort could not be made because of the conflict with the Pope, and so the war with Hungary ended.

Had the efforts of the Papacy been entirely successful the old quarrel would have arisen in a new form.

The ambition of the Pope was not satisfied by his own emancipation. He desired to emancipate the whole Church from the worldly power, and place it entirely under his own control. The great influence thus gained would enable him to gain political as well as ecclesiastical supremacy.

Since the election of the Pope had become the right of the College of Cardinals, the Papacy had become independent, and the patronage of the Emperor had ceased. It was now desired to secure the emancipation of the whole of the clergy from the secular power by means of celibacy, and by depriving monarchs of the right of investiture of bishops. 


\section{THE TIME OF THE ÁRPÁDS.}

In this way the Church was to be made independent of kings, and free from worldly duties, and as the chief judge of good and evil, as the master of human thought and action, as the supreme authority to command and to forbid, was to rise high above kings and emperors, and become the ruler of States and peoples. Above her was no judge, save God alone, while she stood above all and judged all. She had the right to dispense people from their vows and their loyalty, she could dethrone monarchs and dispose of crowns and territories. The Emperor must be her chief servant, who lent his arms and fought to subdue her foes. To the immense spiritual influence of the Church the Emperor added material force. This omnipotence was made possible by the fanatically religious temper of the age, and several times it seemed as if the Popes would attain their aim. The sons of Henry IV. abandoned their excommunicated father one by one, and Henry V. did homage to the Pope in order to assure his inheritance. Frederick II. was raised to the throne by Innocent III., the worthy successor of Gregory VII. Fortunately, however, for the Hungarians, and it might be added, fortunately for the whole of humanitv, these were but transitory phenomena. Henry V. himself, and Frederick II., became bitter enemies of the Papacy. At the cost of vast struggles, the Empire maintained its independence. It did not become a satellite of the Papacy, but pursued its own course and helped to maintain the world's equilibrium. This was the case at least until the death of Frederick II. in 1250 . Throughout that long struggle, lasting nearly two centuries, neither Pope nor Emperor succeeded in subduing the other, and to this fact was due the balance of power in Europe. Even in union, Pope and Emperor had not been able to dominate entirely over the other constituents of Europe, and directly they came into conflict with one another, the centripetal forces ceased to be sources of danger in general and to the Hungarians in particular. So long as the two parties were at strife, Hungary passed a time of comparative security. 


\section{DEVELOPMENT OF HUNGARIAN LIBERTY.}

The wise policy of the lings of Xrpád's line largely contributed to this result. They were careful never to take any part in the wars of their western neighbours, but remained neutral. Their sympathies inclined towards the Pope, as was natural in view of their past history and their interests, but they never became the Pope's tools. 'They never pursued such aims as were out of proportion to the nation's strength, and would bring them into conflict with the western nations, but followed a real national policy. King Ladislas and King Kálmán, freed from the danger of absorption on the west and holding themselves aloof from western affairs, were able to devote their strength to the task of consolidation. They and their successors extended the borders of Hungary southward and eastward, and this remained the policy of succeeding Xrpád Kings, and it was the only wise policy. It was fortunate that Hungary was then at peace with the west, for there arose new dangers which, had they occurred simultaneously with danger from the west, might have proved fatal.

The expansion of Iungary in the direction of the Balkan Peninsula brought the country into conflict with the ruler of Constantinople. When Hungary's king happened to be a minor, or when the country was weakened by some internal conflict, the Greek Emperor Manuel made a skilful use of the situation and gained so much importance that he claimed the part formerly played by Henry III. Had Frederick Barbarossa turned his arms against Hungary as he desired to do, for the old designs lived on in the hearts of the German Emperors, Hungary could hardly have maintained her independence. At that time Fredericli was on fairly good terms with the Pope, and it is characteristic that at such a moment his thoughts should turn towards Hungary. His position, however, was not sufficiently assured to allow of his carrying out his plans. The old strife with the Pope was rekindled, and Hungary was left alone with her southern adversary.

The Byzantine Empire was never strong enough to conquer Hungary. Under the eminent Emperor Manuel 


\section{THE TIME OF THE ÁRPÁDS.}

Byzantium was indeed a danger to Hungary, especially when that country was ruled by weak monarchs, but it never succeeded in establishing any permanent supremacy. Its efforts had not been prepared for by that effective influence upon Hungarian institutions which lent strength to German efforts. For Hungary whose civilisation was based on German institutions and German conceptions, the German Emperor was a much more dangerous enemy than an Eastern ruler. All the missionaries, knights and settlers from the west were natural supporters of the Emperor's claims, while the Greek ruler had no confederates in Hungary. Hence, the powerful arm of Béla III. easily delivered Hungary from that danger, and moreover, after the death of Manuel, the tottering Byzantine Empire disappeared from the ranks of formidable powers. Hungarian independence, resulting from the proportions in which the various European powers stood to one another, gained a fresh impetus, and even weak kings and internal dissensions were not able to destroy it.

Then occurred that disastrous event which destroyed at one blow the achievements of centuries-the invasion of the Tartars in the year 1241. It was due to Hungary's geographical situation that this disaster overtook her. Living on the boundary of the civilised world, the nation has always been exposed to barbaric invasions. The terrible defeat which Hungary suffered was partly due to the imperfect tactics of king and leaders, and to the panic caused everywhere by the inhuman conduct of the Tartar hordes, and partly to the great military skill of the Tartar Khan and the vast numbers and excellent quality of his army. To this it must be added that the chief pillars of Christianity, the Pope and the Emperor, being at war with one another, could send no troops into Hungary. This circumstance, which at other times was favourable to Hungary, on this occasion proved fatal. It was due to an internal crisis in the Tartar world that their invasion of Hungary passed away like a summer thunderstorm. 


\section{DEVELOPMENT OF HUNGARIAN LIBERTY.}

After two years of devastation and massacre the Tartars returned to their own land. Even if events at home had not recalled then it is hardly likely that they could have remained long in Hungary, for that country was too far from their own realm and too near the centre of the European world, and sooner or later Christian weapons must have broken their strength. Noreover, Hungary was too much civilised and consolidated to allow a prinuitive people like the Tartars to rule over it permanently. The Tartar peril proved a kind of test of Hungary's achievement. Defeat may have laid her low for a time, but it was not able to destroy the State and disintegrate the nation. The nation had grown strong enough to bear so great a blow and survive it. When the invasion was over, Hungary had cause to congratulate herself on the fact that the long strife between Pope and Emperor was still going on. The Emperor, Frederick II., would have liked to profit by Hungary's troubles. He demanded an oath of loyalty from the Hungarian King Béla IV., who had lost his country and fled. If the Pope, who interfered, had not dispensed Bella from his row, and if the Emperor had not had his hands full in Italy, Hungary would have had a difficult time again. As it was, however, the country soon regained its position in Europe and survived its misfortunes without having lost its independence.

Not for long, however, was Hungary to enjoy peace. Scarcely was the danger from the Tartars at an end when a new danger arose.

Béla IV. was still alive when, on the death of Frederick, the Pope gained a complete victory orer his adversary, the King of Rome, and the balance of power in Europe was thus destroyed. If the rivalry of the two powers had hitherto been Hungary's security, this new situation seemed fraught with danger. The Papacy sought worldly power as much as the Emperor did, and towards Hungary in particular the Pope felt he had a right to consider himself as a feudal lord, because it was from the Pope 


\section{THE TIME OF THE ÁRPÁDS.}

that St. Stephen had received his crown. He regarded Hungary as the fief of St. Peter, just as much as England and Naples. This theory was originated by Gregory VII., and it was now to be seen whether his successor, who had brought to a victorious issue the war begun by his great predecessor, would not put the theory into practice and bend Hungary to the service of foreign interests.

The attempt was made, but failed utterly, partly owing to the circumstances of the time, but partly because the passionate desire for independence which had strengthened the hands of the Hungarians in their warfare with the Emperor, now fortified them against the spiritual weapons of the Pope.

The circumstance which led to the Pope's interference was the death of $\mathrm{King}$ Ladislas IV. without leaving an heir to the throne.

The Pope refused to recognise the succession of Andrew III., and declared that to confer the crown was his right as feudal lord of Hungary and successor of him who had given St. Stephen his crown, and that he should dispcse of the country in accordance with his own interests. The Angevins had been introduced into Naples by Pope Clement IV. in order to expel the Hohenstaufen dynasty from South Italy. If the Pope could act similarly in Hungary it would help him greatly in the execution of his plans. He had no serious trouble to occupy his hands in other quarters; the Imperial crown was under his control; so he appeared to be acting in accordance with tradition and with his own interests in seeking to bind Hungary closely to himself. And there was much in the situation in Hungary which promised him success. For many years there had been much intercourse between Hungary and Rome, and the Pope continually exercised a kind of guardianship over Hungary which was accorded to him by the public opinion of the age.

The dissolute life of Ladislas IV., the part which he allowed the half-pagan Cumanians to play, the scandalous state of taxation, the injuries inflicted upon the clergy by 


\section{DIEVELOP.HENT OI HLNGARIAN LHBERTY.}

some of the powerful aristocrats, the entangled situation with regard to the filling of high ecclesiastical posts, and the many lawless doings which characterised that period, all gave an opportunity to the Pope to intervene, to give his orders and send his admonitions, partly by means of letters aud partly by legates. The Papal Gowernment, in fact, became the highest tribunal in Iungary. It became the custom lo grive power to the Church to vindicate laws by excommunicating those who infringed them. These excommunications became so frequent, and such a customary means of executing justice, that the priests complained that they were not able to comply with all the reguests to inflict them, and often they did not know the nature of the offence commitud.

The political situation in the country also served the Pope's interests. It was at that time that the nobles began their destructive work. Internal strife was their natural element, and the appearance of a rival claimant to the throne was a promising circumstance for them. They liked to fish in troubled watrers, so ther were by no means displeased that Andrew had an opponent. These were also some political interests which make for obedience to the Pope. The Tartars were still to be dreaded, and on the southern frontier there were some half-pagan, or at least heretic, races to be reckoned with. All this helped to make the Pope's support valuable. In spite of this, however, so long as the line of Xrpád lasted the danger was avoided. The bulk of the nation kept loyally to their elected king, Andrew 111 ., and it is a proof of the strength of their loyalty that the prestige of the Arpads eclipsed even that of St. Peter's chair. National sentiment and attachment to the dynasty were so powerful that not even the clergy could withstand their influence.

It is difficult to estimate the intensity of the nation's religious feeling, and its effect upon men's actions, but it is probable that although the people attached very great importance to the Pope's utterances, yet they never yielded him unconditional obedience. The Hungarians have 


\section{THE TIME OF THE ÁRPÁDS.}

never been so fanatical as the French or the Spaniards. They are not much given to abstract thinking, but concern themselves more with the manifold practical demands of life. They have shaped their conduct more with a view to the circumstances of this present life than to the teachings of the Church concerning the future life. it least, that is what the events of the thirteenth century appear to show. Hungary was, on the whole, on the side of the Pope, but not always, and never when political interests demanded some other policy. St. I,adislas became an ally of Ilenry IV. in his opposition to the Church. Even thuse kings who sided with liome would not make any sacrifice for her or do anything more than their interests allowed. The Hungarians played a comparatively small part in the Crusades, and they managed to remain at peatce eren with the pagan Cumanians. They never developed that zeal in the persecution of heretics which the lope expected of them. In spite of the most urgent reruleste to the cuntrary, they tolerated the Jews in the country and diel them no harm. They were on terms of much greater amity with the Greek Church than any other buropean nation was.

But in other respects the Chureh exercised a great influence over the people. It compelled the Crown to yield up some of its prerogatives in favour of the Church. There never oceured in Hungary that embittered strife between the sacred and the secular power which broke out in nearly every other European State. The nation saw to it that the Church should have its own prerogatives and possessions, though it cannot be said that these were always respected.

So long ats the Pope's claim was opposed by the prestige of the Xrpáds, his efforts were futile: but on the death of Andrew the situation changed and became more favourable to his plans. When there was no longer a lawful heir to the crown many of the people were willing to accept the Angevin Robert Charles, who was the Pope's candidate, and was backed by all the clergy. The opposite 
party, who were aware of the danger to the Crown's independence, were greatly weakened by the lack of a suitable candidate, for llencreslas and Otto had not proved satisfactory momarchs. All this was favourable to the Pope, yet after all he abandoned his claim to dispose of Hungary's crown. Ile: was content that the nation, anxious to put an end to the strifr, should elect the l'ope's candidate without reougnising the Pope's right to nominate him, and le fell in with the country's decision to pronounce the Pope's declatration invalid and his candidate's coronation null and void. Robert Charles became king, but not as a vassal of the Pope, who abandoned his puppose of creating a second Naples in Hungary. What led him to adept this attitude? Mistory records a dramatic scene at the Parliament held at Rakos, and tells us how skilfully Cardinal Contili, the l'apal legate, turned his speech when he saw how indignant the II at his declaration that they could only obtain a king from the Pope. Alarmed at their anger, the Cardinal altered his words so as to mean that a king lawfully elected in Hungary should be confirmed in his dignity by the Pope. But this skilful adaptation was not brought about solely hy the behaviour of the I I nngarians; the general situation in Europe had a great deal to do with it.

During the period from the year 1290, when the Pope desired to give St. Stephen's crown to the Angevins, to 1306, when Gentili had to rest satisfied with the accomplishment of his practical aim, the Pope's situation in Europe had greatly changed. It is true that he had 1. nculshed the Emperor, but his victory did not yield him the fruit he had expected. In order to realise his ideal of a world-empire he needed the help of a power strong enough and obedient enough to enable him to crush all opposition. Sometimes he was able to enlist the aid of various powers, and sometimes the Christian community took up arms in a cause indicated by the Pope. "Thousands, in fact such hosts as Europe never saw since the time of the migration of peoples until the epoch of general 


\section{THE TIME OF THE ÁRPÁDS.}

conscription, accepted the symbol of the Cross, but the Pope was rarely able to make use of this power for his own political aims. If some knights, specially devoted to the Pope, were ready to draw the sword at his every command, still the nations and their monarchs were only prepared to carry his excommunications into effect when it served their own political interests. This was fortunate for Europe, and saved it from a one-sided theocracy. The spirit of scepticism was still weak, and religion reigned supreme over men's intellects. The priests were revered as sages, and the only knowledge highly estemed was that drawn from the Bible. Men tried to explain the universe and all the phenomena of nature by means of this une book. At such a time cherical infuence could only be counterbalanced by egotism, which led men to struggle for worldly advantages, and heedless of what the spirit of the age demanded of them or of the conditions of eternal bliss, go their own way without hesitation, or by that idealism which inflamed the hearts of all who wished to guard their country's interests and the welfare of those entrusted to their care, and which steeled them even against spiritual powers. Such men could not endure the thought that the purest feelings of their heart were contrary to right and that the law which outraged their consciences was of divine origin-that it was their duty towards God to do what the most sacred interests of their nation forbade. Only those powerful motives were able to limit the power of the Church. All that was in later times achieved by scepticism, agnosticism and enlightenment, was accomplished as far as might be by the political spirit. This was so powerful that the Pope had to reckon with it, and to try to enlist a reliable ally strong enough to break down all resistance. In his war against the Emperor he had been able to group around himself great forces, otherwise his spiritual powers would not have saved him. The question now was whether he could enlist sufficient military power to enable him to carry out his plan of a world-empire. The Empire was apparently lying at 


\section{DEVELOHNENT OI: HUNGARIAN LIBERTY.}

his feet; could he bend this pester to his own uses and thus realise the old ideal-ahe twe swords griven by God in one hand, that of St. l'eter's stecessor? But the trend of events wats not in that direction. It was a political combination which had compuered the llohenstauten dynasty. The victory hat not been that of the chureh oser the world, and the trimmphant combination was not fatourable to the l'opre's buld schemes. The l'ope could not reckon on these allies in any attempt to extend his power. As soon as he endeavoured to assert his supremacy the community of interest which had formerly bound them to him, would have vanished. The Pope could only hope to suecered if lae could ohtatin control oser the troops of the ranguistaed Empire, but it might be called the irony of falle if it had not been the inevitable conseguence of the nature of the whole strugrele, that the snord of the worldly power was broken just as it came into the Pope's hand.

While the worldy power was strong it could not become the tool of eccle-iastical policy. To become subservient it must be broken, and then it was useless. The kings whe were raised to the throne by the l'ope after the fall of the Hohenstaufen dynasty were ready to obey him, hut were unable to help him to victury. It was soon recognised both by the Pope and hy public opinion in Ciemany, that the Empire had hecome ton weak. To strengthen it, Rudolf of Habsbure was raised to the throne. None of the parties cuncerned desired to revive in him the formerly powerfu! Emperor, they merely wished to allow him power enough to be a useful ally, without being able to pursue any independent aims or to oppress them. But it is always difficult to limit the development of a living force once set in motion. As soon as it is senerated it follows laws of its own without heeding the aims of those who called it into being. The Pope soon discovered this in the course of his relations with the Habsburgs.

They desired to be on friendly terms with the Papacy; 


\section{THE TIME OF THE ÁRPÁDS.}

did not endeavour to oppress it, and even abandoned some of their old rights, but they did not identify themselves with the Pope's world-wide policy. They had but one aim, the increase of the power of their family, and the assurance of its continuance. The demands of local German affairs and family interests became their leading motives, and these forbade their becoming retainers of the Pope.

These circumstances could not but exercise some influence upon the Hungarian situation also. Rudolf did not forward the Pope's plans in Hungary, but on the contrary tried to gain the throne for himself. In 1304 , the Pope asked Rudolf's son, Albert, to draw the sword on his behalf, but the request was not complied with. This in itself weakened the Pope, but at the same time he met with still greater failure in liance. After the fall of the Hohenstaufen dynasty he had made his power more felt by those States towards which he had displayed greater mildness during the struggrle. The Vatican never measured with the same measure. It bared its claims upon eternally valid principles, yet in practice it was opportunist. When fighting agationt the limperor, the Pope was mild towards France and llungary, but ats som as his hands were free he became stern. The French monarehy had grown more powertul in consequence of the Pope's support. In alliance with the middle classes and the Papacy, it had subdued the sreat feudal lords, and had restored, temporarily at least, the unity of the country. National self-consciousness had developed, and it found expression in the kingship. It is true that this early glory was transitory, but this happy period of French development coincided with the revival of Papal supremacy, and this proved fatal to Boniface VIll. The two conceptions-Nationalism and Roman supremacyhave never, and in no place, harmonised with one another. They were bound to clash in France, as formerly imperial ambitions had clashed with clerical aspirations. But while the Pope had found a natural support against imperial tendencies in Italy and centrifugat German 


\section{DEVELOPMENT OF HUNGARIAN LIBIERTY.}

elements, and in the neighbouring States which feared the Emperor, in this new strife he stood alone.

The privileged classes of France stood up for Philip IV. National feeling and the supremacy of non-clerical elements became so pronounced as to bring even the French Church into line against l'apal pretensions.

Surrounding States had no fear of this new movement.

The rrench king did not threaten the whole Christian world; it was only the Pope who could prove dangerous to the European equilibrium. Thus it was natural, but at the same time fatal to the Pope, that his cause was not espoused either by the German monarch or by any other ruler, and that in the vehemence of the contest his former friends were torn from his side. It became evident that without the support of a first-rate power, Papal dominion over Europe was impossible, and also that no such support was to be reckoned upon. The ultimate reason of all these failures was really the changed spirit of the times. Religion was still a powerful influence, though not so powerful as at the commencement of the Crusades, or at the time of the institution of the monastic and knightly orders.

The Church was too late with its victory. It was the everlasting merit of the German Emperors that they defended the rights of mankind during the period in which the Church wielded the most absolute sway orer men's minds.

Boniface VIII. was urged by his apparent triumph to the pretensions of Gregory VII. and Innocent III. But times had changed. The self-consciousness of the nations had grown strong. The Pope was able to break the imperial power just because of its excessive claims, but he was not able to replace it by his own power. Everyone supported the Pope against the arrogance of the Empire, but when he himself adopted the same policy he was abandoned by all, and met with resistance everywhere. The same instinct which assured 


\section{THE TIME OF THE ÁRPÁDS.}

to him strength against the Emperor opposed him when he tried to found a world-empire.

The fourteenth century had done with every form of imperialism, and it was impossible to place the Sti. under one common ruler. This lesson the Pope had to learn during his operations in Hungary. In 1296 Boniface commenced war with France. In 1303 he died, humiliated and broken in power. When Robert Charles was crowned in Hungary, the successor of Boniface endured further humiliations. The Pope had strained the cord too much, and it snapped when in Hungary he stood opposed to the same forces which had conquered him in France, and had shattered his hopes of a worn. kingdom. He grew careful, and was glad of a partial success.

In Hungary's struggle with the Pope there are many features of resemblance to her struggle with the Germans two hundred years before. In both cases she stood opposed to a tendency which threatened the equilibrium of Europe, and in both cases the final result was due to a change in the situation of the hostile power. It is worthy of remark that if in the eleventh century Hungary had become subject to Germany, and if the eastern part of Europe had recognised the supremacy of the Emperor, his influence in Rome would have been very different. But neither Henry III. nor Henry $\mathrm{IV}$. succeeded in consolidating his power in Hungary, and this was one of the reasons why Europe developed on lines different from those of the old Roman Empire, and the Emperor's pretensions became so entirely obsolete as to encourage in the minds of the clergy the thought of opposing them. In the tenth century the Saxon dynasty conquered the Hungarians once, and the glory of this victory to some extent revived imperial aims.

In the eleventh century, however, when imperial ideas soared high, their wings were broken by the dynasty's failure in Hungary. At the end of the thirteenth century, 


\section{DEVELOPMENTI OF HUNGARIAN LIBERTY.}

Ilungarian opposition was one of the reasons for the failure of the Pope's hegemony. If, after the death of ladislas IV., Hungary had been submissive to the Angevins, and had supported the Pope in Italy, as his vassal, Boniface would not so readily have fallen before the French arms.

But the great historical struggle in both cases was not decided entirely in Hungary or by Hungary, but in Italy, which was the erente of Europe at that time. The two epochs resembled each other in this respect, too, that the dangrer against which the Hungarians frought did not entirely cease. The pretensions of the Popes and the Emperors revived again and again. 'They pursued the Hungarians for several centuries. Ifter a long interval they revived in a different form, yet the results were similar in many respects.

When the llabburg limperors, standing at the head of the Catholic reation, waged war upon Hungary's prerogatives, the country was threatened by the same great historical tendency against which it had previously had (1) defend iterlf.

But of this more will be said later. We have now arrived at the threshold of a new epoch, so it will be well to sum up what has gone before.

It the outset, the sreatest danger threatening llungary was due to her being so utterly different in race and religion from her neighbours, to the small number of the Hungarians, and to the fact that in civilisation they were inferior to the nations round about them, who, aware of their own superiority, looked on the Hungarians with disdain, and regarded their independence as something offensive and dangerous. The contrast was so great that if the Hungarians had remained pagan their state could not have endured. Conversion to Christianity, however, softened this antagonism so far as to render their independent existence possible. Their geographical situation brought them near to the German races, but not among them, so that unendurable contrasts 


\section{THE TIME OF THE ÁRPÁDS.}

were avoided. But as they were strangers, and weaker than their neighbours, the decisive question was whether after having accepted the religion and civilisation of those about them they should fuse with them, or whether it would be possible to achirve a pustion of independence in the Christian world, and live among their neighbours with equa! rights. This problem was solved during the time of the Arpád kings. What had been a danger became a source of strenglh. Liecause the llungarians were strangers, others would not mix with them, but for the same reason they clung the mere powerfully to one

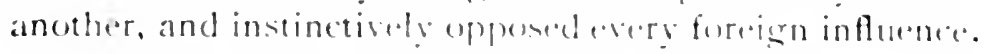

Differing so muell frem others, they fought against them with a desperate valuor lilie that of a tiger at bay. This was the source of that desire for independener which became so characteristic of them. From this, they gained strength to fight the German limperore. Thin was their bulwark against the boundlese ambitions of the Popes.

It was fortunate that for four cemturies there was no break in the ine of . Mrpid. This lener line uf . Yrpad rulers was the most important internal condition which influenced the deselopment of llungary. It assured to the nation a purely Hungarian monareh, and only witi such a monarch upen the throne coulel the people's passionate desire for independence be realined.

External conditions also faverured the existence of the nation, for during those centurie's the develepment of Europe was in the direction of the formation of independent States.

Out of the chaos following the downfall of the ancient Roman Empire, one great power tried to create a new world-empire. Fortunately for the Ilungarians, the ctfort failed, and the various races maintained their independence. The European order was no longer established on the basis of one all-embracing empire, but on that of at number of free and independent Staters, united only by the: 


\section{DEVELOP.MENT UI HU.GARIAN LIBERTY.}

ties of a common religrion and common civilisation. This made it possible that amid the threatening conflicts of those great powers which endeatoured to weld together the whole of Europe, llungary maintained an independent existence, and was able to establish her own freedom amid the wars for freedom of others, and as a defence of others' freedom. Ilungary owes her freedom to the eguilibrium of power in liurope, and her independenere became a factor and a support of that equilibrium.

The historical proessis reached its climax in the time of the Xrpads. When the lirst monarch of the Xrpad line was crowned, Pope Sylvester 11. and Emperor Otto 111. were in alliance, dispming of crowns and dominating the world. I few rears before the Xrpád line came to an end, one of the sreatt powers was lying at the feet of its former ally. The place of the Emperor was not exen filled up, and the German monarch was merely styled ling.

1 litte later, the other great power was also humiliated, and the two swords which had threatened Europe lost their edge for a considerable time.

When the Angevins mounted the throne, the balance of power had been established. The Ingevins and their dominions could enjoy the fruit of the work of former centuries. Hungary had been accepted as one of the European States, and her independence was the natural result of her internal strength. This happy state of affairs was largely due to the Xrpád kings. Inder their sway the country had passed its childhood and the critical years of adolescence. The problem of taking a place among the States of Europe as an independent factor had been solved.

The nation became so strong that in time its existence came to be regarded as necessary in the interest of Christendom and its civilisation, and of the balance of power in Europe. In consequence of the wise policy of her rulers, Hungary's strength did not interfere with the development of the western powers. On the contrary, 


\section{THE TIME OF THE ÁRPÁDS.}

the formation of a vigorous Christian State extended the frontiers of the civilised world, and increased the number of its workers and defenders by a valuable contingent.

In organising the chaotic district of Pannonia beneath their hegemony, the Hungarians had quieted a volcano always threatening eruption. In place of a dangerous chaos they created a thriving State, and made of it a strong bulwark of Christian civilisation. The purpose which Charlemagne wished to serve by founding the Ostmark was fulfilled more successfully by Hungary. She defended the west against the aggression of the east. Her weapons guaranteed peace for the work of progress. It was in Hungary that the 'Tartars exhausted their strength, and in later years still greater services were required of her. However, all this did not prevent her neighbours from occasionally attacking her. If weakenod by losses in defence of the post assigned to her by fate, it was always her western neighbours who endeavoured to profit by her temporary weakness. But, in spite of this, the fact that Hungary performed a function necessary for the progress of the west, became a source of strength to her.

Aggression commenced against Hungary never received the support on which it could have reckoned had it been directed against a harmful or dangerous element. It found no fuel in the common sentiment of Europe, but remained an isolated and selfish enterprise. In this fact and in the common interests of Christendom the nation found its defence.

The Hungarians proved good ground for the seed of western culture, and when the last Arpád king died, the race which had once alarmed the Christian community by its Asiatic habits had become civilised and wealthy, and had entered upon the path of peaceful industry.

It was due not only to the wise policy of her kings, but also to her people, that Hungary was able to take her place among civilised and progressive states. Her strength 


\section{DEVELOPMENT OF HUNGARIAN LIBERTY.}

lay not only in the national sentiment, but also in the ability of the people to receive western culture, and adapt it to their own temperament. But they never played a leading part in the adrance of civilisation. To some nations it is given to stand in the van of progress, and to do exactly the work which the age needs. Men of talent arise in great numbers, and circumstances being favourable, and opening up a career for such talents, they direct the productive strength of their nation and lead it to great results. This may last only for a few generations, yet long enough to constitute an important step in the nation's history-an epoch stamped with the names of the great men who have given it its character.

Perhaps the intensity of political life in Hungary hindered the setting of any distinctive national mark upon any epoch of human civilisation. Several Hungarians inscribed their names upon the roll of mankind's benefactors, and it was in these heroes that the race showed of what stuff it was made, but the nation's claim to be noteworthy must be chiefly based upon its political achievements.

Anyone who desires to write the history of Europe so far as regards accomplished results, must deal with Hungary's part from one point of riew only. He could hardly find finer examples of political judgment and the instinct for self-preservation than in the thousand years of Hungary's history .

The record of other nations may contain more brilliant epochs and display greater heights of glory than Hungary can boast of, but no nation surpasses her in the intensity and constancy of the national sentiment, and this sentiment never led to more strenuous activity and unflagging perseverance, and was never allied with keener political insight, and, in spite of an inflammable temperament, with quieter deliberation, than in Hungary.

Compared with her political achievements, Hungary's contribution to European culture is microscopic. One of her grandest future tasks will be to atone for this. 


\section{THE TIME OF THE ÁRPÁDS.}

Keeping pace with the progress of Western Europe, sensitive to the intellectual movements coming from without, and able to adapt foreign notions to her own needs in an organic way, Hungary became a useful member of the States of Christendom. This was the secret of her stability. Had the nation cut itself off from European civilisation as the Turks did, it would have remained a blemish to be removed. The Hungarians did not add much that was epoch-making to the intellectual treasures of the other nations, but by doing faithfully what lay in their power they were of use, for devoting as they did their particular strength to the common task, they added a new aspect to European civilisation, which owes its grand character just to its many-sidedness.

The race was able to develop its individuality. In those branches of intellectual activity in which to give up their originality would have meant their subjection to other nations, as in their language and literature, the Hungarians were able to retain their originality. Even where they borrowed from others, they did it in such a way as not to impair their mental independence. By these means they saved their political freedom. When the last Arpád king died they had already found the right way. They had become Europeans, yet they remained Hungarians. The basis of their civilisation being common to all Europe, the reasons for conflict were diminished and their strength for resistance augmented. 


\section{CHAPTER II.}

\section{THE TIME OF THE MIXED DYNASTIES.}

The accession of the Angerins to the throne coincided with an important turning-point of history. The powers which had previously claimed supremacy had to yield to the claims of the various States to independence. Not only had it been found impossible to subject the European family of nations to one central power, but the members of that family were individually unable to maintain an inner harmony. The great confederacies of to-day had not yet been formed. The kingly power was not yet strong enough to accomplish its great task of consolidating the nation and organising the State. Hungary was in advance of the agre, and became a centralised State at a time when in other countries the autonomy of fragmentary portions was the rule. The Arpád kings kept the country together with an iron hand, and when the Hungarians had to fight with the Empire and the Papacy, this circumstance made their rictory possible. When the aggressive strength of Pope and Emperor was exhausted it was the well-organised condition of the country which assured to it its position as an important power. The country increased in importance the more because while its government was becoming more and more centralised, the neighbouring German Empire was diminishing in strength.

The feudal system, adapting itself to the original inequality of the German races, had resulted in the creation of powerful feudatories in various parts of the country. The Emperor was not able to control them unless he himself possessed equal power, and even then, 


\section{TIHE TIME OF THE MIXED DINASTIES.}

contending with their jealousy, he had not strength enough left to endanger the safety of Hungary.

Neither had any of the various princes power equal to that of Hungary until towards the end of the Middle ages, when the Habsburgs became powerful. Whenever Hungary had an eminent king, the nation took a place among the great powers of Europe. This explains the glory of Louis and Matthias. A skilful hand made a wise use of the farourable situation in the country's interest. Several of Hungary's kings were monarchs of other countries also, so that some of them ruled over the largest dominions in Europe. Not seldom was the sceptre of Germany, Poland, and Bohemia in the same hand which held that of Hungary.

The country certainly had its misfortunes. Sonctimes it crossed swords with a nation stronger than itself, and suffered defeat, but even during the Turkish invasion its existence was never in danger for a moment. The distribution of power in Europe was favourable to Hungary, as was proved by the fact that the ties which bound Hungary to other powerful nations were never such as to be prejudicial to her freedom. If we consider what would have happened had the Krpád dynasty died out a century or so before it did, and if one of the powerful emperors-Henry III. or Frederick I. - had been elected to the Hungarian throne, and if we remember the great pressure which the Empire's relation to Hungary exerted upon it a few centuries later, only then do we realise how favourable the proportion of the powers to one another must have been at a time when the imperial crown of Sigismund was not able to diminish the lustre of the independent Hungarian Crown.

The country was then enjoying the time of its greatest security. As faithful stewards of the nation's interest, and in skilful use of a favourable situation, no subsequent monarch can be compared with the Xrpáds.

There were several eminent personalities among the later kings, and the part they played in Europe was more 


\section{DEVELOPMENT OF HUNGARIAN LIBERTY.}

striking than that w the Xrpads. They founded many valuable and enduring institutions, and during their reigns the country made great progress in culture and wealth, but their policy was not hased upon great and permanent llungarian interests as that of the great Xrpáds had been.

It cannot be denied that the Xrpids were Hungary's most truly national kings, not by birth only, for Matthias "as just as much IJungarian as they, but in their policy. The others, with Matthias among them, adopted a European policy. They endeavoured to win power and glory in the west while they romparatively neglected the east. Entangled in western problems, they did not direct sufficient attention to the region in which the real national question was whe decided, from whence the real dangers threatened, but where their power might have been deeply rooted. The true II Its invariable twofold principle has aver been to maintain peace, and, it pessible, an alliance with the west, or at the worst, to rematin on the defenaive if fighting were unavoidable, and to claim al leading part, and to attempt an extension of influence only towards the east, where Hungary represented the west and its cirilisation.

It stirs regret to think how different the course of Inngarian history might hare been if the kings of the mixed dynasties had taken this line. What prospects would have opened before the Hungarian kingdom if it had grouped aruund itself the Christian peoples of the east and had fought side by sidc with them in the passes of the Balkans for the defence of Europe, Christianity, and Hungary, and if the spirit of John Hunyadi had per. meated the whole age.

But we must not be unjust. Even if our greatest kings left the path of sound national policy, they wer. often led to do so by weighty reasons, and sometimes again they were influenced by pardonable ambition.

The chief trouble was that none of the foreign dynasties remained long in possession of the Hungarian crown. 


\section{THE TIME OF THE MIED DYNASTIES.}

The new dynasties brought with them their own interests, and these were all intermingled with western affairs. They were also hampered by the imaginary rights of neighbouring monarchs, which led to continual wars.

The Arpád line had so firmly established the power and independence of Hungary that their work endured for centuries, but the mixed dynasties could not achieve such a result as that. Had the later monarchs succeeded in averting the danger of a Turkish invasion, and in defending cirilisation in the Balkans, they could not only have consolidated the work of the . Yrpád kings, but could have developed it, and raised Hungary to a pinnacle of power slue had never before attained.

But the opposite of this happened, and Hungary fell upon evil days. From the zenith of splendour and power the country was precipitated to ruin. The glorious age of Matthias was followed by the mournful day of Mohács.

The fourteentl and fifteenth centuries were comparatively peaceful, but towards the end of the fifteenth century dark clouds gathered on the horizon. The sky became overcast, both in the east and in the west, but the chief danger lay in the east, where the Turkish power was increasing. In the neighbourhood of Hungary a warlike race had established itself, whose military power was directed by one will. At the word of one man hundreds of thousands of fanatics were ready to die. Their faith commanded them to fight, and the whole nation was well organised. Islam commenced its war with Christianity. First of all, Hungary was to be subdued, for Hungary blocket the invader's path. The conflict was inevitable, and could only be terminated by the exhaustion of one of the combatants.

Hungary had missed her most favourable opportunity of getting rid of her dangerous neighbour. When the nation was powerful, and governed by great kings, the Hungarians had occupied themselves with western problems, whereas they should have been guarding against the danger to themselves, which lay in the increase of 
Mussulman power. The Turkish invasion broke upon Hungary like a thunderstorm. At first, occasional flaslies announce its approach, then the thunder becomes louder, the whole sky is overtast, and at length the storm breaks out in all its fury. Just when the storm was at its highest it found a weak child upon the throne of Hungary, and in the nation itself, internal strife and constitutional change: the usual accompaniments of wealiness on the throne in the Middle iges.

That which had so often proved a lightning rod to defend the structure of the State from such storms, the steel sword of the Arpaids, was no longer in the service of the country. Hungary had a great jurist, but no statesmen; she had prerogatives but no well-equipped forces. In these circumstances she was doomed. It that critical epoch in her derelopment when the blow fell, she was called upon to resist the greatest military power of the day, made strong by fanaticism, and led by the talented Sultan Soliman.

Negligence brought its punishment. The country had not made sufficient efforts in the past, and had not seized the opportunities for bold initiative and offensive action.

Though the Hungarians had defended their frontiers on the occasion of previous attacks, they had not taken pains to utterly extirpate the danger. The Turks repeated their attacks until the farourable monent came. That moment came with the reign of an eminent Sultan coincided with a temporary weakness in Hungary, and this coincidence led to Hungary's downfall.

That the country should be utterly crushed by a single day's battle, however, and its strength so diminished that an alliance with some western state became essential to its very existence, was due to many circumstances.

Dangers were also threatening from the west, where powers were arising with which Hungary ought to have come to some understanding. Europe had reached such 


\section{THE TIME OF THE MIXED DYNASTIES.}

a point in its development that the weakened and broken Hungary had either to become subject to the east, or else to join her western neighbours. Hitherto the strength of Hungary had been her ability to organise a strong State, while in other countries local interests had benumbed the central power. This advantage had now begun to diminish. The fifteenth and sixteenth centuries were the era of State building. Countries larger and more populous than Hungary, with which she had only been able to keep on equal terms by reason of her powerful organisation, began to be consolidated. The trend of events was towards the increase of the kingly power. France was welded together: Spain became organised, and the strength of England became self-conscious. Hungary's neighbours, the Habsburgs, founded their great empire. European politics consisted in the marshalling of greater forces than before. If Hungary had not been destroyed at Mohács, and had continued her progress, she might have held her own in that great struggle, too. But the situation rapidly grew worse. As during the time of the Xrpáds, the nation had to fight for its independence against the strongest power in the world, and the most ambitious monarchs; so now, during the Turkish wars she was called upon to defend herself against her powerful western neighbour. But, after the sufferings and losses inflicted by the Turks, this task became impossible of accomplishment. After the defeat of Mohás, and with the Habsburgs threatening on the west, the country could only maintain its existence by an alliance with these neighbours.

The nation had been able to lift its head after the Tartar invasion because there had been peace with the west, but now this was no longer the case.

Rudolf, the founder of the Habsburg dynasty, desired Hungary for his son, and his successors laid claim to the crown.

'The Habsburgs endeavoured strenuously to possess themselves of Hungary, not temporarily, but as a per- 


\section{DEVEI,OPMENT OF HUNGARIAN LIBERTY.}

manent hereditary possession, as if they foresaw that Hungary was to play a great part in the history of their dynasty, and to become the foundation stone of their empire. Hungary was essential to European welfare. Her vocation lay in controlling the development of the east in accordance with the requirements of western civilisation. As soon as her people became unable to discharge this function her separate existence ceased to be to the interest of the civilised world, and it became necessary for some new power to arise to fill the gap caused by Hungary's downfall. The Habsburgs seized the opportunity. Their own interests and shadowy hereditary claims urged them to stretch out their hands to grasp the Hungarian crown. Only if she had been strong enough to fight both east and west at once, could Hungary have maintained her independence. Wedged in as she was between the leading Christian State and the powerful pagan realm, she became an object of desire to both. Situated as she was, she acted wisely in accepting the Habsburgs, though such a course brought its own dangers with it.

A new epoch in the country's history now opened, and the dangers which threatened her were different from any she had formerly encountered. To the old international struggle were added internal struggles to maintain the constitution. Everything depended upon the way in which the constitution would stand the test of the dangerous innovation. So far, the country had only to dread the foreign yoke, but now the Hungarians had cause to fear lest they should be merged in the other peoples over whom their monarch ruled, and the dignity of St. Stephen's crown be eclipsed by the greater glory of the imperial crown. The danger being new, a new kind of defence became necessary. While the fate of the country had formerly depended upon the chance of international conflicts, it now depended upon the relation to one another of the various factors of the nation itself. Hitherto, only the outer defences had to be looked to, but now the chief 


\section{THE TIME OF THE MIIED DYNASTIES.}

organ of the State itself threatened the nation's independence. Absolutism meant loss of separate statehood, and the maintenance of the constitution meant the preservation of independence.

When the Habsburgs ascended the Hungarian throne the power of the monarch was steadily increasing in every country of Europe, owing to many farouring circumstances. Everywhere this increase was at the cost of the constitution, and numerous conflicts arose where the kingly power met with an obstacle either in the nobility or in the constitution itself. This trend of events had an influence upon the conceptions formed by the Habsburgs of their rights and duties, and opened new paths for their policy.

Charles, the brother of the Hungarian king, was absolute ruler of Spain, and the most powerful monarch in Christendom. He raised the dynasty to greatness, and the Spanish idea that the king's will must be the nation's law, found its way into the mind of every member of it.

The power of the Habsburgs was immense. 'They disposed freely of the nation's money and soldiers, remoring these from the sphere of popular control. They had at command all the means which royalty can use to extend its influence, and could reckon on many of the sentimental motives which always strengthen the position of the monarch. Where could anyone be more sure of gratitude for fighting to restore the old frontiers of the country than in Hungary, which had been robbed by enemies of its faith and race, of that soil to which the Hungarians clung as to the very source of their life?

Where was the restoration of peace and order so urgently demanded as in a country where, during the Turkish invasions, so much of the fruit of years of peaceful work had been destroyed, and where men's family and fortune, and bare life itself stood in need of protection? The fatal day of Mohács made the nation look with different eyes upon freedom, and to see the necessity of a strong hand at the helm of the State. 


\section{DEVELOPAENT OF HUNGARIAN LIBERTY.}

Moreover, the Habsburgs, possessing vast military resources, naturally pursued their aim of creating a united empire without paying much consideration to the constitution of its various component States.

Simplicity of government and security against external foes required this, and hence it is easy to realise the magnitude of the danger which threatened Hungarian independence.

But just at the time when the constitution was threatened by the growing power of the monarch, and it was to be feared that a reaction would occur favourable to the king's aims, suddenly the constitution proved itself to be the bulwark of the nation's life.

It is necessary to trace the origin and development of that constitution, for only thus can we discover the explanation of its strength and weakness. Had it become in the course of time a part of the nation's very soul, or was it only a showy, but adventitious appendage, unable to perform any new services? This question takes us back to the earliest period of the nation's history, and brings us to the problem, the solution of which is the second purpose of this book.

Hitherto only the reasons for Hungary's survival as an independent State have been dealt with, and it was possible io treat them separately, because the form of government had not much to do with them. That the country remained a constitutional monarchy was not one of the circumstances which contributed to Hungary's independence. The general rule was, the stronger the monarch, the more secure the State's existence, but in Hungary, from the sixteenth century the situation was different. There, the freedom of the State was based upon the freedom enbodied in its constitution. The two kinds of freedom were bound up together, and became a common interest. Before dealing with that period, however, we must trace the development of the constitution up to the time of the battle of Mohács. 
PART II.

\section{The Development of the}

\section{Constitution.}





\section{SOURCES OF THE ROYAL POWER.}

\section{CHAPTER III.}

\section{SOURCES OF THE ROYAI, POWER.}

When the Hungarians first entered Europe they enjoyed very great freedom. The ruling power was divided between the elected chieftain, the leaders of the tribes, and the warriors, that is to say, all the free members of the nation.

Between ruler and people, reciprocal duties were settled by a contract, and if the ruler broke this contract he was liable to be called to account.

The nomadic peoples of that age could hardly have been anything but free. Everything contributed to this result. The prince or king was really an elected chief, who led to war those who were in other respects equal to himself. The spoils of war were equally divided as the deserts of all were equal, since victory was chiefly a matter of personal valour. No enterprise that was not embarked upon with the goodwill of all was likely to turn out well, so that all plans needed to be discussed by a council. If the ruler proved lacking in the qualities expected of him, or if he lost the nation's confidence, then the necessities of the people's one great pursuit-warfare,-demanded his deposition, and the election of another chief.

Weapons were accessible to all alike. To commence a war it was enough if there were sufficient men willing to unite for the purpose and obey a leader. To set in motion an army was not the privilege of the leader, as it afterwards became, nor did his position make his will paramount. It was impossible for him to compel obedience. His followers either yielded voluntary obedience, or became unmanageable. There was no separate army 
dependent upon the ruler among a people whose every man was trained to arms. The strength of the ruler lay in the confidence of his followers. A strong and permanent central authority, independent of the will of the nation, was not needed. The discipline indispensable in warfare was the interest of all, and the ruler who was fit for his post could always reckon on obedience. The people occupied a comparatively small territory, and they were not divided by conflicting local interests. The nation's chief was able to exercise a personal influence upon all, and no individual was strong enough to stand against the rest of the community. A strong and permanent central authority was, therefore, not necessary, even for the maintenance of unity. The primitive community therefore enjoyed a very free form of government-a freedom natural, and due to the circumstances of a nomadic people's life, but as soon as these conditions gave way to others, an altered form of government became inevitable. Most nations gradually lost their freedom, but the Hungarians managed to preserve much of it, though the form of it changed.

The Hungarian constitution can be traced back without a break to the freedom of nomadic times. When in the sixteenth and seventeenth centuries it was threatened by a grave crisis, it had become deeply rooted in the thought and feeling of the nation.

The one great circumstance which made this fortunate development possible was the early restriction of the people's freedom within reasonable bounds, so that centrifugal tendencies never became so pronounced as to threaten disruption, and to give rise to a reaction in favour of autocracy. The condition of affairs during the Middle Ages favoured the development of a kingly power strong enough to maintain the national unity side by side with a large measure of general freedom.

Before dealing with this question of the persistence of the people's liberty, it will be necessary to indicate the causes of the growth of the kingly authority. 
The constitution which met the needs of a nomadic people became unserviceable when larger States were formed.

As the armies settled down and spread over wide areas, the force which had held them together became impotent. Society was broken up and resolved into its constituent atoms. The personal influence which had maintained the organic unity of the warriors who lived near one another and kept up intercourse with each other, was not enough to bind together a nation which had ceased to be nomadic, and had become an agricultural people, and had mingled with the subjugated races. The old central authority could not meet the new requirements, and new institutions and a new constitution became necessary.

Progress has always been most assured when the agency which effects a necessary change can serve its own interests at the same time as the interests of all. The kingship was such an agency. It found its interest and its vocation in that which the nation most needed, and it commenced the great work of developing the tribal system into true state life.

During the great wars which opened up new countries to the barbarians at the time of the migration of peoples, the leader was generally surrounded with a halo. The conquest and settlement of the new territory wrapped him in glory. He gained still greater influence from the circumstance that in the Roman atmosphere the conception of a ruler became a new and greater one.

Two circumstances contributed to the leader's increased importance. The Christian Church was threatened with destruction by the pagan invasion, therefore she devoted all her strength to the task of converting the barbarians. In order to succeed in this task she endeavoured first to win over the leaders, for the conversion of the tribe usually followed. It thus became to the interest of the Church that the leader's dignity and 
authority should be increased, and so she exerted all her influence on his behalf.

The enormous success of Christianity thus meant strength to the monarch. This relation between Church and ruler led to the notion of kingship by the Grace of God. The blessing of the Church gave sanctity to the kingly authority, and the idea was encouraged that this authority had some higher origin than the people's will. The other circumstance which contributed to the exaltation of the monarch was the memory of the Roman Emperors, with the idea that they represented the nation, and that the public will was expressed in them.

But the transformed kingship was confronted with a colossal task, and in most cases the effort to found a strong State led to no permanent result. The new creation appeared to be founded on the sand, and the work of even great personalities speedily fell to pieces. The rivalry of the constituent parts nearly always nullified the central power, and the kingship, in spite of its theoretical greatness, became practically impotent in most countries. Even if certain rulers succeeded in establishing their authority, and subordinating the people to central control, yet in those States which were formed during the great migration of peoples, sooner or later there usually commenced a decadence.

Hungary was one of the few exceptions. She alone among European States maintained her unity from the moment of the conquest without any break, and within almost unaltered frontiers, while retaining much of her primitive character. After the conquest, in Hungary, as in Germany, the retention without any modification of the people's original liberty would soon have meant the dissolution of the State. As the various tribes scattered themselves over the conquered territory, the ancient and loose legal ties became insufficient to bind the nation together.

Personal intercourse became rare, and local interests grew in power. The districts which settlers made their 


\section{SOURCES OF THE ROYAL POWER.}

permanent home linked closely together those who dwelt within them, but at the same time separated them from the rest of the community. The ruler, on the other hand, represented the common interests of the whole nation. In Hungary, as in other countries, the monarch endeavoured to increase his power, and with the aid of the Church to add dignity to his office. St. Stephen adopted Charlemagne's conception, and copied the achievement of Charlemagne on a smaller scale, yet with more permanent results.

What St. Stephen built did not fall to pieces, but maintained itself, in spite of all those difficulties which in other countries brought similar creations to nought.

Charlemagne died in 814 , and his realm broke into three pieces in 843 . In 888 , instead of these three fragments we find seven. One of these, France proper, was subdivided into twenty-nine little states, almost independent of each other, and a century later, on the area of this kingdom, there were fifty-five petty sovereignties.

How was it that while the creation of Charlemagne proved transitory, the state founded by St. Stephen maintained its integrity?

It was impossible for the empire of Charlemagne to remain a whole, and its fate cannot be compared with that of Hungary. It was immense in area, and included very heterogeneous elements, while the various nationalities composing it all possessed the essential conditions of independent political existence, namely, a separate territory and the feeling of community based upon common traditions. Charlemagne's creation was a world-empire, whose vocation was but temporary. As soon as it had assured the triumph of Christianity in Central Europe its fate was sealed, and it was bound to fall to pieces. But the further dissolution of the parts formed in 843 has a different explanation.

This explanation is to be found in the general circumstances of the time, which tended to split the whole of Europe into small provinces, and almost everywhere 


\section{DEVELOPMENT OF HUNGARIAN LIBERTY.}

destroyed national unity. The means by which kings later on added to their dignity were not yet ready to their hand, and circumstances were unfarourable to centralisation, and made the governing of masses of people dwelling far from one another very difficult. The absence of means of communication, the undereloped state of commerce, and the primitive level of civilisation, were among the circumstances which prevented a feeling of community arising among the people, excepting those living close together. Only local interests gained prominence, and this diminished the influence of remoter interests. The nation came to have fewer common interests, and even those which remained were not clearly understood. All this made the king's task a very difficult one. Even the means he employed to safeguard his interests played into the hands of the local powers.

The officials appointed by the king emancipated themselves from his control, and usurped the rule over the province entrusted to then. Far from the centre their prosperity depended upon their establishing an understanding with the local powers. If they were able to strilie root in the locality, they had no reason to fear the king, while if they failed to do so, even the king was unable to aid them. They were compelled to rely upon themselves, and this encouraged a feeling of independence, so that it became almost impossible to control them.

Another circumstance contributed to the same result. The dignity and power of such officials depended upon their possession of land. The ling was obliged to give them estates and fortresses, or they would have been deroid of any power to execute the king's commands. But as soon as they gained these advantages it was to be feared that they would ally themselves with local interests, and thus strengthen the resistance to the king.

The possession of estates as an essential to the holding of office, in time altered the nature of that office.

The tendency of the estates to become hereditary. led to efforts to make the office also hereditary. 


\section{SOURCES OF THE ROYAL POWER.}

Where these efforts were successful, the whole system was destroyed, the central power was annihilated, and these local potentates became the real rulers of their territories.

If they succeeded in conciliating public opinion and in grouping around themselves the chief men of the district, they became masters of a much more united force than the king could command, and such a district lived a much more truly state life than the country itself as a whole.

Those whose task had been to organise and maintain armies for the king, themselves became the masters of such armies, and used them for their own purposes. The conditions of warfare in those days favoured this indepenclence of the monarch. Resistance was facilitated by the almost impregnable castles, which enabled a small force to withstand with ease a large army. In earlier times, when nomadic conditions prevailed, a small force coul 1 not thus resist a large one, nor could it in later times, when the newer weapons made it impossible.

Everything, therefore, tended to the splitting up of large states into small ones, each of which could be easily defended. Effective rule extended only so far as the sword could reach.

These circumstances were present in Hungary, as in other countries, yet they were not able to destroy the power of the king, nor to dissolve the unity which he represented.

Why was this? The explanation which first suggests itself is that since disruption occurred most frequently where feudalism prevailed, and as in Hungary this system never gained so firm a hold as in other countries, it was to this circumstance that Hungary's stability was owing. This explanation, however, is not the true one. It conflicts with the fact that Hungary gradually accepted feudalism, that in England it was just by means of a rigid feudal system that the crown maintained its authority, and also that in countries where this system 


\section{DEVELOPMENT OF HUNGARIAN LIBERTY.}

never established itself, disintegration became more and more thorough, as in Italy, where each town became an independent community, and in Scotland with its clans. The maintenance of the kingly authority in Hungary must, therefore, have had some deeper reason. Royalty depended for its strength upon the support it found in the common sentiment of the people.

Wise laws, good institutions, and the power of great individuals could not permanently counterbalance the harmful influence of a situation that was fundamentally wrong. The history of that age shows that where the kingship remained strong it was generally the case that the nation had been threatened either by external or by internal foes, so that all the people could not but see the need for some central authority.

Some very evident danger was needed in order to make a primitive people feel the necessity for unity. Thus, we may notice that in Norman England, a comparatively small army having invaded the country, the invaders, living in a state of perpetual strife with the original inhabitants, instinctively sought protection in a strong central authority. The Saxons were greatly embittered against the Norman nobility, who had usurped the rights of the Saxon franklins, in whom Saxon life had found its chief expression.

The danger which this hostility portended to the Norman supremacy made the Normans conscious of the need for union among themselves. The kings made a skilful use of the situation. Partly by promising protection to the Saxons and showing them favour, and partly by championing Norman interests, they managed to attach both parties to themselves. This led to the unity of the State, and made the maintenance of such unity possible.

In France the whole situation was different, and the development was different also. The Frankish tribes were so much more vigorous than the Gauls, who were long accustomed to subjugation, and than the scattered Roman 


\section{SOURCES OF THE ROYAL POWER.}

citizens, that their supremacy was never in danger. Neither were they threatened by any such external dangers as would make the Franks recognise the need of a central authority.

Charlemagne had averted external dangers. Since his time the Franks regarded themselves as the supreme power in Europe, and this assurance paved the way to decentralisation. The forces which made for union fell into the background, because they were regarded as superfluous, and disintegrating influences came to the fore. The institutions of Charlemagne were unable to counteract this tendency, and they themselves facilitated decentralisation. The feudal system which Charlemagne wished to make the basis of union, established the local potentates. It nourished, not the strength of the State, but the independence of the parts. The lines of cleavage coincided partly with racial distinctions, partly with geographical boundaries, and partly with the hereditary distribution of territory. The resulting division did not represent the victory of the national principle, for there were not so many tribes and nationalities in the country as the parts into which it was divided.

In Hungary, the king would not have been able to maintain his authority had not many reasons convinced the nation of the value of unity, and had not the citizens been so much afraid of anything that might weaken the State as to be willing to suffer some limitation of their liberty.

We have little positive information, but if we consider the situation of the Hungarians in Europe, and when we remember that predatory raids upon neighbouring countries had hardly ceased when the monarchy was set up, and that even in those primitive times the nation displayed remarkable political sagacity, we cannot doubt that the danger threatening their independence made the Hungarians realise that they must strengthen the central authority. Living among nations stronger than themselves, they found, like other nations similarly situated, 


\section{DEVELOPMENT OF HUNGARIAN IABERTY.}

that their very existence depended upon their unity. The Hungarians were, therefore, willing to limit their own individual freedom, and to assist their ruler in his task of maintaining order, at a time when other more civilised peoples scarcely felt the need of State organisation.

Recognising their common interest, the people were ready to abandon several of their privileges, white other more civilised races allowed their State to fall to pieces in order that they might enjoy greater freedom.

How was it that the Hungarians, a people of unbounded courage, who had never found obedience an easy matter, endured and faroured the king's supremacy at a time when popular sentiment was opposed to it in other countries?

The Hungarian race was not a member of that great dominant family amidst which it found itself. No tie of common religion linked it with its neighbours.

The Hungarians were without kindred in the new world which they had entered. We learn the opinion formed of them from the Chroniclers, who speak of them as though they were fiends and not human beings. Their racial type, their language and customs, became a barrite between them and their neighbours. Is it not natural, therefore, that the Hungarians felt something of the same antipathy towarks those round about them, and that their sense of isolation as a race strengthened the sentiment of community among themselves, and made them turn to one another for support as animals flock together when danger is near? If any of them, separated from their fellows, became subjugated by some other race, they suffered more than Gaul or Burgundian or Frank, who even in such a case fell among kindred tribes.

The danger which threatened the whole nation could not but be keenly appreciated by each individual. The forces at work here were not merely abstract ideas, the idealistic love of country, or mere sense of duty, but 


\section{SOURCES OF THE ROYAL POWER.}

the instinctive fear on the part of every man lest he should fall into the power of those who scarcely regarded him as a fellow-man, and whom he, on his part, could not understand, as they differed from him in thought and feeling and customs.

This was a powerful notive since it was based on a natural self-regard, and it was for the same reason a permanent one, and gave a direction to the nation's development. The soul of every Hungarian became keenly sensitive to the importance of national unity, since with this was linked the interest of each individual.

Hence, at a time when other nations paid little attention to affairs of State, in Hungary there was a strong public opinion on the side of the monarchy. The dangerous situation of the Hungarians became the source of their finest feature, their intense national feeling. To this they owed the maintenance of their unity at a time when other nations were becoming disintegrated. This sentiment made them successful in their struggles with powers greater than themselves, and enabled them, by preserving their autonomy for a thousand years, to build up a State of which they may well be proud. In the future, also, the condition of their existence will be the preservation of this national sentiment in all its depth and intensity, but united with humanitarian ideals, and provided that devotion to their race does not degenerate into that foolish chaurinism which is inconsistent with the calm self-respect that alone can make individuals or nations distinguished, and which is merely idle vanity, blinding men and nations alike, making them weak as well as ridiculous, hindering them from seeing their own shortcomings, awakening in them the desire for dangerous enterprises, and alienating sympathy, since its only aim is to offend.

One other circumstance probably had some influence in bringing home to the Hungarians the need for a central authority. In all probability the Hungarian 
conquerors were not very numerous, and the subjugated races, especially in the mountatinous districts where the Hungarians did not care to settle, preserved their nationality. Though not proved, it seems very likely that the Slavs of the northern counties of Hungary are the descendants of the original inhabitants. Is it not probable that this state of affairs had the same effect upon the Hungarians as a similar condition in England had upon the Normans? It is true that history tells us nothing of any revolt or disaffection on the part of those races, and the scanty records only show that there could not have been any organised warfare worthy of note. It would be a wonder, however, if the indigenous races accepted the Hungarian hegemony without a struggle. Psychological considerations support the supposition that they did not look kindly on the invading Hungarians, who conquered them by force of arms and robbed them of the inheritance of their fathers. 'They must have felt bitterly, and a legacy of discontent must have been handed down from father to son, a discontent which doubtless manifested itself in predatory raids, in murmurings and threats, all which must have had their influence upon the ideas of the Hungarians. The Hungarians, seeing that enemies threatened them from without, while within their borders also were hostile races, could not become absorbed in local interests, but were almost compelled to be true patriots, realising that they must hold together, and that the first condition of their unity and hegemony was the kingly power. If this indeed was the situation, and if those are wrong who say that in the time of St. Stephen only one language was spoken, then this situation must have had a powerful effect upon the desire for unity, since it revealed its influence in the more inaccessible mountainous districts, where local independence could most easily have been set up.

Where the Hungarians saw only their kindred and grew up in the consciousness of their strength, there 


\section{SOURCES OF THE ROYAL POWER.}

the geographical conditions which would have faroured separation were absent.

The districts in which they dwelt were easy of access by the Court, and so it was comparatively easy to maintain the authority of the crown.

The consolidation of the monarch's power was partly due to the fact that the monarchy was established at a favourable moment. The failure of their wars of aggression had convinced the Hungarians that the old system had become obsolete. Many realised that the severer discipline and better organisation, the religion and culture of the west, ought to be adopted. The Norman lings of England found it of great advantage that their organised army had became the leading class in the State. On the other hand, Charlemagne saw what a disadvantage it was that the Frankish conquerors had lived for nearly three centuries in their acquired territory without having organised it into a whole, so that every district of it formed a separate unit, and he met with considerable difficulty in abolishing this condition of affairs. St. Stephen, though his position was not so favourable as that of William the Conqueror, was confronted by an easier task than that which Charlemagne had to face. The nation he was called upon to govern was partly nomadic, and had not yet become firmly attached to the soit, while the people, dwelling within a comparatively small area, had considerable intercourse with each other, so that local potentates could not arise. There had not yet been developed among the conquering Hungarians that organised hierarchy which could provide the inhabitants of a certain district with a leader and an organisation. The tribal system was dying out, but its place was not yet taken by any new system. The sense of equality, inherited from the time of the migration, was still strong, and this proved a help to the ling against any would-be local rulers.

No one was willing to pay homage to an equal. If the people had to yield obedience they would do so only 
to their prince, atterwards their king. The Franks also had this same pride, but a strong monarchy had not yet been established that could profit by this sentiment, and when the monarchy was instituted, the great inefuality in wealth and the tyranny of the strong over the weak had altered the character of the nation, and life had taught men the lesson that the more fortunate neighbour might reasonably claim obedience if, in return, he furnished defence, which the monareh could not do.

In Hungary the sentiments and customs which arise out of sucial inequality had not become traditional. Differences in wealth and power which had continuously increased and the discord which sprang from these differences, inclined the bulli of the nation-the middle class-which regarded its liberties with a jealous eye, to support the king.

Moreover, the monareh initiated a religious and social revolution, which, had it failed, might have led to the downfall of the monarchy, but, as it proved successful, became a source of strength. The two fundamental principles of the new age-Christianity and the right of private property-were championed by the monarch, who thus succeeded in attaching to himself many powerful interests. Power becomes legitimate only when it lays the foundation of a nation's prosperity, and when the leading ideas of the age connect themselves with the conception of that power.

The eyes of the whole nation were turned towards the king, because all men felt that they needed a leader.

They also realised that, situated as they were among foreign races, with a powerful neighbour on the west and threatened with invasion on the east, their very existence would be in danger if they were without some strong central authority. Thus the monarchy became identified with the idea of national existence. It meant national glory and independence. At critical times, the bulk of the nation at least always sided with the king, since by the sceptre of the king it was protected from 


\section{SOURCES OF THE ROYAL POWER.}

foreign aggression. Further, the majority of the people sought the king's support against the nobles. Public opinion, therefore, was strongly in favour of the king and of national unity, and was opposed to a feudal nobility and system of fiefs. It was from the king that the people looked for protection of their common interests, and not from local magnates. In the eyes of the nation the only form of State life which could endure, was the undivided unity of the country represented by the monarch.

These circumstances explain the rise of the Xrpád dynasty, and made it possible for the kings to fulfil their rocation at a time when the kings in other countries had comparatively little real power.

All these motives operated, sometimes weaker, sometimes stronger, until the battle of Mohács, and gave to the monarchy that vitality which enabled it to revive again and again, and persist as the most distinctively national institution in spite of many adversities. The Hungarians became so strongly royalist as to be in this respect unique.

The circumstances which have been enumerated, however, merely made it possible that in Hungary the kingly power should be strong in spite of the many conditions which, during the Middle Ages, tended to diminish that power.

Great and sustained efforts, and the co-operation of many causes, were necessary in order that the monarch, taking advantage of farourable circumstances, should convert this possibility into an actuality, and should retain the leadership of the nation for five centuries amidst the gravest dangers, as was the case in Hungary.

The Xrpád line of kings was exceptionally talented, and eminently fitted to rule a warlike nation. They were brave, and strong-willed, and were able to control the spirits of the people. Even the weaker kings were not devoid of talent, while in every century some great ruler 


\section{DEVELOPMENT OF HINGARIAN LIBERTY.}

arose among them who more than atuned for the shortcomings of his less-gifted predecessors, and laid up a store of prestige for those who followed him. St. Stephen, St. Ladislas, and Kálmán were the pride of the eleventh century. It was fortunate for the monarchy that at the time of its inception such great personalities served its interests. The value of an institution has often been augmented by the emineno. of the men who have created it, and stand identified with it in the eyes of posterity. It was fortunatu, also, that the three great kings mentioned above were not the lind of men who merely awaken awe but not attachment, but, on the contrary, won men's hearts by the charm of their personality.

IVilliam the Cunqueror and IIenry 11. were great kings, but they have not beeome surrounded by such a halo as St. Stephen and St. Ladislas. Búla Ill. was the great Hungarian king of the twelfth rentury, and Bial 18 . of the thirteenth century. Even after the time of the Krpáds every century had one great king at least. The fourteenth century had Robert Charles and Louis the Great, while the fifteenth saw Matthias. Great men not merely influence the politics of their own ase. but give permanence to a new conception by means of institutions. This happened in the history of the monarchy. Great men seized the farourable moment for the creation of an institution that should endure. The permanence of an institution depends upon its ability to perform the task expected of it. As the rocation of a king was preeminently the defence of the nation's independence, his success was decided chiefly by his capacity in this direction. The king has always been the first soldier of the State, and the head of all its military forces.

Bound by oath to protect his realm, no part of his duty has he endeavoured to discharge more faithfully than this.

The fate of the monarchy in Hungary was decided by the eminent success of her first kings in organising 


\section{SOURCES OF THE ROYAL POIVER.}

the nation for purposes of defence under their own leadership.

Every free-born Hungarian was obliged to perform certain military duties, and to serve under the command of the king. The owners of the fortresses, which were to be found in every district, had each some special military task. The king had soldiers in his pay, and he also obliged several powerful nobles to maintain a certain number of troops in return for gifts, but the bulk of the army consisted of the ordinary citizens.

This system established direct communication between the king and the majority of his subjects. The military organisation of the nation became the organisation of civil society as well, and the centralisation attained for military purposes was the highest degree of centralisation of which society at that time was capable, and established as complete a harmony in the State as was to be expected.

It guaranteed power to the monarch, but at the same time limited that power and rendered its abuse difficult. It placed the king in such a position that if he knew how to manage the nation he could marshal the whole of its forces against a neighbouring State, while it made it impossible for him to turn those forces against the nation itself. It made ready the nation to serve the king, yet obliged the king to act in harmony with the wishes of the nation.

In the course of time, this organisation weakened and the king's position became more difficult. It became necessary to find a substitute for the garrisons of the fortresses.

In the time of the Angevins, the aristocracy was led, partly by patriotism and partly by ambition, to maintain troops, and the army of Louis the Great was largely composed of the private battalions of noblemen. In his case the arrangement worked very well, in consequence of the intellectual superiority of the great king, but it contained the germs of great dangers. As a reward for 
lhe "banderia," a great pant of the crewn estates became the property of the mobles, and the chief military power "as in the hands, not of the kingr, but of these not very reliable noblemen. Had this beeome the sole military organisation, the monarch mun have lost his supremacy orer the forees of his realm, and the foundation of his authority must have been shaken. But the monarchy "las sared by the pessibility of a different system.

Its interests demanded above all things a standing national army. Had such an army beeome the backbone of the national defence, the history of Hungary might have been different.

It was not in aceordance with the nation's traditions, lemever, to entrust its defence to paid soldiers. To do s) would have involved the cessation of the nobles' immunity from taxation, and public opinion was not ripe for this.

Cin until the reign of Math hias was a standing national army created, and before his time monarchs had to hind some other means of remaining masters of the military forces. They reinstituted compulsory military service on the part of the middle classes, and introduced the system of compelling landwuners to supply soldiers in proportion to the number of their serfs.

The legislature took care that the forces raised should be adequate to the country's needs, and that they should remain under the influence of the king. The banderia of most of the nobles were ranged with the banderia of the counties, and the command was entrusted to roval officials.

The laws could not, howerer, be entirely enforced, and the kings of the mixed dynasties did not derive as much power as the Krpád kings had from the military

* A "banderium" was a body of soldiers equipped and main. tained by one of the powerful notiles or magnates, who was entitled to lead it into battle under his own hanner. Every magnate had to equip such a banderium, the size of which was proportionate to his own wealth. There were also banderia which were equipped by the Counties and led by the Connty Lieutenants. 


\section{SOURCES OF THE ROYAL POIVER.}

organisation, but since even during the most critical times there were always some national forces apart from the armies of the nobles, the crown and the national unity were never without a defence. The monarchy, in its darkest day, never sank so low as it did in many European States. The nation was legally compelled to exert itself to supply the king with military forces, in a manner scarcely paralleled in other countries. It was the fear of the Turk which enabled the king to lay this compulsion upon the nation.

This fear took the place of the motive formerly supplied by the antipathy between Hungary and Western Europe, an antipathy which had not entirely ceased, but had become much weaker. The Turks were as much foreigners as the Germanic and Slavish races had been, and they awakened in the Hungarians the foeling that a strong king was neecessary.

Every man's sentiments and personal interests were opposed to the rule of the Sultan.

Another powerful instrument in the hands of the king was his wealth. He needed 10 be rich in order to maintain his power, and the rrpád kings had realised this. St. Stephen took possession of vast artas for the crown, and the income from these dominions was the monarch's chief revenue, to which were added certain tolls, duties, income from the mints, and some constant taxes. It was very important for the monarch that in this way he gained an income independent of the nation's will. As time went on, however, the financial position of the monarch grew steadily worse. The bulk of the nation approved of the policy of retaining these dominions for purposes of national defence, yet in spite of the fact that the later Arpád kingss endeavoured to regain the vast territories which their ancestors had given away, the king's estates were continually diminishing. It was also disadvantageous to the Treasury that more and more people were freed from taxation. Just at a time when the defence of the country presented greater difficulties than 


\section{DEVELOPMENT OF HUNGARIAN LIBERTY.}

ever, and when it was only by means of a paid army that the king could maintain his supremacy, and when, consequently, he needed money above all things, the sources of his income were drying up. If the monarch had been able to create new sources of revenue, and to organise a powerful paid army, he might have aimed at absolutism, as was done in many other liuropean countries. It had an important bearing on the nation's history that this was not possible in Hungary, and that at at time when the necessity for a paid army was becoming greater and greater, the fortune of the ling was so much diminished that he was driven to new and extrandinary tasation. From the time of the Hunvadie the monarchy had to depend upon war taxes roted by Parliament, yet even then the public spirit of the people enabled the king to discharge his proper functions.

Though his position was sometimes a very difficult one, he was always able to maintain the nation's unity.

Besides national defence, one of the tasks of the kings was to consolidate the new legal srstem which they had introduced. The foundation of this sistem was laid by the Yrpid kings, who made the crown the source of all legal rights. The county lieutenants, like the "grafs" of Charlemagne and the rice-comites or sheriffs of William the Conqueror, discharged both military and administrative duties, and in both directions acted on behalf of the king. They were nominated by the king who ruled through them.

The . Arpid kings, moreover, travelled a great deal about the country, in order to come into personal touch with the inhabitants of the various districts, and thus kept their finger upon the nation's pulse. The king was supreme arbiter in all matters, the main source of justice, the highest tribunal, the bestower of farour, and the support of the law.

But decentralisation struggled with uniform government eren in Hungary. Fired by foreign example, and supported by the distribution of power, now and then 


\section{SOURCES OF THE ROYAL POWER.}

some great nobleman endeavoured to wrest the government of some district from the hands of the king, but such efforts never achieved complete success. The legislature, the administration, and the judicial system remained on the whole uniform and subordinate to the king. The various offices did not cease to be State offices, and sovereign rights never came into the hands of private persons. Many centuries elapsed before the elective system commenced to obtain a footing, side by side with the method of numination, and even then it did not endanger the king's supremacy, or the national unity, but on the contrary it gave a part in the administration to such elements in the nation as were the king's allies in his struggle to maintain the nation's unity.

As already mentioned, one source of power to the Xrpád kings was the introduction of (hristianity and the royal patronage of the Church. From this source the monarchy continued to derive strength. The functions which are now performed by educational institutions and by the public press, were performed during the Middle Ages by the Church alone. The fame which a man might expect from his contemporaries and from posterity was settled by the priests. Popularity and respect were gaincd or lost through their action.

The Church rendered a vast service to the monarchy by the glory with which it surrounded the two sainted kings. The conception of a monarch was so highly exalted by the Church's blessing and championing, as no other agency in that period could have exalted it. Not seldom the common belief credited the king with wonderworking powers. It was generally believed that at the tombs of St. Stephen and St. Ladislas, the blind and the deaf could be cured.

Concord with the Church had further direct advantages for the king. When it is remembered how detrimental to the Empire was its quarrel with the Papacy, it becomes evident how fortunate it was for 


\section{DEVELOPMENT OF HUNGARIAN LIBERTY.}

Hungary that the . Rprad lings, and subsequent monarchs also, maintained, on the whole, triendly relations with the Vatican. Hungary never found it necessary to purchase peace at the price of the surrender of royal prerogatives, or of being compelled to side actirely with the Pope in his various eonllicts. Ifungary retained the right of deciding upon her foreign policy in accordance with her own interests, and in lilling vacant benefices kept a free hand for herself in a way that few States did. Some of the rights of the . Ipostolic kings were occasionally infringed, but they always maintained power enough to make the Chureh dependent upon them. This influence of the ling wer the Clourch was the more valuable because the Church possessed enormous wealth, and, therefore, ereat peower in Hungary.

The Chureh banderia, on which the king might place more reliance than upon these of the mobles, as well as the moral support wheh the high ecclesiastical dignitaries gave, and the temporary income from vacant benefices, proved very helpful to the ling at critical times.

The Mrpaids established the monarchy on firm foundations. Ifter their time, its power declined, but was never destroyed, and the king remained the symbol of the nation's unity and independence. The national ideal and instinctive self-regard were the king's constant allies. The caunes which led the people to recognise the power of the Mrpáds as a national necessity did not cease to operate in after vears, but continued to make it possible for the monarchy, while pursuing its high rocation, to acquire fresh strength, and to struggle victoriously against the decentralising tendencies of the age.

What the kings lost of their prerogative was gained by the whole nation, and not by individual nobles or districts.

From the almost absolute rule of the first. Irpaids, the nation's constitution was gradually developed. 


\section{CHAPTER IV.}

THE FIRST BEGINNINGS OF A CONSTITUTION IN HUNGARY AND IN ENGLAND DURING THE ELEVENTH AND TIELFTH CENTURIES.

During the Middle. Iges, through inevitable caluses, free institutions grew up side by side with the monarehical power. It may be interesting to trace the steady advance from age to age of the spirit of freedom, noticing the circumstances amidst which it was fostered, and it will be helpful to us, in our task, to compare the history of Hungary with that of England. In both countries it was the strength of the monarchy, securing internal order and peace, which rendered prosress possible, and it is due to this fundamental similarity that the two constitutions followed similar lines of development. This is why a comparison between the two countries is so instructive, for it enables us to ser which phenomena in the history of both were the effects of this common characteristic, and which traits were peculiar to Hungary.

The first period we shall examine lasted from the: eleventh to the commencement of the thirteenth century. Alike in Hungary and in England that period was chatacterised by the unchallenged supremacy of the monarch, yet, at the same time, we cannot fail to discern the germs from which constitutional government has been evolved in both countries. To so great a height had William the Conqueror and St. Stephen raised kingship, that during the eleventh and twelfth centuries the dominant power in the State was that of the king, but 
even then there were a few circumstances which limited that power, and formed a check upon autocracy. The monarch had no separate army, neither had he the support of a bureaucracy, and, moreover, the nation was quite able, and on occasion willing, to put a formidable fore into the field. Tho grovern the people successfully, therefore, demanded an able and commanding personality. The strcessor of a powerful monarch might suddenly find limelf impotent if he ceased to be lilied or feared. The reign of Stephen, in England, presents a striking contrast to that of his predecessor, Henry I., and his stucessor, Henry 11. Stephen was as weak as the others were powerful. In Hungary, leter, who succeeded the omnipotent Si. Stephen, was deprived of his throne by a revolution. Jo king who was unable to lead an army, and to maintain his authority by force, could count upon obedience. Peter, Samuel, and Salamon were driven from their thrones by their factious and revolted subjects, because their absolutism injured many powerful interests, and their policy was opposed to the current of national thought and sentiment. In England, the rebellious barons conquered Stephen and imprisoned him. Many kings in circumstances such as these, have sought relief in the concession of privileges to the people. Magna Charta was granted by John becatse the armies of the barons, backed by public opinion, were stronger than the king's mercenaries.

If a king chanced to be a minor, the difficulty of his position was aggravated. The Hungarian nobles held undisputed sway during the minority of Stephen II. It is no wonder that in after years, this ling met with a grave case of disobedience. On the death of Géza II., while his sons were still minors, it was again the nobles, and especially the high ecclesiastical dignitaries, who grasped the power. Archbishop Lucas was practically supreme, and it was he who preserved the throne for young Stephen III. As a consequence, he was bold enough to oppose the will of the king, and even to ex- 


\section{THE FIRST BEGINNINGS OF A CONSTITUTION.}

communicate him for wasting the treasures of the Church in warfare.

The king was terrified, and humbled himself before the archbishop, who thereupon remored the ban. The fruit of his influence over the young king was the first charter dealing with ecclesiastical matters.

Henry 11I. was the first king after the Conquest, who succeeded to the English throne during his minority, and it was during his reign that the provisions of Magna Charta became effective. Archbishop Langton was allpowerful in the State, and during the ling's minority the government was practically conducted by him and by the great barons. Even when the king attained his majority the barons were not ready to relinquish the power they had tasted during his earlier yars. A minority, placing the supreme power as it did, for a longer or shorter time, in the hands of the nobility, always furnished an occasion for fresh demands of concessions.

The power thus gained, and the frequent humiliations of the monarch, had a great effect upon the relations between ling and people.

The king's position was considerably weakened by the circumstance that the laws relating to the succession were as imperfect as all other branches of the civil law. During subsequent centuries the principles governing the succession became definitely settled. The rule indicated by the words: "Le roi est mort, vive le roi!" strengthened and assured the position of the monarch, and by its invariableness awakened respect for the royal line. But during the period we are now considering only the rights of the reigning family were recognised, and it was by no means a settled matter which nember of that family should occupy the throne. This uncertainty bred much animosity and contention amongst the members of the royal family, and this in turn increased the selfesteem and power of the nobles. Many a prince owed his crown to the favour of the people. Aba Samuel, in Hungary, had no other right to the throne but such as 
the will of the nation gave him. St. Ladislas was practically forced by the nation to oceupy the throne, although King Salamon was still alive. P'opular risings gave Béla 1. and Géa 1. their crowns. laets such as these were deeply impressed mpon the nation's memory, and revived the ideas of ancient freedom and the people's sovereignty. Those who had created a king were not ready to surrender all their atuthority to their creature.

Even their descendants could not forget that the ancestors of the reigning monarch had once sought the goodwill of their forefathers. The custom followed by the Xrpaid dyasty of handing over the government of certain parts of the country to younger members of the reigning family, had a similar effect. The disputes between these local rulers and the king gave rise to civil wars, or rather, perhaps, partisan conflicts, and the need of supporters in these struggles increased the value of the nobles in the eyes of the contending rulers, while those who were able to fight and to bring with them a large following, were led to estimate more highly their own importance. In England, no sooner had the Con(pueror died than his sons contended for the crown. Wrilliam 11., with the aid of the barons, excluded his elder brother from the throne, and Henry 1. also gained his crown by violence. Certain formalities were, nevertheless, observed. There was some kind of election, and the king, at his coronation, took upon himself certain obligations.

Even the mightiest kings felt themselves compelled to win the support of the nobles to the succession of their son and heir, lest their throne should become the prey of some of their ambitious relatives.

St. Stephen spent the last years of his life in trying to gain the favour of the aristocracy for his heir, Peter.

Kálmán the Mise used both violence and indulgence as his instruments for assuring the throne to his son. This one consideration alone was enough to compel the autocrat to pay some heed to the wishes of the people. 


\section{THE FIRST BEGINNINGS OF A CONSTITUTION.}

In England it led even the strongest hings to court the goodwill of the barons and to make concessions. The stern Conqueror became mild and friendly when the succession came into question, and the powerful Henry II. became reconciled even with his great enemy, Thomas à Becket, in order that his son's succession might be assured.

The king's power was also limited, as we have seen, by the necessity he was under of associating with himself in the government of the country the leading elements of society. Many institutions to which former centuries had given birth, and which had been the organs of free government, still survived. In England both the Norman and the Plantagenet kings gathered the leading men around themselves. The Anglo-Saxon customs had not died out, and the Anglo-Saxon ideal of freedom lived on during the time of the Norman kings. It is true that such institutions underwent considerable change, yet the fact that they were an organic outgrowth from the past added greatly to their strength. The constitution of the great council of the Norman kings is not accurately known. Very probably it was composed of the crown's vassals alone. It had no well-defined sphere of activity. The place of a legal constitution was held by customs, and these fluctuated with the changing political situation. The duties of the council were to discuss any great military enterprise; to determine what taxes should be levied; to act in a judicial capacity, and generally to advise the king what his own interests or the power of the nobles demanded. The councils were sometimes larger, sometimes smaller, but those always attended whose power rendered their aid valuable and their demands weighty. William I. and Henry II. summoned a council to increase their own strength. Stephen and John Lackland were driven to the same course by sheer necessity. It was of the highest importance in its influence on the development of the constitution that councils met thus from time to time, and played a decisive 
part in weighty affairs of State. Posterity was spurred on by the example, and the claims of later ages found in these councils their precedent and their legal basis.

In Hungary, esents took a similar path. The Yrpád dynasty also maintained the institution of national councils. These did not entirely resemble the English councils, for they rested on broader foundations, and preserved more nearly their uriginal form. They did not consist exclusively of the fendatories of the crown, but comprised all the free members of the nation. All who were strong enough to claim a share in the management of public affairs attended. The first attempt at a system of representation was made by Bela I. This king, strong in the affection and esteem of the people, sent to every town a summons to choose two men to represent it upon the council. The pagan element of the population, however, offered such a stubborn opposition to the scheme that the attempt failed, and the personal attendance of all free men who chose to be present remained the rule. How many actually availed themselves of their risht, it is impossible to say. Several formula have come down to us which show that the councils had not all the same composition. St. Stephen, in a letter to his son, draws a distinction between the younger men, whose most appropriate employment was the pursuit of arms, but who, nevertheless, might gain admission to the council, and the "more ralued and experienced, the eminent and venerable elders of the nation," without whose adrice a king should determine no important matter, and who were pre-eminently members of the council. One of the laws of St. Ladislas runs as follows:- "We, the heads of the Hungarian Kingdom, in full council assembled," and another begins: "Under the presidency of King Ladislas, we, all the Bishops and Abbots, together with the king's rassals, on behalf of the whole of the clergy and people, in council assembled."

When King Kálmán the Wise saw the decline of 


\section{THE FIRST BEGINNINGS OF A CONSTITUTION.}

the council, and the diminishing respect for the Court which accompanied that decay, he assembled the chief men in the kingdom, and with the aid of the country's whole senate, examined and revised the laws of St. Stephen. Otto von Freisingen, speaking of the Hungarians in the reign of Géza II., said that "all the nobles go to the king's court, each taking his chair with him, and there continually discuss public affairs, and during the inclement months of winter, they do so in their own homesteads."

The charter in which Stephen III. granted certain privileges to the Church ends with the words: "And all the above privileges are to be regarded as decisions of the Council, consisting of his Majesty's exalted mother, the queen, the archbishops, bishops, bishops-elect, priors, abbots, heads of counties, rassals, and others." And in a document of the time of King Emmeric, we read of the "Common Council of the whole nobility and gentry of the country."

From these formula we must conclude that there were two kinds of councils-a smaller one, consisting of noblemen and church dignitaries, which was the chief organ of the king's government, and was the one called by King Stephen the Council of the Elders, and a great national council, in which all free men, including those whom King Stephen styled "the Younger," were entitled to take part. Sometimes the king held a conference with the population of certain districts. The intervals at which such meetings were convened probably depended more upon the necessities of the political situation than upon any established law. It was naturally no easy matter for a large number of people living far apart to come together and to find accommodation in the same town, and for this reason it happened that the smaller council, which was probably the standing council of nobles, met more frequently than the general council. The latter was only convened in exceptional cases, if, for example, the king desired to win the good- 


\section{DEVELOPMENT OF HUNGARIAN LIBERTY.}

will of the multitudes, or if he were threatened by a rival against whom he wished to gain the help of the majority; if he desired to make such laws or innovations as he thought would awaken interest and sympathy in different strata of the people; if he intended to lead the assembly straight against an enemy, or if some general discontent or rebellious spirit compelled the king to hear the people.

The functions of the different councils were not clearly defined. This alone made it possible for one to take the place of the other. Probably neither had any rights which were granted by the law to it exclusively. Strictly speaking, all political power belonged to the king. The people only had so much influence as the situation gave them, or the king was inclined to concecle.

The prudent St. Stephen gathered round him the most eminent men, not because he did not feel entitled in his own right to make laws which should be binding upon the whole nation, but merely because, as he said, "the discussion was useful." "If thou meetest with the wise, thou shalt be wise." This was the principle of that eminent monarch, who became the second founder of Hungary. He saw that it was not prudent to decide alone in all things, for it must lower the king in the eyes of his subjects if criticism and dissatisfaction should always be turned against his person. To his son he gave the adrice: "Judge not in person, lest when meddling with low concerns, thy royal dignity should diminish." And also: "Beware of being a judge." $\mathrm{He}$ appears to have wished the heads of the nation to have a share in the responsibility of legislation, and it was always in the council, therefore, that he exercised his functions as a legislator. In the code of St. Ladislas, the hand of the king is nowhere to be detected. It would appear that all the laws were framed and introduced by the nobles. In another code, the king is mentioned, but only as president. Stephen III. ascribes the introduc- 


\section{THE FIRST BEGINNINGS OF A CONSTITUTION.}

tion and enactment of a law to certain nobles whom he mentions.

It appears, therefore, that the final decision in important matters rested sometimes with the council and sometimes with the king. 'The members of the council discussed every question, and had a hand in all the affairs of State, yet their co-operation was not indispensable. They made laws affecting Church and State, and administered them, but there was nothing in the constitution to prevent the king from acting on his own sole authority. King Kálmán once replied to the Doge of Venice that "the proposed peace would not be binding enough if contracted without the consent of the council." It was not that the king had no right to decide alone, but that he perceived his resolutions to need the Council's approbation in order to be effective. This view of the situation is characteristic of the times as well as of the "isdom of Kálmán. Though the king was under no compulsion to summon a council, yet the political exigencies and the actual distribution of power frequently rendered such a step necessary. And in Hungary, as in England, it was of the first importance to posterity that these councils survived, even during the period of great monarchical power, and played a decisive part in the most important affairs, in legislation, in problems of succession, and in political and financial administration.

Their survival rendered it unnecessary to create them anew in later times, as had to be done in France. They originated when the nation first occupied its European home, and they accompanied it along its path of progress. A halo of antiquity surrounded them, for their institution was older than that of the crown itself, and the nation firmly believed that the kingship owed its origin to the free will of these councils.

The English as well as the Xrpid kings, though driven to obtain the aid of the leading men in the government of the country, endeavoured to keep the 


\section{DEVELOPMENT OF HUNGARIAN LIBERTY.}

management of public affairs in the hands of their own nominees. But, in spite of their efforts, they were obliged to accept the principle of hereditary succession and to make some part of the State's machinery independent of central control.

The king needed the support of the nobles, and as the gifts of estates was not a sufficient inducement, he had to surrender some part of his political power itself. In England, the greater dignities, with the powers and duties attaching to them, tended to become hereditary. The king tried to counteract the effect of this by creating new offices and investing their holders with some of the functions formerly exercised by hereditary and territorial nobles. Yet, contrary to his interests, the greater earls, especially the earls palatine, wielded almost sovereign powers; in some cases, even the office of sheriff descended from father to son, and the baronial courts exercised important jurisdiction. The administration thus fell into many hands. Very often, too, the great landowners were little less than kings within their own domains, though their autonomy had no legal foundation.

In Hungary, similar tendencies were to be observed. It is true that the kingdom of St. Stephen was not based on feudalism, like that of William the Conqueror, and it was, therefore, easier for the king to oppose the tendency of dignities to become hereditary. Moreover, no foreign country influenced Hungary by its example, whereas the feudal system of Normandy had a wellmarked effect upon England. Yet it proved as impossible in Hungary as in England to prevent the offices attached to the ownership of great properties from becoming hereditary. The causes making for decentralisation bore their fruit in Hungary too.

In the Golden Bull the king declared that the office of lord-lieutenant of a county could not be inherited, nor could other offices. But the monarch was often obliged to part with his prerogatives in order to gain the help or goodwill of some powerful family, and some of these 
acquired a certain sovereignty over their serfs and retainers.

But this was not the chief difficulty with which the king had to contend. Encroachment upon the monarch's sovereign rights was the exception in Hungary as in England. Had the king been able to obtain the same absolute control over the executive as was subsequently gained by Louis XIV. of France, or Frederick II. of Prussia, his power would have been enormous. But this he could not accomplish.

The Norman kings of England had, as a rule, the right of appointing the vice-comites or sheriffs who represented locally the royal power. The Arpád kings in Hungary exercised the same right over the lieutenants of counties and the lower officials.

Nevertheless, the whole administration was penetrated by a certain spirit of independence, because those who held any office carried into it their personal fortune and authority. Moreover, distance made effective control difficult and the central management of affairs impossible.

The principle of election, also, was introduced. In England, the coroners were elected in the county courts, while in Hungary the principle came to be applied in the case of the less important offices, in the towns, and to the committees entrusted by the law with the performance of certain special tasks. But it was not the mere fact of election which bred independence in the administration. That was due partly to the character of the men who filled the various posts, and partly also to the general state of affairs. The king only assented to the principle of election when the danger lest all offices should be seized by the nobles became imminent. In England the powers of the sheriff were curtailed, and his place was taken by justices appointed by the king from among the country gentry. In Hungary, the lord-lieutenantship of the counties was threatened with a similar danger, for the office was rapidly becoming the exclusive preserve 
of the more powerful nobles. It was favourable to the crown, therefore, that its supporters among the lesser gentry should be given a share in the administration. This reform kept the post to some extent under the control of the king, but it need hardly be said that it in no way affected the independent spirit of those who filled it. It was characteristic of the king's difficult position that he was constantly obliged to seek the help of the newly elected officials against the long-established dignitaries.

Before the growth of the monarchical power in the two countries, both the Hungarian and the English peoples enjoyed a great measure of freedom. They lived in an atmosphere which developed their self-reliance and ripened in their minds the knowledge that the shaping of their future rested with themselves. The limited power of the monarch could not transform this national type. The pride of the upper classes was fostered by their consciousness of power and by the king's need of their assistance. And kings were usually very careful in their behaviour towards them, especially the more powerful monarchs, for these were nearly always clever men, who knew their own interests. St. Stephen, in a letter to his son, urged him very emphatically to treat the nobles well. "If thou art peaceable, thou shalt be called king. If thou behavest haughtily towards the leaders and nobles, verily the strength of thy warriors will be turned to the destruction of thy realm, and they will betray thy country to foreign nations. Eminent men shall be to thee as fathers and brothers, for it is they who defend thy land, protect the weak, conquer thine enemies and extend thy borders." Where a king, who might have been formidable, held such sentiments as these because his wisdom approved them, and where only a short-sighted monarch could so entirely misunderstand the situation as to despise men whose help he needed, and whose power he could not destroy, the nobles of the country could not become ser- 
vile. Several historical incidents show that in Hungary, as in England, the king could not prevent the boldest freedom of speech. Bishop St. Gerard scolded King Aba harshly, and ordered him out of the church, and was never punished. We have already seen how Bishop Lucas treated Stephen III. Among state dignitaries we meet with many such defiant characters. Even the ironhanded and powerful Kálmán had to give way on one occasion. When he made war upon his brother, his knights assembled and said: "We do not see the reason for this strife. If they wish to appeal to the sword let them meet face to face and the victor shall be our lord." They refused to shed the blood of their compatriots, and the king was obliged to yield. In the reign of Stephen 11. a still more defiant spirit manifested itself. The king was on foreign territory when his whole army refused to obey him. Its leaders declared themselves against the war, as it was injurious to the country, and they resolved to start for home. "If the king wishes to fight, let him do so; they will elect another king at home." The tyrannically disposed Stephen gave way, and took what revenge he could later.

Such was the monarchy, and such the people whose defiant spirit restricted the king's power more than written law. The blunt candour of the period is expressed even in its laws. In the Golden Bull, for instance, the introduction states that the nation's liberty had been threatened by the tyranny of such kings as were led "either by their own revengeful spirit," or by "evil-minded counsellors." In England, Thomas à Becket openly defied Henry II. Simon de Montfort, when the king called him a traitor, replied that "were he not king he should pay dearly for the insult." On the occasion of the French War of Edward 1., the Earl of Norfolk refused to follow the king to Flanders. Edward declared that the earl should either go or hang, but the earl replied that he would neither go nor hang. This repartee is character- 


\section{DEVELOPMENT OF HUNGARIAN LIBERTY.}

istic of the barons' haughty and defiant spirit, which the king was powerless to crush.

Even among the humbler classes, the temper was the very reverse of servile. The self-respect of the Hungarian king's soldiers had always been considerable. Between them and the highest nobility there was never such a gulf as separated the different classes in England after the Conquest. They all remembered with pride that they were the descendants of the early conquerors of the country. The simplest Hungarian squire thought himself superior to nobles of alien blood. The codes of laws show how much less inequality there was in Hungary than in any other country at that time. In other lands, not exen excepting England, the punishments for the different offences varied with the rank of the injured party. This inequality before the law did not merely affect the distribution of pririleges, but set a different value upon human life under the different circumstances enumerated in the codes. St. Stephen, however, had other standards. The amount of punishment was not to depend upon the social status of the person wronged, but upon that of the wrong-doer. It was not a matter of indifference whether the criminal belonged to the aristocracy or to one of the humbler classes. The state was injured most by a crime on the part of those whose duty it was to set an example.

The unlawful act of a powerful nobleman, who possessed castles and troops, endangered many more persons and interests than that of others, and therefore he deserved the severer punishment.

The legislation which embodied these principles was a splendid proof of St. Stephen's wisdom and of the nation's precocity. The king's idea could never have been carried into practice had any great degree of inequality existed. This product of the king's genius and the nation's political sagarity served to nourish the temper which rendered it possible, and although, in subsequent crnturies, differences depending on rank came 


\section{THE FIRST BEGINNINGS OF A CONSTITUTION.}

to be made in the blood-wite, yet traces of the original principle might constantly be detected.

During the eleventh and twelfth centuries the higher aristocracy in Hungary was only in course of formation, and as it was so severely controlled it never succeeded in winning for itself that absolute obedience and fealty which in France raised the great feudal lords to a position of power eclipsing that of the ling himself. The freedom-loving instincts of the rest of the nation, which had never borne the yoke of tyranny, became a powerful factor in securing constitutional liberty. King Aba counted on these classes to help him to withstand foreign influences and the nobles. Later on, the bulk of the gentry in their endeavour to maintain the ancient principle of equality in the teeth of the great feudal lords, became the natural allies of the crown. 'Their class developed under the king's protection, and this alliance increased their self-respect, until at length, as an acknowledgment of their support, they were conceded privileges from which sprang some of the most valuable elements in the constitution.

Class differences were more marked in England. They had their origin in Normandy, and were transplanted into the new country. They were accentuated by the circumstance that class distinctions coincided with distinctions of race. But the king's struggles with the nobility involved the speedy emancipation of the lower classes. The Saxon race was often flattered in order to secure its support against Norman disobedience. If a king was in difficulties he suddenly remembered the ancient glories of the Saxons, armed them and led them to battle against the revolting barons.

William II. and Henry I. acted thus, and the possibility of their doing so was one of the chief props of their power. This state of affairs increased both the selfesteem and the political ambition of the lower ranks of society. They could not fail to be deeply impressed by King Henry's appeal to them for assistance, nor could 


\section{DEVELOPMENT OF HUNGARIAN LIBERTY.}

they easily forget such words as "the king fears not the barons nor any of the Normans, so long as the Saxons are for him." Henry gave them a charter, and although he broke his promises, yet the promises themselves indicated the growth of the popular hopes and claims.

We may say then, that the two centuries we are now considering, owing to the political conditions which obtained, witnessed a considerable development of the spirit of freedom among the upper and middle classes of both England and Hungary.

There was also a rapid increase in the number of men skilled in the conduct of public affairs. In proportion as the desire for freedom grew, the nation learned how to use its freedom to advantage. As we have seen, large numbers of the country's leading men had some part in public administration and legislation, under the guidance of the king. This fact was of immense importance. It awakened in the nation the capacity for government and trained them to appreciate the real sources of power. It made them practical in their way of thought, and taught then political self-control, adding to the passion for freedom that measure of discipline, without which there can be no healthy organism nor sane political life.

We have now considered the public institutions and the general temper which developed side by side with the royal supremacy, up to the commencement of the thirteenth century. If we study the legal enactments we are struck by the extent of the royal power, but when we contemplate the real political conditions, we see that the power really remained in the hands of the nation, for without its aid the king was helpless: he was obliged to govern according to the will of the nation, provided that the nation had a will and was persistent enough. The leading classes in the country displayed therefore a great deal of independence, and they gained considerable experience in statecraft. In the centre, as well as in the provinces, the various institutions offered 
a sphere of activity to the more capable men, and while the institutions trained the men, at the same time the men developed the institutions.

But neither the functions of the different institutions, nor the rights of the various classes nor of individuals, were defined by law. Sometimes the people broke down all barriers and humiliated the royal power itself, while at other times they became the victims of the king's autocracy.

Such a state of things could not be final. Society, as it progressed, sought instinctively to determine by law the relations between its constituent parts. The power of the monarch was kept within bounds by living forces. Traditions of the past-the days of the Hungarian and Anglo-Saxon chieftains--kept alive the idea of liberty.

Amongst a people whose minds were fed by such memories, there naturally sprang up such customary rights as the advancing nation, with its increasing culture, desired to see converted into legal rights, as a bulwark against kingly despotism. Men wished the kingship, limited in its power in fact, to be transformed into a legally restricted constitutional monarchy. Custom had to harden into law.

This work was begun by the thirteenth century. The spirit of liberty, inherited from the past and not crushed, but only disciplined, by kings, revitalised, and made fruitful those institutions which had survived as remnants of the old autonomy, and were a defence against absolutism. The different constituents of the nation, aware of the actual distribution of power, endeavoured to bring about a corresponding distribution of rights. They were certain to succeed, because the people when united were stronger than the king, they were able to make a good use of their victory, that is, they really had the ability to govern themselves, and their claims were natural and moral.

Those who had long shared in the responsibilities of government were entitled to the possession of rights. 
Their claims were based on the common foundation of all rights, whether of prince or people, their ability, namely, to contribute to the common good. Their victory, however, was but one step towards the goal of a just constitution. Great ends are never achieved at a single stroke. Nature shows no favour to hasty projects, and grants the laurel wreath only to persevering effort which keeps the end ever in view. The achievements of the thirteenth century were but a foundation, upon which later generations had to rear the superstructure, but they were epochmaking, nevertheless. The long-cherished ideals of liberty and self-respect became partly realised in fundamental laws, and pointed out the direction of future progress. In the thirteenth century England and Hungary trod a new path, from which they never afterwards deviated. 
THE CHARTERS.

\section{CHAPTER V.}

\section{THE THIRTEENTH CENTURY. STEPS TOWARDS FREEDOM IN ENGLAND AND HLNGARY. THE CHARTERS.}

During a period of 150 years the Norman and Saxon races became recunciled to one another thruugh the uniting influence of common work and service. As this reconciliation progressed the nation felt less and less need of the monarchy, and bore its rule with less goodwill. The different classes of the community were working together under the leadership of the king, and a kind of alliance sprang up between them. Common oppression awoke the spirit of common resistance. The aristocracy was eager to secure the support of the lower classes, while these, on the other hand, gladly accepted the nobles as their leaders. The demands of the various orders of the community became harmonised, and led to the formation of a national programme. The fruit of this alliance was Magna Charta. Efforts had been made before, but none had achieved such a great result. King John was the enemy of all classes, and in his isolation he was obliged to yield to the demands of the nobles. In granting the Charter, the king did not aim at creating a new constitution, nor did he dream of transforming the existing State in accordance with theory. He took but little interest in the government of the country. His chief care was to assert the rights of the individual and of society, according to old traditions, and to maintain the feudal system.

The Charter defined the prerogatives of the Church. Care was taken that the king should not be able to use 


\section{DEVELOPMENT OI: HUNGARIAN LIBER'TY.}

his power as a feudal lord in robbing his vassals. This protection was extended to the subordinate vassals, and it was of great benefit to the merchants and the towns.

Most important was the clause dealing with the constitution of the National Council, enacting that the chief vassals of the Crown were to be summoned personally to the Council by royal invitation, and the smaller vassals collectively. It was very important, too, that the voting of taxes was placed in the hands of this council.

The Council had existed before, and it had probably been convened in accordance with the rules laid down in Magna Charta. It had been consu'ted when war taxes were to be imposed, but its constitution had not been settled by any law, nor had it possessed the legal right of controlling taxation. The Charter provided this legal sanction. In other matters, too, it operated in a similar way.

It gave legal standing to customs which experience had proved good, and which were in harmony with public opinion.

Its aim was to protect suciety and its customs from the arbitrary will of kings, and it added immensely to personal security by establishing the principle that no one should be imprisoned without trial.

These features gave the Charter historical importance and made it a turning point in the history of European liberty, for it embodied the two fundamental principles on which personal and national freedom is based.

In Hungary the renascence of freedom was brought about by the same causes as in England. Though the histories of the two countries display many differences, yet there is a great deal of similarity between them.

The need of a monarch was more keenly felt in Hungary than it was in England after the fusion of the two races, even if not quite so powerfully as it was before that fusion. The efforts of the German emperors, and of the Byzantine Emperor Nanuel, to subjugate Hungary, made 


\section{THE CHARTERS.}

the nation realise the great value of a strong and warlike king. In England, on the contrary, the king had no longer any special vocation.

The great kings, St. Stephen and St. Ladislas, won such popularity for the Crown as the harder personalities of the Norman kings were unable to acquire for it. Consequently the struggle for rights commenced later in Hungary than in England, and it took a different form. In England, three despotic rulers, the powerful but cruel Henry II., the vehement and adventure-loving Richard I., rightly called Cour-de-Lion, and the wilful, capricious and grasping John, made the movement one directly against the monarchy.

King John's opposition 10 reform forced the reform party to place the power in the hands of the leading: nobles. The ain throughout was to prevent unlawful acts by the king. Every article in the Charter seeks to assure to the various classes their rights.

In Hungary, the situation was different. The Colden Bull had been preceded by impotent government rather than by despotism. The belief in the necessity of the monarch had grown less strong. The nation had adapted itself to its surroundings.

Christianity and western civilisation had become deeply rooted, and the distribution of power among the European states was more farourable, so that the considerations which made the monarchy seem desirable had grown weaker. Under these circumstances King Emmeric, when engaged in strife with his brother, was unable to maintain the prestige of the Crown.

His successor, Andrew, was of a luxurious, extravagant, and vacillating character, and was quite unable to preserve order in the State. His debts, and the unruliness of his principal ministers, together with their utter inability to execute the law, were the chief reasons for the unhealthy state into which the nation had fallen.

The king himself broke the law, yet the greatest evils were the usurpations of the powerful nobles, and their 
grasping and insubordinate behaviour. A tyrant who can prevent the unlawful deeds of others, is a less evil than a king, who, while not himself respecting the rights of others, is at the same time unable to force others to respect the law.

Inequality in wealth and power between the members of the nobility became so great that the poorer among them saw their very freedom endangered.

Since the time of Béla III., the monarchy had become so weak that it was quite inable to prevent the disintegration of society. Linder these circumstances a twofold reform became necessary. The nation had to guard itself against the king's tyranny, but on the other hand, it had to maintain and even to increase his power. Even the faults of the monarch did not make the Hungarians forget that they needed the monarchy, and that if this defence were broken down, their country would become the prey of their powerful neighbours. 'Though the danger from abroad was not so great as in earlier times, yet the past had left its impression upon the nation's mind, and the racial differences between the Hungarians and their neighbours kept alive a sense of the importance of national unity.

The Golden Bull was an expression of these different needs. It contrasts with Nagna Charta in that it was designed to strengthen the king's power as well as to assure to the privileged classes their rights. It determined the rights of the nation in accordance with tradition in respect to military service, taxation, inheritance, and the administration of justice. All the nobles had equal rights.

While in England only the great feudal lords were personally summoned to the Council, and while the Charter only granted to vassals holding directly of the Crown the right to attend the Council, in Hungary there were no such differences, and every noble was entitled to attend the King's Council, which had to be convened every year.

Everyone present had the right to speak concerning 


\section{THE CHARTERS.}

any injury he had suffered, and although the chief purpose of the Council was the administration of justice, yet it furnished opportunities for the discussion of political questions as well. The nobles were all alike subject to the jurisdiction of the king and the palatine, and there was no trace of the feudal lawcourts. In short, no member of the class of nobles had more rights than another. All had equal right to own land, and to have a share in political power, and were liable to the same military service. The enormous actual inequality conflicted with this theoretical equality, and had brought about an alliance between the king and the bulk of the nobility, and one of the chief purposes of the reform was to give reality to this ideal of equality, and to oppose the exaggerated ambitions of the oligarchs who took as their example the nobles of other countries.

The Golden Bull established first of all the rights of the Hungarian nobility, but its protection was extended to their retainers, and also to foreign settlers. In this respect the Golden Bull was not less liberal than Magna Charta.

It did not by its form humiliate the king. The Bull was so drawn as to appear to be a favour freely granted by the king. It was not a contract between king and nobles like Magna Charta, but a decree by the sovereign.

Its contents clearly show that it served to strengthen the position of the monarch. It sought to defend the monarchy from the greatest danger which then threatened it, the lawlessness of the great nobles, and to ensure that the momentary folly or weakness of the king should not endanger the institution itself. It accomplished this by decreeing that the title and estates of the county-lieutenants should not be hereditary, thus attacking feudalism at its very roots.

In France and Germany it was because similar dignities were hereditary that the possessors of them hecame powerful and independent princes. The Golden Bull allowed county lieutenants to retain only their lawful 
salary, the rest of the income had to be handed over to the king. The king's jurisdiction extended over all, while the English Charter recognised feudal jurisdiction, too. Any incapable county lieutenant might be remored, and it was unlawful for several offices to be held by one man.

At the time of Andrew ]l., the power of the king was weakened by the circumstance that preceding monarchs had thoughtlessly given away large portions of their estates.

Prince Béla, however, before the Golden Bull was issued, endearoured to regain possession of this squandered property. His methods were violent and offended many powerful interests, but as they served the desired end of augmenting the power of the throne, the Golden Bull had no word against them. The king acted in the spirit of the Golden Bull when he examined the various grants, and cancelled such as appeared to him not to have been deserved, and it is characteristic that the power to do this was given to him by the victorious nobles.

One of the most difficult problems of statecraft is to harmonise liberty with order. How many great nations are still struggling with this problem, and how many nations in the past have come to grief because of their inability to solve it.

It is to the lasting credit of the Hungarians that as early as the thirteenth century they were careful of this twofold interest, and that even in the moment of victory the nobles did not forget the interests of the State, but endeavoured to strengthen the monarchy. In acting thus they displayed so much wisdom and patriotism as to rise above the creators of Magna Charta, that Charter so much admired by the whole of Europe. Only in one point does the Hungarian fall short of the English Charter, but that one shortcoming had many grave consequences. Magna Charta is superior to the Golden Bull in that it forbade the demanding of the usual military aids without the consent 
of the national council. The Golden Bull did not confer such a right upon the Hungarian Council, and it gave the nobility immunity from taxation. In England, the relations between the State and the various classes of the community were established upon a just foundation, and custom was replaced by definite laws, which proved the country's chief defence against the king in later times, when the monarchical power had a regular paid army at its command.

In Hungary, some centuries later, Count Stephen Széchenyi and Louis Kossuth had to repair the defect in the constitution, after the country had endured untold sufferings, from which England had been saved by her Charter.

Probably England's action in the thirteenth century was determined not so much by the spirit of equality and justice as by practical necessity. The Hungarian monarchs also were strong enough to compel their subjects to perform their duties. As we have seen, the Hungarian nobles were in other respects also less privileged than the English. How was it then that in Hungary the nobles were able to shift from their shoulders burdens which in England the most powerful feudal lords had to bear? The main reason was that in Hungary the State was less dependent upon the taxes than in England. It was Kálmán, one of the greatest Hungarian kings, who abolished the tax of eight denarii, which until his time had been paid by every freeman. Had his situation been the same as that of Henry I. and Henry II. of England, who reorganised the system of taxation, and extended it to everybody, very probably he would not have shrunk from acting similarly. The Hungarian kings were able to dispense with some portion of the taxes, and their military forces were better organised than in England.

In both Hungary and England, every man was theoretically obliged to fight in defence of his country. The Arpád kings, however, had frequently to repel attacks, 
so that in Hungary compulsory military service remained a living institution, while in lingland it became almost obsolete, as its enforcement was so rarely necessary.

As regards offensive operations, the Hungarian kings had a still greater advantage. The Arpáds rarely engaged in wars of conquest, but in their retainers they had a standing army, which could be employed even abroad.

The English kings frequently waged war in France, yet they had no standing army at their disposal.

The aggressive wars of the Xrpáds were generally brief incursions, while the Norman monarchs made conquests oversea, which demanded regular troops. The English kings, therefore, had to compel some of the more powerful nobles to supply the necessary men, and to follow their monarch to the wars, and in return for this assistance the nobles receired grants of land.

Under these circumstances the feudal lords became so powerful that the king could not safely rely upon them.

If he had no money to maintain a paid army, or to hire the troops of the nobles, he was condemned to inaction.

The Hungarian kings were much more favorably situated. St. Stephen did not give the dominions at his disposal to a few great nobles, but dirided them among a number of smaller men. These dwelt near together, and were under the eyes of the king, who could see to it that they discharged the duties in consideration of which they had received lands and privileges.

The bulk of the military power was supplied, not by a few of the most powerful subjects, but by a large number of subjects who were less influential, and less able to shirk their obligations. The Hungarian nation, moreover, was less far removed from the nomadic condition than the English, and the greater part of the people were familiar with arms since peaceful occupations were not so general as in England. Thus the Arpád kings were strong, though they had not much money. Lilie the 


\section{THE CHARTERS.}

expenses of the royal household, and of the administration of justice, the expense of warfare was largely met by payments in kind. In England, on the other hand, the king could not be powerful unless he was wealthy.

When public service is compulsory, administration and defence can be conducted without very much pecuniary sacrifice, but foreign warfare demands the expenditure of large sums of money.

The different situations in the two countries demanded different policies. The English lings needed money above atl things, and they accordingly revived the ancient rights and customs by means of which the old Saxons kings had raised money from their subjects, and which enabled the great feudal lords to demand money from their vassals. Taxation was gradually imposed upon all. The powerful feudal nobles, who could best have offered resistance to it, resigned themselves to the situation. They would naturally have liked to escape the obligation, but they preferred paying a tax to carrying on warfare at their own expense. Since the greatest nobles had to pay taxes, no one could expect to be exempt.

In Hungary, on the contrary, the interests of the king did not demand that taxes should be levied for the purposes of war. The few denarii, which at first were paid by all freemen, were so small a tax that the king could remit it without emharrassing himself. Perhaps it was even more profitable for him that the nobles should assist him in reacquiring the estates which had been alienated, than that the old taxes should be continued.

In any event the satisfaction to which the remission of the tax gave rise, atoned for any financial loss.

These circumstances explain why universal taxation was maintained in England, while it ceased in Hungary, and why the right of imposing taxes was reserved to the national council in England, and not in Hungary.

England suffered much from excessive taxation, which bore heavily upon all orders of the community, so it was only natural that Magna Charta should deal with it. 
Ancient tradition and public opinion were opposed to the levying of taxes without consulting those who had to pay them, and Magna Clarta gave expression to this opinion.

In Hungary no similar law was passed, because taxation was more irregular, and did not fall at all upon the more powerful nobles.

It was the different situation which made superfluous in Hungary those enactments which the state of affairs in England rendered necessary, and which are now seen to be so valuable.

'The detailed history of the origin of the Golden Bull is unfortunately unknown, but from its contents we may conclude that, as in the case of Magna Charta, all classes combined to bring it into existence.

This is shown by the fact that the Bull defends the interests of all, and deals with the demands of all.

It was probably the united strength of the nation which compelled King Andrew to yield, but it is likely, also, that the crown-prince, Béla, played a prominent part in the transaction. Who was so well fitted as he to harmonise with the king's interests a movement directed against the king? His situation linked him both with the king, and with the parties opposed to him.

Like the other princes, he was dissatisfied with his father's rule, yearned for power, and was anxious to ascend the throne. Having devoted all his energy to the augmentation of the royal power, he must have found it painful to see how his inheritance was being squandered by his father. After the issue of the Bull, the rupture between father and son became open.

It is reasonable to suppose, therefore, that Béla stood at the head of the party of reform, and this is indicated by the circumstance that his rights are dealt with in a separate paragraph of the Bull. In that party it was probably he who represented the interests of the State as contrasted with those of the various classes of the community. 
The backbone of the oppusition to the king consisted of the lesser nobility or gentry, as is shown by the fact that the leading motive of the whole Charter is the emphasising of their rights. Probably the higher nobles were not opposed to the Bull, for they were possessed of such power that had they placed themselves in opposition to it they must have provoked a conflict which would have left some trace. The Bull was not directed against the nobles, it only sought to hinder some of the more powerful of them from using their power against the public weal.

In declaring that the sons or brothers of nobles holding high offices and dying in war, are to be adequately compensated by grants of land, it openly favours the great. There is not one clause in the Bull which could offend the higher nobility by conferring exceptional privileges on the lesser nobles, as was attempted during later class contests. On the contrary, the clause empowering the Palatine, the Ban, and the Court Judges of the King and Queen to unite several dignities in their own persons, and also the clause entrusting the Palatine with the execution of the law, seen to indicate that the higher nobles were powerfully represented in the movement. The Palatine must have been a dominant personality among the reformers, for the temper of the age leads us to suppose that it was not any legal consideration, but the confidence which they reposed in him, which led the people to seek in him a support of the law. Probably the only opposition to the Bull came from those who profited by the king's prodigality, and who unlawfully held some of the crown estates; all others were driven by community of interest into the ranks of the reformers.

Thus the Golden Bull appears to have been the fruit of a national coalition, and in this respect also it resembles Magna Charta, with the difference that in England the pivot of the movement was the aristocracy, while in Hungary it was the gentry.

The royal power had preserved the unity of the nation 
during two hundred years. The various orders of the people were united in service of the State.

They had learned to work together, and to pursue one common aim. Thus it was possible, alike in England and in Hungary, for a coalition embracing all classes to be formed. This possibility was one result of the kingly power. In France such national action was rendered impossible by the disintegrated condition of the nation.

In England, the coalition was called forth chiefly by the violence of the king, while in Hungary it was due to the powerlessness of the monarch to maintain order in the realm. But in buth countries the national action was directed to the same end, namely, the more accurate definition of the legal relations between king and people, and in both countries the coalition was certain to succeed, because the united nation was stronger than the king. The mediæval monarchy, by maintaining the national unity, rendered possible such an opposition to itself as it was unable to overcome, and consequently was obliged to acquiesce in the development of a freer constitution. The king had to unite the various currents of the nation's life into a single stream, or they would have been unable to bear on their bosom the stately ship of the monarchy, but that stream became so powerful that the ressel could not oppose the current. Only in harmony with the popular will could the king attain any result. He had to reckon with the powers, which to some extent he had himself created, and which forced him in the direction of new aims.

The Golden Bull is a mighty national achievement, restoring the ancient national liberty. Its plan embraces the main interests of all the estates of the realm. In that respect it is unique, and ranks higher than Magna Charta. It does not disturb the harmony of national life by favouring one class or interest too much. Like the English Charter, the Golden Bull aims only at the restoration of ancient rights. 


\section{THE CHARTERS.}

These were great results, yet the question still remained whether what the nation had embodied in its laws would be realised in its life.

Both Charters summed up the achievements of the past in the direction of freedom. Both had been made necessary by repeated offences against the law. Whether these offences would cease remained to be seen. How. ever clearly the laws might be expressed, this expression did not guarantee their execution. Doubtless, the way was made easier to oppose injustice, but much remained to be done in order to make the letter of the law a living reality.

The best elements of the nation deroted themselves to this task during the years that followed. Great Charters consummate the work of the past, but at the same time set new tasks for the future. As links in the chain of ceaseless derelopment they mean both an end and a beginning. 


\section{CHAPTER VI.}

THE THIRTEENTH CENTURY. STRUGGLE FOR POLITICAL, POWER. VICTORY OF THE MONARCHY IN ENGLAND. EXIGGERATION OF FREEDOM IN HUNGARY. THE CENTURY'S RESULTS IN THE THO COLNTRIES.

The machinery for executing the law was primitive. Both England and Hungary acted in the spirit of the times when the emphasis was laid on the right of resistance. Since in England the more powerful nobles had extorted the Charter from John by force, and the leaders of the nobility were the masters of the situation, it was from their ranks that a Committee was chosen to secure the execution of the law, and to prevent by force of arms, if necessary, any infraction of it.

In Hungary, as all ranks had been concerned in the movement, it followed naturally that armed resistance became the right of every man of standing.

But neither the English nor the Hungarian method of defending the nation's rights could answer. The English method was dangerous because it enabled one party in the State to stop the wheels of government at any moment, and placed the king in an intolerable position of subordination. The Hungarian method was also dangerous, because it made the individual a judge of both king and law. Both ways were objectionable, because they legalised civil war, and made of it, though it should be the ultima ratio, the first means of the defence of popular rights.

No constitution has ever been built up without resort to arms. If this resort were absolutely impossible, free- 


\section{TH CENTLRY POLITIC:AL STRLGGLES.}

dom would be in danger, but it is a grave mistake to give it legal standing, and raise it to the rank of a system. Even during the Middle Iges it was a fault to plunge a state into civil war.

Moreover, both methods were insufficient, th: English, because it was merely transitory, and the Hungarian, because only the strong could employ it, and because it made impossible any restriction of the nobles' power as well as the restoration of the king's authority.

The unsatisfactory nature of both methods was quickly realised. In England the clause concerning the right of resistance was never renewed, and after a time its place was talien by the right conferred upon the Church of excommunicating those who broke the law.

In Hungary the Golden Bull haid upon the Palatine the responsibility of seeing that the law was observed. There too, in time, the clause concerning resistance was replaced by the right of excommunication.

These means, however, led to no result. Mher were either ineffectual, like the control exerciscd by the Palatine, or clse the power was placed in the hands of an agency, which, while ready to tand up on behalf of its own interests, like the Churcl, was not inclined to interfere when others were wronged.

All this led to the conviction that the constitution needed to be changed in order that the privileged classes might govern, and it was lhis endeavour to reform the constitution which shaped the history of the latter end of the thirteenth century.

While the Charters had endearoured to defend the rights of the different classes against the central authority, greater importanct: began to be attached to the development of the constitution. The nation came to see that private rights could only be secured by the possession of effective public rights. Experience forced upon both nations the need for a reform of the constitution, but just as the Charters had been somewhat different 
in the two countries, se the reforms effected were different.

In England, the Charter had been wrested from a reluctant kingr, and if is provisions were not complied with, the hindrance lay generally in the hostility and the open or secret opposition of the monarch. John had accepted the Charter, but tried to evade it. His son, IIenry 11I. wished to free himself from it. Accordingly, the barons carried on an open struggle with the king for power. It was their conviction that only through their power could the Charter be made effective. In the monent of victory great plans were conceived, and the barons made an effort which greatly aided future developments.

They endeavoured to confer all the powers of the king upon the nobles. .1l that England attained to in the nineteenth century, the barons tried to gain, not, however, for the nation, hut for themselves. 'The people had not yet reached that maturity which would have enabled them to manage the affairs of the State independently. Without a real king, the constitution could not be defended against the nobles, either by the authority of Parliament, or by laws, w by the economic strength of the lower classes.

Progress is often thecled by a power which has developed in the service of progress. Those who have sained power in the struggle for freedom have often used that power to extinguish freedom. This happened in the case we are now considering. The nobles, while fighting at the head of the nation in the sacred cause of liberty, acquired such power as tempted them to misuse it. Strong nations, however, can prevent the advantages derived from the past from becoming the bane of the future, and England would not sacrifice her liberty for the sake of those who had formerly fought for that liberty, but now opposed it.

Luckily, the intentions of the aristocracy were clear enough. The nation could easily see that the humiliation 


\section{TH CENTURY POLITICAL STRLGGLES.}

of the monarchy would not mean liberty for all classes, but would merely establish an oligarchical tyranny.

The aristocracy was accordingly left to itself. It was unable to achieve the end aimed at, and failed in all that would have endangered the welfare of the country, yet the struggle was not fruitless. Edward I. destroyed the barons, and brought victory to the monarchy, but he accepted such of the reforms advocated by his adversaries as harmonised with his own interests.

In former times, Charters could be gained only in the case of a weak ruler, so that the weakness of the king was a piece of good fortune for the nation. But after Henry 1II. the king's weakness was a misfortune, because power was grasped by the oligarchs, and a reaction was sure to set in which threatened all the wreatest institutions. Had the power of the monarch declined too much, the same evils would have made their appearance as existed in France.

Edward warded off the danger. His reign was a fortunate thing for England. When he ascended the throne his interests were identical with those of the nation, His own welfare demanded that he should respect the rights defined in Magna Charta. The king's power is really much greater if he does not transgress the limits assigned to him by law, and if he wins the confidence of the nation, than if he fights for unlimited power and estranges the hearts of his subjects.

But Edward's interests did not allow him to comply with the extravagant demands of the barons-demands which they had been encouraged to make by the weakness of the king's predecessor. To yield to these demands would have been to rob the monarchy of all reality.

The king's interests were identical with those of the nation, while the aims of the barons imperilled the nation's unity. Edward's great power, which brought him victory, served also the interests of his subjects. The nation, luckily for it, was passing through one of those rare moments when the right man was in the right place, one 


\section{DEVELOPMENT OF HLNG MRIAX LIBERTY.}

of those critical moments when one man can do more than an even greater man could do at another time.

Edward carried to completion the task of the thirteenth century. He harmonised the aims of the two parties which before him had stiffly oppesed each other.

The opposition of the monareh to the people's freedom had placed the country in a difficult situation. Fdward I. was the first ruler who reconciled these interests, and who raised himself above party considerations. (On the one hand, he preserved and atumented the strength of the monarchy, without which it could not accomplish the tasks assigned to it, while on the other hand he left room for so much freedom as was essential to harmony.

In Hungary, as we have seen, the Golden Bull was designed to adjust the relations of the various Estates of the realm.

The authors of it paid due regard to the king's authority, for they realised that freedom was impossible in the absence of a strong king. The stubborn strife of king against people which caused so much unrest in England, was unknown in Hungary. There the interests of king and nation were not opposed to one another, and the absolute victory of the party of reform would not have proved a blessing to the country. Everything depended upon the question whether such institutions could be established as should assure both the power of the monarch and the freedom of the people.

The power of the oligarchy had to be broken, and the rights of society guarded against the arbitrary will of the king. One of these results could only be achieved under a strong king, while the other seemed impossible if the monarch was powerful.

The Bull could not accomplish what was expected of it. It gave the king the right to take possession of the royal estates which had been appropriated by the nobles, but, on the other hand, it conferred upon indiriduals the right of resistance to the king's orders. The privileged classes contradicted themselves. What they created with 


\section{TH CENTURY POLITICAL STRLGGLES.}

one hand they destroyed with the other. 'They gave a mortal wound to the authority they desired to set up. The difficult problem confronting the nation could only be solved by a policy similar to that pursued by Edward I.

Béla IV. (1235-1270) set himself the task of finding a solution. He threw himself with ardour into the most urgent part of his task, the suppression of the magnates and the restoration of the lingly power. For this great work he possessed all the necessary qualities, and he would probably have succeeded in warding off the danger of the oligarchy without depriving the bulk of the people of their rights, and in harmonising a strong rule with the freedom demanded by the spirit of the age, had not the Tartar invasion fallen upon the country like a thunderbolt. The disastrous battle on the Mohi plain (12+1), where the Hungarians were utterly defeated, put an end for the time to the king's actirity.

The victory of the Tartars was largely due to the small number of fortresses possessed by the Hungarians.

This state of things had to be altered, even at the risk of undoing the work accomplished by the king in the direction of reducing the magnates to subjection. When the Tartars retired, two years later, the king built fortresses wherever he could, or else obliged the towns or the nobles to do so. To enable them to do this, it was necessary to proride them with funds, so the king, who had acquired considerable power by taking possession of lands which former monarchs had alienated, now gave them away again liberally. He created a powerful nobility, which should break the power of the existing one.

Politics often deal hardly with a man. If he desires to achieve a certain object, and to serve the interests of his country amid changing circumstances, he has often to abandon his favourite ideas.

Béla granted to the Frangepans, and to the Counts of Brebir, rights of a lind to which Hungarian public 


\section{DEVELOPMENT OF HUNGARIAN LIBERTY.}

opinion had always been hostile, as to something foreign and dangerous." "The expression, "barons of the land" was then first introduced into the legal code. Dominion cver some counties was conferred as a permanent right upon certain barons, who were directly responsible to the king. Had Béla been succeeded by strong kings, this nobility might have proved serviceable to the country; but the premature death of Stephen (1270-1272), and the weakness of Iadislas $1 \mathrm{~V}$. (1272-1290), led to a great increase in the power of the magnates. The Csák family and the Counts of Németujvár attained a position quite unsuitable for subjects. The unity of the nation became endangered, while the wars and robberies of the magnates impoverished the people, and made peaceful development impossible.

The border counties fell entirely under the government of some of the more powerful magnates.

This was the danger which the Golden Bull had been designed to ward off. Now that the danger was present, the struggle had to be begun again. The work which had been interrupted by the Tartar invasion had to be carried to completion. The bulk of the gentry, feeling themselves equal to the magnates, were enthusiastic for national unity, and placed themselves in opposition to a development so discordant with the Hungarian genius.

The gentry, although they had of late been somewhat kept in the background, had preserved their self-esteem and had not abandoned their rights. Although the law of 1267 introduced some distinctions between the lesser nobility or gentry, and the barons, yet in regard to important rights, this law did not create any lines of division between the various classes of nobles. The instincts of the gentry, which had proved so useful in the early years of the century, were still vigorous, and the king could reckon upon finding in them a powerful ally, if he saw

*The County of Modrus was given in the Frangepans. and the County of Brebir to the Subies family, as hereditary possestione forer. 


\section{TH CENTURY POLITICAL STRUGGLES.}

clearly his task, and turned against the usurping magnates.

Andrew III. (1290-1301) saw what he must do, and set himself to do it. Ladislas IV. had felt the necessity of allying himself with the gentry, but he was not sufficiently earnest and persevering to attain any important result, so the task was left to Andrew-the same task which, about the same time, was so brilliantly performed by Edward I. in England, that, namely, of restoring the dignity of the State. Andrew did not hesitate, but at once revived the alliance with the gentry, and formed a coalition directed against the oligarchs, similar to that which had led to the issue of the Golden Bull.

The century closed amid struggles like those which its commencement had known; but now the difficulties in the way of success were greater than formerly, for the oligarchy had grown stronger. A farourable issue was only to be hoped for if the king, gathering around him the bulk of the nation, should make a determined assault upon the magnates, leaving the question of extending the people's freedom until after he had won the victory. That was what Edward I. had done in England. His conflict with Simon de Montfort was terminated before he ascended the throne.

Andrew, however, was not such a resolute man as Edward, nor had he so free a hand as the English king. As a result of old traditions, he did not stand at the head of a party deroted only to the king's interests. His adherents followed in the footsteps of those who had given birth to the Golden Bull. For many years they experienced the bitter truth that the king did not respect in practice the privileges which he had acknowledged in theory, and they wished to remedy this as well as to prevent the transgressions of the magnates. The difficulty which had confronted the nation a century earlier still pressed for a solution, namely, that to restore order it was necessary to augment the king's power, and yet, in order to defend the people's rights it was necessary to 
restrict it. The gentry endeavoured to secure the results they desired by the laws of 1291 and 1298, and it is worth while to consider for a moment these achievements.

In 1291 it was enacted that counties were not to be given away as hereditary possessions, and that the grants which had been unlawfully made were to be revoked. It was also declared that the lesser nobles or gentry need not follow the barons to war without pay; that the barons were not to give shelter or protection to any condemned person, and that their fortresses were to be destroyed.

In 1298 a still more severe law was passed against the usurpers. The Parliament which passed it was held in the absence of the magnates.

Severe penalties were attached to every infraction of the law. Those who had wrongfully taken possession of lands were to restore them within three months, under penalty of confiscation of property, excommunication, and exclusion from the ranks of the nobility. If the king could not overcome rebels by means of the forces of the country itself, he might apply for foreign aid. The barons who forced any memher of the gentry to render military service were to be severely punished. Only money coined at the royal mint was to be used, and any persons minting money were to be deprived of their estates.

These laws met the public needs, yet the execution of them could only be secured by a strong central power, for strong forces were opposed to them.

The gentry, however, either because they did not trust Indrew, or because they were as anxious to gain influence for themselves as to restore order, did not increase the authority of the king, but endeavoured to seize the executive power themselves. In 1291 it was enacted that the king should be guided by the adrice of the noble class in the appointment of the Palatine and the Treasurer. This attempt to gain a roice in the appointment of prominent officials was not entirely novel, for in 1231 it had been resolved that when the country 


\section{TH CENTLRY POIITIC.ML STRLGGLES.}

demanded it, a bad Palatine should be dismissed, but no law had tied the hands of the king in the actual filling of such posts until 1291 .

This restriction of the king's power did not make his task easier, nor did it strengthen the extcutive.

In England also, a roice in the election of the principal officials had been demanded, not however, by the ling's adherents, but by his adversaries; nor did Edward consent to the proposed reform, for he saw that his task would be impossible of achievement if he had to choose his instruments in accordance with the will of others. It was unfortunate for King Indrew, and yet only the natural outcome of the situation, that in Hungary it was the king's allies who made the demand which in other countries was made by the king's opponents. 'The gentry began to make their influence felt in the provincial administration also. It was proclaimed by law that County Lieutenants were responsible to the Diet, and that they would be rewarded for their merits, and punished for their misdeeds.

The conception that every one concerned in the administration should be responsible to one central power, the king in Parliament, was great but barren. Administration could not be efficiently conducted even at the present day if the County Lieutenants had to justify their proceedings to a Council held in the presence of the citizens en masse. The liability to account made strong government in those times simply impossible.

The County Lieutenant, hampered in this way, had in addition, four noblemen appointed to attend him, whom he was obliged to consult before deciding in any case brouglit before him. When the Palatine travelled from county to county to administer justice, the lieutenant and lis four nobles had to be present at his court, so that if he should pass an unjust judgment, they might apply to the king to annul it. They had the right of veto.

In 1298 this control was carried still further. 


\section{DEVELOPMENT OF HUNGARIAN LIBERTY.}

Four nobles were appointed, in addition to the ling's commissioners, to investigate every case where there was any suspicion of property having been illegally acquired. The whole state was placed under the dominance of the nobles. It was proclaimed that the Diet was to meet annually, and that every nobleman had to put in an appearance there, or incur certain penalties. The Diet's control was extended to every member of the executive'ven to the king himself, who could not act without the assent of a council. It would seem as if the institution of a responsible ministry had already made its appearance, though in a different form. This Council was entirely under the influence of the nobility, as it was from that class that its members were elected by the Diet.

The two laws of 1291 and 1.298 embody principles of very great importance. They did much to further the cause of liberty, and were so much in advance of the age as to awaken our admiration. Had the problem to be solved been merely the curtailment of the royal power, and the participation of the bulk of the nation in the work of administration, they might have been successful.

It is interesting to compare these efforts with those of the English barons during the period between Magna Charta and the accession of Edward I., to compel the king to respect the law. The English reformers also desired to appoint a committee to control the king, but no one was bold enough to declare that any acts of the king performed without the consent of the committee were invalid. Only the Hungarians conceived that plan, which later experience fully justified. In England the members of the committee over and above those nominated by the king were chosen only by the harons, while in Hungary the Diet and the entire class of nobles claimed that right. The English committee not only took over the royal power but stood in the place of Parliament (1258).

In Hungary the National Council was maintained, and had to be convened annually. The control of the 


\section{TH CENTURY POLITICAL STRUGGLES.}

whole administration was in its hands, so that it became the most important institution of the State.

While the English efforts really served the aims of the oligarchy, and placed the power in the hands of a few families, the Hungarian laws endeavoured to establish the autonomy of the whole nation. But in Hungary also the reformers overshot the mark, and tied the king's hands so much that a reaction was inevitable, and the final result was the same as in England. The constitution, founded upon the participation in administration of the bulk of the people, was not in harmony with existing conditions.

The law had given equal rights to all members of the noble class, yet the actual differences in the power of individuals were vast. How could an ordinary noble have equal rights with a Matthew Csák, when the one was able to equip 8,000 soldiers and carry on war on his own account, while the other had nothing but his sword. To make the new constitution a reality, it was necessary that the power of the oligarchs should be broken. This duty, by law, fell upon the ling. The country's future depended upon whether the king could be induced to make the effort. The theoretical excellence of the new constitution was of no avail if the oligarchy could not be crushed. And there was little hope accordingly for the constitution, for a king who was willing to suffer his rights to be clipped by the people was not the man to subdue a powerful baronage. A task which he could not accomplish when his power had been greater, was still more difficult when he found himself under the tutelage of the masses.

Andrew's death soon put an end even to the effort, and now that the last of the Arpád kings was dead, the country was confronted by a great problem. The work commenced in the thirteenth century was still unfinished. What could the country look for in the future? Could a free constitution be harmonised with her other aims?

Before, however, going further, we must cast another glance at the important events of the thirteenth century. 


\section{DEVELOPMENT OF HUNGARIAN LIBERTY.}

By the end of that century England and Hungary had made great progress towards securing government in accordance with law, but England had achieved the greater result.

In both countries the effort had been made to give Parliament the leading place among the organs of State life. In Hungary the morement proceeded on lines which were theoretically more correct than those followed in England, and yet the result was not so satisfactory.

In England, both the king and his opponents adopted a selfish attitude, yet it was found possible to harmonise the conflicting interests, and reach a fortunate dénouement.

It is to be ascribed to the clear and powerful thinking of a great man that the monarchy did not abuse its victory, but by fulfilling the just demands of its adversaries, strengthened its position. The long struggle had shown clearly that neither party could hope to gain an absolute triumph over the other. Edward I. realised this, and created a constitution which was of the nature of a compromisc, and which met the needs of that age, and formed an excellent foundation for future generations to build upon.

In Hungary the goal which ling and gentry set before them was an excellent one, but they were unable to find the road to it. In theory they were in advance of others, but in practice they lagged behind. Edward, above all things, was strong enough to conquer his adversaries, while Andrew was not, and after his victory he modified the constitution to the extent which the state of development of the country and the distribution of power demanded. The Hungarians, on the other hand, created a constitution which was too much in advance of the age to endure. The more exalted political ideals led to less permanent results than the compromise arrived at between clashing extremes. Practical necessity provided a better solution than theory.

Between the English monarch and the nobles, the 


\section{TH CENTURY POLITICAL STRUGGLES.}

power was dirided in such a way that each obtained that field of activity best suited to his capacity.

Edward declared that all matiers of common interest should be decided in common, and thus accepted the principle which is the foundation of constitutional government. He placed the united will of king and Parliament above his own sole will, and assigned to Parliament such functions as, if well discharged, must make it the greatest power in the State. It is true that in practice this theory was often ignored, but the fact that the king had enunciated it was in itself a great stride towards freedom.

Parliament had the right of voting war taxes, and this alone was enough to give it importance. On the other hand, Edward retained sufficient power and authority to enable him to perform again the services which he had sendered to the national cause in the past.

The executive power remained in his hands; the principal offices were filled by his appointment, and he was strong enough to keep the great nobles in order, and to maintain peace throughout the realm.

At the end of the thirteenth century the monarch's power could not place the achievements of Magna Charta in jeopardy, yet it was great enough to make the country considerable in the eyes of the outside world, and to maintain the national unity. England had a comparatively free constitution, and yet the executive power had not been weakened to such an extent as would make it inadequate to its task.

Hungary did not reach such a favourable result. There, two conflicting forces faced one another-exaggerated liberty and a strengthening oligarchy.

The great question which had been agitating all men's minds had been that of the distribution of political power. In England everything seemed to turn on whether Edward or Simon de Montfort would conquer, while Hungary's fate appeared to depend upon whether or not Andrew would triumph over the oligarchy. As time went on, however, the importance of these conflicts 


\section{DEVELOPMENT OF HUNGARIAN LIBERTY.}

faded away. In England, and a few decades later in Hungary under the Angevins, the great nobles were forced to recognise the monarch as their master. The wounds caused by former strife were healed, while other events, at first regarded as of less importance, made their influence felt more and more.

As has already been pointed out, the English reforms led to happier results than the Hungarian efforts, but that cannot be ascribed merely to the superior wisdom and foresight of English statesmen. Eren the greatest statesmen work for the present, and spek to meet the pressing needs of the moment. It is rarely possible to judge whether a law or institution which is good to-day, has vitality enough to enable it to serve the nation's interests centuries hence. Institutions which have struck root deepest, and proved most permanent, have rarely been originated with a view to the important part they were to play. It is very largely a matter of chance whether an institution which meets present necessities can also satisfy the unknown needs of the future.

We have already seen that in England the more hurdensome nature of taxation led to that country's being much more advantageously situated than Hungary in regard to civil rights.

In Hungary the new tasks of Parliament were entrusted to the old organisation, while in England, largely owing to the state of taxation, the organisation itself was modified and improved. Magna Charta had granted to every immediate rassal of the king the right of attending the National Council, the more important to be summoned personally, and the less important in general terms.

Simon de Montfort conceived the idea that other elements of the nation should be represented in Parliament besides the baronage, elements which had of late grown in importance. Every borough was empowered to send two deputies. Edward accepted this principle of representation, and left the election of deputies to the counties and the towns. Since that time the election of representa- 
tives has remained one of the country's permanent institutions. Without the necessity for any law altering anything in Magna Charta, the national council was slowly transformed, and the places of those who had been summoned as vassals-in-chief of the Crown were filled by.the elected representatives of the counties.

The importance of this alteration is incalculable. The place of the former crowd, which could never be relied upon, was taken by a body which could be summoned and kept together for a fairly long time, and which, on account of its smaller numbers, was capable of serious work. Only a body thus constituted could grow into such a power as the English Parliament became.

The ancient system had been hased upon the privileges of one class, and that a class which had been gradually losing the political importance which it possessed in Norman times, while the new system enabled the State to be represented by all the elements which were occupied with the serious work of the country. The consequences of this reform were never contemplated by its authors. Simon de Montfort and Edward I. merely acted under the pressure of necessity, and it was necessity which perpetuated the new system. Several classes of the population supported de Montfort. It was his interest to ally himself even with the poorer classes. It was impossible, however, that all of these should assemble in vast masses, and this suggested to the Earl the idea of keeping in touch with them by means of their representatives. As the less important nobles among the vassals of the Crown, who had in former times been summoned by a general invitation to the king's council, were linked by community of occupation to the subordinate vassals, and to the freeholders, and as, moreover, their fortune and education were similar to those of the latter classes, it was natural that in the matter of the Council they should be treated similarly, and that when representatives of these classes were invited the general invitation to the direct vassals of the Crown should cease. 


\section{DEVELOPMENT OF HUNGARIAN LIBERTY.}

How was it that the plan of representation, suggested by momentary expediency, became permanent? It was because it was found to be inevitable. The new system supplanted the old, because it alone was adequate to deal with the more frequently recurring need for taxation.

While the chief business of the Council was the discussion of political and administrative matters, the old system was fairly successful. It was quite sufficient if the leading nobles put in an appearance, together with such of the lesser nobles as were sufficiently interested in politics to he willing to make the sacrifice involved in attending, and the presence of the others was unnecessary.

But directly taxation became a pressing problem, the whole situation changed, for the old system had long shown itself incapable of dealing satisfactorily with 1 t. The council could only dispose of one part of the nation's wealth, that namely, in the hands of the vassals of the Crown. Public opinion was strongly in favour of the principle that those who pay should have a roice in determining the taxes. Magna Charta had not given the council any right to vote other taxes than such as fell upon their own class. It was a question also whether those vassals who had been invited to the council, but had not attended, were obliger to fall in with the decisions arrived at in their absence. The council had no power to impose taxes upon the towns, the subordinate vassals, or the freeholders. It was frequently necessary for the monarch, therefore, to discuss the question of taxation separately with the various elements of the nation, in different and sometimes distant localities

Directly these elements were represented in Parlia. ment, the situation became much easier for the king. Taxation could be decided upon at one and the same time and place for the whole nation. The electoral system created a body which could speak in the name of all tax-payers.

The electoral system was favourable to the king, but the noble class also was better off than under the old 


\section{TH CENTURY POLITICAL STRUGGLES.}

régime. Every element of the nation was able to exert some influence on public affairs, without having to bea: the burden of personal attendance at the council.

In Hungary, there were some cases of the election of representatives, but, unfortunately, the system was not able to establish itself. The reason is that the circumstances which made an elective system acceptable in England did not exist in Hungary. The frequent summoning of the council was not necessary, as the State could do without its co-operation. Attendance at the council, therefore, did not become an intolerable burden. Nor did the bulk of the nation feel the necessity of taking part in every meeting.

The council chiefly dealt with those great political questions to which lesser men are generally indifferent.

Moreover, such men were not confronted in Hungary, as they were in England, by the dilemma that if they attended they were involved in great trouble and expense, and if they did not attend they could not defend them. selves against the imposition of unfair burdens. Then, too, more men would have lost by an electoral system in Hungary than would have gained by it, whereas in England the reverse was the case, for in England, on'y the king's direct vassals were members of the council, and when, therefore, the counties sent representatives, the lesser vassals of the king were indeed losers, but the other elements of the nation acquired new rights. The English council was so constituted that only by a radical trans. formation could it incorporate such elements as were becoming increasingly important, for the direct vassals of the Crown did not increase in number. In Hungary, on the contrary, the noble class could easily be increased, and already in the thirteenth century, it embraced the majority of the wealthy, intelligent, and respected members of the community. There was, therefore, an easy access to the national council, which all members of the nobility were entitled to attend. Without the need for any radical change, the council could include all who 


\section{DEVELOPMENT OF HUNGARIAN LIBERTY.}

were worthy of a place in it. It was a result of the steadily pursued policy of the Arpáds that the nation, so far as inteligence and political infuence were concerned, became more anrl more identical with the noble class. The king needed the support of the nany against the few powerful oligarchs, and he, therefore, extended the borders of the nobility, giving all the better elerrents of society access to it. Accordingly a system of election would have restricted the rights of the large and important class of the lesser nobles or gentry, as they were later called.

The transformation effected in England was possible. because the county, with its shire-moot or county court, was an old and firmly-established institution, which had been taken over by the Normans from the Inglo-Saxons. The shire or county was a unit for fiscal and military purposes. The county court was a representative body' which exercised important functions, and brought together the various elements of society within the county.

In Hungary, the county system had not gained so strong a hold upon the mind of the mation, but was only just beginning to be a centre of political life. The provinces were not sufficiently well organised to allow of their sending strong arid really representative men to the council.

In one other important point, also, England acted with greater sagacity than Hungary. Simon de Montfort, in order to acquire strength for the impending struggle, invited to Parliament representatives of the towns which faroured his party, and this practice persisted after his death. Why was it that in Hungary access to the council was not granted to the burgesses of the towns?

In England the towns were of great importance, and their burgesses were wealthy, and paid heary taxes.

Under the Norman and early Plantagrenet kings, the amount of contribution from each town had to be settled locally by discussions between the king's officers and the towns, but when Parliament became the recognised instrument for roting taxes, it became natural to discuss 


\section{TH CENTURY POLITICAL STRUGGLES.}

such matters with the representatives sent by the towns. It is true that these representatives were not at first considered equal to the other members of Parliament. They were only invited because of the taxes they were to contribute, and they had to rote these taxes independently of the rest of the council, but in time they fused with the others, and their real importance secured them equal rights.

The importance of these erents only became manifest in later times. As the representatives of the counties were sent for the same purpose as those of the towns, the similarity of the part they had to play bound all the elected representatives together into a group distinct from the lords. From them the House of Commons as we know it to-day developed. In time the conception of common rights created a lind of unity among the middle classes. The esprit de corps prevailing among the elected representatives extended to their constituencies. The power possessed by the House of Commons was largely due to the fact that it was baclied up by a strong and united middle class.

Of all these results but little was foreseen by the authors of the representative system. Their desire had merely been to get in the taxes in the easiest manner. Yet the merit was theirs nevertheless. No statesman can be expected to do more than meet the needs of his own times. If a statesman is too much given to hazy dreaming of the future he is not likely to accomplish much.

Unfortunately the conditions prevailing in Hungary during the thirteenth century did not render it necessary for burgesses to be invited to Parliament. The comparatively uncivilized inhabitants of the country had not founded important cities before the coming of the Hungarian race. Nor did the nomadic Magyars immediately do so. It was not until the thirteenth century, and more particularly the time of Béla IV., after the Tartar invasion, that any great attention was given to town building. Even then only the 


\section{DEVELOPMENT OF HUNGARIAN LIBERTY.}

first steps were taken, such as had been taken by the English as early as the reign of Henry II. All that the settlers in the towns needed as yet were certain local privileges. They were mostly foreigners, who took no very keen interest in the welfare of the country, and as the budget was not dependent upon taxation, there was no necessity on that account for their representation in Parliament. Had there existed a politician who was able to see with a prophet's eye the future importance of the towns, and who endeavoured to secure a place in Parliament for the burgesses, his effort would have been unsuccessful. The reform of the English Parliament was brought about by the urgent needs of erery-day life. At first it was because of the French wars that the king continually needed new taxes, and so he gathered round him the chosen representatives of those who paid the taxes, but in doing this he was creating an institution eminently fitted to safeguard the rights of the nation.

The situation in Hungary was widely different. There was no continual need of fresh taxes. St. Stephen did not restrict the national council so much as the Norman kings did. The existing institution had not been proved by experience to be utterly inadequate, and no radical reform appeared to be called for. Society, again. was not so well organised as in England, for the nation was young.

The Normans had found a well-developed AngloSaxon kingdom, and they maintained many of its social and governmental institutions. Arpád, however, found nothing of that kind in the country which he conquered. His followers were so different from the primitive inhabitants that he could make no use of any existing institutions, and accordingly destroyed them.

The conquerors themselves were not so civilized as the Normans. They did not bring from Asia the customs and traditions best fitted for a nation dwelling within welldefined boundaries. The Hungarians had first to form the right conception of a state, and to adapt themselves to it, 


\section{TH CENTURY POLITICAL STRUGGLES.}

so that during the thirteenth century they had still to create the machinery which in England had long been working. It was then, however, that the Hungarian counties were formed into autonomous bodies, and the towns also began to acquire self-government.

In this direction, the achievements of the thirteenth century proved more important in Hungary than in England. In the original Hungarian community there were two important classes-the dwellers in the fortified towns, and the free nobility. The first were subject to the county lieutenant, who was supreme in military, judicial, and general administrative affairs within the county. The free nobles were quite independent. They administered justice within their own domains, and were in no way subject to the king's officials, the lieutenants of the counties. The new county was built upon the ruins of this dual system. The wealth of the community became more distributed. The clan system gradually broke down, and the county organisation absorbed most of the nobility. The primitive county system had for some time been decaying. The pecuniary and social standing of the population of the fortress towns had become more and more unequal; some had sunk to the level of serfs, some again, by good luck or merit, had risen to the ranks of the gentry or lesser nobility. It was fatal to the old organisation that enor. mous tracts of crown property, together with the power they gave, had drifted into the hands of the great nobles. The pride of the rest of the nobles, however, could not endure this usurpation by a few great lords of power which ought to belong to the king and the people, so king and gentry allied themselves against the oligarchs. This was effectuated in the provinces by the dwellers in the fortress towns, which had formerly been the strongholds of the great nobles, and the wealthier gentry, entering into direct touch with the monarch, and ignoring the county lieutenant. In the second quarter of the thirteenth century the inhabitants of the counties began to gain autonomy. It was they who made wrong-doers feel the rigour of the 
law. The king invited the nobility of the counties to discuss with him matters of local interest. These nobles followed the king to battle under the banners of his grenerals.

It was at the same time that the county began to elect efficials. The office of szolgabiró (a kind of sheriff), the earliest county official, dates from that period.

When the counties, or when the gentry of the counties, gained more and more influence upon the county councils, a certain esprit de corps was certain to spring up. An organised whole somewhat resembling the English county was created, and in time this new organisation was able to recreate the national council, which had long reflected the general disorganisation of society, and to mould it into its own likeness.

Probably the new county system was the most important of all the achievements of the thirteenth century in Hungary. It was brought into existence by the necessities of the moment, almost unnoticed, yet it endured for centuries and has constantly remained the foundation stone of the constitution. 


\section{CHAPTER VII.}

\section{MONARCHICAL REACTION IN HUNGARY. THE ANGEVINS.}

The death of Andrew III. in 1301 put an end to a great historical process. The efforts to achieve the nation's freedom which the thirteenth century witnessed had not yet been crowned with success when the last Krpád ling died. The power of the monarch, indeed, had been restricted within such narrow limits that it became doubtful if it was sufficient to maintain the nation's unity, but the magnates on the other hand, in defiance of theoretical equality, had acquired such power as to become a menace to the nation. The extinction of the Arpád line was thereiore a tremendous blow, for it came at a time when the national unity was again in danger. The throne had to find a new occupant at the very time when it was least likely that so grave a problem could be solved peacefully. The existing order of things was tottering, and the country's welfare needed more than ever energetic and clear-sighted leading.

The free election of a monarch can easily give rise to great disturbance, especially in a country where the various elements are already in conflict with one another.

There were many related on their mother's side to the Arpád line, as, for instance, Wenceslas of Bohemia (1301-1304) and Otto of Bavaria (1305-1308), who were anxious to claim the throne. Who would not be captivated by the thought of wearing the crown of St. Ste- 
phen? The situation was made more difficult by the candidature of Charles of Anjou, which introduced a question of principle into the contest.

The question was not merély who should be king, but whether the Crown should be independent of the Pope, and there was also the important constitutional question whether succession should be based upon inheritance or upon free election. The threads had become so entangled that a peaceful dénouement seemed almost impossible.

The conflicts which occurred during the time of the "Mixed Dynasties" are generally ascribed to the fact that the principle of election was adhered to. It is true that the election of the monarch often proved the spark which set the fuel ablaze, but that was because the circumstances were so remarkably difficult. One of the candidates for the throne was supported by the Pope and by one of the most powerful forces in Hungary, the national church. Such a candidate could not be slighted, but neither could he be elected unanimously, because he professed principles which were repugnant to the people's strong national sentiment. The strife kindled in this way did not die down for years. No king was able to win the allegiance of the whole nation, and Hungary remained without any strong controlling hand. The important work of curbing the powerful barons was postponed.

Such of them as possessed a fortress and an armed force, or had influence as electors, were masters of the situation, and the rest, and particularly claimants to the throne, sought to curry favour with them. It seemed as if the process in which the whole nation had been concerned since the time of the Golden Bull would end in the triumph of the barons. The powerful national sentiment, however, warded off this danger.

Whether or not an institution is a vital part of the national organism can only be proved in a time of adver-

* See pages 25 and 26 . 


\section{MONARCHICAL REACTION IN HUNGARY.}

sity. The danger brings into activity the various forces which have fostered the growth of the institution. The danger in which the monarchy now found itself in Hungary summoned to its aid those powerful factors of the nation which found their interest in its welfare. The Hungarians had always been alive to the necessity of national unity, and the perception of this necessity became the determining motive of their conduct, and led them to give enthusiastic support to the king who had fought most strenuously for the throne.

Their maintenance of the nation's unity preserved the dignity of the country. They retained the right of free election $b y$ means of a happy compromise, and at the same time made peace with the Pope, without, however, submitting to any humiliation, thereby griving proof of their political sagacity.

Robert Charles (1308-1342) was left without a rival, and then, with the aid of the Church, he re-established order. The bulk of the nation was on his side and actively helped him. The alliance between king and gentry which had existed in the thirteenth century was renewed, but with one important difference. When the alliance had sought to achieve two distinct purposes, namely the fostering of popular liberty and the assurance of national unity, it proved a failure. It was unable to preserve internal order, and anarchy and lawless nobles inflicted terrible evils upon the country. Made wiser by this bitter experience the nation desired order and unity above all things, and it realised that it could only obtain them under a powerful ruler.

The gentry had been willing to support Andrew II. and Andrew III., but only in return for privileges and power to be conferred upon them. By the time of Robert Charles, however, they were content if the king would only save them from the powerful barons, who injured and humiliated them constantly, and whose tyranny was repugnant alike to their interests and their patriotic sentiment. 
The reign of Robert Charles was a reaction against the movement commenced in the thirteenth century in the interest of popular freedom. Like all reactions, it was called forth by exaggeration. Public opinion was startled by the process of national disintegration which was taking place, and sought safety in the power of the king, abandoning for the time the cause of liberty. This did not imply a permanent change in the sentiments of the nation, and that a race passionately devoted to liberty had been radically transformed into lovers merely of order. Moreover, the king was not strong enough to push his rictory to the uttermost.

The strength of a reaction varies with the magnitude of the evil which has created it. When in England, Edward I. stopped the process of disintegration, the evil had not grown very great. The people were attached to the king, but were not prepared to support him unconditionally, for they had not come to look upon weakness in the monarchy as a crowning disaster. They were devoted to the rights for which they had so often fought, and the king was obliged to treat these with respect. In France, on the other hand, the monarch was called upon to break powers which had made their ravages felt for centuries; the people yearned for order and unity at any cost, and were ready to endure absolutism.

The evil which the Angevin lings of Hungary had to stop, had attained to larger dimensions than in England, but was less than in France. Consequently, the reaction brought greater authority to Robert Charles than to Edward I., but did not make him absolute like the French king.

The Hungarian nation temporarily lost its confidence in the principle of autonomy. Robert Charles had no interest in summoning Parliament and in giving the nation a share in the management of public affairs. If the king transgressed the law it gave rise to little discontent, for he could safely reckon upon the gratitude and support of the people, if only he destroyed the strong- 


\section{MONARCHICAL REACTION IN HUNGARY}

holds of the robber nobles and restored order and peace.

The king acted accordingly. He was not one of those rare rulers who, without compulsion, offer scope for free institutions, but he manfully grappled with the task which confronted him.

As soon as the king had accomplished this task, the slumbering love of liberty awoke again. Long wars were not necessary; a short conflict was enough.

During the reign of Robert Charles the old spirit began to make itself felt. The bishops were the first to complain that the king did not summon Parliament. His talented son, Louis the Great (1342-1382) understood the temper of the people, and acting as a really great man, forestalled the outbreak of any disaffection and established harmony. The course of development continued its former trend. The old freedon-loving habits revived. The nation enjoyer one of those rare periods when a great man controlled it, not by force, but by the influence of a remarkable personality and the increasing dignity of the kingly office.

The king became the centre around which all else revolved. At the present day, such an increase of the monarch's power would be viewed with anxiety, even though such power, in the hands of a monarch worthy to rule, might be beneficent. No devotion to a king would condone the infraction of law and the neglect of institutions. To-day, when political violence is fraught with such colossal danger, and when respect for the constitution is the bulwark of a nation's liberty, the most fervent loyalty could not tolerate contempt for the law. But during the Middle Ages it was possible to vary the extent of conformity with the constitution which was demanded from the ruler, in accordance with his personality.

A really eminent king might rule despotically, but one in whom the nation had not much confidence was kept under the control of law. Louis the Great helped Hungary to develop the talents latent within her people to the utmost extent which the times rendered possible. 


\section{DEVELOPMENT OF HUNGARIAN LIBERTY.}

During his reign Hungary became one of the first powers in Europe.

What was the effect upon the monarchy of this prosperity under the Angevins? Robert Charles had not conformed to the constitution. Louis kept to the old forms, but he had such command over men's minds that his will always prevailed, just as had been the case with the other great kings, Kálmán and Béla III., who flourished before the time of the Golden Bull. This change was salutary, for it was essential to restore to the monarchy its strength and dignity, without which it could not do its work, and in the absence of which the cause of freedom must suffer. The work of the thirteenth century was completed by the Angevins. They brought the constiution into harmony with the requirements of that age, and succeeding generations dwelt beneath the structure which the Angevins had erected. The basis of their power was not their wealth or the military forces which were at their disposal independently of the will of the nation; nor was it the conviction that royal power has a divine origin, and that a nation's rights are merely favours bestowed by the king, which he has a perfect right to withhold, so that it is to the people's interest to be obedient. 'The nation did not lose its self-respect, and the exaltation of the throne was due, in the case of Robert Charles, to a conviction of its necessity, and in the case of Louis, to the great king's personality, his personal fascination it might be said, and to the wisdom of his policy. The people bowed before the will of the king because they saw that obedience to wise commands led to the happiest results, and because greatness in the monarch evolied spontaneous homage. It is easy to see that this relation of king and people did not mean permanent absolutism, for it could only last while the individual retained his superiority. Absolutism was an abnormal state of affairs during the Middle Ages. Only exceptional individuals dared to attempt it, and therefore it was not dangerous. It made its appearance during the most prosperous periods of a country's history. 


\section{MONARCHICAL REACTION IN HUNGARI.}

Those unhappy times were still far off when a contemptible weakling, if crowned king, could tyrannise over a nation and shape it into his own likeness. At the times of which we are treating the first condition of a monarch's power was one which unluckily cannot be made permanent, namely, his personal superiority. A strong king could educate and discipline a people without rendering it servile. The king was the first Hungarian citizen, but not the only one who possessed rights, and his rights were not more sacred than those of the nation. It was the will of the nation which had raised the king to the throne, just as, according to the common belief the monarchy itself had been instituted by the people. Selfrespect was not extinguished. Felician Zách avenged an insult to his family by a royal prince with his sword. He was not of those courtiers who were so plentiful in the days of Louis XV. of France, who left their sullied honour unavenged if the offender wore a crown.

The Angevin kings did not fortify the constitution by the creation of any new institutions, but they strengthened the old ones. Louis the Great performed a great service to the State when he revoked the laws of his father and of Andrew III., and restored the earlier laws. The laws of Andrew III. restrained the king in many ways, and a powerful personality like Louis the Great could not brook such restriction, but he summoned Parliament, gave the nation a share in the work of legislation, and confirmed the Golden Bull. That alone was a great achievement. His glorious reign showed posterity that the ruler over a free nation could be strong and his country flourishing. The part which Louis played in history was similar to that of Edward I. He carried to completion the reform movements of the thirteenth century. He sifted the experiments of earlier times, separating the laws which suited the age from those for which the country was not yet ripe. Edward and Louis both succeeded in establishing the new order of things created by themselves as the permanent organisation of their realm. With a few alterations 


\section{DEVELOPMENT OF HUNGARIAN LHIBRTY.}

their systems endured for enturies. But Louis' achievement was less perfect than that of Ledward.

As we have seen, lingland gave birth to beter institutions during the thirterenth century than these created in Hungary. Louis did not improse the public law handed down by his predecessors. In that field he gare no proof of his creative power, and that is a shadow upon his brilliant personality. For instaner, he did nothing to add to the prestige of Parliament, by drawing intes it new and important elements of the nation, or by re-organising it.

In the counties the . Ingrevins athiesed mucle greater results. The variens classes of the county pepulation were drawn more clusely together and develeped a keener sense of citizenship. The county meetings were convened more freguently. Louis used the countites ats means of keeping order. If there were any turbulent charaters in the district, such at robbers, it wats 10 be merntioned at the meetings of the county councih. The kins encouraged a wholesome spirit of relf-rowernment. Ile educated the butk of the sentry in politice, and gase them an organisation which enabled them to withstand the magnates.

The most original work of the Ingevin was in the direction of social and military matters. We have seen that they broke the power of the great nobles. vet they had no desire to create social quality. On the contrary, they endearoured to introduce the degrees of rank to be found in the western countries. In place of the lawless barons they created an aristocracy which served the interests of the state. From the sentry they formed a new and reliable order, and by sranting them fortune and titles attached them to the throne. The Court of the Angevin kings became the great centre for the aristocracy, but in return for distinction: granted the king required the discharge of serious dutien. The aristocracy rendered valuable services, among others, supplying the greater part of the military forces.

The ancient fortress system of the days of St. Stephen was becoming obsolete, and it no longer supplied the 


\section{MONARCHICAL REACTION IN HUNGARY.}

country's needs. The permanent duty of the gentry to serve their king and country could not make up for the decay of the true military class of the fortresses, because the privileged classes in general could not be compelled to serve abroad, and moreover, they were not accustomed to constant military discipline. In considering the fact that in England taxation constituted the most serious burden upon the people, whereas in Hungary it was military service which pressed most heavily, we found the explanation largely in the circumstance that lingland waged many aggressive wars, but was much less frequently than Hungary compelled to defend her own borders.

The history of the Angerin kings confirms this explanation. In the case of a defensive war, every one is animated equally by a sense of the common duty, while in wars of aggression, the ruler has to find special means.

As Louis engaged in aggressive wars he had to adopt the practice of the English kings. He persuaded the aristocracy which he had created to organise its military forces. He flattered the vanity of the magnates, and induced them to form companies (banderia), which they themselves should lead, beneath their own flags. Of the army thus organised the ling could dispose. He had the riglit to take it abroad if necessary. All that he had to do was to win over the magnates themselves, and he understood the art of doing that better than anyone before him.

That paragon of all the virtues of chivalry knew the weakness of the magnates, and by gratifying their ambitions made of them a strong support of the throne.

Beside the services which war made necessary, the magnates also rendered valuable services in times of peace. Louis the Great familiarised them with affairs of State, and appealed to them for their advice.

Members of their class served as Palatines, County Lieutenants, and the like. To enable them to be in a position to discharge their various duties, and especially to maintain their private companies of soldiers, I,ouis 


\section{DEVELOPMENT OF HUNGARIAN IABERTY.}

altered one paragraph of the Golden Bull, which empowered a man to dispose freely of his property, and decreed that in future if any nobleman died without leaving a direct heir, the property was to go to the nearest branch of the same family. This law was not designed to prevent the division of large fortunes, but to protect the nobility as a whole by stopping as far as possible the escheating of estates to the Crown. Under the new law it was not until the whole family had died out that the estates reverted to the king.

Another means by which the king wished to enable the privileged classes to serve him better, was a new tax called the "Kilenczed" (the ninth part). The prelates the magnates, and the gentry had to collect this tax from their dependants. If anyone neglected to do so, he was liable to the king for the amount.

We must distinguish this law from somewhat similar laws in other countries, which empowered the lords of certain donains to collect the taxes, for the law was not conferring a privilege but imposing a duty. The owners of estates who received the tax in money handed it on to the king in the form of soldiers. The taxes they gathered were not for themselves, but for the nation, and they could neither alter nor forego them.

As a result the nobles worked hand in hand with the king. This was the great merit of the Angevin kings, that they were able to organise the nation, and to use money and titles in the interest of themselves and of the country without coming into collision with the people's strong national feeling.

The reign of the Angerins left a deep and lasting impression upon the country. It was their hands which shaped the mediaeval Hungarian constitution, which in its fundamental features endured for centuries. The nobility also entered upon a new phase of its development.

Formerly the wealth of the magnates was the basis of their power, but that power had no moral foundation, for it was not correlated with duties. The Angevins 
altered all this. By means of the banderium army system important duties were assigned to the magnates, who thus acquired a moral basis for their influence.

When Louis died the outline of the future State was ready. The filling-in depended upon the way in which king and nobles worked together. During the reign of Louis the Great, there was the utmost harmony in their relations.

The future alone could show whether the like harmony would prevail if the occupant of the throne should happen to be a less exceptional man.

In England, it was during the reign of lidward 1. that the constitution was shapecl which endured throughout the Middle Ages, and from which the modern parliamentary system was gradually evolved. That constitution in its principal features resembled that created by the Angevins, and in both the power was divided between the king and the nobles. The king remained at the head of the nation; the executive power was his, but he had to give a share in the work of legislation to the privileged classes. Those classes became the predominant elements of the State. The military force at their command was greater than that of the king.

The question was whether they could remain at peace with one another. If each of them had had his sphere of activity clearly marked out for him, and had confined himself to it, they could have worked peacefully together, but this ideal state of things was hardly possible in any country. The Middle Ages were lacking in respect for law, and the various fields of activity were not well-defined. It was in defence of private rights that the reforms of the thirteenth century were initiated, but in the realm of political rights very much was still unsettled. In England it was an accepted principle that the work of legislation should be divided between the king and his Parliament. Edward I. advocated this principle. In form, however, the law remained the legal expression of the king's will, 


\section{DEVELOPMENT OF HUNGARIAN LABERTY.}

and Edward even introduced some laws without consulting Parliament.

The custom was that the king decreed with the advice of the lords and commons, but it was a question whether he was obliged to heed such advice, or, if he decided otherwise, whether his commands would be valid.

The position in Hungary was still less clear, because not even the principle that king and parliament should participate in legislation was definitely established. In his first law Louis conformed to that principle, but he frequently issued decrees without the co-operation of Parlianent, and he amended existing laws in accordance with the country's needs.

Edward 1. solemnly acknowledged the principle that taxes could only be imposed with the consent of Parliament, but it remained an open question whether the custom duties came under the head of taxation, and the king, after consulting some of his counsellors, often levied certain dues and fines, declaring that he was entitled to them without the consent of Parliament.

Louis l. imposed the tax called the "Kilenczed" (oneninth) with the consent of the nobles, but it was problematic whether this precedent was binding upon his successors. II is father had acted differently, and when taxes came to be demanded more and more frequently, the people found there was no law which declared once for all that the king could not impose taxes without the consent of the Diet.

The question of the executive power was also calculated to engender strife. Both in England and in Hungary the thirteenth century laws which placed the executive entirely under the influence of the privileged classes, had become obsolete. Edward I. and Louis the Great, soverned their realms with the aid of officials nominated by themselves. The idea still persisted, however, that the nobles had the right to control the king's policy, and to call to account the officials who governed badly. Any such interference had become 


\section{MONARCHICAL REACTION IN HUNGARY.}

unnecessary, because king and nobles were in harmony, especially in Hungary, where the king's personality had created the most perfect confidence, but collisions were to be looked for when the situation changed, for there was no law which regulated the degree of influence which the nobles were entitled to exert upon affairs of State.

All the time, king and nobles, obedient to their instincts, pressed forward in the struggle to gain increased power.

The king was the source of all rights. His power, so he thought, was of divine origin, and opposition to it was a crime. But this lofty conception of sovereignty might easily prove fatal to one, who, thinking everything lawful for him, should aim at absolutism.

Even such monarchs as have been great enough not to lose their heads on the dizzy heights of sovereignty, have often been urged to arbitrary action by the knowledge that the people needed them and their guiding hand. Only the best monarchs fully realise that the real source of their strength is respect for the country's laws.

The nobles had a share in the highest function of the ruler, legislation. But those whose word is decisive in the most important matters generally consider it their right to be consulted in smaller details as well, and think that they should themselves administer the laws they make. Legislators often try to pass the limits of their proper field of activity. Their instincts prompt them to subordinate the executive to themselves.

Both the English and the Hungarian privileged classes were urged by remembrance of power acquired in former times, to endeavour to regain what they had lost during the reign of Edward 1., or of the Angevins. Their wealth and power and princely mode of life, fed their ambition. It was inevitable that the harmony established by Edward and Louis should be destroyed sooner or later, and that the strife between king and nobles should be renewed. 


\section{DEVEIOOPMENT OI HUNGARIAN IIBERTY.}

A nation's future is the logical outcome of its past, and the greatest statesman cannot divert the current of a nation's life from the channel marked out for it by past developments. Both lingland and Hungary in the fourteenth century inherited a general situation which rendered internal strife inevitable. The past had assured to one party such advantages as were bound to play a great part in determining the issue of the struggle. It was in a sense predestined that the nobles should acquire more and more influence. The royal power, which had been maintained at a high level by Edward 1. and l,ouis I., had to struggle against so many disadvantages that its decline was inevitable. The trouble was that the permanency of the kingly power depended upon whether or not those great lings had equally eminent successors. Unfortunately they had not, so the inevitable happened. During the fourteenth and fifteenth centuries, until the time of the Tudors in England, and of Matthias in Hungary, the royal power constantly diminished.

In the eleventh century. St. Stephen and Villiam the Conqueror restricted the nation's liberty. By doing this they preserved the integrity of their realms, but their centralised system, superimposed upon a system of free institutions which were not aholished, was tempered by the spirit of ancient liberty. Then chaos again threatened, in the form of the rule of the great nobles, when all at once Edward in England and the Angerins in Hungary arrested the impending avalanche. They established an equilibrium which satisfied the requirements of the age, and they abolished those innovations which had too prematurely been made. But the kings were not able to retain this dominant position. The privileged classes acquired such rights and powers that under a mediocre king orderly government could not be long maintained.

In both countries, in spite of their politically advanced state, reverence for law was still so undeveloped, and the unequal distribution of wealth and power gave such enormous influence to a few individuals, that it was diffi- 
cult to bring order, the authority of the ruler, internal peace, and the people's freedom into harmony.

The Middle Ages were a period of chaos as regards government. Germany, France and Italy could not extricate themselves from it even for a little while. In England and in Hungary the monarchs succeeded in maintaining a uniform organisation and in breathing life into the body politic, but the reign of some weak king, or a political disaster or defeat in war, profoundly affected even those rigorous states.

In the fifteenth century constitutional life in England and in Hungary showed signs of disintegration. Both countries were threatened with anarchy. This is the explanation of the events of the fourteenth and fifteenth centuries.

In the next chapter we shall consider how the monarchs endeavoured to maintain their power in spite of adverse circumstances, how some of them succeeded in arresting the movement against them, while others precipitated a crisis by their obstinacy. 


\section{CHAPTER VIII.}

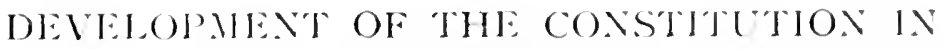 ENGLAND.}

It was a great advantage to the English monarch; during the fourteenth century that since the time of Elward 1. the right of inferitance to the Crown was recognised. The election of the monarch had ceased, and the reign of the new king began at the death of his predecessor. As against this, there were two circumstances which faroured the privileged classes of the nation. One was that the bulk of the military power was supplied by those classes, and the other the fact that Parliament had control over taxation. These two conditions placed considerable power in the hands of that portion of the nation which played a part in public affairs, for the king badly needed both men and money for his French wars.

There was no standing army in the pay of the king, and this diminished his authority very much. At a time when practically everyone was a fighter, equal to the professional soldier, no king could tyrannise over a people so strong as the English or the Hungarians.

The king's situation became no better in this respect after the Norman period. The service of the great feudal lords was not unconditional. They were not willing to serve abroad, and they considered it their duty to fight only when the king led them in person. Accordingly, they were not of much use to the king in his French wars.

Still less could he reckon upon that universal military service which was only intended for purposes of 


\section{THE CONSTITUTION IN ENGLAND.}

defence. The only way in which the monarch could render himself independent of the barons was by forming a paid army of his own, but he was not wealthy enough to maintain a force equal to that of the nobles. Hence he was obliged to encourage the nobles to maintain troops, with which they could supply him at his need, but for this convenience he had to pay a price, and that price was a part of his power. Edward III. and Henry V. were able to lead large armies to France, yet they had very few soldiers of their own. They vanquished the French king, but they had to handle their own subjects gently. Formerly, the whole nation was ready to take up arms at the call of the king, so that he was the natural head of a vast army. Now, only money could procure him soldiers, and money could only be gained with the consent of the nobles. As the frequent wars demanded a large number of soldiers, the control of the purse became all important. The privileged classes realised this, and exerted themselves to prevent the king from obtaining money without their consent. Originally the prevalent idea was that no taxes should be levied save such as were offered voluntarily. This was gradually modified to the conviction that with the exception of the Church, no one should give money for State purposes, or should impose taxes, save Parliament.

Magna Charta had been based upon the older idea. It did not empower the council to impose taxes upon the whole community. The council could only deal with the taxes paid by its own members. Public opinion still expected the king to discuss the question of contributions with the towns or associations of merchants one by one, and it would have condemned the imposition of a universal tax.

Edward I. created a central body capable of speaking for the whole nation, yet he did not abandon the right of bargaining with the different elements of the nation individually. As soon as the kings realised what power they had yielded into the hands of the higher classes they 
at once tried to revert to ancient methods of bargaining, ignoring Parliament. Import duties were imposed, and taxes demanded from towns built upon Crown property, without the sanction of law, but Parliament gained more and more control over the purse, and the monarchy found itself unable to stem the ticle. It could, however, count upon the people's loyalty. The sacredness of the king's person was 'mphasised more than ever before, and the conception of treason was introduced into the code.

The new rules of succession abolished even the form of election. The dynasty was linked by marriage to powerful elements of the nation, and it had many means of furthering individual interests and thus creating a party devoted to it.

Yet all this did not enable the Crown to wrench the control of taxation from the hands of Parliament. The ling endeavoured to raise money by virtue of his prerogatives, ignoring larliament altogether, but this step aroused rehement opposition. The military forces at the disposition of the community formed an ultima ratio against the king, and made Parliament master of the situation.

Edward II. was weak, and uttery unable to walk in the footsteps of his great father. The efforts which had been made during the reign of Henry III. to transfer the executive power to the privileged classes were renewed. The king's favourite minister was impeached and condemned. Laws were forced through to which the king was strongly opposed, yet he could not declare war, for he had no army, and he could not leave the country without the consent of the barons. There was formed from his adversaries a council without which he could not act, and he was obliged to fill the principal offices with nominees of the barons. But these reforms did not prove a success. As the barons pursued only their own interests, the bulk of the nation repudiated them and sided with the king, enabling him to overcome his enemies. Since the king 


\section{THE CONSTITUTION IN ENGLAND.}

owed this victory to the support of the people he could not use it solely for his own purposes.

By an earlier ordinance he had autocratically revoked certain laws which were humiliating to him, but now he had to accept the principle that whatever had been enacted by king and Parliament could only be altered by mutual consent.

The principles enunciated by Edward I. passed into law during the reign of his son.

Edward II. soon became involved in new difficulties in consequence of his utter weakness, and the nation turned against him and acquiesced in his deposition. Violence then reigned supreme, but it sought the sanction of Parliament for its deeds, thus furnishing evidence of the growing importance of that body. Everyone had come to regard the voice of Parliament as the expression of the nation's will, so that the triumphant party thought it expedient to have their actions confirmed by legislation. On the other hand, Parliament was still so far tractable that its resolutions were capable of being over-ruled, so that its existence never hopelessly conflicted with the interests of whatever party happened for the moment to be strongest. That is why even a violent revolution ministered to the growth of the parliamentary institution, whose very weakness and pliability proved serviceable in the stage of its development which it had then reached.

The reign of Edward 111. shows still more clearly how favourable the situation was to the more influential classes of the nation. The failure of Edward II. may easily be attributed to his personal shortcomings, but his son was one of the finest soldiers of the age. Edward III. was a born commander, and he clung tenaciously to his prerogatives. All his life he struggled against the increasing power of the nobles, but in vain, for fresh concessions were constantly extorted from him. The srowth of parliamentary influence in his reign was due, not to a successful revolution, as in the case of Edward II., but to the use of constitutional means. The violent 


\section{DEVELOPMENT OF HUNGARIAN IIBERTY.}

methods of mediaval times were then first replaced by a constitutional and peaceful trial of strength. Consequently, in spite of internal political conflicts, the nation was united, and strong enough to conquer the French.

The growing importance of Parliament established to a certain degree equilibrium between the various sections of the privileged classes. Militarism was pre-eminently favourable to the greater nobles and assured to them at leading role, while the control of taxation placed great infuence in the hands of the commoners who constituted the majority in Parliament.

It is interesting to follow the struggle between king and Parliament, for the tacties developed were typical phenomena of a constitutional régime.

The king's great aim was to gain money for his French and Scotch wars, and he tried every conceivable means of doing so without consulting Parliament. He bargained with merchants about duties, raised loans, demanded that the court and the army should be provided with food, clothing and other necessaries, and endeavoured to revive compulsory military service. Circumstances were too much for him, however; tax after tax became necessary, and Parliament gave nothing for nothing. The nation really purchased its political rights. Money was not refused, but it was granted upon certain conditions. It gradually became the custom for the nation to lay before the king its grievances and its demands before roting a new tax. The king had to listen, and senerally promised compliance, but he usually hesitated to keep his promise, seeking to evade it by turning the meaning of his words. Parliament, however, demanded a prompt answer to its requests, and usually the king had to give in.

In 1340 it was enacted that no new taxes were to be imposed without the consent of Parliament. In 1362 and in 1371, it was declared that the duty on wool was illegal because it was offered by the merchants without such con- 


\section{THE CONSTITUTION IN ENGLAND.}

sent. In 1362 a law was passed against the abuses connected with the custom of purveyance by which provision was made for the needs of the Court. A law passed in 1852 2 enacted that save by consent of Parliament no one could be compelled to render military service at his own expense.

All these laws made it increasingly difficult for the king to act independently. In return for money supplied, the king even gave a share of the executive power to the influential classes. Edward III. was compelled to retain a minister whom he desired to dismiss. Towards the end of his reign he had to abandon his councillors against his will, and to see them condemned on charges brought against them by Parliament. Even the purposes to which the money granted was to be devoted were determined for him, and the responsible officials were liable to be called to an account of their stewardship.

In military and foreign affairs Edward III. voluntarily sought the advice of the nation's representatives, submitting to them questions of peace and war, in the hope that by sharing with them the responsibility he might ensure their goodwill when money was needed.

The strength of Parliament is strikingly shown by the circumstance that the hero of Crecy was driven to use the weapons of the weak, such as petty mental reservations and the breaking of promises.

The explanation of the tragic end of Richard II. lies in the fact that he did not possess the tact of his father. Both lings clung to their prerogatives, but Richard was impatient and passionate, and tried to achieve more than Edward with less talent. His obstinacy provoked serious conflicts. On one occasion, when he was in need of money, Parliament urged him to dismiss two of his ministers. His haughty reply was that he would not dismiss even a cook at the bidding of Parliament.

The king, however, was powerless to defend his adherents, or even himself. The nobles threatened him 


\section{DEVELOPMENT OF HUNGARIAN LIBERTY.}

with deposition, propounding the theory that a king who violated the law might be remored, and Richard, yielding to force, dismissed his farourites; a committee appointed by Parliament regulated the royal household and investigated and reformed the whole government.

Still greater humiliation was in store for the king when he endeavoured to put an end to these reforms by force, for his adversaries were too strong for him and became the real masters of the state after executing the king's chief adherents. Richard's energy and courage enabled him to cast off the yole two years later, and after his success he acted for some time with moderation. $\mathrm{He}$ was content with merely dismissing those who had humiliated him, and tolerated Parliamentary control.

He was so far indulgent that when Parliament was summoned his ministers voluntarily sent in their resignations and desired Parliament to pass judgment upon their government, after which they resumed office.

The king cleverly adapted himself to the situation and thus increased his popularity to such an extent that he became conceited, and, carried away by passion, again aimed at absolutism. He knew that Parliament was so strong that his only hope was to construct it out of such materials as would be ready to surrender that power voluntarily. Such a packed assembly could alter the fundamental laws of the country. The king tried the experiment, at first with success. Parliament itself demanded the augmentation of the king's power. It voted taxes for the whole period of his reign, and surrendered its power into the hands of a committee. The king in this way became absolute. But soon the whole situation changed. The nation knew that the new laws were not really valid.

Henry Bolingbroke had the whole country with him in the view that Richard's Parliament did not represent the nation, and that the king broke the law even while observing its form. When Henry defied the king every- 


\section{THE CONSTITUTION IN ENGLAND.}

one joined him. Richard's absolutism collapsed and he was deposed.

The documents relating to the king's impeachment show that Parliament knew perfectly well what it was doing and that it realised the significance of that trial. It crowned the victory by abandoning the principle of hereditary succession and by electing another king. Parliament had disposed of the crown. That was the end of the first act in the long conflict between king and nobles.

When the Lancastrian dynasty succeeded to the throne the champion of the nobles became king. This then was the result of the long effort of the Plantagenets to establish their own superiority over Parliament. The advent of the house of Lancaster meant a new epoch in the history of freedom. The new dynasty remained faithful to its origin. It made no effort to suppress Parliament, but on the contrary, tried to solve the problems of government with its aid and in conformity with law.

The first two monarchs were successful, although Henry IV. often found himself in antagonism to the nobles. Those who had given him the crown made excessive demands upon him. A throne gained by means of a revolution rests on insecure foundations, for it seems to constitute a justification of revolution. Henry's life was not free from bitterness caused by rebellion, but his throne remained secure, and it is a fine feature of his character that as a king he remained faithful to the principles he had professed when a subject. His reign was attended by important results. In spite of the strength of Parliament he was able to lead the nation, and he founded a strong dynasty.

Henry $\mathrm{V}$. lived in much greater harmony with the nation. He was really an eminent ruler, and by his striking personality, his grandly conceived foreign policy, and his brilliant achievements on the battlefield, he won over the whole nation. He was not jealous of Parliament, for he could lead it in any direction he desired. 


\section{DEVELOPMENT OF HUNGARIAN LIBERTY.}

Parliament was in that age so firmly established, that both the meakness and the strength of the various kings proved of advantage to it. The weakness of Edward 11. and Richard II., as well as the strength of Edward III., Henry IV., and Henry V., could but increase its importance.

The capable monarchs who might have been able to injure Parliament showed their good sense by avoiding dangerous conflicts, and sought rather to gain influence by befriending the institutions which safeguarded the people's liberties, while those rulers who strove to oppose the current of events were generally so weak as not to be dangerous, and their attacks only strengthened the Parliament's position.

By the time of the Lancastrian kings Parliament had reached a period of its development when it could only be injured by itself, and when, if it used its power for the welfare of the nation it could become invincible. The question remained whether it would act thus. The mere fact that it had won the victory did not prove that it would use its victory for the benefit of the country. On the death of Henry V. a child succeeded to the throne, and when that child became a man he was utterly weak and incapable, and unfit for the task of curbing the power of the dominant classes. It remained to be seen whether Parliament, which had successfully resisted royal tyranny, would not be undone by its own exaggerated power. The event showed that the weakness of the monarchy proved fatal to the parliamentary system, as there was nothing to keep within lawful bounds the ambitions of the nobles.

In earlier times parliamentary government was based upon the reciprocal control of king and barons, and this mutual restraint left a field for the third factor, the House of Commons. While the monarchy was strong enough to hold its own neither of the two parties could afford to neglect constitutional forms and pursue an openly selfish policy. Whoever wished for success had to identify his personal aims with those of the nation. Even the most 


\section{THE CONSTITUTION IN ENGLAND.}

powerful nobles chose rather to fight with constitutional weapons than to resort to force, for if their aims were too obviously self-centred they alienated the commons and the king was sure of victory. They sought the protection of law even for their deeds of violence.

The great kings, Edward Ill.. Henry IV., and Henry V., by the wisdom of their policy, prevented internal struggles from crippling the country's capacity for action, and were strong enough to prosecute vigorously the French wars.

Rulers like Richard Il., just because they attacked the country's liberties, roused the public spirit of the people, and provoked energetic action on their behalf.

But the decay of the royal power under Henry VI. gave rise to a different state of affairs. The great nobles, relieved of the salutary pressure exerted by the monarch, felt themselves strong enough to ignore legal formalities.

Possessing all the military power, with no one able to call them to account, they openly pursued their individual interests, heedless of their duties to the rest of the nation. Even during the reign of Henry IV., the king had to contend with the personal ambitions of dissatisfied nobles, but their discontent did no harm under a strong king, but rather served to strengthen the position of Parliament. During the minority of Henry VI., however, the whole of the executive power came into the hands of the nobles, and their mutual rivalries worked the greatest mischief.

It is not surprising that the long struggle with France came to so unfortunate an ending, when it is remembered that the Duke of Bedford, who was charged with the conduct of the war, sought to maintain the alliance with Burgundy, while the Regent at home provoked the hostility of Burgundy, in pursuit of his private interests.

Henry VI., on coming of age, tried to pursue a peaceful policy, but failed. His defeat, which was largely due to the excessive power of the nobles, increased the danger of the situation by undermining the authority of 


\section{DEVELOPMENT OF HUNGARIAN LIBERTY.}

the government, and heightening the general disaffection. When the war with lirance came to an end, the forces which had been occupied abroad returned to bring new fuel to the fire of internal strife. Long-continued civil war followed as a natural result. The nobles carried on warfare with one another, but now it was no longer merely for some private interest or share of political influence, as in former times; the prize they fought for was nothing less than the royal crown. The gentry followed the lead of the nobility, splitting into rival parties. Parliament sank into impotence, and became a puppet in the hands of one or other of the parties. The victorious party controlled the elections in its own interests, and thus obtained command over Parliament. Law remained in abeyance, and anarchy prevailed everywhere. The revolution threatened to sweep away the Lancastrian dynasty. The most powerful nobleman, Richard Duke of York, claimed the throne, and after his death his son, Edward IV., achieved the aim which had been his father's. It is characteristic of the situation that it was only a few of the barons who proclaimed Edward king, and Parliament merely endorsed their action.

The victory of the House of York was of first-rate importance. It was due to the felt necessity of a strong government, and signified that the nation had had enough of the exaggerated power of the privileged classes. Until the advent of the Tudors Parliament had been the dominant factor, and it was through its instrumentality that the strongest elements of the nation sought to control the country's affairs. Circumstances were favourable to the privileged classes, and their strength increased in spite of the opposition of the Plantagenets.

While the monarch had control of the executive, the parliamentary system worked well, but ultimately Parliament grew more powerful than was desirable, and in 1399 entirely overthrew the monarch. This provoked a reaction, for the very unity of the nation was seen to be in danger, and the need of a strong government made 


\section{THE CONSTITUTION IN ENGLAND.}

itself felt everywhere. That great bulwark of national unity, the monarchy, found a powerful support in the people's instinctive desire for unity, and commenced once more to flourish.

In history it often seems as though long ages of effort merely lead back to the starting point of the process, but this is only a delusive appearance. Even though there is some apparent falling back, yet the nation is nevertheless advancing. In England, although the parliamentary system broke down, yet the cause of freedom did not stand where it had stood before the long struggle. Something had been achieved which could not be destroyed, and which furnished a starting point for future developments. The parliamentary system had been firmly founded, and had received a definite shape. Its two houses had been created, with their respective spheres of activity clearly defined, and the work of legislation properly divided between them.

The House of Commons had the right of voting the taxes, while the upper house discharged judicial functions and took the lead in any delicate political matters.

Though Parliament had for a time diminished in influence, it had dereloped such an organisation that as soon as a new spirit awoke within it, it would again be capable of effective action. The successes and prerogatives which Parliament had gained were precedents of immense value. Several events which had seemed to be the mere chance results of a particular situation, became in after years the germs of such conceptions of constitutional right as have formed the very essence of modern parliamentarism. It is the course of events in the thirteenth to the fifteenth centuries which links the days of Anglo-Saxon liberty with modern times. The strength of the traditions of freedom lay in their continuity. 


\section{CHAPTER IX.}

THE DEVELOPMENT OF THE HUNGARIAN CONSTITUTION FROM THE TIME OF THE ANGEVINS TO THE ACCESSION OF MATTHIAS.

\section{PART I.}

TO THE DEATH OF SIGISMUND (1437).

It was after the death of Louis the Great (1382) that Hungary entered upon a period characterised by the excessive power of the privileged classes of the nation. The movement towards liberty, which began in the thirteenth century, was only temporarily arrested by the Angevins, and was inevitably renewed. The reign of Louis the Great was of an exceptional character, merely because he himself was an exceptional personality. The course of events in England was bound to repeat itself in Hungary.

The energy of the nobles and the widespread love of liberty inevitably led to the same results in Hungary as in England. History is governed by fixed laws.

The varied personalities which play their parts, and the infinite diversity of events, affect history in such a way as to make every page of it seem different and every detail full of individuality, so that it is of more absorbing interest than the boldest creation of fancy, yet all these individual factors taken together are unable to make a nation deviate from the path marked out for it by its nature and environment, or nullify the laws which make history a science and enable us to interpret the past and forecast the future. 


\section{THE HUNGARIAN CONSTITUTION.}

The constitutional history of Hungary during the fourteenth and fifteenth centuries bears the impress of many kinds of men and events. Many things happened which seem the outcome of chance, owing to human inability to trace their causes, and it is certain that the history of Hungary during that period was different from that of the other countries of Europe. Yet in spite of these manifest differences, Hungarian history was in its main outlines very similar to that of England.

In both countries the power of the monarch was diminishing, while that of the nobles increased. The natural tendency of the age, which in France and Germany reduced the monarchy to impotence, made itself felt in Hungary also. The only difference was that there the monarchy, pursuing aims of the first importance, and supported by the strong national sentiment and the national institutions, was able in some degree to control the tendency, so that it never came into fatal collision with the fundamental conditions of the nation's well-being. Decentralisation was reached, not through disintegration, but through the extension of popular freedom in Hungary as in England. The champions of liberty, made strong by past conflicts, were able to prevent the weakness of the monarch from leading to the dismembering of the nation. England and Hungary, unlike other European nations, displayed in their development, even during that epoch, the characteristics due to national unity. Yet though both countries were able to avoid disintegration, they could not prevent the nobles from attaining to a degree of power that was mischievous and productive of chaos, and which ultimately provoked a reaction in favour of the monarchy.

This series of events was inevitable. Only under exceptionally able kings was it likely that the nobility would not abuse its power and such men are given to a nation but rarely.

As in England, the situation in Hungary was favourable to the nobility, which had control over the greater 


\section{DEVELOPMENT OF HUNGARIAN LIBERTY.}

part of the military forces. Even during the time of the Arpád kings the strength of an armed nation was the chief obstacle in the way of the monarch's absolutism, and since then this force had been organised in such a way as to make it readily arailable against the king.

In the banderia of the nobles the monarch found the readiest means of obtaining troops. Even if he had to pay for them they cost him much less than the maintenance of a regular army would have done. The security of the persons and property of the nobles renclered it necessary that they should garrison their fortresses, and when they lent their troops to the king, they were not only performing a patriotic duty, but also lining their pockets with the money received. The military system, therefore, was beneficial both to the king and to the nobility.

The laws relating to military matters in England and Hungary were different, yet the military organisation took the same form in both countries. Though universal service in defence of the country remained the law in Hungary, experience had shown that something more was necessary, and companies of soldiers in the pay of the nobles were formed all over the country and constituted the bulk of the military force of the state. This situation led to the same results as in England. The nobles took the leading part, and together with military strength, political power also came into their hands. The greater part of the military forces owned allegiance, not to the king, but to the great nobles, whose consciousness of their own power so stirred their ambition that they were ready to stand against the king.

Thus the monarchy, whose authority depended upon borrowed power, got into an entirely false position.

The king was surrounded by turbulent elements, to control which demanded exceptional ability and strength of character, and also favourable circumstances. In former times, before private persons had gained so much military power, a revolution was impossible unless some weighty evil pressed upon the whole community, or at 


\section{THE HUNGARIAN CONSTITUTION.}

least upon the inhabitants of a large district, while now, in virtue of the altered condition of affairs, a single nobleman might rise against the monarch. Consequently the king needed to walk warily in order to maintain his authority. Everything depended upon whether he could remain at peace with the nobles. If he was on friendly terms with the most powerful among then he might break the law with impunity, but if he roused their animosity his position became untenable. Absolutism was impossible, because the nobility would never have supported him in any efforts to achieve it. The country's freedom was assured by the circumstance that the bulk of the military power was in the hands of the nobles, who cherished traditions of independence, and who were eager to maintain the constitutional limitations of the royal authority for personal reasons.

It is true that in Hungary, in consequence of the danger of Turkish invasion, universal compulsory military service was instituted, but even this did not make the king predominant.

It altered to some extent the distribution of power and improved the king's position a little, because it increased the military power of the gentry, and the ling could use this to counteract the influence of the magnates.

In England, as we have seen, the sword was not the only weapon which the nobility could use against the king.

Instead of sanguinary revolution, the nobles often employed constitutional means. In Hungary, however, this was not the case. The English king could not conduct his war with France without the taxes voted from time to time, and he was therefore obliged to conciliate Parliament.

In Hungary the situation was different. The taxes constituted but a small part of the entire budget of the country, and if the king needed exceptional supplies of money he pawned an estate or two, or obtained a loan. He had a large permanent income from his estates and 
from various tolls and duties. The burgesses of the fortified towns also contributed regularly to the royal exchequer. It was not the Diet, therefore, which supplied the king with funds, and so the voting of taxes was not a powerful weapon in the hands of the nation, as was the case in England. Only towards the end of the period we are considering did the control of taxation begin to acquire importance.

The nobles were protected by their wealth. Had the king's income been great enough to allow of his maintaining a powerful army he would have become a danger to the community in consequence of his independence of the Diet. Fortunately his income was not sufficient for that, so his power remained limited by the superior military strength of the nobles.

One other circumstance compelled the monarchs to respect the will of the nation, and that was the short duration of the various dynasties which ruled over Hungary. In England inheritance by descent had remained the rule since the time of Edward I., while in Hungary the right of free election of the monarch had been coming more to the fore during the same period. Consequently the English kings fought more strenuously for their prerogatives and withstood the nobles more stubbornly than the Hungarian monarchs, who pursued a more liberal and conciliatory policy.

After these general remarks, let us consider the way in which the influence of the nobility spread in Hungary.

The royal power which the Angevins had done so much to augment, soon crumbled to pieces. Just as the strong rule of Edward I. was followed by the feeble hand of Edward II., so the reign of Queen Mary (1382-1395) in Hungary was in marked contrast with that of her predecessors, and showed of how exceptional a character was the influence exerted by them and that the nobles were masters of the situation.

The motive of the revolt against Queen Mary is not clear. We do not know whether it was the unlawful 


\section{THE HUNGARIAN CONSTITUTION.}

character of her rule, or her weakness as a woman, or personal wrongs suffered by a few, but the fact remains that some of the great nobles turned against her. It was in vain that she confirmed the Golden Bull, and summoned Parliament in order that the growing disturbance might be stopped. The malcontents invited Charles of Naples to occupy the throne.

The queen herself owned that "a weak woman cannot govern a proud and turbulent nation." She was right, for even the strongest kings found it a task almost beyond their powers. Only to a commanding personality would the nobles, strong in their possession of estates and troops and fortresses, yield obedience. Queen Mary was deposed, and Charles was proclaimed king by the Diet, in the very presence of the queen (1385). In a few weeks, however, the nobles abandoned Charles, who was murdered by one of the queen's adherents, and Mary regained the throne. The "Naples" faction was confined to the southern portion of the country, the territory of the Horvathy family, and it happened by chance that the queen fell in to the hands of that faction, and was imprisoned by them. But the bulk of the magnates and the gentry were devoted to law and order.

A vigorous people, possessing initiative and independence, may indeed be dangerous to the monarch, but if such a nation is loyal, it is a much more reliable support than a servile crowd. Strength which can be destructive is also useful for defence, as happened in this case.

The people caused the Diet to be convened. They realised that much of their trouble had resulted from their following bad advice, and they declared that thenceforth members of the council must serve, not only the monarch's interest and their own, but also that of the country and the sacred crown. Anyone acting otherwise was to be excluded from the council. To conciliate the gentry it was decided that representatives of their class should sit in the council, as well as the barons and ecclesiastical dignitaries. The people seem to have found the revolu- 


\section{DEVELOPMENT OF HUNGARIAN LIBERTY.}

tion sufficiently justifiable to render it advisable to proclaim a general amnesty. In the spirit of the Golden Bull it was declared that if the queen deviated from the terms of that charter no one need support her, but on the contrary, she should be openly opposed.

These were interesting decisions. The nation maintained the monarchy, but laid down rules for its guidance. It defended the throne, but limited its power. The same policy was pursued on the election to the throne of Sigismund, the husband of the still imprisoned Mary. The object of raising Sigismund to the throne was the restoration of order, but the dominant classes did not forget their own interests and prerogatives.

Sigismund (1387-1437), before his election, entered into a contract with the leaders of his party, representing probably the most powerful families of the country, in which he promised to defend the nation's liberty, not to take revenge on anyone for past events, and to grant special protection to those with whom the contract was made; further, that no foreigners should be appointed to offices of state, and that no member of the party should be excluded from this compact without the consent of the rest. If the king in any way violated the agreement, the leaders were entitled to refuse him obedience and to oppose him openly.

This contract is a mirror of the situation, and reveals the spirit of the times. National liberty was based upon the right of armed resistance. The enormous power of the magnates is indicated by the fact that they contracted with the king on equal terms. The same fact shows that the king was beginning to lose the character of a sovereign, and his position was becoming more like that of a chosen leader of a coalition of parties than of a king "by the Grace of God." This was a great decline from the commanding position of Louis the Great. The turbulent disposition and ambition of the magnates, curbed for a time by Louis' personality, cast off the restraint of his feeble successor. The magnates were entirely the masters 


\section{THE HUNGARIAN CONSTITUTION.}

of the situation. First they dethroned the queen, then they replaced her and defended her against a rival. They would not subordinate themselves to their monarch, but neither would they allow one part of the country to compe! them to accept a new ruler. They were so conscious of their power that they elected a ling to rule conjointly with the queen, acting in this matter in the queen's interest, but without her knowledge. Although Sigismund had come to the throne under somewhat humiliating circumstances, he was not prepared to play a spiritless part. The notion of the divine right of the king was then becoming general, and Sigismund, though perhaps not so firmly resolved as Richard II. upon the restoration of the royal authority, aimed at the retention in his own hands of the power acquired by the aid of the magnates.

He broke his promise to make no aliens state officials, surrounded himself with foreigners, and would have liked to see the country entirely governed by them. Among. the many violations of his pledged word this was resented the most by the magnates, for it hurt both their national pride and their individual interests. The king gave deep offence in other ways.

Although he had no claim to the throne, and owed his crown to election, he decided about the succession in an autocratic manner, and while the magnates who had procured his election were all upholders of the legality of armed resistance, he had some of the resisters beheaded, thus making the nobility anxious for its own safety. Furthermore, the king squandered his revenues, and once openly manifested his absolutist tendencies by publicly declaring invalid the laws which he had passed with the concurrence of the nobility. Events of such a character inevitably filled the reign of Sigismund with unrest. The discontented nobles gathered together in the south, which became a hotbed of revolution, and the king was soon driven into the hands of the nobles of his party. As a pretender had arisen, Sigismund found he could not keep his throne without the aid of those who had raised him 


\section{DEVELOPMENT OF HUNGARIAN LIBERTY.}

to it. The Hungarian nobles were naturally unwilling to shed their blood for a ruler who damaged their interests and threatened their liberty. They pursued the same policy which had led them to raise Sigismund to the throne. They had no desire to accept the king of Naples, but they were determined that Sigismund should respect his promises. They defended the king in many battles against the revolted nobles, but when they saw that his rule did not protect their interests, they were quite prepared to turn their arms against him. His adherents would not allow the revolutionary party in the south to deprive him of his throne, but when they received cause for dissatisfaction they undertook the task themselves.

Sigismund, probably in order to create a counterpoise to the power of the magnates, invited representatives of the towns for the first time to the Diet, but even this step did not help him, as the influence of the burgesses was not very great. The king may have thought that with the help of the burgesses, who were mostly foreigners, he could stay the action of the magnates against his foreign favourites, but if this was his plan it was destined to fail. The Diet was still controlled by the magnates, and their policy was directed against the Neapolitan party and to the redress of old grievances.

A law was passed to the effect that no foreigner should hold either office or estates. Within three months every foreign courtier, with a few exceptions, was to leave the country. Further, the Golden Bull was again confirmed.

The king refused to execute the law. In virtue of his royal prerogatives he proclaimed the decisions of the Diet respecting property invalid. The foreign courtiers did not leave the country, but, on the contrary, the king made grants of land to his favourites. At last the growing dissatisfaction broke out into open rebellion. Those who had fought for Sigismund, disgusted by his ingratitude, took up arms against him, and resolved upon his deposition. When they came into the presence of the 


\section{THE HUNGARIAN CONSTITUTION.}

king, he received them with the words: "I am your ling, and you owe me obedience," but his words made no impression. Simon Széchenyi replied: "We have come to expel the foreigners. If you consent to this you may remain our king, but if not, you are our prisoner and not our ruler." And so it happened, for Sigismund was thrown into prison.

The influence of the magnates is shown by the unanimous support they received from the country. Every municipality obeyed the new government.

It has already been mentioned that Sigismund's policy resembled that of $R$ ichard II. Two years after Richard's reign was terminated by a revolution (1399). Sigismund met with a similar fate. The arrogant behaviour of the ruler led to the failure of the monarchy in both countries. The magnates, possessing military forces, and backed by public opinion, proved stronger than the king.

Richard's failure was final because he riolated the constitution more completely than Sigismund, and was therefore abandoned by all his subjects; moreover, in England there was a suitable successor. Fortunately for Sigismund, however, some powerful nobles remained his adherents, and there was no acceptable prince to take his place.

The victory of a pretender to the throne, who has once been resisted by the nation, is fraught with danger, especially to the more prominent opponents.

The new king may seek to take revenge upon them, and the new men who reckon on the king's gratitude because they have fought and suffered for him, may gain the upper hand. These considerations weighed against the claims of the king of Naples. At the same time, three other pretenders to the throne had arisen, so that the country was running the risk of grave internal dissensions. The magnates saw that the only way to avoid this disaster was by restoring Sigismund to the throne. They 


\section{DEVELOPMENT OF HUNGARIAN LIBERTY.}

had never aimed at his final deposition, and as the king seemed to have learnt wisdom from past experience it appeared fitting to reinstate him.

A compromise was effected through the instrumentality of Garai and a few other faithful members of the royal party. The foreigners left the towns, a general amnesty was proclaimed, and Sigismund occupied his throne again, this time entirely by the favour of the magnates. All depended now upon the course of action which the king would take, and unfortunately he showed that he had not learnt his lesson well enough. He did not thoroughly adapt himself to circumstances, but he took one prudent step, and that was to win over some of the magnates to his side.

He cared as little as ever for the country's laws, but he saw that he could not retain his position without the support of the nation's leading men. Formerly he had chosen his advisers from among foreigners, but now Garai became his principal minister. His gratitude was expressed publicly in a letter wherein he acknowledged that he owed to Garai his escape from exile or death, and his restoration to the throne. This is much for a king to say, for it involves the risk of becoming dependent.

His imprisonment over, Sigismund betrothed Barbara Cillei, Garai's sister-in-law, although he had been engaged to a foreign princess, as it was more important for him to stand on friendly terms with the magnates of Hungary than to fulfil an obligation to a foreign house. Experience had taught him that foreigners would not defend his throne, and that the only support he could rely upon was that of his own people.

Still, as already mentioned, the king had not learnt enough. Having won the goodwill of the more powerful nobles by furthering their individual interests, he imagined himself strong enough to contravene the country's laws. He promised the succession to the Austrian duke, and mortgaged national property to foreigners. This action of the king, together with the 


\section{THE HUNGARIAN CONSTITUTION.}

efforts of the Neapolitan party, again endangered the throne. The advent of the pretender from Naples was the signal for a general insurrection, a considerable number of the magnates and the gentry giving the claimant their support. But this heavy storm passed over the head of the king without injuring him.

It was probably favourable to Sigismund that the cause of the Neapolitan was espoused by the Pope, whose interference hurt the nation's pride. The slowness of Ladislas also contributed to the failure of the attempt, but the principal cause of Sigismund's success was the loyalty, and the military strength, of Garai, Cillei, and Perényi. The danger passed away, but it left traces behind it. The king had learned at last that he must govern in a manner consistent with the actual distribution of power. He grasped the fact that he could never use the strength derived from the military force in the hands of Garai and his other adherents, in order to establish a system of absolutism. Any efforts in this direction could lead to no result except his own deposition. The change in the king's attitude was probably due in part to considerations of this character, but partly also to the fact that events in other parts of Europe occupied his time and energy, so that he had none left for domestic disputes. A new epoch now began in his life. Until the year 1404 he had stood in direct opposition to the magnates, and had tried, in vain, to rule as an absolute monarch.

Luckily for him his efforts did not lead to the same end as fell to the lot of the Plantagenets. Sigismund escaped final failure and struck out a new path. What in England had necessitated a new dynasty was accomplished by the king himself. He proclaimed a general amnesty, and set to work to restore harmony. The Dragon Order, which he founded, was an outward sign of the relations existing between king and magnates, linked as they were by common knightly duties and common aims. Sigismund conferred this Order even upon 
Széchenyi, although he had attacked the king's person.

The enormous influence of the magnates was personified in Garai. As Palatine and brother-in-law to the king, and as a statesman who had served his soverign with perfect loyalty, he enjoyed an authority but little less than that of the monarch. During the thirty years that he remained Palatine he possessed a legislative and administrative power such as no Hungarian subject before him had known. He represented a type entirely different from that of the most powerful nobleman of the Angevin period, Count Matthew Csák. Csák's power was due, not to his occupancy of important public posts, but to his absolute possession of a portion of the country. That type was a constant danger to the community, while the Garai type was its defence. Csák was a destructive, Garai a constructive, influence. When the king was absent from the country, Garai acted for years as his substitute, and this nobleman was the king's adviser, not only in Hungarian matters, but also on great European questions.

Yet Garai never tried to act as an autocrat; he was merely primus inter pares. He settled affairs of state with the aid of the leading magnates. The king acted always with their concurrence. When he desired to punish his unfaithful wife he submitted his judgment to the consideration of the magnates. When he mortgaged the towns in the district of Szepes he did it with their approval. In the king's absence they were entitled to commence war. The royal council had the right to gather war taxes and to mobilise the necessary troops. Thus the magnates had achieved the aim they had struggled so long to attain, and had become the dominant power in the land. Sigismund was but a figurehead.

This was not the result of any usurpation, but followed naturally from the general situation, as is shown by the fact that not only the king, but the nation, as well, accepted the result with resignation. Internal wars became 


\section{THE HUNGARIAN CONSTITUTION.}

less frequent, and the country struck out a path of peaceful development.

Some historians see in the great nobles only tyrannical oligarchs, and regard those periods only as satisfactory during which the gentry have played the leading part.

The gentry were the democratic element in the past, and therefore modern democracy cannot see freedom in any age when that class did not direct the affairs of a country. But this is a wrong attitude. Whenever one class is predominant and uses its power selfishly, the government is the worst possible. The power of an oligarchy or of an ignorant democracy led by demagogues, is more dangerous in its extremes than an absolute monarchy. But a predominant nobility is not necessarily an oligarchy, just as a democracy need not be a demagogue-led mob, nor kingly power absolutism. To the question which class should predominate the answer often is, the largest class, the democratical element. 'This, however, is a mistake. It is not numbers which should tell, but moral weight.

A state can only be strong if those who are its political leaders are also able to give guidance in everyday matters of conduct also, and when the rest are ready to follow because they are accustomed to their leadership in moral and material concerns. The leading part can be played now by this class, now by that. It is in harmony with the laws of historical development that the predominant class should always increase in numbers.

Ultimately, the majority may deserve the leadership, but we have not reached that yet. When once numerical and material predominance and intellectual pre-eminence belong to one and the same class, then the supreme power may rightly be confided to the majority, but until that condition is fulfilled, the rule of the majority would be opposed to the interests of civilisation. Culture and wealth cannot yield to poverty and lack of culture, merely because the latter have numbers on their side. 


\section{DEVELOPMENT OF HUNGARIAN LIBERTY.}

Democracy is the highest ideal because that country would possess the healthiest organism in which every citizen had the ability to direct the policy of his nation.

IVe may therefore regard as progress every step which leads to a widening of the circle of those exercising control, but only at the right time and when those who attain to power know how to use it. For this reason the rise of the burgesses to power was distinctly progress, while the absolute rule of the masses to-day would be a catastrophe. For the same reasons it would have been a mistake to place the power in the hands of the middle classes in an age when the natural predominance still belonged to the aristocracy.

To-day the community willingly accepts the leadership of the middle classes. The nobility has been put down from its privileged position, and yet, where it has not been exhausted by the ineritable struggle, and has kept in touch with the nation, it is able to play a fine part by reason of its great traditions and the circumstance that its ambitions lie in the direction of political life, and also by means of its wealth which renders possible the fulfilment of its political duties.

The middle classes have not always occupied the position in which we find them to-day. There were times when the nobility had the predominance as justifiably as the middle classes hold it now, and the fourteenth and fifteenth centuries were such a period in Hungary.

During the time of the earlier Xrpád kings, differences in wealth and authority among the members of the nation were too small to be of consequence. The higher nobility began to arise in the twelfth century, and in the thirteenth century this growth of a new class led to conflicts, for the middle classes would not tamely submit to its ascendency. The Angevin period was a turning point in the history of the Hungarian nobility. It was under the Angevins that the magnates were disciplined and shaped into a body capable of serving the state. They then acquired an influence which their fortresses and 


\section{THE HUNGARIAN CONSTITUTION.}

wealth could never give them, for while they had only aimed at increasing their estates and ruling them like independent princes, public opinion was against them, but when they fought for the nation's rights and merely sought to gain for themselve's the position to which their wealth and culture entitled them, they at once became the nation's leaders.

The magnates had natural allies in the gentry, for the great nobles did not constitute a distinct easte, but were linked by the most intimate ties with the gentry.

Titles never became common even among the magnates. Many of the greatest families had no titular mark to indicate their standing; their family names, well-known to the nation, were their sole and sufficient distinction.

They were not marked out from the rest of the privileged elasses for all time by the possession of a hereditary title, and accordingly, if a magnate became poor there was nothing to distinguish him from the gentry. On the other hand, if a family belonging to the gentry grew wealthy they were at unce equal to the magnates. Some of the Palatine Garai's relatives belonged to ordinary gentry families. There did not exist all those differences of rank which were to be found in western European countries, where inter-marriage between the different classes was made very difficult. At one step a member of the Hungarian gentry might become a magnate or banneret, and again, the greatest families might become simple gentry. As the laws of inheritance did not prevent the division of estates, great families might easily decline in wealth, but the great traditions were cherished by their descendants and kept alive the aristocratic spirit within them. It is true that in the fourteenth century a Csák might be a simple gentleman, but in his own eyes he was not less than a Perényi or Rozgonyi.

This relation between the magnates and the gentry 
had many adrantages. It kept the two classes in close touch with one another. Frequently even the most powerful noble families were unable to retain their exalted position long enough to forget their origin, and to allow of the derelopment of that haughtiness which often separates the aristocracy from other classes and makes it unfit to lead them. Nor did men learn to measure a man's worth by the number of his ancestors.

It was in the reign of Sigismund that the career of Hunyadi commenced. John Hunyadi sprang from a humble family, yet he became one of Hungary's bannerets, and the governor of the country, while his son ascended the throne. Such wonderful success could only have been made possible by very great unity among the privileged classes and it in turn served to strengthen the sentiment of unity.

It was only natural that at that period the magnates should play a leading part. They had wealth and military power, and possessed the nation's confidence. From their youth they had been trained for military command and in the management of large estates, while at court they came into touch with European affairs and gained political insight. When they were unselfish enough to serve the common interests of the country they were bound to carry the nation with them. And at that time the magnates did not adopt any petty policy. They formed no separate party to further their own interests, and the lines of cleavage between parties did not correspond with class distinctions. Every party had magnates for its leaders, but it also included members of the gentry and of the burgess class. During the troubled times of Queen Mary and King Sigismund there were opposing parties, but the supremacy of the magnates was not endangered whichever party won: whether it was the family of Horváthi or Garai, Laczkfi or Kanizsai, they still remained the pivot of the nation's life. According to the turn of events now this faction or district gained the 


\section{THE HUNGARIAN CONSTITUTION.}

upper hand, now that, but while dynasties changed, the leading element of the community remained the same class.

The magnates found no necessity for establishing their position by means of laws. Agitation for legal reforms generally occurs only when the distribution of political privileges is inconsistent with the actual distribution of power. This had been the state of affairs during the thirteenth century, and was again to be the case under the Jagello kings.

During those periods, while theoretically the king was predominant by virtue of his prerogatives, the magnates acquired such power as compelled king and gentry to oppose them. Reforms were urgently demanded, and as it was chiefly through the Diet that the gentry obtained influence, their principal aim was to increase its power. But at the period with which this chapter deals, the law conferred the highest political privileges and powers upon the class whose social and intellectual leadership was accepted by the whole nation, hence reform in the direction of depriving one class of its privileges in order to confer them upon another was unnecessary. The king himself accepted the verdict of facts. His rights were exercised for him by the magnates, and that is why the great nobles did not endeavour to lessen those rights, and why the period was so barren of legislative achievements.

This conservatism did no harm to the cause of freedom. During the middle ages the happiest form of government resulted when the king remained the head of the executive, and the magnates did more good by maintaining this state of affairs than by struggling to acquire new rights and to obtain sanction in form of law for the power they actually possessed. Although the king was head of the administration, there were in his council and the chief offices under the state men whose independence of character and whose military forces made them a bulwark of the constitution, and obliged the king to listen 


\section{DEVELOPMENT OF HUNGARIAN LIBERTY.}

to them with respect. Garai, and men of his type, were faithful to the king, but they were not his tools. Garai, when Palatine, said to a Venetian envoy that even if Sigismund died, Venice must not reckon upon the nation's changing its policy, as it would tolerate no other, and any new king would have to tread the same path. This is one of those utterances which speak rolumes. When the most devoted adherent of the king could publicly declare to the representative of a foreign monarch that Hungary's policy depended not upon her king, but upon her people, whatever else might be in danger the cause of freedom might be regarded as safe. Bishop Rozgonyi on one occasion openly declared his intention of taking up arms against the monarch, a threat which he carried out.

Ujlaki, another powerful noble, when he went to Vienna, would not dismount from his horse even in the presence of the Emperor, and Pope Aeneas Sylvius (Pius II.) complained that even members of the gentry refused to bow the knee to him.

It was to be feared that men who adopted such an attitude as this towards their rulers, would prove tyrants to those beneath them, yet it was not so.

The great nobles of the time of Sigismund were enlightened enough to see what demeanour towards their subordinates their interests demanded, and they pursued a comparatively liberal policy. They made no attempt to deprive the gentry of any of their rights.

Parliament, which had rarely been summoned when the monarch was all-powerful, sat frequently during this period. The magnates did not seck to acquire fresh privileges, and legislation was carried on in Parliament, where the gentry sat side by side with the great nobles. The nation's liberty, which kings had been unable to destroy, was not in danger from the magnates either.

The laws then passed bear witness to the harmony which prevailed in the country. No section of the nation 


\section{THE HUNGARIAN CONSTITUTION.}

was hampered in its activity or fettered in any way, and no laws'sought to establish the supremacy of any one class. No obstacles were put in the way of the nation's free development, nor were any barriers raised which would have to be violently broken down at a later period.

The magnates voluntarily took upon themselves almost the whole task of the country's defence, the troops to be provided by each magnate and church dignitary being proportionate to his rank, and to the number of his dependents. It was only if the king and they together should prove inadequate to the task, that the burden of military service was to be allowed to fall upon the gentry and lower orders of the community. The more wealthy magnates, over and above their assessed quota, raised banderia from men who, while perfectly free, were induced by their poverty to serve. The wealthy classes of their own free will took upon themselves the double expense of equipping troops, and also of taking part in the incessant wars. They purchased their power with money and with their blood.

The laws then passed relating to the defence of the realm had a very great influence upon the developments of later times.

It has always been a matter of profound constitutional importance which element of the nation controlled its military forces and discharged the duty of national defence. The new laws which organised defence on the lines laid down by the Ingerin kings, and confirmed the power of the magnates, were therefore very significant.

But while the military organisation strengthened the hands of the magnates, it also added importance to the gentry, for they, too, were organised for purposes of defence. By means of the county banderia the old idea of the common duty of defending the country was revived, and political weight was given to the classes providing them.

In England, during the same period, the militia had 


\section{DEVELOPMENT OF HUNGARIAN LIBERTY.}

lost all practical value, and the only well organised military force was the army of the nobles.

This difference between the two countries led to important consequences.

The military organisation established by Sigismund unfortunately was not able to meet the country's increasing needs. Universal military service was only possible if a system of rigid discipline could have been maintained throughout the whole country, but this was rendered almost impossible for any length of time by the general situation. Yet even this practical defect in the execution of the law does not lessen the merit of those who established the military organisation of the country upon such an excellent foundation, and at the cost of so much self-sacrifice.

Administration also received attention at the hands of Sigismund and the magnates. To the duty of military defence was added that of service in times of peace.

A law was passed making it obligatory upon the magnates, under penalty, to undertake public office.

No stronger proof of the political sagacity and highmindedness of the great nobles, can be offered, than this voluntary taking up of the burden of administration at a time when there was no king strong enough to compel them, and they were absolutely free to choose.

We cannot but pay a tribute of admiration to that age. The magnates of Sigismund's day were in harmony with the nation, and wielded their power wisely. 


\title{
PERIOD OF DISINTEGRATION.
}

\section{CHAPTER $\mathrm{X}$.}

\section{THE DEVELOPMENT OF THE HUNGARIAN} CONSTITUTION FROII THE TIME OF THE ANGEVINS TO THE ACCESSION OF MATTHIAS.

\author{
PART II. \\ PERIOD OF DISINTEGRATION. \\ FROM THE ACCESSION OF ALBERT TO THE \\ DEATH OF LADISLAS V. (1457).
}

During the short reign of the Habsburg King Albert (1437-1439) there were few important events. Discontent grew, but did not reach a crisis. The office of Palatine was filled by election, a circumstance disadvantageous to the monarch, and one which to some extent destroyed the centralised character of the administration. This was the first sign of approaching disintegration.

On the death of Albert a difficult time for the dominant classes followed, for the sentiments of the dynasty came into conflict with the interests of the nation.

King Albert left a widow, who had previously been crowned queen of Hungary. Upon her husband's death Queen Elizabeth's independent right to the crown revived, for a law of 1439 had declared that the crown belonged by right of birth not to the king, but to the queen.

The nobles did not question her right, but as a woman ruler might not prove strong enough, they were desirous of finding for her a consort to share her throne, as Sigismund had shared Queen Mary's, and as King Albert had shared Elizabeth's until his death. 


\section{DEVELOPMENT OF HUNGARIAN LIBERTY.}

Queen Elizabeth had never wielded the royal power, nor had she been crowned with St. Stephen's crown, as Queen Mary, her mother, had been. As the reign of Albert had been quite consistent with the rights of the queen, no offence against her prerogatives was involved in the elevation of a second husband to the rank of kingconsort. Such a solution of the difficulty would undoubtedly have been best for the country, and the national council accordingly decided to elect Wladislav, prince of Poland. Elizabeth dared not oppose the will of the council, and her consent gave a lawful character to their proceedings. But while the negotiations with the Polish prince were still pending, Queen Elizabeth gave birth to Ladislas, the posthumous son of King Albert, and the Habsburg family deemed the child to be as indisputably king as any son to be his father's heir. 'The nobles, however, took a different view. 'They maintained that the crown of St. Stephen was not in any sense private property, but was the nation's most sacred possession, and could not be claimed by anyone without the nation's consent.

These two ideas were bound to come into collision as soon as Elizabeth, instead of insisting upon her own right, which everyone would have acknowledged, advocated that of her son, and instead of requesting the nobles to elect him, demanded to have him crowned. Her uncompromising attitude on the question of succession led the nation to cling more tenaciously than ever to the right of free election, and to choose rather to set aside the dynasty than to admit its claims.

One party to this conflict saw in the Hungarian crown a hereditary possession. The other regarded it as the free gift of the nation to the elected monarch.

Neither party was entirely in the right. The Hungarian crown could not pass by inheritance as it does to-day, but on the other hand, the right of election was never so unrestricted as it became in Poland. According to the constitution settled at Etelköz (about 889 A.D., 


\section{PERIOD OF DISINTEGRATION.}

when the Hungarians first settled in their present home) the nation was to elect its ruler from among the issue of Arpád. This rule continued in force even after Hungary had become a kingdom. When the male line had died out, the Hungarians chose their sovereign from the descendants of female branches, on the principle that the blood of Krpád in the veins of these descendants entitled them to the throne. In later years, when they elected Charles Robert of Anjou as king of Hungary, they conferred the right of succession upon his family in perpetuity.

Yet the nation contrived to harmonise the right of election with this law of succession. Even though the ruler was to be of the house of Xrpád, the people reserved to themselves the right of deciding which member of that family should succeed. In practice, the king's brother usually succeeded during the earlier centuries, while in later times it was the son.

On the extinction of the Arpád line, the right of election came still more to the front. When Andrew III. died (1301), the Hungarians observed that the Angevin claimant considered his right to the throne indisputable, and they therefore passed him over in farour of another claimant who was willing to submit to election. Even when Charles Robert gained the throne, the nation laid stress on the fact that he owed it to election. His son, Louis the Great, was also elected to be king, and in several documents he declared that in addition to his hereditary right, he owed his throne to the pleasure of the nation. He showed, too, his respect for the principle of election by requesting the nation to elect his daughter Mary as his successor. The people's right of election becomes still more evident when we remember that Louis asked the nation, in addition, to elect his son-in-law, Sigismund, who had no hereditary claim whatever.

In spite of this, however, Mary had chosen to regard her right to the throne as based entirely upon inheritance, but afterwards, when involved in difficulties, she was 


\section{DEIELOPMENT OF HUNGARIAN LIBERTY.}

compelled to admit that she owed her crown to her election by the nation.

Sigismund, although he had been raised to the throne entirely by the people's free choice, endeavoured three times to fix the succession autocratically, but he soon had cause to repent his action, for it brought his throne into danger. He was wise enough to learn by experience, and during the latter part of his reign never again sought to infringe the nation's right of election. In bequeathing his possessions, he did not endearour to dispose of the crown, but merely begged the Iungarian nobles to be pleased to elect his daughter and his son-in-law, and this request was complied with.

Although, therefore, the nation had conferred the right of succession upon a certain family, yet it retained the right of election within the limits of that family, and no member of the reigning house might consider himself king until he had been duly elected and crowned. No monarch could bequeath his right to the throne, without the nation's consent, and even the claimant with the best title had still to wait for the nation's decision. Though it may have been the people's duty tu elect someone, yet if they neglected to do so, the claimant could not regard himself as king.

In Elizabeth's day the situation was as follows: The Hungarians had undoubtedly conferred the right of succession upon the house of Charles Robert, and as they no longer looked upon Elizabeth as their monarch, and as she herself did not claim such recognition, her son Ladislas was the natural heir to the throne, and had as good a right to claim to be elected as Louis, Mary, and his mother Elizabeth had possessed. Irhen the nation, in face of these circumstances, elected the Polish prince Wladislar as king, it ceased to act in accordance with tradition. On the other hand, the demands of Queen Elizabeth were illegal. Ladislas was not king without election, as until election there could be no Hungarian king. The attitude of neither party to the contest was in 


\section{PERIOD OF DISINTEGRATION.}

accord with written law, yet as the dynasty exceeded its constitutional rights the action of the nobles was only natural.

The nation would not have been what it was if it had surrendered its rights. It was not merely blind devotion to an abstract principle which induced it to cling to the right of electing the monarch, but a clear perception of the important interests at stake. The blend of hereditary succession and free election exactly answered the needs of the mediæral community. One of the chief conditions of national prosperity during the middle ages was that the monarch should be talented and of full age. The reign of a child was a far worse evil than any breach of the rule of hereditary succession. Noreorer, in that age, even the unquestioning acceptance of the principle of inheritance did not assure to a country that freedom from internal unrest which it gives to-day, and which is its chief merit. The problems of succession caused more bloodshed in England than ever the contests attendant upon elections of the monarch caused in Hungary. The WVars of the Roses, and the endless strife between England and France, were originated by disputes regarding succession.

In that day profound reneration for legal rights was unknown, and the right to the throne was no exception to this rule.

It was just in connection with this highest privilege that the right of the stronger prevailed most of all. It is true that the right of electing the monarch is a dangerous weapon, and furnishes opportunities of disturbance, yet the Hungarians knew how to use it, and the frequently recurring crises were not due to any abuse of this right, but to the circumstance that so many kings died without leaving any heir.

The nation realised that the retention of this right was the best safeguard of its liberties. At this day of firmly established and highly developed constitutions such 


\section{DEVELOPMENT OF HLNGARIAN LIBERTY.}

a guarantee is not needed, but then it was valuable as the most effective and yet peaceful means of keeping the monarchy subject to the nation's influence.

The king had to conciliate the people in order to get them to clect the successor he desired, and at his election he had to make solemn promises. The right of election prevented far more bloodshed than it caused, especially in a country like Hungary, where the only defence of the constitution was the sword. In Hungary, among a people which in later times has slanderously been called a rebelliuns nation, and where the right of armed resistance was a main point of the constitution, the monarch dwelt in much greater security than in England, a country which for more than two centuries has not known civil war, and which did not introduce into its great charter the right of taking up arms against the monarch.

England had eight kings from the death of Edward 1. to the advent of Henry VII. (1307-1455), while Hungary had ten kings from the close of the Arpád line to the advent of the Jagrellos (1301-1490).

In England, five of the eight were violently deprived of their thrones and even of their lives. In Hungary, three were expelled from the country, two of them, however, Wenceslas and Otto, having only been the choice of one party, while the third, Mary, was restored. Only one Hungarian king was killed, the usurper Charles the Little. There is good reason for ascribing this comparatively favourable state of affairs in Hungary to the maintenance of the right of election. The knowledge of that right made kings more careful and rendered armed resistance to a great extent superfluous. Certain it is that the nation clung tenaciously to the right, and had it not done so on the occasion of the claim that the Habsburg Ladislas should succecd, it would have suffered grave disadvantages. Hungary must have abandoned its alliance with Poland, and instead of a man, must have accepted as its ruler a baby, at the very time when war was threatening and when a strong leader was needed above all things. 


\section{PERIOD OI* DISINTEGRATION.}

The nation salw, too, that if it surrendered to the Habsburgs its right of election, it could never regain it except at the cost of untold bloodshed. Charles Robert was a powerful king, whose strong rule was not resented by the nation, fet even he could not induce his subjects to abandon this right. It is not likely, therefore, that they would be willing to yield it to a weals woman and her foreign relatives. The more rigid the attitude of the Habsburg family, the more stubborn the resistance of the people. Unlawful demand was answered by unlawful deed, and ignoring Elizabeth's opposition, the nation crowned Wladislav king in the year 1440. It chose rather to depose the reigning house than to brook any infringement of its rights.

All powers and institutions are derived from the nation, and while in ordinary times every organ of the state has its prerogatives and recognised sphere of activity, yet in times of crisis when the nation is likely to get into difficulties by keeping too closely to precedent, the supreme will is that of the people, who alone have the right to cut out a new path and create new legal sanctions.

The ill-conceived effort of the queen and her foreign advisers to deprive the nation of its right, simply led to the result that the aristocracy gained the upper hand entirely, and the royal power became absolutely dependent upon them.

The nobles did not abuse their power, and success did not make them forget, as had happened in many other countries, that they could not hope for prosperity and progress without a strong leader. They had sought for a strong ling in Wladislav, and when they had crowned him, in defiance of the Habsburgs, they did their best, both in their own interest and in the interest of the nation, to make his reign successful. Before his coronation, the new ling solemnly confirmed all the rights which the nobles deemed important, but the constitution underwent no change such as might have proved an obstacle to efficient government. The nation did not surrender its 


\section{DEVELOPMENT OF HUNGARIAN LIBERTY.}

liberty but it realised that only a strong government could protect the country from the Austrian party and successfully prosecute the war with the Turks.

Wladislav was the very man for the position, chivalrous, high-minded, courageous, and entirely worthy of the nation's confidence. The outlook seemed bright, when suddenly the country's hopes were destroyed by the battle of Varna (1444), where the victory was gained by the Turks, who proceeded to take possession of a part of Southern Hungary. That battle prevented the nation's policy from bearing its anticipated fruit. The vigorous king, whom the country so badly needed to reconcile freedom with strong government, came to an untimely end on the battlefield. Once more the throne was vacant and the nation confronted with the same difficult problems that it had tried to solve four years before. The hand of fate was indeed heary upon Hungary. Perhaps, however, it is this constant recurrence of danger and difficulty which accounts, at least to a great extent, for that patriotism and self-reliance which have ever been characteristic of the Hungarians and to which they owe their very existence as a nation.

The battle of Varna was one of the most tragical events in Hungarian history. It happened at a time when the nation scemed on the road to prosperity, and turned to evil efforts which otherwise would have resulted in good.

During the Middle Ages freedom was separated by but a narrow barrier from anarchy. Very little was required to turn the harmonious activity of the nobles into selfish strife one against another. A few men, owning troops and inpregnable fortresses, were so powerful that their unbridled ambitions were enough to plunge the nation into discord and put a stop to the country's healthy development.

Grave dangers could arise even where the bulk of the people remained faithful to law and order and the government pursued the best of policies. How likely, 


\section{PERIOD OF DISINTEGRATION.}

therefore, was it that a country should get into a lamentable condition where a succession of disasters tended to destroy all order, and where the very power whose task it was to maintain order had itself to be reconstituted again and again. In England the order of the state broke down without such unfavourable incidents. How could Hungary avoid her fate with all those unlucky events coming one after the other?

The aristocracy had been divided into two parties by the election of IVladislav, the majority supporting that prince, while some favoured Ladislas. The king was not able, during his brief reign, to reconcile these conflicting elements. Under the protection of Frederick of Habsburg several Hungarian and foreign nobles in the west and north-west of Hungary, maintained their independence of the recognised government. Unanimity was necessary to make the policy of the majority effective and really serviceable to the nation, but the central government was to some extent crippled by this disaffection.

Time and national prosperity were needed to bring about unity, and the battle of Varna threw everything into confusion again. The child rejected in farour of Wladislav was again the only heir to the throne. If he were again to be slighted, party differences would grow still more acute and internal peace be farther off than ever. With the Turks at the door, such a policy was extremely dangerous. Was it wise to repeat the experiment which had terminated so disastrously, especially as there was no candidate so suitable as Wladislav had been?

If, on the other hand, they accepted Ladislas, they would have to abandon the principle of free election and acknowledge as king a young boy who was almost certain to fall under foreign influence. A child king boded no more good to the country after Varna than before it.

Amid all these perplexities the nation fortunately again struck the right path. It unanimously elected l.adislas as king, in spite of the fact that the step might 


\section{DEVELOPMENT OF HUNGARIAN IIBERTY.}

involve in difficulties those who had formerly been prominent supporters of IVladislav. The predominant motive for this action wats to avoid "still greater evils resulting from internal unrest and civil war." This resolution was adopted without any enthusiasm, in a purely opportunist spirit, as it was seen to be best under the circumstances. Steps were taken, however, to defend the country's interests. Ladislas was griven the title of duke; that of king was only to be conferred after his coronation. His election was subject to the condition that the Emperor Frederick, who had retained the crown in his possession, should hand it over, and should terminate his guardianship of the boy. As the adherents of Ladislas agreed to these stipulations, it was to be hoped that a settlement would be arrived at.

But the Emperor refused to part with the crown and to let the boy out of his keeping, and demanded an unconditional acknowledgment of the hereditary rights of the Habsburgs. The characteristic feature of the Habsburgs, which has enabled them to pass through many adrersities and remain for centuries one of the most powerful factors in European politics, namely, their tenacity of purpose, their fanatical belief in their rocation and the divine origin of their authority, has at the same time inrolved them in the gravest dangers.

What were the Hungarians to do? Surrender to the Habsburgs, or throw over Ladislas and find another king, electing perhaps one of themselves? Both solutions had their adrocates. Ultimately it was decided to establish a temporary government, and while still regarding Ladislas as king, await his coming of age and the termination of Frederick's guardianship.

This plan was made practicable by the eminent qualities of John Hunyadi, the chief adviser and confidant of the late king. In him the nation found its natural leader and providential support. The country had but to follow him and it could face any danger. The gentry succeeded in electing Hunyadi as Governor of Hungary. The class 


\section{PERIOD OF DISINTEGRATION.}

which since the death of Andrew III. had remained in the background now stepped to the front through this act. During the Angevin period the gentry gave support to the king without desiring to play a leading part or pursuing an independent policy. Since then they had acted under the leadership of the magnates. Now, however, that the great nobles endeavoured to take advantage of the troubled situation, and began to war with one another, the bulls of the nation determined to assert itself and secure influence in the direction of affairs. Means were not lacking for this. The magnates could not deprive the gentry of their rights. The national council remained the chief organ for realising the public will, and on that council the gentry could always obtain a majority if they cared to attend its meetings. A sound instinct prompted the choice of the greatest soldier and noblest man in Hungary as the nation's leader, yet in order that the step should prove a success it was needful to place regal powers in Hunyadi's hands, and to obey him as Louis the Great had been obeyed. The country could only hope for prosperity if a great man stood at its head, enjoying full freedom of action, one who could make the nation forget the absence of a king, could defend the: frontier against the Turks, and compel Frederick to send Ladislas back to Hungary, to be brought up under Hungarian infuences. Unfortunately the nation was not wise enough and well-disciplined enough to adopt the only satisfactory course. Party strife, that foe to Hungarian prosperity and liberty, had not ceased, and the jealous Estates would not give Hunyadi the power necessary for its suppression. Many of the magnates hated the idea of a member of the gentry attaining to such an exalted position, some preferred an unsettled state of the country as it offered them a better chance of furthering their individual interests, while others, being of foreign origin, took little interest in the welfare of the nation.

This disunion was more disastrous for Hungary than for other countries, for it endangered the racial supremacy 
of the Hungarians. Powerful foreign noblemen like Giskra or Cillei not merely were harmful to those whose property they took by force, but tended to destroy the sentiment of nationality. Had their influence endured they would have created a kind of independent German or Bohemian state on Hungarian ground.

In these troubled circumstances a strong central power was needed. However brilliant the halo surrounding the name of Hunyadi, it could not altogether make up for the lack of the monarch's traditional authority. Not merely the magnates, but the gentry also, esteemed his commands less highly than if they had proceeded from a successor of St. Stephen. Greatness of character was not quite so effective as the dignity of a king. The nation should have done all in its power to increase the authority of Hunyadi, but it took the opposite course. As in the days of Andrew III. the nobles tied the hand which should have laboured freely in the country's behalf, and the melancholy spectacle was to be seen of a great man devoted to lofty aims, yet deprived of the means of achiering them.

When Hunyadi was made Governor, six "Captains of the Realm" were appointed whose powers tended to destroy the centralised character of the government. The Governor was not allowed to give away any large estates. In any case of disloyalty he could neither condemn nor pardon the offender without the permission of the Diet. He was not empowered to invest any ecclesiastic with the dignity of archbishop, chief abbot or bishop, without the advice of the Council elected to control his actions, and it was the Diet which filled the various offices under the State simultaneously with the appointment of the Governor. It is evident that Hunyadi's task was rendered exceedingly difficult by all those restrictions. Furthermore, his adversary Garai was elected Palatine, and a still greater mistake was made by the Estates when they decided that the Diet should elect the Governor and the other high officials annually. This decision crippled 


\section{PERIOD OF DISINTEGRATION.}

the authority of the government and meant practically the immediate rule of the Estates. Fortunately the law appears never to have been put into force, yet its very existence was damaging to the dignity of the government.

While the Estates displayed such a grudging spirit towards Hunyadi, they laid great stress upon their own rights. They revived the law that military service could only be demanded of the nation if the royal troops and the official banderia were not sufficient. 'They also passed a law freeing themselves from the payment of all tolls. They increased their privileges and lessened their duties. They secured extended political influence by a law to the effect that one half of the Council was to be elected from their ranks and that in the event of the death of Ladislas, his successor was to be elected by the Diet. In short, instead of endowing Hunyadi with large discretionary powers, the Estates placed him entirely under the control of the Diet, in which they had the leading place.

The aggressive behaviour of some of the magnates stirred the gentry to resistance. It was necessary and salutary that the gentry should come to the front, for their aims were excellent though in their action they often displayed little sagacity. At a time when freedom was in no danger and when the one thing the country needed was to become strong and united, they sanctioned laws which tended to create division. The obstacles placed in the path of Hunyadi were probably due to the influence of a few great nobles, but if the gentry had understood their own position events might have taken a different turn. The gentry were able to increase their own power, for they had influence enough to determine the number to be elected to the Council from their own class. It was due to them that the sphere of activity of that institution was widened. One thing, however, they could not or did not do, and that was to assure for Hunyadi as much power as he needed.

This omission brought its revenge, for the sound policy for which Hunyadi and the gentry stood failed of 


\section{DEVELOPMENT OI* HUNGARIAN LIBERTY.}

its desired result. Hunyadi tried first to secure the person of the young ling by force, and when that attempt failed, and when the unlucky battle of Kossovo polje (1448) in which the Turlss were victorious, had crippled the country's strength, he adopted a fresh policy. He entered into a contract with Frederick in which the Emperor recognised the governorship of Hunyadi, and it was agreed that Ladislas should remain with the Emperor until he came of age.

This contract served the useful purpose of aroiding the terrible calamity of the reign of a child ling who was under foreign influences, and it also assured the governorship of Hunyadi for several years and helped to establish peace on the western frontier. But still Hunyadi was not quite master of the situation. The Estates demanded that the young king should be sent to Hungary, and thus pursued a policy in contradiction to that of Hunyadi. Either policy might have yielded satisfactory results if consistently pursued, but divided councils inevitably entailed failure.

Had the nation unanimously adopted Hunyadi's plan, the young king would have remained at the Court of the Emperor Frederick and the reign of a minor would have been aroided.

On the other hand, if the policy of the Estates had been energetically pursued and the Emperor had been forced to hand over the young king, a Hungarian guardian could have been appointed and the Estates would have had the supreme power.

As it was, the Estates made it impossible for Hunyadi's scheme to be carried into effect, and yet sufficient energy was not shown to force Frederick to comply with their demands. It was not to the Hungarians that the Emperor confided the boy, but to Czillei, an Austrian, the worst possible result to which the many good intentions and efforts could have led. The misfortune of being governed by a minor was increased by the circumstance that the child's guardian was a hated and evil-minded 
alien. The nation had brought this trouble upon itself as a punishment for its treatment of Hunyadi.

Ladislas annulled the acts of Wladislav, and reckoned his reign from the year of his birth. The Estates ceased to claim the right of election and acknowledged the validity of the Habsburgs' contention. What had induced them to accept this worst possible solution of the nation's difficulties and to put on one side Hungary's greatest son? It was chiefly the efforts of a few great nobles, who were adversaries of Hunyadi. That they could succeed so easily was due to the fact that the nation did not ask who was to blane, itself or Hunyadi, for the unsatisfactory situation in which the country found itself. People demanded success, and, if success was not achieved, they turned for help to the prestige of royalty and were unjust even towards so great a man as John Hunyadi. Many perhaps hoped that Hunyadi would still remain at the head of affairs, and that he would acquiesce in the new form of government. They knew at least that he would not endanger the country's order. Perhaps he himself believed that he could retain his influence.

Ladislas $V$. commenced his reign under favourable auspices. Thanks to good advisers and the support of Hunyadi the royal cause was in the ascendant. The recent troubles had given rise to a powerful reaction in favour of the monarchy. The Hungarians saw how indispensable the royal power was, and this induced them even to accept the king's unpopular guardian Czillei.

But the king could not make a good use of the situation. His court became a centre for intrigues and his very presence added to the trouble. The nation was entangled indeed among difficulties, with a selfish great nobility, a gentry incapable of leadership, and a minor king, intentionally spoilt and made capricious. At first, Hunyadi tried to take the reins into his own hands, but he found to his sorrow that the king was less trustworthy than the Estates. Sometimes he paid no heed to Hun- 


\section{DEVFLOPMENT OF HUNGARIAN LIBERTY.}

yadi's words, sometimes he intentionally offended him and sought for allies among Hunyadi's enemies. Now it was the king who decided about the nation's affairs, now it was Hunyadi, and now the Diet.

Ladislas entrusted the administration to six magnates, six prelates and six members of the gentry, all of them elected by the Diet, and yet when Hunyadi appealed against this arrangement, the king set him above those men. Some of the magnates formed alliances and wielded a greater influence than the lawfully constituted authority.

Fortunately the Hunyadi family had considerable wealth and military power, and these being used entirely for the common good, proved the bulwark of the nation.

Hunyadi endeavoured to atone for the ruler's neglect. While the king and nobles were carrying on their intrigues, and in the war against the Turks never got beyond the stage of preparation, Hunyadi acted and defended with wonderful valour the territory and the honour of the nation.

Unfortunately for Hungary, Hunyadi's life was drawing near its end. He fought his last battle at Belgrade, where he saved his country and Christendom, and soon after the victory he died (1456).

Hunyadi had not been able to stop entirely the disintegration of the country, but he had succeeded in warding off the chief dangers by which it was threatened. While he lived he heroically defended his country from the invader, while at home civil war was made impossible by the fear and respect with which all men regarded him and by his careful avoidance of any aggressive conduct.

But when he died the whole state was shaken to its foundations. Ladislas Hunyadi stepped into his father's place and a close alliance between him and the young king might have saved the country. This perhaps was hardly to be expected, for the king, who had not liked to see the old hero at the head of the nation, was still less likely to allow Hunyadi's son to have so much power. Ladislas Hunyadi unfortunately was more vehement than 


\section{PERIOD OF DISINTEGRATION.}

his father and more easily impelled to actions likely to cause strife. The nation adored the young hero, but the king did not trust him and gave the preference to the alien and hated intriguer Czillei, who at least did not endanger his crown. A conflict was inevitable. Czillei, jealous of the people's favourite, persuaded the king that he was seeking to gain the throne, and ultimately Ladislas Hunyadi was arrested and beheaded. This threw the country into an uproar and the king fled to Prague. Had he lived, civil war would have been inevitable. Fortunately, a year after Ladislas Hunyadi's death, the king died (1457), and Matthias Hunyadi, the brother of Ladislas and the younger son of the great John Hunyadi, was elected by the nation to the vacant throne.

The dreadful entanglements into which Hungary fell were the result of weakness at the centre. Without a strong government there can be no prosperity or advance even in a free state. The nation which determines to be free must keep the government under its control and restrict the limits of the executive power, or else it may fall into the power of its leaders. On the other hand, by pursuing this policy too vigorously it runs the risk of enfeebling the government and of making it the sport of every fickle gust of public opinion. Even to-day there is hardly any state in which the government should be entirely under the control of the people, and where the community should not depend at all upon the will of the central authority for its privileges. Perhaps England is the only country where such a state of things has obtained; but there the problem is rendered easier by the circumstance that the government needs less power than is necessary in Continental states. France has been struggling for a century to obtain liberty together with the order which demands a strong hand, but she has not achieved her aim. She has merely had freedom and strong government alternately. In the first and second Republics, the overpowering demand for freedon made effective government impossible, so the inevitable reaction 


\section{DEVELOPMENT OF HUNGARIAN LIBERTY.}

occurred. The Republic had to give way to the absolutism and centralisation of the Napoleons. The monarchy and the third Republic made serious efforts to unite the two great interests of the nation, but with negative results. France has not a strong government even to-day. The successive governments fall under the influence of small factions, whose intrigues and petty jealousies, which they try to hide beneath the great words democracy and equality, often shut out from power some of the nation's finest men. Naturally such a state of affairs cannot lead to a strong administration, nor is a strong organisation of the army possible. Only in its matters of foreign policy can French sentiment be united.

In Hungary also, strong government and freedom are not yet attained, although the political education of the people is much more advanced than in France.

The task is much more difficult in Hungary than in England. Perhaps no country needs energetic government more than Hungary. The general European situation, her connection with Austria, her comparative poverty, and the mixed character of her population, all make a strong-handed and far-sighted government necessary. Hungary has not lacked such governments, but their strength has been purchased at the cost of liberty.

Parliamentarism has been developed upon sound lines, and perhaps no nation makes a better use of its representative institutions. Public opinion and national sentiment are so influential that no anti-national tendency could ever prevail. Racial feeling is so strong that it is impossible to imagrine a Hungarian majority which would intentionally injure the nation's interests.

Yet the degree of freedom attained is not satisfactory. The Hungarians enjoy the privilege of freedom from foreign domination, but as much can be said for countries like Russia or Turkey where tyranny crushes the people.

Real freedom is still wanting in Hungary because the community is weak and not sufficiently independent of the government. Statesmen saw that a strong hand was 


\section{PERIOD OF* DISINTEGRATION.}

necessary and tried to make the people dependent upon the State. Even the economic development increased the influence of the government. The administration became centralised to an excessive degree. Hungary was so glad to see that she was ruled by her own sons again and that her cherished constitution was restored, that she was no longer jealous of her governments and looked on quietly while the army of officials grew and the economic enterprises of the State increased in number. In many countries such a course would have led to open or clandestine absolutism, but thanks to the Hungarians' innate love of liberty, their great traditions and strong political instincts, they have been enabled to realise to some extent the idea of true autonomy. But the nation cannot rest content with its present achievement. It will be the work of the future to increase the independence of the community and to raise the general level of the nation's intelligence so much that Parliament may gain increasing importance.

Perhaps, as a result of gradual development, a really independent community will be evolred which can establish a government not lacking in strength and fully able to answer the requirements of its vocation.

During the Middle Ages it was exceptionally difficult to strike the right path. Then more than now it was necessary that one weighty, brilliant and imposing personality should lead; that the work of politics should be entrusted to a few, and that the executive power should be in one hand. The abstract notion of law and of the State, had little hold upon the mind of the masses. Their ruler could not be one whose dignity was borrowed entirely from such abstract conceptions, but a man surrounded by the visible signs of grandeur and encircled by the halo of " clivine right." Only such a ruler could they love and revere. To lead people then it was necessary to impress them. That was why the Roman Church attributed such importance to outward magnificence. It is not surprising therefore that the government lost its 
authority directly the ling was placed in the background by Parliament.

Government during the Middle Ages was little else than preparation for war and the prosecution of it. Force was the means adopted both by the disaffected and by the government.

In internal affairs, success either for king or noble generally depended upon the ability to act quickly and vigorously. If a man could do this he was sure to be more successful than a whole Parliament or similar body where the decision rested with the many. It was for this reason that the Diet of Andrew III. was unable to deal successfully with the Counts of Németujvár or with Matthew Csák, while the individual will of King Robert Charles speedily brought them to order.

The Hungarian Diet did not possess sufficient power to enforce its decisions, as the government was supported only by public opinion as expressed in the Diet and not by king or magnates. The minority were not disposed to acquiesce loyally in the decisions to which they were opposed, and it remained for the majority to show they had strength enough to enforce them. If the banderia of the king and magnates were not lent for the purpose of executing such decisions these were apt to remain a dead letter.

Moreover, it was very difficult to make the Diet truly representative of the whole nation, as there were such great inequalities in wealth and social standing. The great noble had so many means of acquiring political influence that it was a farce to pretend that his word carried only as much weight as that of his poorer neighbour. Accordingly the Diet has frequently fallen under the influence of a few powerful members of the community, as the political interest of the bulk of the nation has been too feeble and uncertain to sway the assembly. It must be remembered, too, that many of our present institutions did not then exist. There was no press; frequent communication between different parts of the country was impos- 


\section{PERIOD OF DISINTEGRATION.}

sible, and there were no well-organised parties carrying on their unceasing activities. The Diet was not suited to the task of controlling the government and its policy, for it had not at its back a powerful public opinion. All governments were weak which found their chief support in the Diet and were opposed to the king and the magnates. The Diet was never able to sit for very long. To attend for months or perhaps years meant so much expense and inconvenience as made it impossible. Successive Diets were not in any organic connection and scarcely knew anything of each other's actions. Governments inaugurated by the Diet were only stable so long as the body which created them remained in power.

A government can only gain strength from permanent factors of the nation's life, and the governments in Hungary were only effective when they were in harmony either with the crown or with certain powerful groups of nobles. John Hunyadi owed his position to the gentry, but he could not have maintained it if he had not been on good terms with the magnates.

The efforts that were made to empower the bulk of the nation to govern itself by means of the Diet and to replace the monarchical régime by the immediate rule of legally constituted bodies, were premature and were bound either to collapse utterly or to cause the power to pass into the hands of a few wealthy nobles.

For a short time this government by the great nobles might produce good results, but in the long run it led to disorganisation. Nobles like those of England and Hungary who kept in touch with other sections of the community might for a time govern the country well in the absence of the counterpoise of royal power, as happened during the reign of Sigismund; but ultimately the temptations inseparable from such a condition of affairs were certain to prove too powerful. It was inevitable that selfishness should lead the nobles to seize the opportunity of self-aggrandisement.

Mediaeval parliaments were able to put an obstacle in 
the way of unlawful action by the king and to take an active part in the work of legislation; they could support governments or procure their dismissal, and could fix a limit to the sacrifices which were to be demanded of the nation, and thus gain an indirect infuence in political matters; but when they attempted more than this they failed, and their efforts generally led to the rule of the great nobles, which became more and more tyrannical.

This result followed both in England and in Hungary directly the reins of government slipped from the weak hand of the monarch. It must, however, be acknowledged, in spite of the similarity of events in the two countries, that the Hungarians exercised more self-restraint than the English. In England parliamentarism only produced good results while the personality of some great bing counteracted the unruly spirit of the Estates.

In Hungary this was not the case. The nation only had one king who could be compared to Henry IV. or Henry V. Sigismund and Albert only reached mediocrity, and IVladislav, who was a great personality, died shortly after ascending the throne. Those kings, moreover, were not able to devote all their time and energy to Hungary, as they possessed other dominions, so that the efficiency of the government, while it lasted, was very largely the merit of the Estates. What England could only gain with the help of some great king, the Hungarian Estates achieved themselves. The period which commenced with the struggles of the nobles against the despotism of Sigismund and issued in the régime of Garai, will always remain a proof of the nation's political wisdom.

The moderation of the Hungarians was conspicuously displayed on another occasion. The situation was very much the same in England and in Hungary. In England, when a minor ascended the throne (1422) the avalanche descended at once, annihilating the entire system of mediaval parliamentarism. The nobles came 


\section{PERIOD OF DISINTEGRATION.}

into collision with one another, and a civil war followed without the nation trying to put an end to the trouble.

When a similar event happened in Hungary and a child became heir to the throne (1440) the Estates used drastic measures indeed, but with great political insight. Instead of striving to gain unlimited power, they sought to impose a bridle upon themselves.

They saw that they needed a strong leader and they found him in Wladislav. If in spite of this the monarchy grew weak the fault does not lie at the door of the Estates, but was due to the unlucky battles of Varna and Kossovo polje and the obstinacy of the German Emperor who would not allow the young prince Ladislas to return to Hungary as its elected monarch.

In England, internal disorder preceded the external catastrophe, while in the case of Iungary blows from without created internal weakness and disunion, and in spite of them, the final scene of the tragedy might never have been enacted if Ladislas $V$. had been as good natured and as easily led as Henry VI. The nation realised the danger arising from the weakness of the monarchy, and the young king, if he had possessed tact, could have made profitable use of the disposition in his favour.

While in England the place of the royal power was taken by that of the nobles, in Hungary it was the gentry, who with Hunyadi at their head, stepped into the gap and by their devotion surrounded their country with glory in spite of its disunited state. Their conspicuous patriotism may be accounted for partly by the danger in which Hungary stood, but partly also by the fact that circumstances had forced the gentry class to the front and assigned to it important duties in the counties, although in the Diet itself it had less scope than was the case in England.

The period we are considering did not yield such lasting fruit in Hungary as in England. Parliament was the chief organ by means of which the English privileged classes asserted their will and they accordingly developed 


\section{DEVELOPMENT OF HUNGARIAN LIBERTY.}

and carried to a high pitch of excellence its internal organisation. The Hungarian Diet, however, had not yet taken a form which fitted it to be the organ of a highly developed state life. Only on rare occasions were important political questions settled in the Diet, and its procedure was not perfected to the same degree as that of the English Parliament. Nevertheless, the age, so rich in events, left deep traces behind it.

It was at that period that the national assembly underwent certain changes. Sigismund invited representatives of the towns to attend its sittings and thereby gave it a broader foundation. Still more important was the circumstance that especially since the time of Sigismund, personal attendance of members of the noble class became less and less frequent, and they began to exercise their legislative rights by means of elected representatives.

The other state organ, the royal council, was still flourishing. The king, or governor, laid all political questions before it, asked its opinion and usually followed its advice.

The importance of the royal council and of the Diet was largely due to the power of a few members. A body which comprised men like Ujlaki, Garai, and Hunyadi, could not but be influential even if its constitutional rights were few and it could not claim to represent the whole nation or boast of great traditions. Such military strength was behind them as to give weight to their decisions.

Though the achievements of a griven period may not be of a permanent character, yet their memory lives on as a precedent. The high position gained by the Estates and by the Diet established in the mind of the nation the conviction that only a state founded upon the co-operation of king and people could meet the country's needs. When in later years the royal power grew too great and kings tried to legislate for their own benefit, the nation only regarded that constitution as lawful which was in 


\section{PERIOD OF DISINTEGRATION.}

conformity with ancient traditions. Those traditions did not die and whatever conflicted with them, even though the Estates gave it their assent, was deemed an infraction of the nation's rights. 


\section{CHAPTER XI.}

\section{REACTION IN FAVOUR OF THE MONARCHY IN ENGLAND. THE TUDORS.}

The conclusion of the IVars of the Roses was a turning point in the history of England. During the long conflict, which had lasted for two generations, the nobles were so powerful in consequence of the weakness of the king, that they were not inclined to respect the law. There was a Parliament which was adequate to the peaceful settlement of disputes, and there was a self-respecting gentry, well versed in politics, which had more to lose than to gain by civil war, but these were not enough to confine the contests of the nobles, who possessed all the means for carrying on war, within the limits of peaceful rivalry.

The gentry had not the strong organisation and the military power which could curb the ambition of the nobles, and as the king also lacked the needful strength, peace could not be maintained.

This experience was wholesome for the king. Moreover, his path was made easy by the long continued anarchy. The warlilie nobility was pouring out its lifeblood and many ancient families became extinct while their estates became the property of the crown. The weakened feudal aristor "cy fell into the background, and the gentry, which had till then been led by the nobles, was not yet strong enough to take the place thus left vacant in the organisation of the State. Although the gentry had been well trained in the school of politics, and although in Parliament and in the work of administration 
it played an important part, yet it did not aspire to the foremost place. It longed for peace and wished to carry on its various pursuits under the protection of the ling. Formerly, the king had been surrouncied by men with an insatiable desire for power, but these were now replaced by men who, in order to secure the satisfaction of their more modest requirements, gladly left the leadership to the king.

Another turn of events had a great influence upon the internal development of the colintry and faroured the cause of the monarch. During the wars with France large military forces had to be kept in readiness and the relations of the various factors of the State and of society were largely determined by military considerations, but as France became stronger and the aggressive wars came to an end, a great standing army became unnecessary.

The king's relations with the robles had been influenced considerab!y by the circumstance that he needed troops and money, and that he could gain both only from the aristocracy. The Plantagenets and the Lancastrians defended themselves as well as they could from the exaggerated power of the nobles, but they could not destroy the evil at its source by breaking the military power of the nobility. Now eren this becane possible. The root of the nobles' power withered as soon as they could not maintain armies. Their forces consisted largely of the knights errant who joined them voluntarily and of the lesser nobles who sought their protection. These entered the service of some great nobleman; they wore his coatof-arms and colours and placed themselves as well as their affairs under his patronage. This system grew to such an extent as to make the impartial administration of justice impossible. Also, the great nobles gained thereby enormous military power. The king had to submit to this because he could not move without the troops of the nobles. Richard II. consented to wear the colours of his; brother. But during the peaceful epoch which followed, the situation was entirely changed. 


\section{DEVELOPMENT OF HUNGARIAN LIBERTY.}

The Yorkists and the Tudors enacted severe laws against the livery system. The armies of the barons were disbanded, and with them disappeared the exaggerated power of the nobility.

With the advent of peace another weapon of the privileged classes also became powerless. An army being no longer required war taxes had not to be levied and consequently it was not necessary to summon Parliament. There was no law which settled the question of Parliamentary influence over the executive. The privileged classes had not succeeded in making the royal council, that is to say the actual government, dependent upon Parliament. It was only occasionally that Parliament could exercise control over the executive, generally when taxes were required. It therefore had important consequences that the king rarely needed taxes. The executive became independent of the privileged classes and, being strongly organised, became the chief factor in the state. The laws themselves did not change, yet first Parliament gained the upper hand over the government and afterwards the royal power became greater than that of Parliament itself. The pirot of the kingdom was first in Parliament, which was independent of the king, but afterwards we find it in the person of the king and in the council dependent upon him alone.

In consequence of the internal wars, public opinion had veered round towards the Tudors. The feudal aristocracy had become weak and had no armed forces, while the gentry did not seek the leading part. The kings were not dependent upon the goodwill of Parliament. All these circumstances enabled the Tudors to acquire such power as had not been possessed by any other English morrarchs since the time of the first Norman kings.

The great movement which had commenced in the thirteenth century, in the direction of restricting the power of the king, had come to an end. 'The monarch regained almost all that he had lost. He rarely summoned Parliament, and even if he did, he controlled its decisions. He 


\section{MONARCHICAL REACTION IN ENGLAND.}

influenced the very constitution of Parliament and decided who should be elected. Proceedings for which Richard II. had to pay dearly became the custom under Henry VII. and Henry VIII.

The administration of justice became the function of the royal council. The most important legal questions were settled by the king's ministers.

The privileged classes voted the taxes for the whole lifetime of Henry VII., and Henry VIII. secured that all his orders should have the validity of law.

The king's power was so great that he could venture to sever the ties which had bound the country to Rome. Queen Mary restored the old faith to its former position but Elizabeth again placed the church under the supremacy of the crown.

The monarchs took the opportunity of slighting the ancient aristocracy which for centuries had defied them. They surrounded themselves with new men who were indebted to them for all they possessed. Nor did they choose their ministers from the great nobles but from a class inferior to these in birth as well as in fortune. Instead of the Percies and Warwicks they turned to the Wolseys and Cecils, in short to people who were not bound by ancient traditions to the constitution and who professed allegiance to the monarch alone. Wolsey knelt to the king when asking him to alter his intentions, but if the king clung to his decision Wolsey carried it out however wrong he may have thought it.

How differently would the Earl of Warwick have acted. The "kingmaker" would simply have chosen another king.

The Tudors were surrounded by an obedient nation and the royal power seemed unlimited. This, however, was not the case. The king's power was limited by the absence of a standing army. Peaceful times had made the maintenance of expensive military forces superfluous.

The preservation of internal peace was entrusted to the militia, which remained in such close touch with the 


\section{DEVELOPMENT OF HUNGARIAN LIBERTY.}

people that the king could not use it against the nation.

The king was not in a position to compel the bulk of the nation to obey him by any forcible means. If he tried to play the tyrant he was sure to fail as he had no army. Absolutism could not be carried beyond the point at which the opposition of the majority began.

The king could do much but not everything. IVrongs committed against individuals did not endanger his position because the nation was tired of ciril war and was not inclined to take up arms. Only in defence of great common interests would it incur the risls of armed resistance.

The Tudors well knew the limit of their power. Their chief effort was to govern in a way that harmonised with the feelings of the bulk of the nation. 'They were ready even to revoke orders which gave offence rather than provolie a contest.

It was of the utmost importance that the king's acces. sion of porer did not make an end of parliamentary traditions and that, on the contrary, the later requirements of parliamentarism found precedents in the events of that epoch. During the reign of Henry VII. Parliament had very little influence. Henry VIII., however, felt himself so entirely master of the situation that he was willing to allow Parliament to play a part. He knew that he had no reason to fear Parliament, while its corroboration of his decisions would increase their importance in the eyes of the people. By obtaining parliamentary sanction he raised his own will to the level of the common will. The old constitutional idea that the king and the privileged classes together were the source of law was maintained. The important questions of religion and of succession were settled by the ling with the help of Parliament.

In former times Parliament, and especially the powerful nobles, took the initiative in dealing with the great concerns of the nation's life, but in Henry VIII.'s time the initiative was taken by the king. The situation was entirely changed in reality, but not formally, because 


\section{MONARCHICAL REACTION IN ENGLAND.}

Parliament retained its sphere of activity, at least in outward seeming.

Respect for the rights of Parliament did not prevent the Tudors from being all-powerful in their day, but it made it possible that the community should exercise an influence which it could not otherwise have gained, and that with a change of public opinion the ancient liberty should revive.

This was why the rule of the Tudors was not fatal to the cause of freedom. The king's power extended far, yet the Constitution was preserved in its ancient integrity.

The hundred years' rule of the Tudors had two consequences which rather favoured the cause of freedom.

One great erent of the period was the Reformation. At first this augmented the monarch's power. All that had benefited the king in the Catholic church remained unchanged in the reformed church. Like the supremacy of the Roman hierarchy, that of the king also trained the people to obedience. On the other hand, all that was disadrantageous to the king in the Catholic church was absent from the reformed church. But the morement of the human mind which had brought about the Reformation would not halt just where the king wished it to stop. The people submissively followed the leading of Henry VIII. even in matters of religion because their minds were still under the powerful influence of the causes which had led to a revolt against Catholicism and in that revolt they found in the king their leader. But by fostering the spirit of reform, Henry set free living forces which would not long adapt themselves to the monarch's will, and which, in obedience to their own laws, worked a great transformation in the mental life of the nation. The English people, being constantly in touch with the peoples of the continent, became imbued with doctrines which produced an effect very different from that contemplated by the king. The Calvinistic church was organised on the basis of autonomy. That was the first attempt in Europe on the 


\section{DEVELOPMENT OF HUNGARIAN LIBERTY.}

part of large masses of people to govern themselves on democratic lines.

The whole order of the world was changed. The governing power had come into the hands of the lower orders of the people. Dogmas were not passed down from some priestly hierarchy to a submissive flock. It had become a matter for every man's conscience to settle the great problems of faith. The decisive word belonged to the individual and not to any authority above him.

All this deprived the monarch of some part of his influence. New modes of thinking and feeling had come into existence, and sought to become operative in the world of politics as well as in that of religion. They introduced the spirit of democratic government into public life.

Did this guarantee liberty? Not at all. In the name of the sovereignty of the individual conscience men often acted as tyrannically as they did in the name of democracy. Nevertheless, the Reformation proved of immense importance to the cause of freedom. The English Protestants may have become tyrants, but they would not endure the tyranny of others, and for the time being that was the chief danger to be feared. The monarchs wished to maintain the episcopal system and persecuted the Puritans, so that these were driven in self-defence to join the ranks of the opposition. The whole mode of thought of the Protestants was opposed to the notion of the king being supreme in all matters, and if they had ever become advo. cates of absolutism it would certainly not have been royal absolutism.

The great differences between the royal government and the Puritan church destined the new faith to become a powerful support of the cause of freedom, and to put an end to the torpid mental condition which had made the power of the Tudors possible. The Puritan spirit created noble defenders of the freedom threatened by the king and raised such forces as were able to play a decisive part in the struggles that followed. 


\section{MONARCHICAL REACTION IN ENGLAND.}

Other effects of the royal government which checked its subsequent transgressions were the long peace and the increasing wealth of the country, due to a wise economic policy, and, above all, the growing importance of the middle classes. Under the careful hands of the royal government the gentry became entirely transformed. The gentry of the time of Henry VIII. and that which in the last years of the reign of Elizabeth defied the queen herself, and in whose ranks we see men like Hampden and Pym, were two different bodies. The former, though endowed with political ambitions and with a certain measure of influence, did not claim the first place in State life. Accustomed to be led by the aristocracy and acknowledging the necessity for the increase of the royal power, it was willing to leave the settlement of great political questions in the king's hands. But the new gentry aimed higher. It had become rich; the monarch sought its support; ministers were chosen from its ranks, and while occupied with the duties of government it became familiar with great affairs of State. The psychological effect of the events of recent times was gradually cancelled and the old traditions of freedom were revived. The character developed in a united state could not be destroyed in a few decades. During earlier times the monarchy had never reached such a level of impotence that the royal reaction, when it came, should cause such an upheaval as to destroy all the traditions of the nation. The people's self-reliance, which had been diminished through the weakness of the monarchy, revived. Self-respect awoke along with increased capacity for government. The gentry class became so strong that it wished to occupy the leading position which had become vacant through the downfall of the nobles. The burgesses of the towns, merchants and craftsmen, attained a degree of importance in public life of which their forefathers would not have dreamt. The growing culture, evident throughout Europe, the self-reliant thought and action to which the middle classes became accustomed, fostered the idea that a leading part 
in the management of the nation's affairs was due to them.

During the Middle Ages the towns had played a very unimportant part. Influence belonged almost exclusively to the landed proprietors. It was only at the time we are now considering that the burgesses also claimed a part in political life. When making this claim even the little sphere of activity which had belonged to the representatives of their class in former times proved useful. It was then that the tree whose seed had been sown in the thirteenth century bore some fruit. The representatives of the towns had sat for three centuries in Parliament, side by side with the deputies of the counties, and the equality of their rights and the growing feeling of solidarity made common action possible. They sat in the House of Commons not as a separate, isolated class, but as one which was, theoretically at least, equal to the others. Parties therefore were formed on great political questions from the representatives of the towns and of the counties.

The sixteenth century thus left behind it traces of opposing tendencies. On the one hand, great examples of royal government were handed down to posterity, but on the other hand the new generation inherited a more vigorous spirit of liberty.

Such an inheritance is a dangerous thing. He whose insight is keen can discern the transformation in process beneath the surface. But the majority of politicians are not thus gifted. They tread the old paths, not noticing the abyss that has gradually been opening itself beneath their feet, and not till they fall headlong do they realise the presence of danger.

The success of the Tudors awakened in their successors the belief that the nation would obey them as readily as it had obeyed the Tudors. The royal power had vanquished the aristocracy and stood in giddy isolation far above the privileged classes. The king was not surrounded by those dangerously powerful men who in former times had continually reminded the monarch that there were aims and ambitions in the community with 


\section{MONARCHICAL REACTION IN ENGLAND.}

which he had to reckon. In his intimate council, the king did not meet with any opposition. Further, those round about him made him believe that he would not find it anywhere. He saw how the monarch's authority had grown upon the continent and he aimed at equal power. If he cherished the desire to consolidate the practice of his immediate predecessors into a permanent system, collision with the people was inevitable. The nation had awakened to new life and was a formidable antagonist. It was not controlled by the aristocracy, which, though it sought to restrict the royal power, could not really be opposed in principle to the kingship. The aristocracy had formerly been an intermediary between king and nation. Standing near the throne its ambitions and its power could act as a restraint upon the king, and at the same time it could lead the nation in such a way that although the people opposed this ling or that, they were never opposed to the idea of kingship. It is true that the nation dethroned Edward II., Richard II., Henry VI. and Richard III., but in place of the dethroned monarch it chose another.

Now, however, the influence of the aristocracy had become unable to moderate either of the two opposing parties. At no time until the nineteenth century was the aristocracy so impotent as it was then. This circumstance led to a very great divergence between king and nation. The elements that stood at the head of the opposition would not have objected even to the inauguration of a Republic. Against the prerogatives of the king they set the rights of the people and their notions found soil in which they could strike deep root.

The great drama of the seventeenth century had been prepared in the sixteenth century, and the Stuarts were going to see to it that the catastrophe which had been made possible should actually occur. They ran blindly into the danger. The great convulsions into which they threw the country threatened to turn the nation out of the course of development marked out for it by past history, 


\section{DEVELOPMENT OF HUNGARIAN LIBERTY.}

and it seemed as if either the kingship or constitutional freedom would have to be sacrificed.

The final result, however, was the triumph of the great national traditions. Even the wrongdoings of kings could not destroy the strong edifice which had been built up. The work of the Middle Ages was crowned by the new age, which solved the problem with which the Middle Ages had grappled in vain, namely, how to make the executive power dependent upon the people's representa. tives without impeding its wholesome activity. In the State there was one decisive authority, that of the majority of the House of Commons.

But all this happened at a time which cannot be dealt with in this present book, and we must return to the development of events in Hungary during the fifteenth century. 
ROYAL REACTION IN HUNGARY.

\section{CHAPTER XII.}

\section{ROYAL REACTION IN HUNGARY. KING MATTHIAS.}

During the second half of the fifteenth century the course of development took different directions in Hungary and in England. In previous centuries, as we have seen, similar causes operating in the two countries gave rise to similar consequences, and while in some respects Hungary and England differed, yet as regards their constitutional development they displayed many analogies. The inhabitants of the Christian countries of Europe during the Middle Ages were very much alike by reason of the similarity of their culture, their religion, their sentiments and their general conception of life, but in the case of the English and the Hungarians the resemblance was striking and it led to a sinilarity in their political development. In both countries it was the monarchy which preserved the national unity, and as the two nations waged many wars with other countries, internal relations were largely regulated in accordance with military needs.

During the fifteenth century this resemblance came to an end, and a transformation came over the situation in England which had not its counterpart in Hungary. During the Wars of the Roses the English nobles waged at destructive warfare among themselves, while Hungary succeeded in averting civil war, and King Matthias (14581490 ) was confronted by the magnates in their undiminished might. The work which fate accomplished for the Tudors the Hungarian monarch had to take in hand himself. England had reason to be grateful for her geographical situation. The Norman Conquest indeed 


\section{DEVELOPMENT OF HUNGARIAN LIBERTY.}

had established so strong a link between France and England, a connection strengthened by the ambition of kings and the warlike proclivities of the nobles, that England, continually engaged in foreign wars, was in a somewhat similar situation to the purely continental country of Hungary. As soon, however, as France awoke and drove out the English, the situation was entirely altered. Defeat proved a blessing to England and she then reaped the advantages of her insular position.

Lasting peace followed, troops were disbanded and military considerations were no longer paramount.

Hungary all the time was drifting into a more and more critical position. The Turkish peril was becoming ever more menacing. Constantinople had fallen and the Turkish power was established near the frontiers of Hungary. On the west, the country's neighbours were looking with a jealous eye upon the growing power of King Matthias. The Gernan Emperor Frederick and the Polish king considered themselves entitled to the Hungarian throne.

Matthias was of such stuff as conquerors are made of. His proud and warlike spirit would brook no offence. Every victory fed his vast ambitions and pointed out new aims. He had perfect confidence in himself and in the strength of the nation and resolved to rule not only in the east but also in the more civilised west. He was not merely prepared to meet conflicts which were inevitable, but himself commenced such as could easily have been avoided. As a result, Hungary was surrounded by foes and needed military strength more than ever before.

Here the great difference in the situation of England and Hungary made itself felt. Hungary had avoided a civil war like that which in England had crushed the power of the nobility and had rendered the task of the Tudors easy, yet in consequence of her geographical position it was far more necessary for Hungary than for England that her monarch should be supreme.

At this crisis the instinct of self-preservation did not 
forsake the Hungarians. They saw where their interest lay, and the accession of Matthias to the throne marked the victory of that policy which had so often enabled the nation to struggle manfully against great odds. Hungary may have been guilty of many faults but she never made the mistake of forgetting how essential was the strong hand of the ruler to her welfare. It was the recognition of this fact which had given power to the hand of John Hunyadi, had paved the way for Ladislas V. and which now proved the strong support of King Matthias. The nation looked to him to restore internal peace and unity, and in his dealings with outside powers, to complete the work of his immortal father. Mathias, like the Tudors, had to stop the process of disintegration which had set in as a result of the decay of the royal power, but his task was much more difficult than theirs. The English needed no new prerogatives or new instruments in order to establish order, but the Hungarian ling had to acquire the necessary power.

It was fortunate that the question of power began at that period to shape itself favourably to monarchs. Standing armies were being created which possessed great advantages over a merely armed crowd; cannon were coming into use, while a general and increasing desire for peace was smoothing the way for absolutism.

On the one hand was the problem whether Hungary could withstand the attacks of her external foes and whether the process of disintegration within could be stopped, while on the other hand there was the question whether the king of Hungary would not make use of the circumstances in his favour against the constitution. Was it possible for the king to strike the happy mean, and while putting an end to freedom's exaggerations, which were threatening the country with disruption, still to respect its just bounds? In England, where to trust the king with a large standing army would have jeopardised the country's freedom, the political situation with respect to foreign nations did not demand that the monarch 


\section{DEVELOPMENT OF HUNGARIAN LIBERT'.}

should possess any considerable military force, but in Hungary the nation's vital interests demanded that the king should have control of rast forces.

How did Matthias act in this critical situation? His keen eye saw far and clearly, and his gaze was ever directed to the nation's interests. He never tried to gain absolute power but always strove to serve his country.

One of the chief points of his policy was to reserve as much of the nation's strength as possible for operations beyond the frontier of Hungary, and he endearoured to organise the community accordingly. Let every man be strong and able to fight but let him spend his strength in discharge of his duty to the state. Let the ling be supreme over an armed nation, not in order to weaken his former rivals but to direct their efforts into a proper channel.

It was the king's task to see that the rivalry of the different sections of the community did not paralyse the state, and that every particle of the country's strength should serve the nation's interests.

His strong will, his proud self-reliance, and the habits of warlike times, no duubt awakened autocratic inclinations in Matthias. He wished his great abilities to be able to work unchecked by the petty interference of others. Whas there ever a gruat man who did not feel as a fetter on his genius the necessity of winning the adhesion of small minds and selfish hearts to his schemes? Moreover, Matthias was a contemporary of Louis XI., Ferdinand the Catholic, and Iran III. Like them he desired power. He saw only too clearly how dangerous to the nation was any weakness at its centre. It was an absolute duty to restore the dignity of the monarchy, and we can well understand that he should lay great stress upon his rights. The great nobles, too, looked upon him as an upstart and pricked him with their disdain. This must have wounded his proud and ambitious seul and he therefore resolved to be feared and obeyed everywere.

Yet it remains true that the king did not aim at abso- 
lutism. His sound practical sense overcame any inclination in that direction. He controlled his autocratic tendencies directly he saw that they would absorb all his strength and interfere with his foreign policy. His sane judgment discerned the point to which he might go on the path of autocracy, and where he must comply with the requirements of liberty. He understood that from a nation like the Hungarians, more was to be gained by respecting their rights and using gentle methods, than by some new system of government which must inevitably arouse antipathy or by commands and compulsion. He saw, too, that if he was to play an important part in European politics he needed the support of the great nobles, and accordingly he had no desire to weaken them. He made magnates of many of his faithful adherents. Szapolyai, Kinizsi and others, owed to him their great wealth and high rank. He also maintained the power of the old noble families. He pardoned even his most dangerous adversaries, such as Garai, Ujlaki, Szilágyi, and Vitéz, when he thought that by so doing he could win them over. His aim was to make the nobles faithful to him, and he only punished the defiant oligarchs and robber knights. Whenever he could he avoided violence, and even spared Giskra, the infamous Bohemian robber knight, and took him into his service. An incident which occurred in the year 1471 was typical of his methods. Archbishop Vitéz was guilty of forming a conspiracy in favour of the king of Poland. Mathias pretended to know nothing of the conspiracy, treated his enemies in the most friendly way, made them grants of land, and chose them as leaders in an expedition against the Polish king. Of course, if the men had not feared him, had they not known well enough what an iron hand was beneath the velvet glove, this policy would not have succeeded.

Had the king been aiming at absolutism his actions would have been very different. I tyrant sees a culprit even in an innocent man and does all in his power to remove from his path anyone who is likely to be danger- 


\section{DEVELOPMENT OF HUNGARIAN LIBERTY.}

ous, but he who builds a golden bridge over which the unfaithful may return to him, is evidently guided by other mutives than a desire for absolute power.

When in 1459 Matthias came into collision with the Limperor Frederick, he assembled the leading nobles and asked them whether they really wished that Frederick should be their king, because if so, he was ready, for the welfare of the country, to abdicate in his favour.

The loyalty which he could demand as a right, he bargained for with the promise that he would never alter the existing laws without the nobles' consent.

He sought the adrice of the magnates on the most important subjects and never resented a sincere word.

If necessary, however, Mathias could smite erring nobles with an iron hand. They must respect the nation's laws and be ready to make sacrifices for king and country or he would crush even the mightiest of them. He humbled even his own uncle and benefactor, the powerful and popular Szilagyi. He bestowed wealth and rank lavishly, but the recipient must use the gifts for the benefit of the country or let him beware. The sentence introduced by him into the Hungarian code in 1486 : " Those who abuse the favours and prerogatives granted to them shall justly be deprived of the same " was no idle word but represented a fundamental principle of his action. With him, right and duty, prosperity and sacrifice, went hand in hand.

But could his policy lead to the desired results? His power was limited owing to the circumstance that his throne was surrounded by nobles possessing immense wealth, strong fortresses and numerous troops. With their ancient dignity, they preserved their old ambitions. As Matthias himself had sprung from the ranks of the gentry they could not regard the crown as something beyond their reach. The friendship of powerful nobles like Szapolyai and Bathori was sought after by the monarchs of other countries.

Such subjects could not be slighted even by- Matthias himself, especially as he needed their assistance for his 


\section{ROYAL REACTION IN HUNGARY.}

foreign schemes. Yet he was able to keep them in proper subjection. He listened to their words, but it was always he who decided.

Matthias remained true to his policy in his dealings with the gentry. He desired to bind them to himself and to use their strength in the service of the country, but without depriving them of any of their rights. They were easier to handle than the magnates. Some of the magnates saw their enemy in the king, for they knew he had been elected to counteract their influence, but the gentry were his partner in interests. They had taken to heart the lesson of recent times, that weakness of the ruler meant civil war, and they therefore desired a strong ling, but they were not moved by fear to place internal peace so far above every other consideration as to be willing to sacrifice all else for that. They were ready to be the king's allies but not his tools. They overlooked an occasional breach of the law, but clung to the constitution. The attitude of the Hungarian gentry towards Matthias was different from that of the English gentry before the advent of the Tudors. In Hungary it was the gentry who, after the death of John Hunyadi, the father of Mathias, defended the nation's interests most faithfully, and it was they who saved the state from anarchy by electing Matthias as king.

They took this step not only because they looked for the restoration of order from him, but because he was one of their own class and they hoped he would serve their interests. But the question was whether the many rights of the gentry would not restrict the power of the king.

Their first act showed that the old spirit was not dead in them. Although Matthias was already seventeen years of age they appointed Szilágyi, his uncle, regent for five years, and they passed laws which considerably lessened the royal power. In place of the established custom they made it compulsory that the nobles should attend Parliament in person at its annual meetings, a measure which sowed the seeds of disorganisation. Such a crowd could 


\section{DEVELOPMENT OF HUNGARIAN LIBERTY.}

not remain together long enough to get to understand important and difficult questions. Serious debate and the formation of just opinions were equally impossible. Suddenly, without any preparation, inexperienced men were called upon to decide matters which even the most expert could only settle after much deliberation. Such a crowd must either become the tool of power behind the scenes, or else bring the state into a condition of anarchy.

The same law condemned the king to impotence, for while it declared that he was to defend the country by means of his own forces, and if they proved insufficient, was to apply to the nation, yet it prohibited him from demanding any taxes.

Difficult as the situation was, Matthias saw what he had to do. Surrounded as he was by magnates, mostly hostile to himself, and by a gentry class, loyal but exacting, accustomed to liberty and inexperienced in the great affairs of State, he recognised it as his best policy to restrict his ambitions. First of all he endearoured to satisfy the reasonable demands of the gentry. That was his aim when he destroyed the nests of the robber-barons and gave back stolen lands to their rightful owners, and when he regulated the tolls. He was the first king for a long time who had dared to punish powerful wrong-doers. Matthias could influence the gentry as no one else could. His popularity was greater than that of Louis the Great. That king was the idol of the great nobles. $\mathrm{He}$ created a high order of nobility and became the pattern of the country's warriors, but the gentry class, influenced by the old national spirit, could hardly feel so entirely one with him as with Matthias. In Mathias, every Hungarian, and especially every member of the gentry, saw the type of his own class. His successes were their glory, and he shed a radiance upon the class from which he had sprung.

To the inherited popularity of his name, and to his undaunted valour, was added the advantage of being able to captivate the imagination of the crowds better than any- 


\section{ROYAL REACTION IN HUNGARY.}

one else. There have been few kings who could so readily' as he find a way to the hearts of vast masses of their subjects. Concessions which he was obliged to make he granted in such a way and at such a time as gave them the appearance of being voluntary, and created a feeling of gratitude. He was equally downright in showing generosity and severity. When Simon Nagy suffered a defeat, the army trembled in anticipation of the king's anger and of the punishments he might inflict, but the king consoled instead of upbraiding them, and when the occasion arose he sent them to war again under the same leader. They repaid his trust by superhuman efforts which brought victory. In rewarding he was most liberal, and being strong he could be forgiving, as no one could mistake his leniency for weakness.

On the other hand, if he desired to convey a lesson by punishment, he did not shrink from making an example of the highest in the land. After the imprisonment of his own uncle, who would dare defy the king? The smaller men saw with mingled fear and satisfaction that the king dared to punish even the greatest.

The fabulous splendour of the court of Matthias, and his artistic taste, increased his greatness in the eyes of the people. On the other hand, they were fascinated by the thought that the king often mingled with them in disguise. He whom to-day they saw as a peasant among the humblest people, appeared to-morrow in royal purple surrounded with all the pomp of a great monarch.

Matthias not only really was a great man, but he also knew how to make others perceive it, and appearances carry more weight with most people than facts. He was cut out for the idol of a people, and the hero of tales and poems. Hungary never had another king of whom the people would tell such fascinating tales as were told of him whom they called "the Just."

The king linew, however, that in spite of all the love felt for him by the middle classes, it would be impossible to count upon them unless he respected their rights and 


\section{DEVELOPMENT OF HUNGARIAN LIBERTY.}

gave them an active part in the work of government. They would have fallen out even with him had he attempted absolutism, but he valued their loyalty more than his own personal advantage.

In home policy Matthias refrained from risky enterprises in order to reserve undivided strength for his foreign policy. The Diet was frequently convened. The king tried to persuade instead of commanding. $\mathrm{He}$ listened patiently to the objections of the middle classes and suffered their most severe criticism, promised the alterations they demanded, redressed grievances and confirmed the constitution.

His methods could not fail to lead to important results. The Diet usually fell in with his plans, and he associated personally with the nobles and won their constant support. He was able to keep the powerful nobles well in hand, because the bulk of the nation followed him rather than them. Since the time of the Angevins the magnates had led the gentry and the secret of their enormous influence was their backing by the nation.

But when, during the reigns of Albert, Wladislar. and Ladislas $\mathrm{V}$., the unruliness of the great nobles passed all bound, the middle classes instinctively sought for a new leader. Ladislas $V$. had not intelligence enough to see that in this turn of events fate had placed a trump card in his hands, but Matthias at once seized the opportunity of restoring the ancient alliance of king and gentry.

A similar transformation of the whole situation occurred with respect to military service. Just as the nation had voluntarily voted more taxes than ever before, so it cheerfully took upon its shoulders a heavier burden in the shape of military duties than it had previously borne. It was to this readiness on the part of the nation to make great sacrifices that Matthias owed his success, and it was on that account that the king did not attempt to alter the system of government. By acting in this 
way he awakened love and loyalty and still gained all that he desired.

One institution, however, the king needed to give effectiveness to his will, and that was a standing army. When gunpowder came into use the professional soldier gained a decisive advantage over the non-professional. So long as arrows, swords, and lances were the principal weapons, and while the cavalry formed the bulk of the army, the Hungarian gentry were the best soldiers possible, for they were familiar with horses from their childhood, but they did not understand the handling of cannon and muskets, and they were not willing to serve as infantry at all. Success in battle came to depend more and more upon the careful training of soldiers and cleverness of tactics, and less upon personal valour. Matthias, one of the greatest generals of his age, could not have done what he did without a well-organised and carefully trained standing army. The victory of the cause of freedom in England, amid the crises of the sixteenth century. was largely due to the circumstance that the nation, whose situation did not render a standing army necessary, could easily thwart the king's efforts to create one, as it was only too manifest that he required it for the purpose of coercing his subjects.

In Hungary, the superiority of the community orer the king in respect to military strength, had hitherto been the chief support of the constitution. What then would happen if this position were reversed, if the king's army were all powerful, if his cannon on the hilltops could batter the hitherto impregnable fortresses, and if there were not one corner of the country which the avenging hand of the king could not reach?

Would the constitution, based as it was upon the right of armed resistance, crumble to pieces when resistance was no longer possible?

The danger was very real, yet during the reign of Matthias, circumstances enabled the country to steer clear of it. The "black army" of Matthias was not so 
strong as to enable the king, while prosecuting his wars outside the country, at the same tine to establish at home a government founded upon violence, for on Hungarian soil violence alone could establish absolutisn. The king's army was not in itself sufficient even to meet the requirements of the foreign wars. Matthias could not have successfully conducted these wars and defended his country from invasion, without the help of the soldiers of the great nobles and of the whole nation in arms. Had he endeavoured to use his standing army for violent revolutions at home, he would have become impotent abroad and have defeated his whole policy. So long as he was dependent upon the nation's help and goodwill, the right of resistance was still an effective weapon against the king. If, however, it had been the only weapon, sooner or later the king, with his standing army, could easily have broken its point and overthrown the constitution. The day would come when foreign wars were ended, and the troops hitherto employed abroad, would be set free for use at home, and then the king might devote his undivided power to the task of strengthening his own position. That is what happened in France. Charles VII. organized a large army to fight the English, but when the war with England was over, his successor, Louis XI., employed those soldiers in crushing his opponents at home.

But the great expense of a standing army furnished another weapon for use against aggression, and the nation, guided by a sure political instinct, made a wise use of this means and saw to it that the power which was so necessaly to the king should at the same time serve the interests of the country. In this lies one great difference between the history of France and that of Hungarv.

France, disintegrated by feudalism, had not strength enougl to oppose the king, reinforced as he was by his standing army, but in Hungary events took the same turn as they had done long before in England, and as a result of the same public spirit. The situation of Mat- 


\section{ROYAL REACTION IN HUNGARY.}

thias was exactly the same as that of Edward 1. and Edward III., and the similar situation led to similar consequences. We have seen that in England the kings were unable to meet the expense of their wars from their own treasury and were driven to find new sources of income, if possible, without the necessity of obtaining the nation's consent. As this, however, was not possible, they were forced to apply to Parliament, which imposed the condition that no tares should be levied without its consent. The monarch continued to struggle against this state of affairs but without much success. The leading classes of the nation were sufficiently strong and skilful to see to it that the king should obtain money through them alone.

A considerable time later, events took a similar course in Hungary. Matthias found himself, after some time, unable to cover the expense of his military operations, partly because wars were becoming more costly and partly because the standing income of the monarch had been diminishing. Large estates belonging to the crown had been given away, and the income derived from tolls had considerably decreased by reason of the exemptions extorted by the nobles, and which extended in some measure to their dependants. Matthias had to increase his revenue somehow. He relieved some of the counties of the necessity of holding their very expensive meetings in consideration of certain money payments. He demanded a certain amount of free labour from the people for the building of fortresses and the provision of food for the soldiers. Some of the great nobles were obliged to grant loans. In order to maintain the fortresses the king imposed taxes on those who lived in their vicinity. He ignored immunities from taxation, and compelled the nation to contribute either in money or in kind to the upkeep of his armies.

But all these shifts availed little, and Matthias was obliged to get the nation to agree to new taxes.

Until that time, new taxes were very rarely necessary 


\section{DEVELOPMENT OF HUNGARIAN LIBERTY.}

and there was no clearly established rule as to who had the right to impose them. Robert Charles gave offence to some by levying a tax after having discussed its necessity with the barons. Louis the Great, seeing that the nation had not approved of his father's methods, endeavoured to settle the matter by law. During the Turkish wars, extraordinary taxes had been imposed in many different ways. Sigismund often levied a tax in a thoroughly autocratic manner. In his absence abroad, the royal council decided the question of taxation.

In Albert's reign, some of the great nobles gathered together in the camp at Titel and proclaimed a tax on their own authority, declaring that they would use force if anyone neglected to comply with their demands. In most cases, bowever, the Diet had roted the taxes although there was no law necessitating the nation's consent.

If matters had gone as the Estates wished, the question would not have been settled during the reign of Matthias. They objected strongly to being taxed at all. A law of Ladislas $V$. had declared that extraordinary taxes were not to be imposed in any way or under any title, and after the election of Matthias it was again proclaimed that neither king nor governor had any right to tax the inhabitants of the country. In 1458 it was enacted that the ling should "not impose the tax of a florin or half-a-florin, which his predecessors had demanded from time to time, even in the most difficult circumstances." When in 1462 the king demanded the imposition of a tax, the Estates made him promise that it should not be repeated. As time went on, however, neither king nor the Estates could oppose the force of circumstances. Money was urgently needed and the Estates saw that as taxation was inevitable, they could best defend their interests by making their consent an indispensable condition of taxation. The laws passed between 1468 and 1471 all tend in this direction, and Matthias had to accept the principle. 


\section{ROYAL REACTION IN HUNGARY.}

The authority of the Diet was great enough to prevent Matthias from acting as the French monarchs acted, and he, like the English kings, came under the control of the Estates through his need of money.

Naturally Matthias tried to evade the law by roundabout ways of obtaining money, but he could never obtain enough by such means, and whenever he was driven to appeal to the nation, care was taken to put a stop to any irregular methods. It was declared that the ling could not demand any free labour or provisions for himself or his army, or for the building of fortresses. Autocratic methods of raising money were forbidden, amongst others, the compulsory purchase of salt, which was a state monopoly.

We see, then, that even a standing army could not free Matthias from the necessity of maintaining friendly relations with the influential sections of the community. It increased his power and enabled him to put down some rebellious noble, but it did not enable him to emancipate himself from the influence of the Estates. Time had so strengthened the constitution that Matthias had to adapt his policy to it.

It was one of the most valuable achievements of the past that the king found his interest lay in respecting the liberties of his people, and it gives proof of the wisdom of Matthias that although not altogether free from the despotic notions of his time, and, perhaps, inclined by temperament to autocratic methods, he yet sought to gain power not by any tampering with the constitution but by winning the nation's love and esteem.

The king was entirely successful in his aims. The chaos which had been caused by the unbridled ambitions of the great nobles, save place to order. One will was supreme throughout the land, and law ceased to be a dead letter. Yet the cause of liberty did not suffer. On the contrary, new bulwarks were raised for its defence. The royal power in Hungary did not owe its strength to 
the weakness of other elements of the nation, as happened in England under the Tudors.

The legal achievements of Matthias may be divided into two classes. Some were calculated to please the Estates, while others were designed to organise the nation in a more practical way.

Among the first class, the most important was that which gave the Estates the right to vote or refuse taxes. This was a fundamental right which led to many others. Personal liberty was defended by the law that no one should be punished for treason without the concurrence of the barons and prelates. No one's land was to be taken, even by the king, except by lawful process. Noblemen could not be imprisoned save after lawful trial. The king could not dispute the validity of any judgment lawfully passed, and no noble could be exiled until the matter had been brought before a council composed of prelates, barons and gentry.

All this tended to secure the individual's person and fortune from tyrannical action on the part of the monarch.

Naturally, Mathias frequently infringed these laws, but we must not measure the past by the standard of the present. In the Middle Ages every ruler broke the laws. Respect for legal rights was not yet fully developed.

Matthias frequently took the law into his own hands in dealing with his adversaries, yet he was always ready to pacify the people with new laws and promises, so that the nation not only defended its liberties but increased them.

It was of great importance in its influence upon legal development that the king frequently convened the Diet. The want of money made it necessary that the Estates should be convened as often as possible. As early as the time of the Krpáds the kings were compelled by law to hold a "law-giving day" every year, yet the rule was not very faithfully observed until circumstances rendered 


\section{ROYAL REACTION IN HUNGARY.}

it absolutely necessary, but as soon as the same reasons operated in Hungary as in England, to make the national assembly important, similar consequences followed. Matthias summoned the Estates so often that attendance became a heavy burden. In 1471 a law was passed that the Diet should be convened annually only if it were absolutely necessary. Some historians see in this law a subtle effort on the part of the king to emancipate himself from the control of law. Yet if we consider that in other details of the same law Matthias set himself to gratify the wishes of the Estates, his crown being at that time threatened with the gravest dangers, and if we compare the law with that of the following year, we are driven to the conclusion that the proviso must have been demanded by the Estates.

In 1472 it was enacted that "as the frequent meetings of the Diet are a great burden upon the country, there shall be no meeting for two years from this date."

In spite of these laws, however, the king found himself compelled to convene the Diet frequently, and this had important consequences, for it enabled the nation to obtain speedy redress of grievances. It also familiarised the Estates with politics, for the king had to give an outline of his plans in order to obtain money. One law directed that the taxes voted were only to be used for fighting the Turks, and the Diet thus gained a voice in international politics. The most exalted prerogative of the king, that of carrying on war, came under its influence.

It was in 1462 that a law was passed that "every matter which affects the general welfare of the country must be discussed and decided in the council of the nation."

Matthias did not always respect this principle, for it often happened that he contravened what had been decided by the Diet. For example the law obliged every noble, under penalty, to attend Parliament, yet the king never exacted the penalty from those who absented themselves. It was forbidden by law to exempt anyone from 


\section{DEVELOPMENT OF HUNGARIAN LIBERTY.}

the taxes imposed by Parliament, but Matthias exempted Andrew Paumkirchen. These, however, were exceptional acts, due to the necessities of the case, and did not alter the fact that the king accepted the principle that whatever affected the nation should be decided with the concurrence of the nation.

In the sphere of administration no radical changes were made during the reign of Matthias. The Estates found that the king would not act as their tool. His first Diet conferred upon him the right of filling the various offices under the state upon his own authority; it was only decreed that foreigners should be excluded from all such posts. The king was allowed to dispose freely of the office of Palatine, which he bestowed upon Országh after dismissing Garai.

Towards the end of his reign Matthias widened the Palatine's sphere of activity and himself proposed that in future the office should be filled by election. He knew well enough that the man of his own choice would win the election, so his influence would not diminish, while he would be flattering the nation by keeping to the form of the law. His great desire was that after his death, his illegitimate son should succeed him, and he knew that this result could best be brought about by the help of a Palatine who had been chosen by the nobles and accordingly possessed their confidence, and at the same time was devoted to Matthias.

In 1471 it was enacted that if the king issued any order inconsistent with the law, the order was to be ignored. If, however, the officials themselves were guilty of any breach of the law, they were to be summoned to the royal courts and punished, and it was no sufficient plea that they had acted upon the king's orders. The law entitled the officials "the defenders of the administration," and the expression conveys a just idea of their vocation. It was their task to see that the laws were executed, and it was their right and also their duty to punish any subject who infringed them. Should unlaw- 


\section{ROYAL REACTION IN HUNGARY.}

ful commands proceed from one above them in rank, it then became their duty to refuse to execute them.

The question remains whether the executive could meet these demands. Judicial impartiality was not very much in evidence. The royal courts, which stood at the head of the administration, did not guarantee the supremacy of justice. Nor did the great figures in politics, such as the Palatine and county-lieutenants, give unbiassed judgments, and their adversaries could hardly count on equity. But this was not expected of them. What was expected was that they should defend the rights of their class and in that respect the nobles might safely trust them. Those officials were men of an independent spirit. It is true that their appointments were subject to the king's pleasure, yet their immense wealth, their social standing and political ambitions, made them worthy defenders of their order, as they were strong enough even to defy the king. They often gave more glory to their office than they received from it. Their duties were often dangerous and they had occasionally to risk their lives. Their posts were desired not for the sake of the salary attached to them, for they frequently entailed considerable pecuniary sacrifice, but for the political influence which they gave. Appointment to such posts was rather an acknowledgment of a man's power than the basis of it.

'The law of 1471 was exceedingly important. It established in the realm of administration the same principle that governed legislation, namely that the joint will of king and nation was more valid than the sole will of the monarch. Even if this principle was not always adhered to, it was a great step in advance that at so early a period a serious effort was made to establish the supremacy of law, and that any despotic actions, even on the part of the king, should be declared unlawful and deserving of punishment.

As we have said, Matthias desired to please the people by confirming their liberties, yet he never lost 


\section{DEVELOPMENT OF HUNGARIAN LIBERTY.}

sight of his final aim of organising the nation in such a way as to qualify it for efficient action abroad and for healthy and harmonious life at home. He lnew that his reign could only prove of lasting benefit to the country if he could so improve and strengthen its institutions as to secure that law and order should prevail.

One great fault in the old system was the exemption of the nobles and their dependants from taxation. At a time when the taxes furnished but a small fraction of the income of the State, this privilege entailed no very serious consequences, but during the reign of Matthias it meant very great loss to the Treasury. Government cannot be carried on without money, and a scanty revenue entails feebleness in the State. Matthias therefore, in 1467, began to widen the sphere of incidence of the taxes, Certain dues which had been customary since the Angevin period were abolished, as their value had greatly diminished owing to the many exemptions which had been granted. In their place a new tax was imposed, from which the smaller landowners and the tenants or dependants of the nobles were not exempt. The Seklers, Saxons, Jazigians, and Cumanians, who had shared the privileges of the gentry, also had to pay the new tax.

The king adopted a similar policy in dealing with the tolls. He introduced the "royal toll" which had to be paid by all except the nobles, and which in that respect was quite different from the old "one-thirtieth" toll.

It is true that the principle of universal taxation was not established in so many words, yet as the taxes paid by the nobles' tenants and dependants were really borne by the nobles themselves, the new system practically spread the burden of taxation over the whole community. No new principle was expressed, yet the tax fund was largely augmented through the restriction of ancient privileges within narrower limits, and a decided step was taken towards remedying the chief evil in the constitution.

Naturally, the privileged classes fought vigorously 


\section{ROYAL REACTION IN HUNGARY.}

against the innovation, which caused widespread dissatisfaction and even open revolt, and in 1468 Mathias had to exempt a number of the smaller landowners from payment of the tax.

The king endeavoured, by means of his war taxes, to accustom the nation to the idea of universal taxation, and occasionally he succeeded in making the nobles pay taxes, but it remained the rule that only their tenants should pay.

In the case of the expenses connected with local administration in the counties, the king was more successful, compelling everyone to bear a share.

Condemnation of the system of taxation is to be met with in a law which declares that " in consequence of the exemption of the great, unfair burdens fall upon the gentry, especially the poorer among them."

The privileged classes had remained immune from taxation because the Arpád kings had not needed their money; and the reason why Matthias partly failed where the English kings, in very similar circumstances, succeeded, is that centuries of immunity had generated in the minds of the nobles the notion that the payment of a tax was a humiliation and a mark of servitude.

Matthias succeeded better with the so-called "blood tax," or compulsory military service. He almost doubled the number of soldiers which landowners had to provide in proportion to their holding. The banderia or regiments formed in this way had to serve for three months, and if necessary, were to serve abroad.

The rest of the military forces of the community could only be compelled to serve within the borders of Hungary, but on the other hand their term of service was not limited. It was to be regretted that Matthias did not give a powerful organisation to these forces or inspire them enough with the military spirit. In his foreign wars and for the occupation of conquered territories, he relied upon regular paid armies, and the latent military capacities of the community were not developed as much as was desirable and 


\section{DEVELOPMENT OF HUNGARIAN LIBERTY.}

the bulk of the people did not learn so much in the school of their great leader as they would if they had been led against the Turks.

Matthias did very much in the way of compelling the influential classes to take upon their shoulders a fair share of the work of administration. Sigismund's law was revived, and any member of the noble class who was asked to accept the post of "szolgabiro" (a kind of sheriff) had to do so or incur certain penalties. Matthias ordered every county to elect annually eight or twelve nobles who were to hear lawsuits, examine witnesses, enrol soldiers and to see that judgments were properly executed.

The inhabitants of the counties were obliged to take up arms against transgressors of the law if the county lieutenant or his deputy desired it. Members of the privileged classes were expected to be ready to sacrifice their wealth and their lives in the service of the state, as well as to give their labour. What to-day is done by the police or gendarmerie, was then done by the nobles.

Matthias took care that the administration should not be subject to the pleasure of the public, and that its officials should be able to perform their duties without fear or partiality, even though they were opposed by powerful interests. Only wealthy men were appointed, so that there might be no danger of bribery. To protect the independence of the officials, only posts to which no salary was attached were made elective.

Those elected were obliged to serve. Their post was a burden and not a favour, so that they were not likely to act with partiality in order to win the suffrages of the public.

The office of "ispán" (county lieutenant) had no regular salary attached to it, but the political influence which it gave, together with the fines which fell to the lieutenant's share, and in some counties, the landed property which went with the post, made it so desirable in the eyes of many that had it been elective, they might have been willing to sacrifice their independence to their 


\section{ROYAL REACTION IN HUNGARY.}

ambitions. The king accordingly retained in his own hands the right of nominating to that post, and the lieutenant appointed the deputy lieutenant.

The officials' independence of the public was not in itself enough to guarantee that the interests of the state should be properly served. The county lieutenant was generally a very influential man whom it was difficult to control. The absence of salary in the case of the subordinate posts made their holders independent in their attitude towards those above them as well as those beneath them. The central government might easily have lost control over its instruments had it not taken steps to guard against this danger.

Matthias increased and regulated the functions of the magistrates. Anyone opposing the lieutenant or deputy lieutenant in the execution of their duties, was guilty of treason. The utterance of any slander against the judges of the law courts entailed severe punishment.

It was made the duty of the nobles to execute the judgments of the courts. The work of the officials and of the courts of justice increased considerably, because the community became more and more regulated by laws, and as culture spread the. interference of the state in dofence of rights became increasingly necessary.

The power of the magistrates received a great accession also from a law abolishing the privileges granted in olden times, which rendered certain noble families directly accountable only to the king, and subjecting everyone, the county lieutenants only excepted, to the legal authorities of the counties.

This important reform, establishing equality before the law, at once increased the work and the influence of the administration, but the reins of that administration, now become so powerful, must be firmly held by the king. If the control from above is not effective, officials may easily use their power for selfish purposes, and if to the influence of their office is added that of great wealth and 
social standing, the danger of their becoming autocrats within their respective territories is very great.

Matthias dealt with this problem by means of some very severe laws. These emphasise the rights of the king and his council as against the various officials. Should their indolence or negligence involve the state in any loss they could be compelled to make good the loss. They were liable to various penalties, and every one of them, including even the Palatine, could be dismissed from his post, while any judgment of theirs could be appealed against to the king.

It was in order to counteract the overwhelming influence of the county lieutenants that the king increased the privileges of the county nobles. When new laws were passed, it was to the nobles of the counties that they were sent for proclamation, and as will be seen, the Parliamentary representative was elected by the same classes.

It was very important from an educational point of view that the counties had to bear their own administration expenses. Conscientious management, economy, and a just sense of responsibility can only be learnt by those who have to find the money which they spend.

The autonomy of the local councils inaugurated by Matthias is an achievement of which his country may be proud. It was based upon the same principle as the autonomy to be found in England, which had been so much admired by the whole of Europe.

That autonomy has been the bulwark of freedom, because the social and financial standing of the local officials, and the honorary character of many of their posts, have guaranteed an attitude of independence towards the higher powers.

In both countries the system of administration has been so devised that the governing bodies have shared the interests and sentiments of the nation, and it would have been difficult to use them against the nation with which they were so entirely one. They have taught respect for the state and for law even to the most powerful 


\section{ROYAL REACTION IN HUNGARY.}

sections of the community, and they have been able to discharge their duties and give effect to the king's will, because they were largely independent of the goodwill of the community and were subject to central control.

The administrative system of Hungary had one advantage over the English system, in that it gave to the intelligent classes of every county an exceedingly efficient organisation in which they could find scope for their administrative abilities. In local government, as in the government of the state, there are some matters which can be settled better by large bodies than by individuals, and which require the co-operation of all those whose interests are affected.

On the other hand there are many matters which can be best dealt with by individuals. In England, the officials tended more and more to throw into the background the councils, until these ultimately disappeared. In spite of the English theory that the taxes must be voted by those who pay them, rates or local taxes were imposed by officials, while in Hungary, this awkward situation was aroided, and the county organisation remained. During the reign of Matthias, the two complementary elements of the administration were in happy equilibrium. In later times the autonomous elements in the counties gained the upper hand, and there ceased to be uniformity in administration over the whole country.

As soon as this element became a means of resistance to central control it ceased to be efficient as a means for securing public order.

We have now glanced at the achievements of Matthias in the domain of public rights, and have seen that they united the nation beneath the strong hand of the ruler and yet confirmed the people's liberties. The king could not prove equal to the great tasks confronting him unless he was in perfect harmony with an independent community. He was therefore compelled to respect the rights to which the nation clung. He removed many inequalities between the various classes, and made their co-operation 


\section{DEVELOPAIENT OF HUNGARIAN LIBERTY.}

possible. He forced the intellectual elements of the nation into the service of the state and developed their political ability.

The task assigned to Matthias was that of strengthening the weakened edifice of the state. His policy was sound, but his life was not sufficiently long to allow of his achieving all his aims. 
THE JAGELLO DYNASTY.

\title{
CHAPTER XIII
}

\author{
THE JAGELLO DYNASTY.
}

\section{STRUGGES BETWEEN NOBLES AND GENTRY. KING IVLADISLAV II.}

Unfortunately the reign of Matthias, though it was the most brilliant page of Hungary's history, could not transform the state into a new organisation, and the times which followed were not favourable to progress along the lines laid down by that great king. Mathias undoubtedly accomplished much, but he was unable to achieve that most difficult of all aims, that of perfecting an organisation which could be an adequate substitute for his own great qualities, and could enable the state to steer clear of danger even when guided by a smaller personality. It was inevitable in that age that Hungary's fate should depend very largely upon the kind of ruler she had. A great king could urge the nation to extraordinary efforts, while a weak personality meant disaster. It was not easy for a successor to take up the work of the late king. To do so demanded a personality as great as his. Matthias had not entirely averted the dangers threatening from abroad, in fact he did not in that respect do as much as he might have done. Probably he had more brilliant qualities than his father, John Hunyadi. His resolution was firmer, he was perhaps a more skilful diplomatist and had a wider horizon, yet he was not so great a man. The way in which he gathered the strength of the nation into his hands reveals a tenacity of purpose only found in men of the strongest character. He never lost sight of his aims 


\section{DEVELOPMENT OF HUNGARIAN LIBERTY.}

and subordinated to them his own feelings. But when he had acquired the power he did not display his father's greatness in the use he made of it. As in the case of so many others, the consciousness of power created within him the desire to shine and gain renown, without giving sufficient thought to the lasting benefit of the nation. Many great men have shown a desire to render their names immortal by brilliant deeds, even if such deeds were not demanded by the country's welfare, and whenever this feature has manifested itself in a man, it has usually lessened the value of his life to mankind. John Hunyadi never yielded to any such impulses. He never attempted anything which the prosecution of his great aim did not necessitate. All his efforts were directed to the averting of the danger threatened to Hungary by the Turks, and neither desire of glory nor of revenge could make him deviate from his chosen path. Had Matthias acted similarly, the country might have escaped the disastrous defeat at Mohács (1526) and the struggle between the two neighbours might have had a different issue. Many of his contemporaries thought that Matthias was losing a good opportunity. His councillors openly expressed the opinion that in order to gratify his vanity and in defence of comparatively small interests, he squandered money and energy when the very future of the country was at stake. The wars against Bohemia and Austria were so unpopular that the nation generally voted taxes only for the Turkish wars. The whole of Christendom recognised the fact that Hungary was its bulwark against the Turk, and it was the common opinion that in defence of western culture and religion Hungary's great rocation was to stem the tide of Turkish invasion.

In spite of this, Matthias did not pay sufficient attention to eastern matters. He missed the last chance of successfully terminating the great struggle. Even when Hungary was powerful she contented herself with remain- 


\section{THE JAGELLO DYNASTY.}

ing on the defensive, so the Turks chose always the most favourable moment to attack. The result was that in spite of the glorious reign of Matthias, at its close the Turkish peril had not diminished.

The internal affairs of the country at the time of Matthias' death demanded a successor as able as himself. In the absence of his strong personality his system lost much of its efficiency and freedom degenerated into disorder. Matthias was satisfied with being able to coerce the great nobles into acting loyally, but what if a weak ruler should succeed him? The middle classes clung tenaciously to their rights. Matthias avoided all disputes with them and was content with his ability to persuade them to make sacrifices for the good of the country. But what would happen if his successor lacked his fascination? The matter of the standing army bristled with problems.

To Matthias the nation had roted money for maintaining an army, but it was doubtful if it would do as much for his successor. What was to happen if a commonplace personality, unsupported by an army, should stand opposed to powerful sections of the community which aimed at establishing either an oligarchical or democratic régime? And fate was not kind to Hungary in the matter of successors to the great king. Matthias died without lawful issue and the nation had to choose a king. Its choice was an unfortunate one, and Hungary feels to this day the evil consequences of the step then taken. Perhaps the great successes of Matthias had diminished the nation's consciousness of impending danger. The Hungarians are unfortunately apt to be optimistic, and lose their heads more easily in prosperity than in adversity. They thought they could do without a strong king, so of all possible solutions to the problem confronting them, they chose the worst, selfishly thinking that a weak and commonplace king would be the safest for themselves. They might have elected John Corvinus, the illegitimate son of Matthias, or Maximilian of Habsburg, and either 


\section{DEVELOPMENT OF HUNGARIAN LIBERTY.}

of them would have been immensely superior to the unfortunate Wladislav Jagello (1490-1516). But the reign of a very energetic king has usually provoked a reaction, as happened on the death of Louis the Great in Hungary and of Edward I. of England. Before Matthias, the nobles had not had a strong ruler for a long time, and after his death they wished for the days of unrestricted liberty once more.

Directly Wladislav II. ascended the throne all the great nobles were united in the belief that the more power they could gain for themselves the better, and now it was political power they aimed at, and not as in former days, sovereignty over certain districts. They now tried for the first time to modify the constitution in such a way as to confer upon themselves additional rights. Constitutional government had been developed, and the great nobles found themselves with less influence over the gentry than before, so they resolved to acquire for themselves by means of legislation a position of greater authority.

Recent events had shown them that the alliance of king and gentry might easily become dangerous to themselves. The reign of Matthias had been hard for them to bear. Before his time the magnates had benefited most from the rule of weak kings, while the gentry and lower classes had gained most consideration from Matthias, who frequently showed severity in his dealings with the magnates. This lesson was not forgotten and the great nobles sought to prevent the recurrence of a similar state of affairs. The first laws they passed showed what were their aims. Their chief purpose being to assure the reign of a weak king they sought to place all the executive power in their own hands. They tried to secure independent rights and powers to the council in which they were allpowerful. They secured the passage of a law that the king should never consult foreign advisers in Hungarian affairs. No offices or dignities were to be conferred upon foreigners but only upon the Hungarian nobles. The "sacred crown" had always been surrounded by a halo of 


\section{THE JAGELLO DYNASTY.}

almost religious veneration, and its custody carried considerable importance with it, especially when there were rival claimants to the throne. The magnates accordingly demanded that the custodians of the crown should be elected by the prelates and the barons from their own ranks. The great national symbol was not to be taken from them on any account, and the captain at the royal castle of Visegrád had to swear to its custodians that without their consent he would not hand over the crown to anyone whatever, not even to the king himself. They made even the king's power of inflicting punishment subject to their control when they enacted that no one could be punished for treason save with the consent of the prelates and barons. Without the same consent, the king could not make grants of land of more than a certain extent.

The magnates gained considerable influence over foreign policy by enacting that the provinces conquered by Matthias were not to be restored to their former possessors without their concurrence. The king could not by himself decide how these territories were to be dealt with, and if he should restore them in consideration of a sum of money without the consent of the magnates, the money was to be retained by them along with the crown, and the king should use it for the benefit of the country in a manner to be approved of by them.

These laws meant a very considerable increase in the constitutional powers of the council consisting of the great nobles.

In 1498 the magnates succeeded in saving from punishment an official of theirs who had defended a fortress placed by them in his charge against the king and the nation, in spite of the fact that the superior of that official had been punished for treason. They were strong enough to defy the law. Loyalty to them in certain cases counted above loyalty to king and country. As such a state of affairs, however, was likely to lead to discontent, they saw the necessity for strengthening their position by law as 
they could not count upon the confidence of the public. During the reigns of Sigismund and Albert they had not needed to do this. The importance of their services to the country was then the foundation of their claim to influence, but since that time they had done much to destroy the nation's confidence in them, and it remained to be seen whether legal enactments could take the place of real merit.

The reaction against them commenced in the ranks of the gentry. The weak king who had been elected was incapable of any manly resolution. The powerful nobles had found in him the puppet they had sought for. Ujlaki called the king a brute and Szapolyai declared that Wladislav, who spent his days in idleness in Buda, disgraced the Hungarian nation, and they openly refused to obey his commands. The king had to endure all this. He uttered threats and took measures against one or two great nobles, but he could not shake off the dominion of their class.

It accordingly became the task of the gentry to break the exaggerated power of the magnates and to defend the national idea and the supremacy of law, and in 1495 they formed a party in opposition to the great nobles. For some time they too had rejoiced at being set free from the strong hand of Matthias, but events soon made them see the whole situation in its true light. The unlawful conduct of the great nobles, their acknowledgment of the Habsburg's right of succession, the turbulence of the "black army," the prevailing economic distress and the decline of the country's dignity in the eyes of other nations, showed the people that a weak reign did not mean a golden age for them at all, but only benefited the more powerful nobles.

The gentry therefore resolved to gain supremacy for themselves so that they might restore order in the country. They were undoubtedly endowed with great qualities; they were the backbone of the nation, but they had yet to show that they were capable of playing a leading 


\section{THE JAGELLO DYNASTY.}

part. Their organisation was elastic enough to allow of their welcoming to their ranks all the progressive elements of the nation, so that they were really representative of all that was best in the community.

They had a strong class feeling, which gave them power for assimilation and aggressive action, and they were thoroughly Hungarian and helped to maintain the Hungarian character of the nation and its government.

In treating of the reasons for the preservation of the Hungarian state it has not been necessary to speak of the dangers due to the presence in the country of inhabitants of foreign origin. Yet the number of such foreigners was very great. Since the time when the Hungarians entered their present home, a large number of the dependants of the aristocracy were Slavs. The Arpád kings induced many foreigners to settle in Hungary.

The tolerant nature of the Hungarians permits of their valuing highly the good qualities of other races, and they welcomed as settlers those who were skilled in some industry. Together with these immigrants from the west there came also nomadic tribes from the east. Thousands of Christians of various nationalities, flying from the Turk, also found shelter in Hungary. As a result of these events it came about that a large number of the burgesses and of the vassals of the nobility, were foreigners. If in spite of this, the Hungarian character of St. Stephen's realm was never in danger, the merit is due to the assimilative power of the gentry. The enemies of Hungary have often taunted her with the fact that many of her great men have been of foreign extraction, yet that is really a sign of her eminence.

Of talented nations there have been many, yet few have been able to so attach to them the great men of other races that these should cling with heart and soul to the country of their adoption and really become her sons.

To do this demands some special quality on the part of a nation, and this quality Hungary possessed in an eminent degree. 
The gentry were not really separated by any distinct barrier from the magnates. The two classes were in fact so intermingled as to form practically one class. Those of the gentry who had risen to the higher ranks of the nobility could influence the gentry class to some extent, and yet there was never any question of that class blindly following the lead of the higher nobility. They were intensely conservative, and were accustomed to a position of authority even though within a comparatively small circle. Their outlook was not wide but they clung obstinately to certain leading principles. They ran little risk of falling into extremes as the strength of their traditions hindered any very violent change. Even the poorest gentleman had the right of audience of the ling, a circumstance which made it easy for the monarch to become acquainted with the persons and opinions of his subjects, and to induce them to give him their willing though not unconditional support.

We have seen that whenever the gentry entered the field of action it was always with the twofold aim of maintaining the unity of the nation under the supremacy of the king, and of safeguarding the country's freedom. It was always into the right scale that they threw their weight. They chose their leaders well and were loyal to those who deserved their fidelity. This had been the case under the Arpád kings, and more recently in Angevin times when for the sake of order and unity the gentry had decided for a strong government. In pursuit of the same aims, they became the atlies of the immortal Hunyadis, and even during the critical times which followed the defeat at Varna it was always the gentry whom we find at the post of danger, zealous in the defence of their country.

But at the period now under consideration a new task fell to their lot. The king did not lead the nation, and the magnates were banded together in a selfish pursuit of their own interests. The question was whether the gentry could step forward and take the lead in such difficult cir- 


\section{THE JAGELLO DYNASTY.}

cumstances. 'They had many of the great qualities which are to be looked for in the well-to-do citizens of a free state, yet they were an unorganised crowd and it was very problematic whether they would prove equal to the task. The effort however had to be made, and they formed themselves into a great national opposition. At first they followed John Corvinus, but their serious action as a political party dates from the time when Szapolyai became their leader. Szapolyai's lofty aims and Verböczy's patriotism, the great wealth and commanding position of the former, and the oratorical powers of the latter, awakened the utmost enthusiasm among the gentry.

The new movement left its mark on the country's legislation. An effort was made to change the internal organisation of the country. The laws passed embodied two principles, which were in keeping with the traditions of the gentry. They desired to give to the government what by right belonged to it, but they were determined at the same time to defend their own rights. They saw clearly that the nation would perish if its government had no authority. In the law of 1498 it is stated that "God has given two means of ruling a people, weapons and rights, the former in order to terrify the wrong-doer and to put a limit to the boldness of men."

A law of 1514 assigns as the cause of all the country's troubles the absence of order and that exaggerated freedom which had become licence. The blame is laid chiefly upon those men who "thought more of their private advantage than of the common welfare, and through whose actions the best laws remained unfruitful." It was these few great nobles who abused their excessive powers, whom it was sought to punish. A heavy blow was dealt to the magnates by the proclamation that the lieutenancy of the county could not be conferred upon any one for life, and that no one could be lieutenant of more than one county, that no ecclesiastic could hold several preferments, and, finally, that with the exception of the Banus and the lord chief justice, nobody could hold several offices. The 


\section{DEVELOPMENT OF HUNGARIAN LIBERTY.}

last rule could never be rigidly enforced, as the king reserved to himself the right to deviate from it with the consent of the barons and the prelates.

The king was entitled to summon before his courts, not only on regular court days but at any other time, any one who used his power in an illegal manner. He was expected to punish those who acted "clearly and openly in defiance of the law." If the wrongdoer were an ecclesiastic the king was to strip him of his preferments; if a great noble his estates were to be confiscated and he himself exiled. Should the king hesitate to inflict the penalty the county might act instead of him. If members of the gentry were the transgressors, the duty of inflicting punishment rested with the king, and their property was to be confiscated.

The new law confirmed the rule of Matthias that the great lords should furnish soldiers in number proportionate to the size of their estates, and that certain of them were to equip separate banderia or companies. The independence of the magnates was struck at by the rule that their troops, other than the separate banderia, had to join the national army.

The gentry strove to improve the position of the king. All mortgaged territories were to be reconveyed to him and he was only to pay to the lender half the interest formerly paid. No dominions were thereafter to be mortgaged by the king on his own authority alone, and if anyone lent money on such mortgages he must lose it. In the matter of grants of land, the king was set free from the control of the barons and prelates, and was empowered to make very considerable grants to Hungarian citizens.

The laws passed by the gentry aimed at restoring order in the country, but it is easy to see in them evidences of a desire on their part to rule. It is true that in them the nation became self-conscious, but their class-selfishness and inability to govern frustrated their good intentions.

They were severe in their treatment of the disorderly nobles, and yet in the law which they passed in the inter- 


\section{THE JAGELLO DYNASTY.}

est of order there was the germ of anarchy. The enactment that in the event of the king's hesitation to inflict punishment the counties were entitled to act instead of him, struck at the root of the king's authority. Not freedom but licence was fostered by conferring on the counties the right to ignore the will of the monarch and to confiscate the property of those whom the king was willing to pardon.

The ambitions of the gentry grew and they began to believe that the country could only be saved if they ruled it. They fought not merely to settle this or that political question in the way they deemed best, but to secure the permanent supremacy of their own class. 'They used with wonderful pertinacity every means which presented itself of furthering their plans. They assured for themselves the decisive word both in legislation and administration. They made the presence of members of the noble class at meetings of the national council obligatory, and thus brought into prominence a question which had long been agitating the minds of many.

We have seen that in England during the thirteentl century the representative system began to develop itself because frequent meetings of the council became necessary.* In Hungary, however, at that period, no circumstances arose which rendered reform imperative, and so unfortunately the old system, involving the attendance of great crowds instead of their chosen representatives, was continued. Since that time, great changes had occurred. The organisation of the counties was such as to favour the evolution of a system of representation, and it gradually became the basis of the parliamentary system. As the need for imposing taxes upon the community grew greater, it became increasingly necessary for the national counci! to meet. The interest of every district and every section of the community demanded that it should be properly represented, because the burdens of which the coun-

* Pages 114-122. 


\section{DEVELOPMENT OF HUNGARIAN LIBERTY.}

cil treated pressed upon all alike. As soon as affairs took this turn the question of electing representatives came very much to the fore, and as the situation had now become very similar to that which in England had led to the adoption of the principle of representation, a similar result followed.

Even in the fourteenth century it had been customary for the king to ask the counties to elect a certain number of trustworthy men, but in one point the Hungarian practice differed from that followed in England. In the latter country, the moment representatives were sent to Parliament, the subordinate vassals of the king lost the right to appear there, whereas in Hungary, every member of the noble class retained his right to attend the national council, if he chose to do so. He was not obliged to attend, and his interests did not demand his presence there, as he was represented even if he did not go in person. In England, the general assembly ceased altogether.

The reason for this difference is to be found in the different antecedents in the two countries. In England the lesser vassals of the crown were on the same social and financial level as large numbers of men who were not crown vassals, and who therefore were not entitled to appear in Parliament. To have allowed that portion of the electorate which consisted of such vassals to retain their ancient privilege of attending Parliament would have been to treat equal elements of the community unequally. That equally important elements should have equal rights was so natural that no one dreamt of perpetuating a privilege which would have allowed one part of the electorate to remain members of the legislative body while the others were shut out, especially when such differentiation would not have corresponded to any difference in real weight.

In Hungary, however, the maintenance of the ancient right did not introduce any differentiation, for the right belonged to every member of the electorate equally and not merely to certain individuals. Accordingly it was to the interest of the whole of the nobility that the right 


\section{THE JAGELLO DYNASTY.}

should not become obsolete. It is true that there were many objections to such a system, for example the indefinite composition of the legislature, but such considerations were not likely to weigh much against a privilege that was popular and backed up by so many powerful interests.

As soon as the new electoral system was inaugurated in England, the old system had to die, while in Hungary the introduction of the method of representation did not terminate the right of the nobles to attend meetings of the Diet in person. But such an arrangement could not be final, for it was inevitable that as the nation became more civilized and gave greater attention to the work of legislation, the most important organ of the community should assume a more definite legal form.

As early as the time of Sigismund, the king and the magnates endeavoured to make the national assembly a purely elective body but their proposals did not meet with general approval. After all, so long as the various sections of the community were in harmonious relations there was no crying need for reform, and the state could thrive with a very primitive organisation.

Directly, however, the gentry resolved to take the lead in the nation, they found the existing situation unfarourable to their plans. They could not trust the elected representatives, who lived permanently in the atmosphere of the Court, and were likely either to be intimidated by the military power of the great nobles, or won over by flattery or favours and distinctions. Moreover, those representatives were very probably chosen from the wealthiest and most influential gentry families, and consequently stood nearer to the magnates than to the bulk of the class whose interests they were to serve. The only method of securing for the gentry political predominance was personal attendance at the Diet, where their numbers would carry the day.

This was why they objected so strongly to the system of parliamentary representation, both during the reign of 


\section{DEVELOPMENT OF HUNGARIAN LIBERTY.}

Andrew III. (1290-1301) and in the fifteenth century. It was during the time of Hunyadi that a law was passed compelling every member of the noble class, excepting only those who were too poor, to attend the meetings of the Diet. The election of Matthias was due to the unanimous roice of the impassioned gentry, and after this success it was only natural that they should attach importance to the right of personal attendance at the Diet. Matthias, however, could not look with favour upon such a system. One so skilled as he was in the work of legislation and attaching such importance to it, must have felt it impossible to treat weighty matters satisfactorily in cooperation with such a curiously mixed crowd, and therefore, after the first meeting of the Diet he appealed to the gentry to send representatives.

As the Diet had to be convened very frequently, and as personal attendance meant such serious personal loss and inconvenience, the gentry became quite reconciled to the new system when their passionate mood had sobered down. The law of 1471 gave a free hand to the king and put an end to government by crowds. The king was to convene the Diet, representing the whole country, but there was no word in the law as to the nobles having to appear in it. The phraseology adopted enabled the king to make the Diet representative in practice without contravening the written law. Even Matthias could not achieve more than that, and he was not able to abolish the right of the nobles to sit in the Diet side by side with the elected representatives if they wished to do so.

After his death eren this result came into jeopardy. When the gentry began again, under the Jagellos, to bid for power, they naturally revived ancient traditions. Some institutions seem to be so closely connected with certain situations, that when a similar situation revives, even after a long interval, efforts are made to revive the institutions formerly linked with it.

When the strong reign of Matthias was over, the gentry strove to restore the institutions for which their 


\section{THE JAGELLO DYNASTY.}

ancestors had fought in the times of Andrew III and of Hunyadi, but they showed more circumspection and tenacity.

In 1492 the Estates commenced their reforms on the basis of the laws of Matthias. They acknowledged that the king could invite them to the Diet "either collectively or otherwise," but they endeavoured to remove the obstacles which stood in the path of personal attendance on the part of the nobles, and which favoured the representative system.

The poorer members of the gentry could not stay long in the place where the Diet was held, therefore it was essential that the time occupied by the sessions should be shortened. It was decided that after the time appointed for assembly, no members should be waited for more than four days; those who did not appear by then must concur in the decisions arrived at in their absence.

In 1495 it was enacted that thenceforth the counties should not send representatives, but that every member of the nobility must personally attend the Diet, thus cancelling the result of many well-conceived efforts of the past. The king was to issue invitations a month before the time fixed for the opening of the assembly. Every important act was to be previously prepared in the council of the barons. This prevented the magnates from delaying the commencement of proceedings under the pretext of preliminary discussions as they had frequently done.

An Act of 1498 limited the session to fifteen days. If any member did not attend, or arrived too late, he incurred a penalty, as did also the county lieutenant for allowing him to neglect his duty.

These reforms made the gentry practically omnipotent in the Diet. One thing still remained to be done, and that was to widen the sphere of action of the Diet, or at least to define it. In 1495, when personal attendance had been made obligatory upon the nobility, it was also enacted that " everything that affected the welfare of the country" must be discussed and settled agreeably to the 


\section{DEVELOPMENT OF HUNGARIAN LIBERTY.}

will of the Diet. This law drew practically every question into the sphere of action of the national assembly. Its position was strengthened, and what had formerly been merely custom became law.

Among many other innovations there was one of considerable importance. In 1504 the most valuable right of the Diet, that namely of voting taxes, was affirmed anew. Neither the counties nor individuals were allowed to help the king with money on their own account. If anyone paid taxes which had not been voted by the Diet, he was to be excluded from the ranks of the nobility.

But even an assembly thus constituted, and so entirely under the influence of the gentry, was not sufficient to assure the supremacy of that class. An assembly which only met occasionally could not perform all the everyday work of the State. This could only be done by permanent bodies, and so the executive power rested with the king and his officials. As personal attendance was obligatory, the burden it imposed was so heavy that although the sessions were shortened it was impossible to hold them often. Accordingly, while in former times the nation had demanded annual assemblies, it was now decided that it would be sufficient if the Diet were convened in every third year.

That the executive should be controlled by the gentry was urgent. There are times when people resolve upon the most daring courses in the hope of putting an end to age-long evils. Such an epoch was that which in Hungary preceded the battle of Mohács (1526). The gentry were confronted by the problem which during the Middle Ages was solved by no country, that namely of obtaining systematic control of the administration, a problem which had become more pressing than ever before.

When speaking of the age of Sigismund it was mentioned that the community did not then feel the need for reform, that is, a change in the relations between the executive and the legislature, since the same factors of 


\section{THE JAGELLO DYNASTY.}

the nation controlled both the Diet and the administration.

Under the Jagellos all this was changed. The gentry with their own independent policy were predominant in the Diet, while the exccutive power was in the hands of the king and the great nobles. With a weak king like Wladislav II., a vigorous State life was only possible if either the powerful nobles and their party could capture the national assembly or if the gentry could seize the executive power. Since in 1495 the Diet was organised in such a way that the superior numbers of the gentry rendered them supreme, it was inevitable that the latter attempt should be made. In respect to these efforts, history repeated itself. If we glance back at the times of Andrew III., Queen Mary, John Hunyadi, and Matthias, we find the gentry continually battling for pre-eminence in the Diet, but as the composition of that body varied in different periods, the results of their efforts naturally varied also. All the time, in spite of the fluctuating composition of the Diet, the leading part belonged to the higher nobility. That was the state of affairs until the accession of IVladislav II., when the gentry began by means of the position they gained for themselves in the Diet to get a hold over the executive. It was in 1495 that they took the first step. Following ancient traditions they commenced with much discretion. They were satisfied with the innovation that fourteen members of their class should be nominated as assessors to the council. These assessors merely performed the functions of judges and took no part in the political discussions of the royal council. They were nominated and paid by the king. In 1498 a further step was taken. The number of assessors was increased to sixteen, and eight of these were entitled to attend every meeting of the council. Those eight assessors had to promise on oath not only to judge "without partiality" as before, but also that in the royal council they would "discuss everything faithfully and with an eye to the welfare of the nation." These men were practically members of the government, and there 


\section{DEVELOPMENT OF HUNGARIAN LIBERTY.}

was a link between them and the Diet because they were no longer appointed solely by the king, but jointly by the king and the nation. Their vocation was to represent the gentry in the king's own council, and often against him, and accordingly they received their salary not from the king but from the class which sent them.

In 1500 there was a further accession of influence. All the members of the group of assessors, namely four prelates, four great nobles, and sixteen members of the gentry class, gained the right to attend every meeting of the council, whatever subject might be under discussion.

This was no gain to the first two classes, because they were already members of the council by virtue of their rank, but it doubled the number of representatives of the gentry in the council.

Half the number of assessors, composed of four magnates and eight members of the gentry, had to live in Buda and attend every meeting of the council. The Diet took care that this little group should remain in constant touch with itself. The gentry were fighting not in order to enable a few individuals of their number to gain a position of influence in the administration-that had always been possible-but to secure their supremacy as a class in the executive body. However many members of the gentry may have had a seat on the executive council, the result aimed at would not have been achieved unless they had remained in contact with the bulk of the gentry, who controlled the legislature.

In 1495 the gentry had only taken part in legislation, but towards the end of Wladislav's reign they formed the majority of the executive council. Only one task remained, namely, that of subordinating the king to the council, and in 1507 that also was achieved. It was enacted that the king could only decide any matter with the council, and if he issued any order without their knowledge, it was invalid.

The gentry were not unmindful of the lesser organs of administration, and in them too they sought to assure 


\section{THE JAGELLO DYNASTY.}

their predominance. In 1495 it was enacted that the county lieutenant, the deputy lieutenant, and the szolgabirós (sheriffs) should in all their administrative acts be controlled by the county, and that any official acting without the county's authority was to be punished.

In 1500 it was added that if the lieutenant of the county should neglect his duty in the matter of incorporating private banderia with the troops of the county he should be punished by the inhabitants. An act of 1504 took from the lieutenant the right of appointing his deputy without the county's consent. By this law the deputy lieutenant, who had been his chief's confidential assistant, was changed into the county's official.

All these results had as their common source the desire of the gentry to take the lead in all branches of government. The roots of their power were the Diet at the centre of the state, and in the counties the members of their own class.

It was very doubtful whether their efforts could lead to success, because in that age they did not form the natural pivot of the state, and so their supremacy was something abnormal. They were forced to the attempt, because the natural leaders of the nation, the king and the magnates, had sinned against it and destroyed its confidence. It was a sad omen for Hungary that those powers which could not be replaced had proved unworthy of the part assigned to them, for it made disaster inevitable. The gentry tried to grasp the reins of government, but to hold them was difficult because those who had let them fall were still powerful, and standing so much higher than the gentry in many respects refused to obey them. It was only a theoretical supremacy that the gentry gained. They really ained at the impossible.

One paragraph of the law declares that every matter affecting the welfare of the country comes within the sphere of activity of the Diet, and yet another paragraph says that the assembly must not sit for a longer period 


\section{DEVELOPMENT OF HUNGARIAN LIBERTY.}

than fifteen days. But how could the Diet deal with every affair of state in fifteen days? It was not their fault that the gentry were guilty of this inconsistency, for the system made self-contradiction inevitable. The source of their influence was the Dict, and if they wished to guide the state they must entrust to that body the conduct of as much of the country's business as possible. On the other hand if they desired to ensure the personal attendance of large numbers of their own class at the meetings of the Diet, they must restrict the duration of those meetings. Each of these decisions was necessary yet they were absolutely inconsistent with one another.

And this is not to be wondered at. An unnatural state of things can only be maintained by unnatural means, and even then only temporarily and partially. In spite of the law, the gentry very often did not attend in large numbers. The king frequently ordered the counties to elect representatives and they obeyed, in defiance of the law. Frequently, too, difficult and important quesiions occupied so much time that the assembled crowds left the assembly, entrusting the termination of the work to a few. The demands of real life were stronger than any written law, stronger even than the passion which politics kindled. Consequently, the great nobles were often able to retain and use the advantages of which others sought to deprive them. The insecure foundation of the power of the gentry was revealed by the anxiety which they showed to prevent any electoral system from gaining ground in the country. If the middle classes were so weak that they could not reckon upon carrying the elections, how could they hope to retain the executive power in their hands? If the representatives elected for only a few weeks were likely to fall under hostile infuences, how could it be hoped that the members of the gentry who, in the royal council, worked in permanent connection with king and magnates, should remain loyal to their class? The question was whether the influence which broke the power of the gentry's officials 


\section{THE JAGELLO DYNASTY.}

would not find a means to control the crowded assembly itself.

The anxiety of the gentry was not without cause. The social standing, the wealth and power of the magnates, were able to cause a division in the ranks even of the solid middle-class majority of the Diet. The great nobles had many dependants among the gentry. Those who lived in the environs of their fortresses, and who served the magnates in rarious ways, naturally followed their lead in the Diet, and not infrequently these formed the majority of the chaotic crowd assembled there. Canvassing was practised at the meetings, and bribery was freely used. Every law was ineffectual. There were many who were willing to sell their rotes because they attached more importance to money than to politics, while there were some ready to purchase, because they valued political influence more highly than money. As many of the gentry were too poor and uncultured to understand the entangled problems under discussion and to take up a firm attitude in relation to them, and as, on the other hand the power of the great nobles was still an actuality, there was no written law powerful enough to destroy the influence of the magnate class. Even in the very centre of their power the gentry could not withstand the benumbing influence of their enemies. On one occasion they hung a blood-stained axe upon a tree at a meeting of the Diet, and swore by that to kill anyone who created disunion among them.

If they had to take such precautions against disloyalty on the part of members of their own class in the Diet itself, it is not to be wondered at that in the executive council their theoretical supremacy was still less effective.

The laws which aimed at confiding the whole work of administration to the council and at subordinating the council to the gentry, were themselves imperfectly conceived, and the shortcomings of a theoretical creation became manifest on contact with reality. The king was 
not in fact entirely dependent upon the council, because the new law only declared that such acts as he performed "without the knowledge of the council" were invalid.

When in 1490 the magnates had the upper hand, they clearly stated that the king might not settle any matter affecting the state-without "the clearly expressed consent and free and voluntary decision" of the barons and prelates, but at the period now under consideration the matter was one not of agreement but of information merely. It is possible that the ambiguous words were smuggled into the text of the law by the adherents of the court in order to defeat the purpose of the assembly. The Diet only decided upon the general principles of a measure and its members then dispersed, tired of their labours, and left the matter in the hands of permanent officials, who were under the influence of the more powerful nobles. It is not unlikely, therefore, that they endeavoured to reduce to a minimum of effectiveness the legislative achievements of the gentry.

Even in the council the gentry were not supreme. $\mathrm{Jt}$ is true that they constituted the majority of that portion of the council which was obliged to be in attendance upon the king, yet they were not bold enough to exclude from the council the wealthy and powerful nobles, without whose troops victory in war was very unlikely, and who formed the natural centre of the life of the state; whose influence was felt even by the strongest kings and to whose words even Matthias had to give heed. Foreign rulers only esteemed a contract if it were signed by the great nobles. Their real power was so great that it was impossible to exclude them. When in the year 1500 the number of assessors was increased, it was also enacted that the other councillors of the king, that is to say the barons and bishops "who already sit in the king's council " should always be admitted "in the usual way." The law which established the principle that the council should always be previously informed of the king's intentions applied to the rest of the council as well as to the 


\section{THE JAGELLO DYNASTY.}

assessors. The gentry therefore could not count on the support of the majority of the whole council.

Moreover, the real organ of the executive power was not the Council but the body of high officials, the Palatine, Chancellor, Treasurer, Chief Justice, Banus of Croatia, Vajda (or Seneschal) of Transylvania. These were at the head of the administration and it was their commands which the people were accustomed to obey. The assessors, who were only elected for a few years and who merely discussed matters but could not command, who had no army of subordinates to make their will effective and whose position was not supported by ancient traditions, could only play a minor part. What the gentry really needed was to make the administration dependent upon themselves, for until they did this their power could easily be torn from them. But this is just what they could not achieve, even in theory. It was the king who disposed of those dignities. It is true that he had to listen to the opinion of the council, but not of the whole nation, and even so he was not obliged to follow the advice given. The office of Palatine was theoretically elective, but the court party realised so clearly the importance of the post that they spared no efforts to secure the election of their own candidate and their skilful tactics made their victory certain. Even what the gentry did really gain was due less to their own strength than to the alliance which they formed with Szapolyai, the most powerful nobleman in Hungary. Without his support they could not give effect to their wishes. This state of affairs contained an element of danger, for an ally whose interests were naturally opposed to those of the gentry was all too likely to seek to use them as a tool. The alliance was also dangerous for ancther reason. The power of Szapolyai was great enough to menace the throne and with the support of the gentry he could gain the crown for himself. Hence King Wladislav, in spite of the weakness of his will, was 
driven by the instinct of self-preservation to exert himself against the coalition. The ling sided with the magnates, who also dreaded Szapolyai, and this involved opposition to the gentry. The question of the constitution, and the distribution of power, became pre-eminently a dynastical problem. The gentry, although desirous of increasing the king's power because of the obvious necessity of a strong ruler, were forced in spite of themselves, to become the enemies of the ling. Szapolyai's ambition blocked the only path which could have led to a solution of the difficulty, an alliance, namely, between the king and the gentry. The king and the magnates were compelled to unite, and in alliance they could easily withstand the gentry. Formerly king and magnates had struggled together for supremacy, and the gentry had sided now with this party, now with that, but when the sentry themselves tried to gain the upper hand, the former combatants joined forces and turned against the common foe. As a result, the gentry were unable during the reign of Wladislav $I I$. to achieve their aim. Although they had reformed the organisation of the state, yet they were unable to control the administration.

After the death of Matthias there was at first a reaction against his system. A nation usually judges its government very unjustly, seeing chiefly its shortcomings, and being blind to its merits. But if the succeeding government turns out to be worse than its predecessor public opinion veers round again, and dwells only on the merits of the system it had formerly condemned.

A reign so unhappy as that of Wradislav could not but show that of Matthias glorious by contrast, and when the gentry perceived the increasing disintegration of the State they sought a remedy in the restoration of the former situation. A national monarch, they thought, would be the salvation of the country, and patriotic feeling urged them to seek a king of their own race. It is certain that a king of the same race as those he rules is the most desirable ruler for a country, for anything which 


\section{THE JAGELLO DYNASTY.}

links a king to another country is likely to cause difficulty. But it is hard, in the absence of any recognised royal line, or of any extraordinary circumstances which might exalt one man far above the rest, to find a man whose rank and antecedents would incline the whole nation to accept him as king. To give the crown to someone quite unworthy of it merely because he was a member of the nation would be a disastrous action. At a time like that which followed the death of Matthias, with the Turks threatening on the east, and the Habsburgs on the west, strenuously endeavouring to gain the Hungarian crown, the election of a mediocrity to whom many regarded themselves as equal in rank, would have been especially dangerous.

If Matthias could have bequeathed his prestige to his illegitimate son, John Corvinus, and the nation had at once elected him, the new king would probably have met the needs of the situation, but as this opportunity was missed and John Corvinus, branded with illegitimacy, sank to the level of a subject, he became an unsuitable candidate. At first, however, many of the nobles ranged themselves around him, but upon his death the ambitious Szapolyai turned the enthusiasm of the gentry concerning a national monarch to his own account. But Szapolyai was quite unfit to be king. Neither the past merits of his family nor his own talents, raised him above all others; only his wealth and ambitions were kingly. The nation would certainly not have regarded his ascent to the throne with satisfaction.

A wiser policy was that of recognising the hereditary rights of the Habsburgs. By pursuing this policy the nation could avoid one great danger resulting from the persistent resolve of the Habsburgs to seize the throne at any moment of weakness on the part of Hungary. As Providence did not bestow upon Hungary another Hunyadi, a man born to rule whatever his ancestry may have been, the nation had to seek in other lands for a suitable candidate, and no one more suitable could be found than 


\section{DEVELOPMENT OF HUNGARIAN LIBERTY.}

the powerful neighbour whose alliance was not to be gained except at the price of the Hungarian crown.

The gentry pursued the policy of a national ruler. They passed a law that the envoys of foreign princes were not to attend the meetings held for the purpose of electing a ling, and also that in the event of the dynasty becoming extinct, any new ruler must be Hungarian by race. The government, however, pursued a different policy, that namely of alliance with the Habsburgs.

Wladislar, at the commencement of his reign, in spite of the protest of the gentry, entered into a contract with the house of Habsburg, for the purpose of securing alliance by marriage, and before his death he arranged a meeting with Maximilian with the object of furthering the cause he had at heart. In spite of the wishes of the Diet and of the council of the nobles, he made every possible effort to cement the union with the Germans and to secure the succession of the Habsburgs to the throne.

In 1511 , that is to say at a time when the laws passed in the interest of the nobles, were in force, another instance serves to show that the power of the gentry was more apparent than real. The German Emperor and the French King invited the King of Hungary to be their ally against Venice. Most of the nobles were in a warlike mood, and desired to regain Dalmatia. The envoys declared their message before the Diet. The assembly was asked if it was to be peace or war, and the decision was for war. Apparently, the Diet was exercising sovereign rights, yet in fact nothing happened in accordance with its declared will. The Palatine and the Primate arranged everything between themselves, and the country took no part in the war. Public opinion had very little weight, and the nation's policy was determined largely by court cliques.

This was evident during the whole reign of Wladislav. In spite of the written constitution, the country was really governed by a few infuential men at court, and the lesser nobles were unable to control them. 


\section{THE JAGELLO DYNASTY.}

Thomas Bakács, the ambitious and talented cardinal and the leading member of the court party, was the main spring of the government. The lesser nobles hated him but could not break his power. They attacked him so bitterly in 1497 that the ling had to deprive him of the chancellorship, but immediately afterwards he appointed him Archbishop of Esztergom, and to the end of his reign the king followed his advice.

The long struggle for supremacy between the different classes of the state plunged the country into anarchy. The various authorities contended so fiercely with one another that there remained practically no authority whatever.

Taxes were rarely asked for and rarely voted, because the contending parties dreaded unpopularity, yet for taxes there was an urgent need. Even taxes which had been voted were not collected because the country lacked all discipline and no one was ready to obey. The king had no great private fortune and so could not maintain an army. The "black army" accordingly revolted as the soldiers could not obtain their pay. The very things which in the hands of Matthias had been a blessing, now became a source of danger, and the government had to break the weapons which the nation needed more than ever. The frontier fortresses were neglected. The magnates in the provinces transgressed every law with impunity, for to restrain them needed a powerful government and the gentry could not form one.

The saddest consequence of this anarchical state of affairs was the peasant revolt under the leadership of Dózsa. The turbulent magnates were cruel and exacting towards the peasants who were goaded into rebellion by their tyranny. The peasants played a very subordinate part in mediæval Hungary. They had to work, to pay, and in addition, to shed their blood in the wars, but they had no influence upon either the central administration of the state, nor the county. 


\section{DEVELOPMENT OF HUNGARIAN LIBERTY.}

On the other hand, they were not slaves. They had the right to move freely about the country and to own property. If the monarch was strong, he defended the rights of the peasants. It was his most sublime prerogative to protect the weak. He was able to maintain the balance between the different classes of society by succouring the oppressed and attaching them to himself.

But when the monarch was impotent, the situation of the peasant was intolerable. Matthias the Just gave protection to the peasants, but also assigned to them duties. After his death the protection ceased but the burdens remained. What the state no longer demanded of the peasant, the landowner claimed for himself, and the burdens were not rendered lighter by their becoming unlawful.

Bathory said threateningly that any man who should try to accuse him before the king ought to have two heads, because he would cut one off before the accuser could reach the court. The immediate cause of the peasant outbreak was the prevailing anarchy. The weak government could not induce the nobles to make the necessary military preparations against the Turks, so the idea suggested itself that the people themselves should perform the task which their leaders neglected. It was the boundless selfishness of the contending parties which forced the sword into the hands of the embittered peasants. The constituent factors of the community were at war with one another, all belief in authority was shaken, and the utter overthrow of the state seemed probable. At such a time, when disorder reigned everywhere, and bold enterprises were the order of the day, the peasants also conceived the plan of achieving their own emancipation. Why should they have remained the only sober class of the community?

Hence the terrible revolution, the fruit and wellmerited punishment of the immorality of the age.

The cruelties which attended the suppression of the 


\section{THE JAGELLO DYNASTY.}

rising also reveal the character of that unhappy time. The nobles in their pursuit of vengeance were merciless towards the conquered peasants. The selfishness and vindictiveness of the conquerors were a dark spot on the fame of Hungary and a blight upon the country. 


\section{CHAPTER XIV.}

\section{LOUIS II. (1516-1526).}

In the reign of Louis $\mathrm{II}$. the same parties were cont€nding as before, only the peasants had been silenced, and they watched events with bitterness in their hearts. When danger began to show itself upon the horizon the peasants could hardly be counted upon, although the country sorely needed the help of all her sons.

The magnates and the gentry were still at daggers drawn, pursuing the same aims as in the days of Wladislav.

At first, some kind of compromise was arrived at, but in 1518 the magnates gained the upper hand and achieved all that they had been in vain endeavouring to accomplish since the year 1490. The chief element in their programme was the same as it had been in 1490, namely, that the executive power should be in the hands of a council of magnates and that the Diet should exercise no control over this council. However, past experience urged upon them the necessity of creating a more practical organisation. They formed a government of persons whose number was fixed and was independent of the king. The power was placed in the hands of a council consisting of four barons and four prelates, in addition to the Palatine, the Chief Justice, the Treasurer, and the Chancellor. Taught by the past they demanded that half of these officials should be obliged to attend the meetings. Three meetings were to be held every week and the king could only communicate with foreign powers through the intermediation of the council. Every public matter, even the supervision of the royal household, came 
within the sphere of the council's activity. As in 1490 , the magnates again declared that important grants of land and ecclesiastical appointments could only be made with their consent. In their own interest they decreed that war taxes should be paid by the tenants of those noblemen only who did not equip banderia. They emancipated themselves from taxation when they appointed their own officials to collect the taxes.

All these were fatal mistakes. The supremacy of any one class in a nation can only be accepted by the other self-respecting classes, so long as it uses its power for the common good; as soon as it uses its influence to further its own selfish aims it is bound to fall.

There had been a time when the great nobles recognised this truth and voluntarily undertook the two-fold burden of the equipment and taxation of their dependants and the maintenance of separate banderia. Now their selfishness injured themselves. The bold attack of the gentry had not taught them that they could only strengthen their position by taking the lead in making sacrifices for the good of the state. They therefore deserved the mistrust and dislike of the nation. Their action in levying taxes at the very time when they emancipated the tenants of the richest noblemen from taxation had the nature of a challenge. The gentry moreover were not resigned to the decisions of the nobles. These had elaborated their scheme presupposing the consent of the Diet. The gentry, however, withheld their consent and met the action of the magnates by passing into law their own programme, which remained unaltered. According to this programme the supreme power was to rest not with the council but with the Diet, in which the gentry were predominant. They demanded that the council should be subordinate to the Diet, and they pursued this purpose more stubbornly under Louis II. than they had done in his father's time. They were not content that the Diet should elect the gentry members of the Council, but insisted that it should choose the harons and prelates 
as well. The majority of the council was constituted by the gentry. The whole of the work of administration was performed by the council, which, together with the king, was placed under the control of the Diet. As there were difficulties attached to administration by a body composed of sixteen members of the gentry class, four barons and four prelates, an effort was made to lessen the difficulties by appointing special executive officers. Such were the two Treasurers, who had to be elected from the nobles. Their duty was "to carry into effect every decision whether of recent or of earlier times" and to "conduct all the affairs of king and country." They had to see that the taxes which had been voted were duly collected. They levied troops. It was their task to retake possession of the royal estates which had been alienated, and for this purpose the armed forces of the counties, and eren of the whole nation, were placed at their disposal. They also gained striking powers in the matter of proceedings against wrongdoers.

If the king, whose duty it was, refused to execute the law or endeavoured to hinder its execution, or if the Palatine acted in a similar way in cases which came within his jurisdiction, the treasurer was to carry out the law. His right was superior to that of king or Palatine. Care was taken that the treasurer should exercise this important right under the control of the council, and especially of the gentry members thereof.

The treasurer could only take action on being requested to do so by the assessors. The assessors also chose one of their number without whose knowledge the treasurer could not collect revenue or allow expenditure. Once a year a report had to be given of the state of the royal treasury. Certain acts of negligence on the part of the treasurer were by law punishable by death, while other acts only inwolved the loss of office and possessions.

The authority of the treasurer was given a foundation in the counties as well as in the centre. In every county some members of the nobility were elected whose duty it 
was to ascertain the incomes and the possessions of the inhabitants, in accordance with which the obligation of equipping soldiers and paying taxes was determined.

But these efforts on the part of the gentry to improve the administration were not successful. For a time they secured to the gentry the leading part. The assessors, upon whom the law conferred such exceptional powers, gained considerable influence, yet they were not adequate to their task. They were unable to establish order in the state. In the provinces they were never very strong and in the matter of taxation, and the equipment of soldiers, they did not achieve more than their predecessors. Party strife weakened the country as much as before, and no one was able to give a strong lead to the nation.

The party of the magnates gained ground, through the failure of their rivals. While the gentry were thinking of war against the Turks and were seeking help abroad, the king, acting on the advice of the magnates, concluded a treaty of peace with the Turks. The influence of the king was increased by this step, and when, after the death of Perényi, a new Palatine had to be elected, the Court party won a decisive victory over the gentry. It was not Szapolyai who was elected, but Bathory. The gentry were defeated in their own fortress, the Diet.

It is not necessary to give a detailed account of these party contests; it is enough to say that in the following years the royal council did not work in its new form, and that in consequence of the jealousy between the Palatine Bathory and Szapolyai, and also of the weakness of the king who was not able to control them and who could not find a military leader acceptable to those two dynasts, the fortresses of Szabács and Belgrade were talien by the Turks.

Under the influence of this disaster the two parties approached each other a little. In 1521 a law was passed which aimed not so much at strengthening the hands of this party or that, but at the organisation of the country's 


\section{DEVELOPMENT OF HUNGARIAN LIBERTY.}

means of defence. This meant some advance. Taxes were imposed greater than had ever been known before. Not only had the vassal or tenant class to pay, but every nember of the nobility without exception had to hand over the half of his income to the treasury. All articles of every day consumption were heavily taxed. The money thus gained was to be used for providing soldiers. The ancient tradition of obligatory military service was departed from, and this departure was a sign of the unhealthy condition of society. At a time when danger threatened the country from every side, the nation abandoned its right to summon every citizen to its defence.

Following the example set by Matthias, the whole nation should have been armed, and in addition, a regular army formed. But this was impossible, for it would have needed a state of discipline on the part of the administrative body and of the whole community which could only have been brought about by the energy and genius of a Matthias.

Even he, in that troublous time, might have found it impossible to cope successfully with the prevalent selfishness. Under the circumstances it was only by recruiting paid soldiers that a sufficient force could be brought together. The collection and handling of the money, and the leading of the army were not entrusted to the ordinary administrative machinery. Two specially elected nobles enforced payment and had to hand the money over to the treasurers, two of whom belonged to the magnate class and two to the gentry, in order that they should pay the army under mutual supervision. At the head of the army were two captains appointed by the king.

It was of ill omen that there should be so little confidence in the ordinary administration. The election of the treasurers from the wo rival classes shows that neither party could rule alone, and also that they guarded their position jealously. The danger to the country put an end to actual strife between the parties but it did not establish sincere peace. For did the joint dominion 
prove a success. Instead of the millions of money expected only thousands came in. The law remained a dead letter. It was impossible to organise a powerful army, and it was necessary to return to the ancient system, imperfect as it may have been. The king lost the opportunity of restoring his prestige and guiding the development of the country in the right direction. The patriotic enthusiasm soon died away and party strife recommenced. In the absence of King Louis, and while the Palatine Báthory was governor, the Court party again began to act aggressively, and accordingly in the year 1523 , the gentry resolved to make a vigorous attack upon them. When they were asked for money they replied that they would only give it on condition that Bathory was dismissed from his post. It seems surprising that the gentry did not more often use the powerful weapon of the refusal of money.

In England when Parliament attached certain conditions to the grant of money and by that means wrung concessions from the Plantagenets and Lancastrians, the kings had waged wars necessitated by their own ambitions and not by the nation's interests, and accordingly the people could refuse their support. In Hungary, however, war was inevitable; it was the gentry class which sounded the alarm and was decidedly opposed to any truce or peace. They could not, therefore, very well deny the king the money necessary for prosecuting the war.

The threat of the gentry was, however, successful. The king made Báthory resign, but soon after he reappointed him; he also appointed to the Archbishopric of Esztergom the great adversary of the gentry, the talented Szalkai, the most selfish politician of the age.

These reactionary steps brought the long struggle to a head. A revolution broke out, and the government deserved this disaster, for it had done everything that was likely to lead to such a result. Then it grew frightened and became conciliatory, but it did not keep its promises. 
It could neither awaken fear nor respect, and it had taught its adversaries that only violence could bring success.

Until the year 1525 the contest between the embittered gentry and the jealous monarch paralysed all law and plunged the state into misery. Twice was the Diet dissolved without coming to any valid decisions.

The gentry were openly disobedient. They summoned an armed assembly with the set purpose of reorganising the whole state. The king summoned the estates to another place but was not obeyed. For thirty years the gentry had struggled to secure better government for the country and to keep the ling subject to their influence and substitute their own supremacy for that of the magnates, and they had not succeeded. The king had never sympathised with their aims and the power of the magnates was greater and more real than theirs. On paper the gentry possessed important rights but they had not strength to enforce them. Now they chose the method which alone could give effect to their will. That portion of a nation which is inferior in privileges can only force its way to the front by means of a successful revolution.

The king grew alarmed. He knew that unless he yielded, civil war was inevitable, while if he approached the gentry he might moderate their action. The gentry were sure to be ready to fight for their king if he were a just king to them. Only a few years before, when he dropped Bathory for their sake, they became reconciled at once, for all Hungarians are royalists at heart. And there were other circumstances which encouraged the king to make the attempt. Szapolyai, the leader of the gentry, coveted the wealth of the Ujlaki family, so there was a possibility of bribing him.

$V$ erböczy was peacefully disposed in consequence of his royalist sentiments as well as his dread of a lawless state of society and civil war. The king knew that if he could awaken Verböczy's confidence in the sincerity 
of his friendly overtures, he could count upon his friendly offices.

Louis therefore appeared at a meeting which he had himself forbidden. He trusted that he could stave off the danger by promises. Tardy yielding, however, rarely brings the expected result. Yet all the circumstances on which he had relied justified his confidence and smoothed matters to a great extent. The impassioned crowd did not abuse their power. They treated the monarch with respect and abandoned at his request many of their demands. They exhibited a degree of self-control rarely found in a crowd. Yet in spite of their moderation they compelled the king to accept more far-reaching reforms than he had contemplated. The gentry had at length achieved their aim and become the real masters of the State. They exerted their influence upon the whole machinery of government. Báthory was dismissed from his post by the king and the gentry sought to replace him by one who would vigorously execute the laws which they passed. "Let us choose a man who can sympathise with the griefs of our class," they said, and in Verböczy they saw the man they desired and they at once elected him.

They also wished to fill the other principal offices, but as the appointment was an undoubted prerogative of the king they were content that the king should select men whom they also trusted. In this way a government was formed from their own adherents which was really under their influence. The eight assessors elected from their ranks had the right to attend all meetings of the council together with the Palatine, Chancellor, Chief Justice and Treasurer. The other magnates might attend the meetings but they had no decisive vote. Foreigners were not allowed to fill any office.

The provincial governing bodies were not orerlooked. The county lieutenant, who was the king's principal official, could only be appointed with the consent of the county gentry. The leadership of the forces of the 


\section{DEVELOPMENT OF HUNGARIAN LIBERTY.}

county was entrusted to a captain chosen by the inhabitants.

The gentry had thus acquired as much power as the law could confer upon them. Yet even that was not enough. No organisation can ensure for long the rule of the weaker over the stronger. Results achieved by plucky action at a suitable moment rarely endure. An armed gentry could overawe king and magnates, but only so long as they were actually in the field. The circumstance that Szapolyai was master of the situation really told against hin, for the fact of his coveting the post of governor, and perhaps even the crown, alarmed the king and prevented him from co-operating sincerely with the gentry. At heart the king was hostile to the new order. Probably even when he acquiesced in it he resolved to overthrow it at the first opportunity, and this was naturally the desire of the magnates also. Had Szapolyai been made Palatine instead of Verböczy, his election might not have been so faithfully in accord with the programme of the gentry but it would have made a stronger government possible.

Szapolyai's palatinate would have been in harmony with the traditions of that office. He had influence, enormous wealth and a standing army, in fact all the conditions of power. Verbőczy, on the contrary, lacked all these. He was a legislator, a great scholar and judge, but no warrior. The chief defender of the country, the Palatine, had never taken part in a war. He represented a new type in political life and one to which a warlike people had not learned to pay obedience. His origin was not the difficulty, for the nation never paid much heed to such a consideration. The Hunyadis, Szapolyais and Kinizsis, had not sprung from distinguished families but had acquired their rank and wealth by their prowess on the battlefield before becoming the chief dignitaries of the country. But Verböczy remained his old self in his manner of living, in worldly possessions and in his pursuits. Even when Palatine he was still only a member 
of the gentry class, while those others had become magnates before filling such an exalted post. Only an iron will and the capacity for vigorous action could have enabled Verbőczy to play his part well, and these he did not possess. He was a just and supremely honest man, but no politician; a great lawyer, an excellent patriot, but not a man of action. The Palatine should have been the highest judge and the political leader of the country. Verböczy could fulfil only the first of these duties. Yet then, if ever, the country needed a commanding personality and a strong political leading.

The new constitution had been created by a revolution. Only force could bring about such an upheaval as should throw the lower elements of society to the top, and the situation could only be maintained by the expenditure of great energy.

But Verbőczy would not employ any means inconsistent with his idealistic ways of thinking and the loftiness of his aims, yet without them he could achieve nothing. What would have been the result of the French Revolution if its leaders had really acted in accordance with the principles of liberty, equality and fraternity? Could they have defended themselves against a reaction if they had not employed tyrannical methods?

As soon as the Palatine entered upon his office he saw how difficult his work would be if the Court party and the great nobles were against him. He did not attempt to intimidate them; on the contrary he followed his own inclination when he endeavoured to win their goodwill, and it is certainly problematic whether it was the part of a good patriot to stir up internal strife. Perhaps, indeed, in his soul there had occurred the same transformation as happened to many democrats in history when commencing to move in a new sphere. The contact with the Court and aristocratic circles hardly ever failed to make an impression upon them. Perhaps as Palatine, Verböczy felt that duty compelled him to erect a barrier between himself and Szapolyai, whose secret 
plans went further than he could approve, and whom he had reason to regard as the enemy of the king. In his capacity of judge also Verbőczy came into conflict with the leader and the interests of his party. Ujlaki had left a great fortune, which was a source of power. Verbőczy as judge decided that the fortune should belong not to Szapolyai but to the treasury. It is hard to say what led him to act in this manner, whether conscience or political considerations. It is certain that his conduct created antagonistic feelings in his party. Szapolyai retired in a passion to Transylvania, leaving the Palatine who had shown himself ungrateful and had hurt his interests. The gentry themselves could not recognise the Verböczy of former times. Although he was blood of their blood, yet now that he was Palatine he ignored their interests and studied those of the Court and the magnates. Yet when they chose him they had not thought it possible that he could resemble his predecessors.

The impotent behaviour of the government caused further trouble. Money was scarce. The revolutionaries had hoped to remedy this evil easily, for such men are usually optimistic. They thought it would be enough if they put an end to all connection with the bank of the Fuggers, and demanded the payment back of the stolen fortunes, when the treasury would overflow with wealth. But they were mistaken. The revolution had shaken the country's credit and the situation became worse.

The new government could only obtain loans at a ruinous rate of interest. The European rulers took the interests of the Fuggers into their own care, and the connection which the people had without due consideration severed had to be restored, although the nation did not easily see its mistake. The taxes were not collected. In the counties the officials, who depended upon the gentry, did not act strictly enough, as they were afraid of displeasing their employers. Licence reigned everywhere, and neither king nor any other authority was obeyed.

Such a state of affairs usually occurs during times 
of revolution. How could the new elements which had just come into power be expected to usher in their golden age with self-sacrifice and the payment of taxes? "They had had enough of these before. The gentry favoured a warlike policy, and the king and his counsellors only dared to cherish in secret the idea of a truce with the Turks. Yet although inclined for war the community was chary in supplying soldiers, and the elected captains were not sufficiently independent of the people to employ force. Nor could the country reckon upon the banderia of the powerful nobles, who declared that if the gentry governed without them and against them, they might defend the country without them. Verböczy tried in vain to conciliate the magnates; he could not induce them to acquiesce in a government which had been established in opposition to them. This was the tragedy of the situation. The magnates could neither be broken nor won over. The new government could not exist either with them or without them, and its fall was inevitable. The people's trust in it was shaken and they turned from it because it had failed to safeguard the interests of the country or of the party which had placed it in power. Its adversaries could not forget that it had deprived then of their power, and they made a vigorous attack upon it. Among its own adlerents some were angered by its action, and some were merely desirous of leaving the sinking ship. Others again, awakened from their illusions, tried to work for the country in other ways.

The strengthening attack and weakening defence decided the fate of Verböczy. The reactionaries made a clever use of their opportunity. The magnates saw that with their programme of 1490 and 1518 they could not defeat their adversaries, the gentry, and so they abandoned it. Their course was the more easy because their rivals were in difficulties, and so, concealing their ambitious aims, they inscribed on their banner the motto, the restoration of the royal power, and under that banner commenced their campaign. Their cause appealed to 
the majority of the people. Whereas after the death of the strong king Matthias everyone spoke of the defence of the people's rights against the royal power, now the general conviction was that the royal power should be augmented. Experience had shown that the exaggerated power of either the gentry or the magnates was equally bad. Each party was taught by its own failure that the country could only be saved by a strong government, which it was unable to form alone. The dangers threatening from without were increasing in gravity, and the nation turned once again to the monarchy for the defence of the country.

The Jagello dynasty: might have trod the same path that Matthias had pursued so successfully. They could have used the movement of the gentry for the benefit of their own policy, but they neglected the opportunity and left to Szapolyai the work they themselves should have performed. King Louis, however, possessed some political sagacity. Some years before he had tried to gain influence over the masses. What had seemed impossible then, with the intermediation of Verböczy and Szapolyai, was now accomplished in spite of those leaders.

The favour of the populace has always been inconstant. Verböczy, who had formerly been idolised, was dismissed, and in this moment of stress and danger, when the ship of state lay tossing helplessly upon a stormy sea, the nation turned instinctively to its heaven-sent guardian, the crowned king. Louis was very young. His idleness could easily be accounted for by his bad education and the influence of evil counsellors, and the people trusted that the crisis he had to pass through would elevate him.

To this sentiment we owe the last law enacted by medirval Hungary. The difficulty of direct government by unwieldy numbers was so evident that the people, excited as they were, could not fail to perceive it.

The essence of the new law was expressed by the words "the king shall freely use his rights." The ten- 


\section{LOL'IS II. (1516-1526).}

dency of former years had been to compel the king to exercise his power indirectly, through the council, but now he was emancipated from all such restrictions.

The king was acknowledged to have the right to appoint all officials, save the Palatine, who had to be elected.

The king might introduce changes even in such offices as were already filled. He might form a council from the ranks of the barons and prelates, but "besides these noblemen his majesty shall choose eight members of the gentry class who may attend the council." It was enacted that the Diet should be convened only once a year, as the expense of attending more frequently was too great a burden. Not a single clause of this law made the king's decision subject to the consent of the council. The obstacles which had long checked the free action of the monarch were intentionally destroyed.

But just when all the power had been entrusted to one hand, that of the king, and the nation was hoping great things as a result of this transformation, the disastrous battle of Mohács (1526) suddenly dashed the country's hopes to the ground. The sword of Matthias could not be wielded by Louis II. Whether a man has authority or not is not merely a matter of law, but depends primarily upon the man's own personality. Louis was not cut out for the part of a monarch and he could make no real use of his legal rights. He was brave in the battle and died for his country, but as though Fate sought to make his end consistent with his character he sank in a marsh, his weak body being unable to bear up under the weight of the armour he wore. Life had dealt hardly with Louis; it had given him an exalted position and great vocation, but had denied him the requisite strength.

In spite of party conflicts and the lack of money, the rank and file of the nation cannot be blamed for the tragic issue of the battle. The Hungarian army was a large one and it was not lacking in bravery. An account 


\section{DEVELOPMENT OF HUNGARIAN LIBERTY.}

of its deeds at Mohács might appear to savour of gasconade if reckless heroism in battle were not such a wellknown Hungarian characteristic. The cause of the disaster was the prevalent anarchy, the absence of discipline and strong leading. Whilst the Turkish army approached in one solid mass, guided by the strong will of one man, the Hungarians were disunited and the decisive battle was fought with only a quarter of their army. Contradictory and hesitating commands, and the disobedience of some of the leading officers, were bound to lead to a catastrophe.

Even at the last a better turn could have been given to events if the king had commanded his army more ably, but Louis, though entrusted with full powers, used them so little that he submitted the leadership of the army to election. I'hen battle was already imminent, and when the contending parties had humiliated one another's candidates, Archbishop Tomori was elected as leader. It could be wished that he had been obeyed when he ordered a retreat, for then the country might have been saved. It was madness to fight before Szapolyai, Frangepan and others had joined Tomori with their troops. The king himself saw the necessity for retreat but the recklessly daring warriors scorned the idea. On the battlefield as in the council chamber they regarded themselves as freeborn nobles whose consent was necessary before any step was taken. The king asked the magnates what was to be done, instead of himself deciding and commanding.

The anarchy of the age reveals itself most clearly in this event. Hungary's independence was destroyed by that pernicious blight. The nobles did not trust their leaders who had sinned much by neglecting the duties of their position, and now when the fate of Hungary depended upon the exercise of their authority their long neglect bore its bitter fruit. The soldiers sent a deputation to the king demanding that he should at once join battle. They knew that the king could be led, and they 
therefore dared to demand instant attack and the death of those who advised to the contrary. The fatal battle followed.

The monarchy had a difficult task to discharge during the Middle Ages, for the general situation was not very favourable to it. The creation of powerful kings crumbled to nothing in the hands of weak successors. Such was the case in England after Edward I., and in Hungary after Louis I. i Jecadence was stopped by the Tudors in England, and by Matthias in Hungary. Their rule was the outcome of necessity. Both Henry VIl. and Matthias were helped to the throne by a reaction against the unruly magnates. But the further development was different in the two countries.

In England, owing to many fortunate circumstances, the monarchy retained its pre-eminence without establishing absolutism. Just at the commencement of a new era, when a king who maintained a standing army could become much more oppressive than his predecessors, in England fortunately the need for a large army had ceased. Hungary, however, was not so fortunately situated, and it was necessary that the whole nation should be trained to arms. The task of Matthias was much more difficult than that of the Tudors. Peaceful years, bringing wealth and progress, enabled the Tudors to conciliate their subjects and induce them to bear their rule more easily.

Matthias, on the contrary, had to demand a standing army, to impose frequent new taxes, and to strain the strength of his people to the uttermost. The advantages of his reign were sadly counteracted by the effects of the constant wars, and when he died he left no lawful heir.

The nation accordingly resolved to free itself from his system of government. It has always been difficult to discipline the Hungarians in such a way as to preserve their self-respect. The secret of the progress of Prussia was the ability of the Hohenzollerns to discipline their people without extinguishing their primitive freshness and vigour. 
Matthias made the attempt. He knew the Hungarians and the best way to handle them, but the lifetime of one man was not long enough to achieve a lasting result. Some of his shortcomings, too, helped to prevent his work from being of a permanent character. When he died, the nation resolved that no second Matthias should rule over it, and the period of the Jagellos was really a continuation of the period before him. While in England the long rule of the Tudors prepared the way for the modern era, in Hungary the situation after the death of Matthias was still entirely mediæval. The nation was still in such a condition that weakness in the monarch might precipitate a crisis and lead to political conflicts which meant anarchy and probable annihilation. The Jagellos were not strong enough for their task, and could do nothing to stop the process of disintegration.

The magnates and the gentry carried on their contests without paying heed to the king, but neither party gained a complete victory, and the result was the impotence of the whole State.

The internal troubles were not so grave in Hungary as they were in England during the Wars of the Roses. In England, when the monarchy became weak, the welfare of the community was entirely subordinated to the selfish policy of certain powerful families, whereas in Hungary the struggle was carried on for the sake of common interests. And Hungary, in striking contrast with other countries, which have been torn with sanguinary conflicts during the reigns of weak kings, knew no civil wars under the Jagellos with the solitary exception of the peasants' rerolt.

In consequence of Hungary's geographical situation, however, the slightest fault on the part of the nation was calculated to lead to much graver consequences than much more serious faults in other lands. The circumstances amid which the Hungarians live demand that they should never forget themselves, for one false step may be enough 
to lead to a catastrophe. And this fact Hungary must ever remember.

At the time we are now dealing with the danger of Hungary's situation again manifested itself. Owing to the proximity of the 'Turks, the anarchy resulting from the king's weakness was much more dangerous to the nation than England's far more serious internal troubles were to her. The imminence of danger awoke in the Hungarian nation the desire to strengthen the royal power. After Mohács also, the many different interests of the country alike necessitated a strong monarchy. When the Arpád dynasty became extinct (1301) the situation had been very similar, and had led to King Robert Charles becoming almost an absolute monarch. After Mohács, the danger was still greater, and the question was whether the consequences would not be graver.

The leading idea of this book has been that during the Middle Ages it was only the monarchy, uniting and guiding the strength of the various elements of the nation, which could create and maintain a situation favourable to the development of constitutional life. But under the difficult circumstances of the time the monarchy could but rarely discharge its functions properly. The problem was whether, during the period of the Jagellos, the disintegration of the State had not gone so far as to destroy the fundamental conditions of autonomy. Many more ancient creations than the Hungarian constitution have perished. Many mediaeval prerogatives were destroyed by the increasing power of the monarchy. Had not perhaps the last hour of liberty struck in Hungary?

It may be well here to sum up the constitutional achievements in Hungary during the Middle Ages. Let us glance first of all at the law, as modified by the legislation towards the end of the reign of Louis II., and see if the reaction had weakened the ancient guarantees of liberty.

The laws of King Louis II. did not alter anything fundamental in the organisation of the state. They left 


\section{DEVFLOPMENT OF HUNGARIAN LIBERTY.}

the county system untouched, together with those more recent creations which had considerably extended the sphere of action of the county organisation. The county meetings, in which the gentry class was predominant, were a power superior to the royal officials. Central administration, which in the hands of Matthias had been powerful and far-reaching, gradually lost its effectiveness. If the Hungarian monarchy desired to be master, the county system had to be reformed. The county had become a strong bulwark against the central authority. It had gained a wide sphere of action in military, judicial, administrative and political matters. It imposed taxes within its own area and played an important part in the collection of the national taxes. It exerted considerable influence upon the various administrative offices. It elected the szolgabiró (sheriff), its influence was decisive in the appointment of the deputy-lieutenant, and it had considerable weight in the matter of the election of the county lieutenant. In short the county organisation had become so powerful as to be able to hinder effective gorernment, a situation bristling with danger. Absolute royal power was only possible if the whole county system could be transformed. The various administrative offices themselves, when held by independent and distinguished aristocrats, were no pillars of absolutism. The officials, according to Hungarian law, owed no blind obedience to their head, but on the contrary were looked upon as the guardians and executors of the law, which they had to defend even against the ruler. As these offices were filled by wealthy and independent members of the nobility, there was no separate bureaucracy which the king could employ against the nobles and the constitution. The central power had to recognise the traditional authority of the meetings of the Estates. It had become clear and incontestable that without their confirmation no law could be passed, and that every important matter affecting the community came within their sphere. In the law of 1526 the Estates actually empowered the king to use his sovereign 


\section{LOUIS II. (1516-1526).}

rights. Did not this mean that, if necessity should arise, they might restrict his rights again?

One powerful weapon in their hands was the exclusive right of voting the taxes. Moreover the king was obliged to convene the Diet once a year. Great influence was assured to the Estates by the fact that they elected the Palatine, the highest official of the king, who at the same time played the part of intermediary or umpire between king and people.

The supreme executive power, however, belonged to the king. The very essence of the reaction was that it ignored the reforms of the Jagello period and returned to the ancient system, under which the king was the real head of the government. This change was salutary, for all contrary efforts had proved failures, both in England and in Hungary. The reaction in favour of royalty did not imperil the freedom of the people. In England parliamentarism developed out of the royal government and it has maintained some of its original character to the present day. Parliamentarism is royal government placed under the controlling influence of the House of Commons, to which it is responsible. It may be that freedom might have been developed under different circumstances. It is not impossible that in a country so fortunately situated as England an executive authority formed by means of election would work fairly well, although not even there, nor cven at the present day, could it prove so satisfactory as one appointed by the king.

But during the Middle Ages the elective method would certainly have checked all healthy development as it must inevitably have proved a failure. The English Parliament, as early as the Middle Ages, gained a hold over the executive without claiming the right of electing it. By means of its right to impeach an obnoxious minister it was able to get rid of him, and if it were backed by the nation it could compel ministers to resign even without resorting to that right. 


\section{DEVELOPMENT OF HUNGARIAN LIBERTY.}

It was therefore impossible to govern the country against the wishes of Parliament. Its authority and its right of voting the taxes, made it to the interest of the king to dismiss unpopular counsellors and to fill their places with men approved by the people. This in time gave rise to the idea that the ministers were responsible to Parliament. When Parliament compelled a minister to resign, without dislocating the constitution, it not only met the urgent need of the moment, but also created a precedent. Such precedents gradually established parliamentarism. What at first happened exceptionally and at the cost of violent struggles, ultimately became the usual practice. Impeachment became superfluous, and an expression of mistrust took its place.

The Hungarian Estates also preserved those rights which in England created parliamentarism. At the time of the Jagello kings the national assembly had such power that it could raise its authority over the executive to the level of a system legally established. The Estates recurred to the elective method as the strongest means of exerting influence. Parliamentarism like that of England could only be developed as a result of the schooling afforded by stern necessity and experience. The king could only be resigned to it when he was made to see that his ideal of absolute government was impossible, and Parliament, on the other hand, could only be made content with partial control and indirect influence over the executive by finding that no other system worked.

Royal government under parliamentary control is a compromise which only the lessons of practical life could so sanctify and make so popular that it has become the great example of a free constitution. The Estates in Hungary, in their conceit, tried to extend their power beyond healthy limits. Ensuing events annihilated their achievements but the means they had employed remained, and these were suited to further a parliamentary development similar to that in England, though unfortunately the situation in Hungary was less farourable than in that country. 
It was the king who appointed all the ministers, but they did not become independent of the Diet, whose power made it advisable for the king to endeavour to remain at peace with it. In the year 1497 the king had dismissed the treasurer Bakács because the Diet had demanded his dismissal. The reaction of 1526 occurred within the Diet itself. It was there that Verböczy gave in his resignation and that Bathory was appointed. It is true that the new law condemned the practice of dismissing a Palatine without formal trial, but it maintained the right of depriving the Palatine of his office if he were guilty of offences involving capital punishment. At the present day such a law would make the Palatine secure in the event of accusations prompted by political antipathy, but at that time the death sentence was readily pronounced for political misdeeds. The other officials ran the same risk. If the Diet condemned an official for unfaithfulness in the discharge of his duty, it was entitled to dispose of his property, his office, and even his life.

The Hungarian civil law was a strong bulwark of national freedom at the end of the Middle Ages. No other country had a more practical constitution. It did not give the nation more rights than it could properly use, nor did it give less than the nation needed. The king received all his power from the people, and he could not therefore possibly govern for long against the people's will, but to govern the country was undeniably his right and his duty.

He was bound to act in harmony with the nobles but it was his part to lead. In the matter of civil law the Hungarians were not behind England. The germs from which parliamentarism developed in England were all present in the Hungarian constitution also. In the thirteenth century England was in advance of Hungary, but since then representatives of the Hungarian towns had gained a place among the country's legislators and the Diet had established the right to control taxation. The law of 1526 led to important changes by drawing attention to the great burden imposed upon the poorer gentry by the necessity 


\section{DEVELOPMENT OF HUNGARIAN LIBERTY.}

of attending the meetings of the Diet, for the perception of this fact brought about a reform of that assembly which made it a purely elective body. Only in two points was Hungary behind England. One was the freedom of the Hungarian nobles from taxation. As, however, they had many heary duties to perform, the defence of the country falling upon them in proportion to their wealth and rank, and as the taxes paid by the peasants fell to some extent upon the landowners, their immunity from taxation did not make the healthy derelopment of the community impossible. It would of course have been preferable that they should not have emancipated themselves from the payment of taxes. Their exalted position would not have seemed so unreasonable if they had been first in the performance of duties towards their country. Doubtless, a strong national king would have succeeded in pursuing the policy of Matthias in this respect.

The greater evil, however, was the oppression of the peasants. In England this class took up arms to free itself, but was scattered by the upper classes. Yet by the end of the Middle Ages the peasantry had become free. The economic life of England being so much more developed than that of Hungary, people began to see the advantage of free labour over compulsory labour, and this perception gradually transformed the whole organisation of society. The growing towns also contributed to the emancipation of the country people. As the men procured work in the towns, they were able to free themselves from the chains which bound them to the soil. In Hungary, undeveloped as it was economically, the disadrantages of servile labour were not so burdensome as to overcome the selfishness of the aristocracy, nor did the towns possess sufficient privileges to enable them to defend the poorer classes against the aristocrats, and the life of the towns was not bright enough to attract and keep the masses.

The oppression of the peasantry reached its highest point at a time when the monarchy was weak, because the strong kings regarded the protection of the oppressed as 


\section{LOUIS 11. (1516-1526).}

their most important right. The papal nuncio wrote before the battle of Mohács that the oppression of the peasants was a grave danger, because they would be ready to join even the Sultan if he would promise them his protection, and he added that the king did not dare stand up in their defence because he feared the aristocracy. And the nuncio was right. The danger of the Turkish invasion was aggravated by the fact that the peasants had few interests which bound them to the nobles. But a Christian king could have made better use than the Turks of this mistake on the part of the nobles, and his duty and his wisest policy was to try to win the heart of the masses.

The chief function of the monarchy was to maintain the integrity of the state. Any disagreement between the magnates and the gentry could not fail to strengthen the king's position. At the time of the Jagello kings the various elements of the nobility were separated by marked contrasts. The different classes fought for political supremacy but the division did not go to the very heart of the State and injure the national organism itself. It was during those class contests that Verböczy was laying down the principle of the unity of all classes of the nobility, from the magnates to the gentry, in his great legal work the Tripartitum.

When the magnates formed an alliance for the defence of their privileges their utmost demand was that the offices which in past time had been held by members of their class should not be given to members of the gentry unless it was impossible to find suitable men in the ranks of the magnates. They did not close their ranks and prevent the gentry from entering them, nor did they endeavour to alter the law of succession in such a way as to ensure to their families a continuance of their privileged position. The magnates did not claim any privileges from which the gentry were rigidly excluded, nor any such position as was attained at that time by the nobility in France or in Germany. Although they were in close connection with the nobles of the western states of Europe, and were 


\section{DEVELOPMENT OF HUNGARIAN LIBER'YY.}

in opposition to the gentry party, they never acted in opposition to Hungarian traditions. They must have felt that although their rank and splendour were less than those of the higher German nobles, whose fortune was indivisible and who possessed many rights which no one else could obtain, yet they were superior to these because they were the real leaders of the nation and had a great living force of public opinion behind them. At that time they only desired to be political leaders and did not seek to raise barriers against the incoming of new elements. Their great mistake was that they endeavoured to maintain by rigid laws the political influence which their forefathers had won by means of their patriotic services. In this they failed and the troubles which followed their attempt taught them the necessity of conciliating and cooperating with the gentry. It was through the false and selfish policy of a few individuals that the magnates had been opposed to those whom in former times they used to lead and who still remained one with them in heart and soul. The ties by which the magnates now attached the gentry to themselves achieved the desired end. The Diet of 1526 showed that the ancient harmony between the different elements of the dominant classes could be restored, and as soon as the leading motive of the activity of the magnates was a truly patriotic one they were able to overthrow even Verbőczy. The whole history of the age made it evident that the differences between the contending factors were a consequence of temporary fluctuations in political life and not of any deep seated antagonism. Szapolyai, the most powerful noble in Hungary, was the leader of the gentry, and Frangepan, the proudest aristocrat, who considered his family older and more distinguished than any other, was also on their side. The magnates were really less strict in the matter of a man's ancestry than the gentry. If a man rose to eminence by his merits and was inclined to side with them, they valued his alliance however obscure his origin may have been. Thomas Bakács and Szalkai, the leaders of the Court 
party, were of humble stock. Curiously enough it was the gentry who passed the law that high offices in the church were to be reserved for those who were of noble birth. When the Treasurer Szerencsés attained his elevated position in spite of his Jewish origin, the magnates found it quite natural while it gave offence to the gentry.

An ambitious gentry and a liberal minded high nobility can always agree easily. Even if occasionally the crimes of some magnates during the reign of a weak king disturbed the harmony between the different sections of the nobility, directly the political situation changed harmony was speedily restored among those who depended upon one another and whose interests were really the same.

The great shortcoming of the mediæval state organisation was that it excluded the humbler classes of the peopl from all participation in the work of government, but on the other hand that organisation was strengthened by the circumstance that the governing classes were thoroughly united among themselves, more so than in England. It is true that later events caused a great deal of disturbance. The nobility moulded itself on the pattern of the western European states, and religion also erected barriers between certain sections of the community, while the dismembered state weakened the feeling of unity, yet all this could not cancel the effect of old traditions and cleave the nation into layers of different rank. It was the salvation of the country that in times of danger the highest nobles, who lived like kings, were one in sentiment with the poorest members of the gentry. Class hatred and jealousy, which worked so much evil in other countries, could never destroy the national tradition that all the members of the noble class were one body.

At the close of the Middle Ages the Hungarian nation was not lacking in the qualities which faroured the preservation and extension of the country's freedom. But although freedom was in no danger of decay from internal causes, the external situation was very threatening, and 


\section{DEVELOPMENT OF HUNGARIAN LIBERTY.}

was likely to strengthen the reaction caused by the anarchy following the defeat at Molács. The Sultan had absolute power over his fanatical subjects. This explains the victory of that thoroughly disciplined nation over a much freer one. Should not the Hungarians have copied some parts of the governmental system of their adversaries in order to make effective defence possible?

It had become essential that the executive power should become more centralised, and therefore the Palatine's office was now a source of weakness. The king also had to secure for himself an income large enough to enable him to maintain a powerful standing army. Where would the reaction, which all felt to be necessary, stop? Was not Hungary faced by the alternatives of either becoming disinttrated like Poland through the exaggeration of the freedom of its parts, or of becoming a prey to absolutism, like Spain, whose kings found a moral ground for their autocrate in their conflicts with the lloors? It was of course possible that the reaction would not destroy the old amstitution and that the system of Mathias would prove sufficient for the preservation of the state, although we know of no instance of a nation, engaged in similar long and cruel struggles, succeeding under a constitution which gave the community such considerable privileges as those conferred by the Hungarian constitution. Perhaps the political ability of the people might have enabled them to orercome the difficulties. Transvlvania almost accomplished a similar task. She defended herself for a long time against the assaults of the Turks, and the German emperors, and maintained her independence. Her gifted princes and the great spirit of the people, made her so strong that absolutism was unnecessary. But at last even Transylvania had to fall. Her long resistance had only been made possible by the circumstance that the Turks and Germans counteracted each other, and neither could devote all their strength to the work of conquest of a country which lay far from the chief field of battle. Transylvania chose the moment for attack which was most con- 


\section{LOUIS II. (1516-1526).}

venient to her, and her strength was not kept permanently strained to the uttermost, as that of an independent Hungary would have been.

The situation in Hungary would have been very different in many respects. One thing is certain, that if the king had answered his vocation, the constitution would have entered upon critical times; its right to exist would have been weakened and powerful national sentiments and interests would have stood opposed to it. On the other hand, if the king had neglected his duty, and had tried to destroy the constitution while using his growing power for his own selfish purposes and not for the welfare of the nation, the old bulwarks of the people's liberty were still strong enough to render stubborn resistance possible. It would have been more easy to found an absolutism that was beneficial to the nation, but the people were armed against this by their political sagacity and their respect for the traclitions of freedom.

The ensuing centuries were filled with events which make up a truly wonderful history. Many of the blows which fell upon the nation were so heary that even now their effects have not entirely passed away, yet Hungary an look back upon them with pricte, for they were trials of her strength. The explanation of the survival of the Iungarians as a separate nation lies in the fact that the Habsburg dynasty, which las never identified itself with IIungarian interests and sentiments, did not enlist the nation's instinct of self-preservation upon its own side, but has ever struggled for absolute power. Consequently the Hungarians have never taken the side of the Habsburgs but have always opposed them. This was the reason of their freedom. A tenacious clinging to their independence has always been the mainspring of their action and this has saved the country from disintegration under circumstances resembling those which in other lands have led to that result. This instinct had been causally connected with the development of a free constitution during former times, and it cnabled the popular liberties to 


\section{DEVELOPMENT OF HUNGARIAN LIBERTY.}

withstand the powerful onslaught of the oligarchs. The mediaval constitution owed its origin to the authority which the sentiment of the nation gave to the monarch.

This sentiment now served in all its strength the cause of freedom. All that had previously aided constitutional development indirectly was now directly devoted to that end. The importance of this was increased by the circumstance that it happened at a time when, if the king had identified himself with the interests of the nation, his power might have grown dangerously great owing to the enthusiastic support which the nation would have given him, more dangerous in fact to the constitution than at any time during the Middle Ages.

To the instinct of self-preservation was added another force, namely Protestantism, which together with the constitution, defended the nation's independence.

The reformed religion began to spread in the year following the battle of Mohács, and as in England, it came at the right time to throw a heary weight in to the scale of freedom. The very nature of the Protestant faith made it an ally of liberty.

The history of mediaral Hungary closed amid the indications of a titanic conflict. The elements of danger were visible and so were the factors of resistance. Which side would win? Would it be the power which had for centuries been the chief representative of absolute power in Europe, or would the victory lie with the constitution, whose strength lay in its great traditions, and which had grown with the nation, as one of its vital organs, and was defended by its most powerful instincts? Only the future could show. 


\section{CHAPTER XV.}

\section{THE FOUNDATION OF THE DOMINION OF THE HABSBURGS.}

The battle of Mohács was a turning-point in the history of Hungary. For many a long year the unity of the country was destroyed. New dangers raised their heads. Whereas the nation had formerly been master of its own fate, foreign influences then grew menacingly powerful and it became increasingly probable that Hungary would be subjugated by her ally. New thoughts and feelings stirred the hearts of men, and religion became a dominant factor in politics. On the extinction of the line of Xrpád a succession of dynasties had occupied the throne, but since Mohács the crown has remained in the possession of a single family.

The country lost a vast number of her leading men in the battle. Never before had death wrought such havoc in their ranks. Yet the full effects of the defeat did not manifest themselves immediately. For a time the current of the nation's life seemed to be running in its old channels, and men turned to face the future still influenced by their old ideas and sentiments.

After the death of King Matthias the royal power had steadily declined, and this decline was attended by a weakening of the nation's life and had a marked effect upon the events of the sixteenth century. We have seen that during the entire period of the Jagello kings the country was split into two contending parties. After the battle of Mohács their conflict was renewed and one of the first results of the battle was an alteration in the relative 


\section{DEVELOPMENT OF HUNGARIAN LIBERTY.}

strengths of the two parties. Before Mohács the adherents of the king held the reins of government and the battle itself was fought chiefly by them. In the array of the counties, which belonged to the opposite party, there were many great gaps. Szapolyai, the leader of the opposition, held aloof with his army from the conflict, and as a consequence, those who fell were nearly all supporters of the king and the national party became predominant.

This circumstance could not fail to have a decisive effect upon the nation's future. The defeated royalists adopted the policy of an Austrian allianee, and a marriage was brought about which linked the Habsburgs with the Jagellos.

While Louis II. was a child, a section of the nobility had wished to choose a Regent from the Habsburg family, and had endeavoured to pass a law securing to that family the sucession. But the gentry clung enthusiastically to the idea of a national monarchy. They would have liked to raise Szapolyai to the throne on the extinction of the Jagello linc, and they passed a law prohibiting the election of any foreign king.

Thus the first consequence of the battle of Mohács was that the only effective armed force in the land was in favour of a national monarch.

The future of the nation rested with the national party. For a time at least no one dared to oppose its decisions. The only question was whether or not that party would alter its policy. Possibly, if the Turls had remained in Hungary, taking possession of some part of it, the nearness of danger might have driven its leading men to take some wise steps for their country's safety. But the Sultan quitted the crushed and humiliated country without troubling to reap the natural consequences of his victory. Like the hunter who does not pursue the stricken deer, knowing that it must surely bleed to death, Soliman the Great left the nation to perish from abandonment to its own worst impulses and shattered discipline. He knew the Hungarians would easily persuade themselves that peace would 


\section{FOUNDATION OF HABSBURG DOMINION.}

endure for a time at least, and that their nation was still capable of maintaining an independent existence. Such hopes are apt to delude a people. Men are inclined to believe what they desire, especially during a period of decay, when petty selfishness reigns supreme. The illusions which had partly caused the disaster of Hohács, were not destroyed even by that event. Men either could not or would not see that their country's very existence depended on their banishing all petty animosities and working together for her salvation.

Szapolyai pursued his own selfish purposes. His one aim was to gain for himself the crown. How different was John Hunyadi, who, in similar circumstances, after the battle of Varna, made no attempt to occupy the throme though to do so would have been easy. Mll Ilunyadi's efforts were directed to the strengthening of the soul of the nation, and the maintenance of its unity

But Szapolyai was no hero. He was not worthy to unloose the latebet of Hunyali's shoe. The gravity of the crisis had no power to induce him to put aside his personal interests; it served but to increase his ambition. Ilis country's woes called to life no sense of duty in his breast; he only saw in them an opportunity for his own advancement.

One of the greatest disadvantages of a monarchical or aristocratic regime is that political power is sometimes enonferred by inheritance upon unsuitable men. A man whose talent is not proportionate to the loftiness of his position, may easily lose control over his passions and desires.

The excesses even of senius have brought many woes upon mankind. The vast ambitions of powerful personalities, however, are but natural. They are prompted by healthy instincts and are in accordance with the sound principle that merit should attain the first rank. But the extravagant claims of a small man are unnatural and they conflict with a nation's interests and with the laws of progress.

Unfortunately, Szapolyai's ambition found a power- 
ful ally in the popular sentiments. The bulk of the nation contemplated with dread the rule of a foreigner. Many facts bear witness to the existence of considerable ill-feeling towards the "Germans." This sentiment had been called to life and fostered by the experience of centuries. It originated in the strong opposition of the Arpad kings to the hegemony of the German emperors. Ancient memories were revived now that, after some centuries, those same plans were again conceived which had formerly threatened both the equilibrium of Europe and the independence of Hungary. Charles $\mathrm{V}$. followed in the footsteps of the old German emperors. Like the Hohenstaufens, he too resolved to play a part similar to that of Charlemagne. The Habsburgs, moreover, had earned for themselves a sinister reputation in Hungary. Their conviction that the country belonged to them by right of inheritance, had caused long years of conflict. They were a source of constant anxiety to the Hungarians, who clung to the free election of their ling as the very foundation of their liberties. The unhappy reign of Ladislas $V$., the unlawful execution of Ladislas Hunyadi, and the cunning policy of the Emperor Frederick against King Matthias, had all increased the unpopularity of Hungary's formidable neighbour.

These various memories had been crystallised into short popular sayings, which passed from mouth to mouth until they were on the lips of the whole people.

Amongst the gentry, the prevalent and all-distorting party animosity had increased the hatred of foreigners, especially "Germans," and, above all, of the Habsburgs.

Szapolyai, when convening the Diet, wrote "we cannot deny the existence of men who, under the pretence of protecting and saving the country are really seeking to exterminate the race and its language." He also said that "the Cermans come in order to take revenge."

The nation had already had experience of union with foreign countries beneath a common crown, and had found therein little advantage. Its kings were often 


\section{FOUNDATION OF HABSBURG DOMINION.}

occupied with the affairs of their other dominions at a time when Hungary alone would have furnished a powerful monarch with work and anxiety enough.

The people felt they had little in common with a ruler who could not speak their tongue and whose sympathies and duties were divided amongst several countries. The one benefit which might have outweighed these disadvantages, the brotherly help, namely, of the communities with which they were linked, never accrued to them. These other nations were never sensible of any identity of interests and accordingly never gave the Hungarians any effective aid. In the glorious wars of John Hunyadi the allies contributed but a beggarly reinforcement, and at Mohács, though the danger threatened all, no troops from the monarch's other dominions were present.

The advantages of the alliance were chiefly of a negative character. Hungary was enabled to live in peace with its western neighbours. But this did not counterbalance the positive disadvantages of having a foreign ruler. Few men give much thought to dangers which, because they have been avoided, are not very evident, and the multitudes never.

Thus Szapolyai, with his party, found support in the power of the sword, in the laws, and in the general sentiments of the people, and he was duly elected king in the very year of the great battle.

The nation dreamed of reviving the glories of the times of Matthias Hunyadi. Hungary was strong enough, it was thought, to defend herself without being organically connected with her neighbours. The prevailing temper was far from being one of resignation or of submission to the Turks. There was, on the contrary, a wonderful revival of faith in the country's strength, and it was to that, more even than to party considerations, that Szapolyai owed his elevation to the throne. It was long before such a revival was seen again. 


\section{DEVELOPMENT OF HUNGARIAN LIBERTY.}

Szapolyai was king, but his mere election had not changed the political situation very much. The majority was for him, but by no means the whole nation. The old court party had not given up hope. Some magnates living near the Austrian frontier openly declared for a rival claimant, Ferdinand. Others remained silent, as open action on their part was dangerous or impossible, but they quietly waited for an opportunity of getting rid of the hated Szapolyai and of pursuing their old policy of an alliance with Sustria. Many of the waverers might doubtless have been won orer by a military success or by a skilful distribution of gifts. Several had joined Szapolyai under some such influences, and they were likely to be won back in a similar way by his opponents. If there had been in Szapolvali one spark of the greatness which alone could have justified his bold renture, he would have driven home his success by immediate activity. The prompt and vigorous use of his power was the only method by which he might have hoped to gain the adhesion of the whole nation and to compel Ferdinand to abandon his claims.

Had he convinced the Habsburgs of his desire to be their ally and his ability to defend his frontiers against the Turlis, and had he by his vigorous measures inspired them with fear, the Iustrians would probably have postponed the execution of their plans.

That was a critical time for the Habsburgs. Vast prospects opened out before them, but for that very reason they were beset with grave dangers.

The problem facing them was-should they embark on a new enterprise and lay claim to the Hungarian crown at a time when serious difficulties might assail them from other quarters, and if they were able to maintain their proud pre-eminence without the additional strength which that crown would bring?

In the course of a comparatively short time the Habsburgs had become the foremost dynasty in the world. Formerly they had owed their importance to the dubious 


\section{FOUNDATION OF HABSBURG DOMINION.}

results of the imperial elections, but since the imperial title brought them little real power, they determined to increase their territorial possessions. Charles V., the head of the family, had control of rast resources. Spain and Naples made him the first power in southern Europe. In the north-west, the great wealth and central situation of the Netherlands which he had inherited, enabled him to threaten England, France, and the German Empire. On the sea, and in the then recently discovered New World, no Christian monarch could rival him. Shortly before the battle of Mohács he had brought to a successful issue a war with France, as a conserpuence of which he was very near gaining the whole of Burgundy, as the French king, who became his prisoner, promised to cede it to him. If Charles had once obtained Burgundy, his hand could have reached from Spain, across Italy and Burgundy, to the Netherlands, and the almost unbroken line of his empire would have shut in France, separating her from Germany.

What would have become of the equilibrium of Europe, and of the ancient rights of the German Empire, and the independence of some of its constituent parts, if to this powerful group of states, dominating the south and west of Europe, there had been added Hungary and Bohemia? But this gigantic power was not yet sufficiently consolidated, and its threatening aspect roused those whom it menaced to activity.

The imperial family played the part of claimant in nearly every part of the world, but it was met everywhere with stubborn opposition. An empire's greatness usually stands in proportion to the number of its jealous foes. Even before the Hungarian throne of the Jagellos became vacant, there had been a confederacy against the Habsburgs.

In 1526 the French king, on acquiring his liberty, broke his promise to Charles, and formed an alliance at Cognac with the Pope and with Venice. England also left the party of the Emperor. Between these powers and 
Szapolyai there was a community of interests, and had he made a vigorous attack upon the Habsburgs and besought the members of the league of Cognac to aid him, he might have been successful. But he did not do this. At first he appears to have trusted to persuasion and fine speeches. He endearoured to win the friendship of the Habsburgs and spoke of the interests of Christianity, which forbade a Catholic monarch to attack Hungary while she was fighting against the Turks. The Habsburgs placed no confidence in Szapolyai, however, for they saw that he would sooner or later join the ranks of their enemies.

Szapolyai then began to negotiate with the emperor's foes, but he could not prevail upon them to turn their arms towards the east. The Duke of Bavaria, it is true, wished to dispute the right of Ferdinand to the crown of Bohemia, but he was powerless to influence the election. Szapolyai was too weak for his allies to respect his interests or comply with his wishes. It happened then, as it happened afterwards during the wars of Rákóczy, and later still, in the time of Kossuth, that the powers wished to make use of Hungary but were not ready to go out of their way to help her. She was not important enough in their eyes to modify their policy. Her stronger allies would take no part in her struggles, but they expected her to aid them in theirs. They made sure of Hungary's help against Austria, but would not defend her.

Szapolyai did not himself take the offensive. Ferdinand, accordingly, first gained the crown of Bohemia, and thus strengthened proceeded to win that of Hungary. In the year 1527 , after a very little fighting, he achieved his aim.

As the actual occupation had been preceded by corruption and armed conflict, there were many who thought that to these alone the Habsburgs owed their success. The nation, they believed, wanted Szapolyai as king, and 


\section{FOUNDATION OF HABSBURG DOIIINION.}

the sudden change in the situation was due to the selfishness of some, and the cowardice of the majority.

This, however, was not the case. Hungary was not a conquered kingdom and Ferdinand did not owe his throne to violence.

Ferdinand's enterprise was the carrying out of an old plan, at length made feasible by the turn of events. Directly it was seen that Szapolyai made no use of his opportunities the outlook became more promising for those whose way had been made easy by a train of historical events.

Those countries the possession of which Ferdinand had coveted, had previously been beneath the sceptre of one common ruler. Their gravitation towards one another was no chance impulse, but finds its explanation in the fact that they were neighbours, with very little of a natural frontier between them. Consequently it was the ruler now of this country, and now of the other, who tried to take possession of the sister country, in which he would have found little difficulty in creating a party and in exercising the functions of a monarch.

There were other interests, too, which fostered the tendency towards union. When a state is in constant danger from another, it becomes very desirable to ensure peace. It seeks an alliance, and if possible a legal union with its neighbour, as the most efficient means of doing this. The case was thus in the relations of the Habsburgs with Hungary.

The energy of the dynasty being absorbed by vital problems in very different parts of Europe, it became indispensable that they should live at peace with Hungary. That kingdom was larger and more important than their own hereditary provinces. Had there been any friction between Hungary and themselves they would not have been able to employ theit possessions in strengthening the position of the Emperor, but would have had to ask for help from the "Holy Roman Empire," so that instead 


\section{DEVELOPMENT OF HUNGARIAN LIBERTY.}

of increasing their imperial power by means of their family property, the need of defending this would have brought them under the power of the Estates.

This is why the Habsburgs had yearned for the throne of Hungary since the time of Albert I. This, too, explains the intrigues of the Emperor Frederick against King Matthias. Hungary threatened the future of the Habsburgs.

Hungary, on the other hand, was prompted by similar instincts. Since the danger of the Turk had grown so threatening, the need of establishing peace on the western frontier had been universally felt. It was for this reason that the Hungarians accepted Ladislas V. as king, and it was possibly the same consideration which strengthened the ambition of King Matthias when he endeavoured to conquer Bohemia and Austria. His ultimate aim may have been to establish peace on the west, as a preliminary to a final settlement with the Turks. If this was his aim he was disappointed, for, like the Emperor Frederick, he too had overestimated his strength, and failed in his attempt to conquer Austria and then turn his arms against the Turks.

During the period of the Jagellos, Hungary and Austria were depenclent upon one another's efforts and this circumstance led to the adoption of a more wholesome policy. Neither of the two neighbours wished to conquer the other, and it was by means of a political alliance and contracts regulating the succession that they encleavoured to ensure present peace, and constant co-operation in the future. Unfortunately, the day of this saner policy dawned too late, for Hungary had not sufficient strength left to make a profitable use in the east of the peace which she enjoyed on the west.

In this same period a fresh interest linked the two countries to one another. The Turks had become their common foe. The Sultan Soliman was at that time the rival even of Charles $V$. on the Mediterranean. The greatest Christian monarch and the leading Mussulman 


\section{FOUNDATION OF HABSBURG DOMINION.}

power could not exist peacefully side by side in Europe, for their interests clashed at all points. Across the weakened body of Hungary the hereditary dominions of the Habsburgs felt the devastating effects of the terrible Turkish wars. The security of Austria depended upon the resistance of the Croatian territories, and the Jagellos were so weak that they were glad when Ferdinand occupied the frontier fortress.

Thus are prepared the great transformations of history. Great interests, and the ambitions they arouse, work towards certain defined aims, the organisation or annihilation of empires. For a long time they have little apparent result, but the labour is not lost for it lays the foundations of the future.

When the time is ripe for some enterprise, its success is the more easy and enduring if it is the harvest of a series of efforts, rather than the lucky result of a single attempt.

When the disastrous battle of Mohács put an end to the rule of the Jagellos, the Habsburgs saw at length some result of their efforts. It must be remembered that they had for their claims a certain basis of legal right, furnished by the dynastical contracts. Noreover, they had in Hungary a party, including most of the magnates, which was devoted to their interests and looked for some reward for old services, and which hated Szapolyai. But, more important still, the interests which linked Hungary with her neighbours and which had powerfully influenced the trend of events in the past, were becoming more and more vital. The great problem which faced the Habsburgs has already been mentioned.

Situated as they were it would have been fatal to them if the kingdom of their allies, the Jagellos, had become the possession of an enemy. The Sultan, in alliance with the King of France, could easily have arrested the growth of their power, by a protectorate over Hungary. The German empire of the Austrian house could never have become strong had not the Hungarian shield 
warded off the Turkish sword. Only on that condition could the Habsburgs count on maintaining their position in Europe. Had the war between the Christian and the Mohammedan worlds been waged on the Austrian frontier, the imperial family could not have retained their preeminence. They must have ceased from the pursuit of their great aims, and have spent their strength in defensive wars. The east would have monopolised their attention and their efforts. It was in the direction of the west that all their ambitions lay, as they were fighting for ltaly and Germany, and it was necessary therefore to bind Hungary to the Austrian Empire. 'To this end there was but one sure means, the direct rule over that country.

In Hungary also, powerful interests demanded a union with Austria. What had been merely desirable while her frontier fortresses were intact, and the wars against the Turks were chiefly waged outside her borders, and while the strength of the nation was sufficient to inspire respect and to grapple with the Moslem giant, now, when all this had been changed, had become indispensable.

The Turks, after their victory, reserved Hungary for themselves, and the final reckoning was still to come. The Hungarians could never prepare for this danger if at the same time they had to defend themselres against a western foe. On the contrary, not merely the neutrality, but the positive help of Austria was necessary.

Sometimes a nation unexpectedly displays the most admirable heroism. The perception of danger nerves it to such a degree that it is able to stand when by all human calculation it should fall. But the man who leads his country into a desperate situation without real necessity is responsible for a grave crime. He is no lover of his fatherland who lightly endangers its safety. True heroism is shown not in courting danger, but in facing it when it threatens in spite of the utmost prudence.

Who can say whether or not Hungary would have fallen before the Turks, even if she had received no out- 


\section{FOUNDATION OF HABSBURG DOMINION.}

side assistance? Nevertheless, her position was so difficult and she was so much weaker than the Turks that it was her manifest duty to seek for some support. The European equilibrium, the peace of central Europe, the interests of the neighbouring German states and the safety of Hungary, demanded that a new power should arise against the Turks, on the eastern frontier of the civilised world, and accomplish the great task which for centuries the Hungarian nation had performed alone.

Of such a power the natural nucleus was the Habsburg family. With such a king as Szapolyai, whose origin was as great an impediment to his authority as was his impotence, Hungary could never draw to her aid the neighbouring countries of the sacred empire. Poor Szapolyai was not the man to alter the political map of Europe, and the nation, stricken by so many adversities, was not in a condition to achieve what it had failed of accomplishing even in more prosperous times, to extend its borders, namely, towards the west. Had the league of Cognac been victorious; if the allies had been able to procure the Bohemian and Moravian crown for the Bavarian prince, and to conquer the hereditary Austrian dominions, the great task of creating a power for the defence of eastern Europe which events had rendered necessary, could have been accomplished without the help of the Habsburgs, and even in opposition to them. But directly the position of the Habsburgs was strengthened by the accession of one part of the inheritance of the Jagellos, that family became the only likely organiser of the force which was to be the eastern bulwark of Europe.

Thus many powerful interests favoured Ferdinand's enterprise, and a great part of the Hungarian nation appreciated those interests. After so great a blow as that which the Hungarians suffered at Mohács, it usually takes a nation some time to see its way and to make a new start, especially if the country is not blest with a great man during the crisis. 


\section{DEVELOPMENT OF HUNGARIAN LIBERTY.}

Philosophers do not agree in attaching to great men the importance conceded to them by public opinion. It is true that they cannot perform miracles and their action is paralysed if in the nation itself there is no virtue, but their influence is nevertheless immense. Mediocrity may, of course, sometimes hit upon the right way, but only slowly and after much bitter experience. But to discern infallibly, at a moment of sreat peril, the right course amidst an entangled network of new and unforeseen cireumstances, to steer clear of the danger and to select the sure means to a desired end, is given but to sreat minds. Without great men a nation's course is rratic and hesitating, wers when, with proper guidance, it would bo capable of achirving great things. Those who deny the importance of the individual urge that the age itself creates the man it needs, that if some particular sreat man had not stepped forward to play his rôle another would have done so, and that if one hero had fallen his place would at once have been taken by another.

Would indeed that it were so! When has the Hungarian nation stood in sorer need of wise leaders than before the battle of Mohács, when disaster might have been averted, or after it, when genius might have healed the country's wounds and prevented one day's misfortune from throwing it back centuries? Yet the right man was nowhere to be found. When could the eyes of the people have more easily detected genius than during that epoch, when the nation was wrestling with fatal misfortunes, and the minds of all men, accustomed as they were to autonomy, were concentrated on the question of national existence, when the interests of every individual were bound up with those of his country and when adversity had stirred profoundly the heart of every patriot?

Vitality was not lacking. The fact that Hungary had preserved her life in spite of all the buffets of fortune, and also the events of later times, alike show that the race was not weak or enervated. 


\section{FOL IDATION OF HABSBLRG DOMINION.}

It was an able and vigorous people that battled with destruction. Such situations are calculated to create great men, yet no saviour appeared.

A great man is a rare gift of Providence. Mortals simply do not know what infuences create and mould him.

After the battle of Mohács Hungary had no worthy leader. The people were like sheep without a shepherd and knew not which way to take. The first impulse drove them into the arms of Szapolyai. Some joined him from deliberate conviction, others from selfish motives, but the majority were guided by their unreasoning sentiments. One of their dominant feelings was, as we hav. seen, mistrust of the Germans, and another was fear of a foreigner's ill-will. These anxieties, however, were relieved by the promises of Ferdinand. Though his house claimed the throne as a right, he appealed to the people for his election, for he was well aware that he could not achieve his aim by conquest, but must win the nation's good-will. Accordingly he confirmed the people in their rights and liberties. His promises did not proceed from generosity but from a perception of the fact that without them he conld never become the ruler of Hungary. Public opinion would nerer have supported him had the nation feared for its liberty.

One of the motives which had induced the majority to support Szapolyai was devotion to the idea of a national monarchy, but even this was not powerful enough to brace them for a persistent struggle. Mith the exception of Matthias the rulers of Hungary had been foreigners for some eenturies, and the nation was more or less reconciled to the situation. It is true that the people did not like the rule of foreigners, but their antipathy had not become such an ardent passion as to drive them to dangerous courses.

Even during the days of its strength, before it had felt the benumbing influence of a great catastrophe, the 


\section{DEVELOPMENT OF HUNGARIAN LIBERTY.}

country was not disposed to embark on a risky enterprise for the sake of a ling of Hungarian blood. Only once did the Hungarians risli everything in war for the sake of their ling, but then it was the glorious name of Hunyadi that summoned them to the battlefield.

After the battle of Mohács the idea of a national king aided Szapolyai, but it could not allay the anxieties of patriots or hinder the calculations of the selfish. The personality of Szapolyai had no power to inspire any enthusiasm. When the people elected him ling, it was partly because they hoped he would avert the danger from their western neighbour and establish peace with Austria. and partly because they believed that the great European coalition against Charles V. would crush the Habsburgs.

But in 1527 they saw clearly that they were left without help and that the most powerful Christian monarch would attack their western frontier at the very time that the Turks were threatening them on the east. This truth was plain and weighty and could be easily perceived by all.

When Ferdinand marched against Hungary, the nation realised that it would be endangering its very existence if it persisted in the demand for a national monarchy. One of the reasons for choosing Szapolyai had been that he was the only man with an armed force at his disposal, but this was all changed by the arrival of the Austrian army.

Szapolyai was not able to come to any terms with the Turks either. In common with the whole nation he pursued the traditional Christian policy, and desired to be at peace with his western neighbours. As soon, therefore, as he was attacked by the Habsburgs his position became an impossible one. Hungary could not support a simultaneous attack from all sides, and when the people saw that Austria would not leave them unhampered to repel the Turkish onset, all confidence in the Szapolyai 


\section{FOUNDATION OF HABSBURG DOMINION.}

régime was annihilated. The policy of Matthias was destroyed together with its illusions. 'That section of the nation which favoured a legal union with Austria grew bolder and more energetic. Even those who still clung to the idea of a national monarchy, and would not give their support to Ferdinand, in spite of their antipathy to Szapolyai and the pecuniary and other gifts of the Habsburgs, felt that the disunited, humiliated and conquered nation could not long hold out against the united pressure of east and west. Why risk life and fortune in a cause which was doomed to fail?

It was not the force of German arms which overcame the Hungarian resistance. The truth is that there was no serious resistance, for public opinion had veered round. The only effect of the invasion was to direct the eyes of the whole nation upon the most formidable power in the west, a power great enough to threaten the equilibrium of Europe, and to drive home the conviction that Hungary would find in that power a constant foe, unless she averted the danger by becoming its ally.

The bulk of the nation, which had often changed sides even before the battle of Mohács, changed once again, and abandoning Szapolyai, joined the army of Ferdinand.

So long as the political situation favoured the national party, and old illusions remained, the people supported Szapolyai, but with the change in the aspect of affairs public opinion changed too. The desperate condition of Hungary convinced all men of the need for a constant and intimate union with their powerful western neighbour.

Ferdinand, accordingly (1527-1564), became master of the country without encountering any strenuous resistance, and thus the Habsburg family achieved their long cherished aim. Their eastern dominions, Austria and Bohemia, were completed by the accession of a new kingdom, and the conditions of a new European great power were fulfilled. The first step had been taken towards the 


\section{DEVELOPMENT OF HUNGARIAN LABERTY.}

creation of a new and powerful bulwark of Christendom towards the east. But it was but one step. The question still remained-would the work of the Habsburgs prove solid and lasting? That depended chiefly upon the Habsburgs themselves. 
DIVISION OF THE COUNTRY.

\section{CHAPTER XVI}

\section{DIVISION OF' THE COUNTRY.}

The career of Szapolyai, and with it the fate of Hungary, reached a critical point. So far Szapolyai had declared himself one in his aims with Christendom. He spoke of the war to be wagred against the Turks, and believed that Europe would be content if he were to defend its frontiers. Is soon as he was disappointed in this respect, only two ways were open to him; either he must abdicate or else form an alliance with the Turks. It was impossible for him to contend with both Ferdinand and Soliman, and if he fought Ferdinand he must gain Soliman as an ally. Two Hungarian kings fighting eacl other, and yet pursuing an identical policy, would have been an absurd situation. Szapolyai could not adopt the policy of an alliance with the west against Ferdinand, who was necessary as a help against the Turks. That part of the nation which looked to the west for aid had to join Ferdinand, whether they liked it or not, directly he drew the sword to enforce his claims upon Hungary. No course remained for Szapolyai, therefore, but to come to terms with the Turks, and for this course he was the only suitable man. The Habsburgs might temporarily bend before the Sultan, or maintain peace with him, but directly they came into close touch with one another, clashing was inevitable. The Habsburgs aimed at being the leaders of Christendom; how then could they bow before a successor of $\mathrm{Ml}$ hammed? The "Roman Kings" could not acquiesce in the supremacy of Constantinople. They might indeed admit for a time the supremacy of the Sultan so far as 


\section{DEVELOPMENT OF HUNG.ARIAN LIBISTY'.}

Hungary was concerned, because fate seemed to decree it, but they could not surrender the independence of their other territories without striking a blow. Germany was far from the Turkish Empire and was strong enough to oppose it.

The Sultan, on the other hand, would never have been satisfied with a theoretical protectorate over Hungary if he had to respeet the independence of the other Habsburg dominions. To do this would have meant the abandonment of all thoughts of expansion in liurope, a policy not at all acceptable to the prophet's successors. Their instince was te conquer, and their final aim was Rome and Germany. They could endure no other great power in proximity to the Sultan's empire. It was possible to tolerate the existence of the more modest realm of Szapolyai. He would be content to receive his crown and all his authority from the Sultan; he would become the Sultan's vassal and adapt his policy to that of his overlord. The Sultan could safely leave him in possession of his throne without abandoning his own plans of conquest. The segment of Ilungary over which Szapolyai ruled was not necessarily an obstack in the way of the Turkish advance, but on the contrary was a bast of operations. 'The recognition of Ferdinand's rule in Hungary, and the conclusion of peace with him would have put an end to Turkish conquest, whereas the rule of Szapolyai opened the way for it.

Szapolyai desired to remain king, and seeing that the only way to avoid being exiled, or becoming a mere subject, was to contract a Turkish alliance, he resolved to pursue that policy. It is easy to understand that of the two alternatives, annihilation or a crown, he should choose the latter, but he risked losing the esteem of posterity by pursuing a policy which would only have been justifiable if the interests of the nation had necessitated it.

This action on the part of King John Szapolyai marked a turning point in the history of Hungary. The idea of an alliance with the east, so entirely opposed to all traditions, gained sround. Till then two kings had been 


\section{DIVISION OF THE COUNTRY.}

contending for the crown, but both of them stood on the same basis. Then, however, after the victories of Ferdinand, Szapolyai struck out a new course, and set up the policy of submission to the east as a rival of the policy of alliance with the west. Fate once more confronted the nation with a grave problem. The nation had to choose not merely between rival dynasties, but between the contending powers of the east and the west.

If the Habsburgs had managed to display sufficient energy, the bulk of the nation would have sided with them. The great desire of the nation was to regain that position among the European countries which it had occupied for centuries, and to which its traditions entitled it. Every one felt keenly the humiliation of the country, and remembered the glorious age of King Matthias. The memories of that age made the darkness of the present age still more sombre. The remembrance of the heroes who had died fighting the pagans was like a protestation against the new tendency. Also an alliance with the Turks jarred on the people's Christian feelings. Hungary naturally belonged to the west by its history, its civilisation, and its faith.

In addition to all this, there was the infinitely painful remembrance of the battle of Mohícs. How great was the grief and humiliation and suffering endured at the hands of the Turks which kept alive in the Hungarians the desire to free themselves entirely from the danger of Turkish invasion. How many valuable centres of the nation's civilisation, and how much wealth had been destroyed by the Turks, and how great still was the danger. Throughout the whole country no one could go to sleep without fearing that he might wake amid the crics and lamentations of his family being massacred by the Turks, or that the dawn of a new day might be darkened by the smoke rising from his ruined home.

The most powerful instincts of the people impelled then to endeavour to free themselves from their terrible situation. All that they looked for from their ling was 


\section{DEVELOPMENT OF HUNGARIAN LIBERTY.}

that he should realise his vocation as their defender. If the Habsburgs had fultilled their expectations the cause of Szapolyai would have been lest, and the nation would have joined with enthusiasm the army which undertook the defence of Hungary's integrity, of Christianity, of the prestige of the Ilungarian name, of the honour of Hunwary's women, the life and freedom of its inhabitants, its wealth, and the homes of its people. As it happened, however, events which occurred in other parts of Europe wave a different direction to the course of derelopment in Hungary. The Habsburgs did not fulfit the expectations of the people, and as a result of this disappointment the country split into two parts at a time when it was above all things necessary that the nation should be united beneath the Habsburg seeptre.

The Habsburgs had the chance of becoming entirely one with the nation, but threugh their own fault there originated in Eastern Hungary a movement against them which was destined to play a great part in the defence of Hungarian liberty.

This result was brought about as follows. Charles $V$. Was the greatest ruler of the Habsburg line, and his fortune decided the lot of all the Habsburgs in the sixteenth century. He was not king of Hungary, yet his influence was greater than that of the country's actual ruler. His power and his successes were the convincing arguments which persuaded the Hungarians to elect a Habsburg as their king. When they raised Ferdinand to the throne (15.25), they did so because they hoped to gain the support of Charles V. Ferdinand always called his brother his "roval liege." His fate, and consequently the nation's fate as well, depended upon that of Charles.

The power of Charles I., however, seemed greater than it really was. His empire had been built up by the inheritance of various territories, and not by great statebuilding achievements, and there were great contrasts within it. In Spain, only Catholic rule was possible, for the blaze of the auto-da-fé made any Protestant tendency 


\section{DIVISION OF THE COUNTRY.}

impossible. Religious fanaticism was stronger than the autocratic monarch himself. On the other hand, Germany and the Netherlands leaned naturally towards the Reformation. The two great powers whose strife was to last for centuries, joined battle during the reign of Charles $V$. The realms of Torquemada and Luther were united beneath a common ruler. In one of these dominions Charles was almost an absolute monarch, while in the other his power was checled by important rights. Beneath his supremacy there were countries independently governed, as well as powerful princes and self-governing towns. Whatever policy he adopted, Spanish or German, he could not aroid coming into conflict with the sentiments of one or other of the two realms. Moreover, he was surrounded by powerful enemies. In the west he "was threatened by France, which had lately been welded together by its kings, and which, in the consciousness of its strengti, determined to increase its territory. Fancis $1 .$, King of France, Was also prompted by a desire te measure his strength against that of Charles l., and so the. struggle for the hegemony of Europe commenced between France and the Habsburgs. On the east, the Sultan, the ally of France, threatened the empire of the west. . Ill Europe was powerfully interested in the castern problem, from whose dangers it had till then been saved by the part which Hungary had played. This made the matter vers complicated. England, the Pope, and the ltalian powers, moved to and fro between the two camps, and were alternately allies and enemies. The personality of Charles did not tend to make the situation, difficult in itself, any easier. That monarch, who had inherited a throne upon which in former times the leaders of Christendom had sat, and who possessed great dominions in all parts of the world, aimed at restoring the imperialism of Charlemagne. Between the age of Charlemagne and that of Napoleon there was perhaps no ruler with greater ambition than the frail looking Charles. By this aim of his he created new difficulties. The spirit of the age had attacked all the great 


\section{DEVELOPMEXT OF HUNGARIAN LIBERTY.}

authorities of earlier times. It had just made its onslaught upon the papalcy at the very time when Charles was dreaming of the restoration of a dignity the day for which had gone by. He wished to make the Emperor the centre of Germany and of the Christian world, although for centuries Germany had shown a entrifugal wendency, while in other parts of Europe great and independent powers had been establishing themselies.

Mthough in the proserution of his plans Charles was rool and calculating, yet his boundless ambitions were injurious to him, for his contemporaries discerned the dangerous nature of his ams. In spite of the fact that he united a strong practical sense with his fertike imagrination, and never undertook any task which was out of proportion to his strength, and that he always displayed patience and craftiness, yet the difficulty lay in his wishing to assert his will in so many matters that he was certain to be crushed beneath the weight of all his tasks and the power of his various enemies. His very end was characteristic of the man. The keen statesman saw that he could not achieve his aim, so he did not attempt to force fate, but his plans were so entirely part of himself that when he found he could no longer battle for them he considered his life useless. Rank, power, fame, had no value in his 'ves when he saw that they could not enable him to realise his ideals, so abandoning all he retired into a monastery.

For a long time Charles was entirely successful. With sreat skill he divided the power of his enemies in such a way that he could always orercome them. In religious matters he pursued the policy of toleration, and although that did not entirely satisfy either party, yet neither rose against him and often both parties helped him against the French and the Turks. The most important circumstance in its bearing upon Hungary was that he frequently turned his weapons against the French.

The power and prestige of Francis prevented Charles from becoming the indisputably first ruler in the Christian world and from restoring the outward glory of the empire 


\section{DIVISION OE THE COUNTRY.}

and its supremacy in Italy. Francis could count upon allies even in Germany, so that Charles saw that unless he crushed the power of Francis he was not safe even in his own realm. At times Charles waged war against the Mussulmans, but unfortunately for Hungary he sought a barren glory on the coasts of Africa instead of aiming a decisive blow at the Turkish power on the banks of the Danube. Not that the importance of doing this escaped his notice, for on the contrary it occupied his thoughts frequently and seriously. In the year 1514, under the walls of Paris, he planned a Turkish campaign. The French king promised assistance to his victorious adversary. Charles was to become the champion of Christianity against the infidel, and resemble Charles Martel, who had stayed the adrance of Mohammedanism. If the event had realised this expectation Hungary would certainly have joined Charles and would have freed herself from the Turkish yoke. The whole subsequent history of the country might then have been entirely different. But events just then took an unpleasant turn. The religious problem became urgent.

So far Charles had contemplated the spread of the reformed faith in a spirit of toleration, not because he believed it to be both wrong and dangerous to interfere with religious convictions, but merely because his situation did not render interference necessary. Gradually, howerer, he came to see that the whole conception of his empire would be shattered if the unity of Christendom were disturbed. As the secular head of the Christian world he had to indicate the path which the two contending parties must walk. He wished to compel the Catholic church to admit such innovations as would have pacified the protestants, and he tried to restore the character of the religious movement as a movement for reform of the church, whereas it had become a breaking away. The Pope had long refused to summon a reforming synod, but at last, in the year 1545 , Charles made his will prevail even in this matter. The Council of Trent commenced its activity just 


\section{DEVELOPMENT OF HUNGARIAN LIBERTY.}

when Charles had brought to a successful termination his "ar with Irance. If the Protestants had taken part in the Council, as Charles had asked then, the Emperor might have been able to turn his attention to the rurks, but they knew quite well that the Catholic hierarchy would come to a decision unfarorable to them. They did not believe that the Council would really permit free discussion. Charles had to compel them by force to make concessions, but he was obliged to see that during the period of toleration the Protestants had increased considerably in power.

The Turkish campaign had to be postponed. Charles had not abandoned his purpose but affairs in his own realm were pressing. The Habsburgs wished to perform what they had promised to Hungary and they intended to turn their arms against the Turks, but in their vast empire they have often been confronted by more urgent duties. What for Hungary was the one vital interest was for the Habsburgs but one of many. A few years before the events just mentioned Henry VIII. had imposed a new faith upon his people and most of them had acquiesced in it. Was it possible for Charles to achieve $A$ similar result? Hardly. When Henry interfered with the religious affairs of England, the authority of the Pope in that country had been shaken although the national antipathy to Rome had not yet become a dogmatic system.

Henry could direct the movement, but he had not to alter strong and settled convictions. Charles, however, would have had to eradicate a faith deeply rooted in the souls of his people, while the English king, in breaking away from Rome, was supported by public opinion. Another advantage for Henry lay in his only having to concern himself with the dwellers in his island kingdom, whereas Charles had to reckon with the whole of Christian Europe. He had to persuade both the Catholic world, which felt itself strong in the possession of absolute truth, and also the adherents of the new faith, who had their own dogmas concerning salvation, two powers that were absolutely hostile to one another. Even Henry's victory 


\section{DIVISION OF THE COUNTRY'.}

was not complete. Protestantism indeed spread throughout his dominions, but the old creed showed such vitality that he was unable to establish religious uniformity.

Charles could accomplish still less than Henry. His method was impracticable but it could only have been conceived by an uncommon mind. Amidst the contention of great historical powers he sought to follow an independent line of action. Had he succeeded he would have saved Europe much suffering and interminable strife.

Outward success was not lacking. He divided the forces of the Protestants and conquered them, but the religious concordat was as far off as ever and the plan he prepared was not accepted by the Pope. His victory over the Protestants at Mühlbach added a lustre to the Emperor's name greater than it had known before. From a religious point of view the victory did not bring the result desired, but it enabled Charles to make an important political advance and to dream of governing the German Empire in accordance with the Spanish system.

But in great enterprises tire final step is often the most difficult, and this was the case in the present instance. Those whom Charles had so often employed as tools joined forces against him. They saw that if he were not checked he would crush them all. France, as well as the German princes and privileged classes, the Protestants and the Pope, all turned against him, and the exhausted old Emperor was overcome by his foes and the fruit of all his efforts was destroyed. With him came to an end the power under whose protection Hungary had placed itself. The great empire was divided without having fulfilled the heart's desire of the Hungarians of an advance against the Turks.

Ferdinand, the king of Hungary, depended for his power and success entirely upon Charles. He was really a kind of German viceroy in Hungary, and could not pursue either a Hungarian or an Austrian policy, but one dictated by international considerations.

The ascent of Ferdinand to the throne of the empire 


\section{DEVELOPMENT OF HUNGARIAN LIBERTY.}

might have been expected to usher in better times for Hungary, but it did not do so for his power was really diminished and he had less time than before for Hungarian affairs. In the division of the dominions of Charles $V$. the burdens were more equally divided than the possessions. The elements of real power remained in the hands of the branch which inherited Spain. The most loyal people of the whole empire, and that which furnished the finest soldiers of the period, fell to the share of Philip Il., as did also the transatlantic mines, men and money, those two great factors of power.

Ferdinand's legacy was less valuable. The title of Emperor which he gained was a dangerous dignity. In the past several great dynasties had been exhausted by the duties expected of them, but although much was demanded from the emperors their actual rights and powers were not very great. One of the strongest nations in Europe expected its ruler to play the leading part in Christendom and to unfurl the banners of the Sacred Empire in Italy, but it did not grant him real prerogatives. Charles $V$. had tried to alter this and to make the ruler of the Germans their real master, but he had failed. Towards the end of his life the princes triumphed over him, and the empire was split into hostile factions.

There is no hatred so terrible as that of rival religionists. Political animosity may be tempered by the knowledge that its exaggeration is a crime against God and man, but what can set a limit to the ferocity of men when the very representatives of religion fan the flame in them and foster in them the belief that the persecution of another faith is pleasing to God.

This madness was tearing Germany to pieces and the Emperor had to face the colossal task of holding the empire together. In addition to the German empire, Ferdinand had Hungary on his hands, and in that country also much required to be done in order to restore it to its former importance. The emperor-king took an oath that he would defend the country's borders and reconquer the 


\section{DIVISION OF THE COUNTRY.}

provinces which had originally belonged to it. Y'et the very capital of Hungary, together with the greater part of the country, was in the hands of the enemy. Like the Emperor's crown, that of St. Stephen also brought a great title to its wearer, but little real power. The situation in the Austrian provinces and in Bohemia was not such as to give much support to the monarch. There also religious animosity prevailed and divided the people into hostile parties. The rights of the privileged classes also checked the emperor in his actions.

The Austrian provinces, resembling a mosaic in their manifold organisations derived from the Middle Ages, formed but a weak foundation for a great power. So did the kingdom of Bohemia, which was also divided into factions, although it possessed national traditions and rights.

If the Emperor was in need of aid he had to discuss the matter with the nobles of each of his provinces. Besides the German enpire and Hungary, there were twelve other powers whose consent had to be obtained, and in such cases it was not merely the indifference of the privileged classes which had to be faced, but also, since the Reformation, the marlied ill-will of the majority of them. It was difficult to obtain the imposition of a tax, yet the grandeur of the Court entailed enormous expense. The ordinary income of the crown yielded by property and tolls did not meet the ordinary expenditure.

This precarious financial situation increased the monarch's difficulties, and since the crisis which put an end to the vast ambitions of Charles V., the German branch of the Habsburgs lost his ability to take the offensive in consequence of its diminishing power, and the many cares and manifold duties claiming its time, and restricted itself to a defensive policy. Nor did it seek to take the lead in dealing with the problems of the age. It was obliged to leave religious matters in the state in which they found themselves after the victory of the Protestants in 15.5. 


\section{DEVELOPMENT OF HUNGARIAN LIBERTY.}

The dynasty could not obliterate the effects of that defeat. The very tolerance shown by the Habsburgs was a sign of their weakness. lierdinand and Maximilian oscillated between the two religious parties although with somewhat different personal simpathies, and their chief aim was to maintain internal peace. In Rome and Trent it was without their co-operation that the terrible events of the future were prepared.

The weakness of the Habsburgs was bound to make itself felt in Hungary. The great war of deliverance from the Turks, which would have brought the nation enthusiatstically to their side, had to be postponed. Their exist"nce did not depend upon whother they possessed the whole of Ilungary or not. So long as the western portion of the country was theirs to serve as a bulwark of their German empire, the foundations of their power were safe.

That was why they tried to avoid any decisive contest, for the possible loss seemed greater than the gain.

Their interests did not demand more than that the Ilungarian fortresses defending the German frontiers should remain in Christian hands, and they saw no sufticient reason for straining their strength in an attempt to retalie those parts of Hungary which were occupied by the Turks. Hungary had had several weak kings; several of her kings had been foreigners, but all alike had thrown themselves into the work of defending the country. Now for the first time, when Ferdinand ascended the throne, the nation had to encounter arave perils without their ruler, their professed defender, rendering them any assistance. Ferdinand had originally made a favorable impression upon the nation. He appeared to possess much coodwill towards Hungary, and to be a man superior to Szapolyai, more thoughful and energetic. Unfortunately he did not understand the Hungarian language, and the nation felt considerable antipathy to his family, and it was not surprising that his first popularity soon vanished when the people, who had only accepted 


\section{DIVISION OF THE COUNTRY.}

him as ruler because of the assistance they expected of him, found that he disappointed all their expectations, that he was never one in sentiment with them and that he was busy with other matters at a time when Hungary's very existence was in danger.

Ferdinand was the first Hungarian king who seemed to have more important aims than the preservation of Hungary. The sad issue of the first Turkish war (1529) when the enemy marched up to the very walls of Vienna, Ferdinand offering but a half-hearted resistance, turned the favour of many towards Johr Szapolyai.

The nation could not but doubt either the goodwill or the power of its ruler. The executive Council itself expressed its criticism in the sentence: "Hungary cannot expect deliverance from Prague."

The nobles complained bitterly. "What your Majesty may have achieved during the past four years is unknown to us, but we know that the country has not enjoyed any fruits of your Majesty's efforts." They began to demand the country's deliverance. "If your Majesty cannot accomplish this," they said, "will you be pleased to tell us so, candidly, before we perish, so that we may find means to defend ourselves and avoid the impending danger."

Later wars with the Turks also brought bitter disappointments. For example in 1566 Soliman advanced against the fortress of Szigetvár with an enormous army. The forces deputed by the German Empire to defend Hungary made not the slightest effort to relieve it. The soldiers themselves must have suffered greatly as they heard the thunder of the guns and yet were compelled to lie idle in the camp at Györ. They knew that the gallant resistance had weakened the discipline and confidence of the Turks, and that a bold and well-directed attack would probably be successful; yet the imperial and royal army looked on as mere spectators at the most heroic and most tragic event of the century, as though they did not wish to deprive posterity of the thrilling story of Zrinyi's heroism.

But however glorious this memory might be, the 
nation could but think with ineonsolable grief of the heroes who might have been saved if only the royal army had moved. The events at Szigetrir long embittered the relations between king and peeple. The memory of that sad time was deeply engraved upon the heart of the nation. which could not forget the crime of those whose cold calculations were in no way influenced by the grand and moving struggle of thr. Kringis, and who pursued theil own selfish policy careless as to the fate of their brothersin-arms.

Szigetrár was not the only instance of this callousness. Perhaps it was the mont dramatic, but wherever we turn among the events of that period we find the same conduct repeated again and again.

The leaders of the imperial army were not prompted by an ardent desire to conquer; they had not formed the high resolve to deliver the country at ang cost. Their paramount desire was to ward off the attack of the Turks from the west, their on n homes. If the heroic defenders of Konzeg, Szigetrir and Eerer could keep back the Turks, they deemed it superfuous that any. German blood should be shed. In 1.5:3 an imperial army of from eighty to ninety thousand men lay idle near lienna and moved not a finger to deliver the fortrens of K"inzeg. Which was so heroically defended by Nicholas Jurisich. Only when the Turks sent their predatory troops towards the frontiers of Austria did Hungary's ally show any signs of life.

In the year 1int. a large German army marched to. wards Buda to recapture it, but although the Turks were then weaker than their opponents, these soon returned home after a few spiritless and ill-conceived attempts.

In the following year Soliman conquered Feherrár, the large imperial army making no effort to prevent him, and when the Turkish leader retired the army dispersed without haring unsheathed a sword. It was then that the Hungarians sent their king a manifesto. "If the other subjects of your Majesty restrict their action to the defence 
of their own frontiers, we shall be obliged to take other steps in our own defence."

A still larger army was formed and placed under the command of Prince Maurice of Saxony in 1.5.2. but that also accomplished nothing. While Dobo, the defender of Eger, covered his name with undying slory, the Prince's army lay inactive near Györ, and as soon as it heard of Dobó's victory, went home again.

Every event increased the bitter experiences of the nation. Towards the end of the sixteenth century, during the reign of the Emperor Rudulf, the war against the 'Turks was prosecuted more vigorously. The armies may have been smaller, but the spirit of their leaders was more enterprising and more resolved on the deliverance of Hunsary. Several important military dignities were conferred upon Hungarians and the fire of patriotism in their hearts communicated itself to the foreign commanders also. Besides Nádasdy, Pálffy and Zrinyi, foreign leaders like Mansfeld and Schwarzenberg fought heroically for Hungary. Their victories tended to reunite the country; even Transylvania supported the western alliance and the whole nation was one in the defence of western civilisation and its own territorial integrity. Infortunately, however, these excellent results were soon destroyed by the bad government of Rudolf.

It does not appear surprising, after considering such events as those which have been mentioned, that the Habsburgs failed to win the sympathies of the Hungarians. If we remember how much the country suffered in the course of those struggles, and from bad government, as will be indicated presently, the question arises as to how it was that in spite of such bitter experiences, one part of the nation at least continued to adhere to the Habsburgs.

The reason was that the alliance with the east had proved a failure. The Turks could not beat the German armies in a decisive battle, and could not beat down the resistance of that element in Hungary which supported 
the western alliance. Their strength was exhausted by the conquest of one fortress or another. It often happened that they made incursions into that portion of the country which belonged to the Habsburgs, but after a short campaign they retired, leaving the various fortresses in the hands of their former owners.

The Sultan was therefore unable to restore the unity of the Hungarian kingrom and to make his protégé ruler over the whole country. He only increased his power in the districts bordering on his own realm, but such districts as he conquered he kept for himself and did not hand over to those who had placed themselves under his protection. Nor did he spare those portions of the country with whose owner he stood on friendly terms. Treasures and slaves were acceptable to him though they came from Transylyania. Poor Szapolyai grieved to see how his ally devastated his dominions. The Sultan regarded Hungary as his own; he chose to make a present of part of it to Szapolyai, and afterwards to his son; it was he who nominated the rulers of Transylvania, and what belonged to his servant belonged to him. It was on this ground that the Sultan oceupied the fortress of Buda. He said that he could not allow that important stronghold to be controlled by the weak hands of a woman and a child. Shortly afterwards, he claimed the territory called Temeslioz $z$ in the south of Hungary, as well as the towns of Becse and Becskerek.

How could the nation feel drawn towards such an ally? Yet the alternative policy was as bad, in fact each policy had so many drawbacks as almost to justify the other. Even the wisest men found it impossible to decide which was the right course for the country to take amid such perplexing circumstances, and oscillated between the rival policies. The mass of the people were utterly at a loss, for while the leading men were undecided public opinion could not take up any strong line.

The deadlock resulting from the measuring of 


\section{DIVISION OF THE COUNTRY.}

strengths of the two contending powers ought to have suggested to a self-respecting people that, like Brennus, they should throw their own sword into the scale and strive to carve out a future for themselves. But the many heary blows which had fallen upon the nation had diminished both its strength and its self-reliance. The people could not trust to their own powers: they were divided into parties and could not be united in the service of one leader for one common purpose. They had no Moses to lead them out of the desert in which they found themselves.

As the nation was not attached to either of the rivals by any strong sympathies, and as neither was able by his actions to convince the whole nation as to which of the: two was most desirable, the old party strife was still kept up. One party thought that after some changes in the international situation, the limperor could still help Hungary and expel the Turks. This party stood for the western alliance. Others did not dare to defy the Turks, even when assisted by the German army. They were convinced that the Turks would ultimately be vietorious, and that it would be wisest to seek their protection. These accordingly adhered to Szapolyai. Neither party, however, was inspired by that intense conviction of the wisdom of its cause which could have carried all before it, and ever since the battle of Mohaics public opinion had remained divided.

For a time one party or the other could win over the majority of the people, but as neither ally proved satisfactory the illusions concerning both were destroyed.

The parties which during the time of the Jagello kings had corresponded to class divisions among the people now arranged themselves according to districts of the country. This alteration is explained by the events which occurred. Immediately after Mohatcs the divisions remained as before, the gentry class supporting Szapolyai while the magnates followed Ferdinand. This state of affairs could not last. As soon as Szapolyai became king he could no longer identify himself solely with the interests of the 


\section{DEVELOPMENT OF IILNGARIAN LIBERTY.}

gentry. Before the battle of Mohács it was his aim, since his intrersts demanded it, to increase the ambitions of the gentry and to amend the law in such a way as to give them the decisive word in the management of the nation's affairs, hut when he was king he could not continue this poliey. Siapolyai could not hope to be master of the comntry unless he rained aldhronts among the magnates, and he therefore sought to win them over, especially such as posisesed fortressos and soldiers.

()n the other hand the Ilabsbures could not reckon on saining the crown if they were only supported by the magnates. 'They therefore tried to sain the soodwill of all clasisis.

liah party ahandoned a policy which faroured one class too exclusively. Ona sreat question absorbed all men's minds, as to whether JJungary should ally itself with the east or with the west, and this guestion was not one calculated to divide the different classes of the community. Ithen the vital guestions of the hour were the constitution of the Council or the sphere of activity of the b) iet it is (asy to understand that the classes found themsolves in opposing camps for their interests were likely to be different; but now, when the problem was where Hungary should look for support, in the west or in the east, class differences were irrelerant. Instead of social standing, it was the locality in which a man dwelt and the relievion he professed which decided to what party he would belong. If they lived in the same district and professed the same religion, magnates and gentry could have but one policy and had no reason for forming rival parties. The natural links which had always tended to unite these two classes in Hungary made themselves felt, and the magnates again became the leaders of the gentry of their own district.

Religion also played an important part in the formation of the new parties. The Protestants at first adhered to Ferdinand as they hoped more from him than from 


\section{DIVISION OF THE COLNTRY.}

Szapolyai. Nationality also had some influence, those who were of German origin naturally joining the party of Ferdinand.

But the strongest influence of all was that of locality. Those who lived in the west of Hungary favoured the western alliance, while those who lived in the east declared for the rival policy. Mthougl private interests doubtless helped to determine the policy of many, yet they were not the only motive. People scenerally believe in all sincerity that what is best for them is also good for the community.

It is not an instance of unmitigated selfishness if, at the present day, a farmer thinlis that the saluation of the country: is to be found in the flourishing of agriculture. while an artisan looks to an extension of manufacture. Nor is it surprising if the member of a noble family professes aristocratic doctrines, while a man of humble origin is a demoerat in his principles.

The cireumstances of a man's life help him to grasp) certain truths more readily than whers: his thoughts and general conception of life are alapted to his immediate environment, and he tends to regard the world only from one point of riew. It was not pure selfishness on the part of the western portions of Hungary to desire a western alliance, while the eastrern portions favoured an alliance with the Turks. Those who lived towards the west saw the power of the Germans near at hand; they knew. by personal experience the disadvantages of a war with them and it was chiefly from this danger that they desired to save the country.

As the parties formed themselves according to districts these districts gradually became separate countries. Fate, and the nation's weakness, caused the country to drift towards separation at the very time when its interests loudly called for unity. Since 15t2 the Turks had wedged themselves into the middle of the divided country and prevented the union of the two halves. When they had pene- 


\section{DEVELOPMENT OF HUNGARIAN IIBERTY.}

trated almost as far as the northern Carpathians, and had possessed themselves of the centre of the country, the military and political union of east and west Hungary was almost impossible. The two parts were no longer divided merely by a difference of policy, and their isolation demanded a separate political and military organisation. Even if they had been one in policy it would have been exceedingly difficult to carry on a united government.

This separation was made lasting by the circumstance that Transylvania had its own traditions. Even during the time of the Arpád kings it had been governed by separate chieftains (rajdas) and both socially and economically it had developed along its own lines. Geographically it formed a well-defined territory and it would probably have become a separate dukedom if Hungary had not created its admirable system of centralisation during the Middle Ages. These circumstances made Transylrania suitable soil for the new ideas which made their appearance after the battle of Mohács, and the eastern portions of Hungary naturally found in it their centre.

The development of Hungary reached a new phase. Customs, interests and duties became clearly distinguished in the two parts of the country. Till then both parties had aimed at the unity of the whole country. Even after the fall of Buda this desire for unity lived on ; but actual facts commenced to prepare men's minds for a definite division. East Hungary did not become autonomical because its inhabitants saw that the welfare of the country depended upon an alliance with the Turks, but because they learnt to love independence and because a Turkish protectorate seemed most favourable to the interests of their own part of the country.

During the sixteenth century, however, definite separation was not the declared policy of either party. It merely resulted from the fact that neither party could overcome the other, and so each established itself in that portion of the country in which it had most adherents, and 


\section{DIVISION OF THE COUNTRY.}

there seized the reins of government. The separation occurred and persisted in spite of the definite wishes of both parties and was entirely due to the general weakness of the community. 


\section{CHAPTER XVII.}

\section{EFFORTS TO RESTORE THE UNITY OF THE COLNTRY.}

One of the most interesting features of the history of Hungary during the sixteenth century was the instinctive revolt of the nation against partition. That traditional clinging to unity could not reconcile itself to the new order of things, but neither was it able to overcome the new tendency. If the nation had one persistent desire, for it was more a desire than a strong volition, it was for unity, and it would be an attractive task to deal with the attempts prompted by that honest desire. But it is not the aim of the present book to give detalled history, so we must pass over the honest though sometimes naive attempts of the nobles to establish union beneath the sceptre of whichever monarch could be of most service to the country. Nor need we dwell upon the anbitions of a few men like Perenyi and Girtti, who hoped that the nation, ignoring the two rival kings, might raise them to the throne. The activity of Martinuzzi (Friar George), however, deserves consideration, as it was he who brought the hope of union nearest to realisation.

Martinuzzi was decidedly one of the most interesting figures upon the stage of Hungarian history, and also the first distinguished statesman of the Habsburg era. He was a riddle to his contemporaries, and has remained so for posterity. But there was one thing upon which his contemporaries were all agreed, and the verdict is the same to-day, and that was that he was a man built upon a great scale. His intellect, his capacity for work, and his quickness of decision, were equally striking. He was born to 
command. Wherever he appeared he tools the lead because he was the strongest personality present. Even those who hated him had to bend before his iron will. He could persuade individuals or crowds witl equal ease, for he was master both of the language of calm deliberation and of the fiery eloquence which sways the multitude. He was great also as an administrator, and it was he who organized Szapolyai's dominions into a well-knit whole. He was a skilful general, an able financier, and a cleverperhaps too clever-diplomatist. Is he could malie people believe what he liked he imagined he could make them acquiesce in everything he did, and it was this which caused his failure. He knew men, and that was the secret of his influence over them, but he himself remained a sealed book to others. His contemporaries trembled before him, and yet his superiority was one reason why they murdered him, for those who had grounds for fearing him only felt safe when he lay dead at their feet. He had the gift of entering into the thoughts and feelings of others, and so could present his opinions to others in such a light that they could not but approve of them. He could colour his plans in such a way as to please Austria as well as the Turks, and for a long time he led both powers.

Martinuzzi's iife was full of dramatic turns, and of contests which enable us to estimate his greatness. WV will glance for a moment at one of these contests. In the year 1540, after the death of Szapolyai, all grounds for the partition of the country ceased to exist. According to the treaty of Várad (1538) the eastern kin@dom should then have passed into the hands of Ferdinand. That king accordingly sent an army to talie Buda. Among the subjects of Szapolyai the desire for union with the western kingdom had grown strong, especially as only the unity of the whole country could save them from the rule of a woman and a child. Previously Martinuzzi had championed this policy and had acted as intermediary in the matter of the treaty of Várad. His former supporter, the 


\section{DEVELOPAIENT OF HUNGARIAN LIBERTY.}

Sublime Porte, resented the conclusion of this treaty and Was angry with Martinuzzi, and with the house of Szapolyai. Martinuzzi faced all these difficulties bravely. In spite of the treaty, and of a growing public opinion, in spite of his own promises, and the wishes of the most powerful nobles, he resolved to place the crown upon the head of the infant son of Queen Isabella, and he achieved his aim, although even his most natural ally, the Queen Regent, abandoned him.

Martinuzzi was in Transylvania when the news of Szapolyai's death arrived, and he at once took vigorous action. When he found that he could not win over the Vajda (chieftain) of Transylvania, Majláth, he contented himself with a partial success. Seeing that the contest would really be decided at Buda, he concluded a truce with Majláth, and hastened thither, leaving Transyvania to its fate. This decision of his reveals the greatness of his mind. It seemed as if he were hurrying to destruction, whereas in truth only a bold step could lead to success. A commonplace man would have stayed in Transylvania, where he could have occupied a strong defensive position, yet Martinuzzi left that place, and went where all might indeed be lost, but where also all was to be gained.

He must have seen that if he could keep Buda, and those adherents of Szapolyai who lived outside Transylvania, and could win over the wavering by the election of the infant ling, his rival Majláth's triumphs in Transylvania would not be decisive. That district, shut off from the armies of Ferdinand, could easily be regained, while if the other portions of eastern Hungary were lost they could only be recaptured by means of a Turkish war on a large scale. The really dangerous rival was not Majláth, the Vajda of Transylvania, but Ferdinand. That was why Martinuzzi resolved on his daring course. He was almost captured by the enemy, and the infant king with him, but at length he reached Buda, having outstripped his foe. 


\section{EFFORTS TO RESTORE UNITY.}

He convinced the Sultan of his fidelity, and enlisted the king of Poland as his intercessor with the Habsburgs, in order to gain time to organise his defences. He restored the confidence of his diminished party, and carried through the election of the king, and when Ferdinand's armies reached Buda, the part of diplomatist and orator gave place to that of the soldier. The victorious defence of Buda was the work of Martinuzzi.

The queen-mother intrigued with the enemy, who was at the very gates of the fortress, and Martinuzzi had reason to fear treachery, but his own strong will and presence of mind defeated both the intrigues of the queen and the attacks of the besiegers. Soon the Turkish relieving forces appeared, and the infant king John Sigismund remained master of east Hungary.

We shall not pursue further the history of that war, as enough has been said to show some of Martinuzzi's characteristic features. He was a profound thinker, as well as a man of action, and discerned the foundations of a nation's strength. He might be called a social philosopher. His keen eye saw that the weakest point in the organisation of the Hungarian community was the unhappy condition of the peasant class. He made the defence of the weak one of the chief tasks of the king, and if he did not achieve all he aimed at, the fault lay with the age and not with him.

But all the qualities we have indicated are not enough to make a man truly great; for that, purity of motives and loftiness of soul are needed. Had Martinuzzi these qualities? His ambitions were remarkable; such powers as he possessed made it inevitable that he should desire to lead, but there was never anything petty in his ambition. After the death of Szapolyai, Martinuzzi offered the governorship to Perényi, although he might easily have secured it for himself, and when Perényi declined the post Martinuzzi chose colleagues to share the power with him. In order to avoid any jealousy he would not keep the dignity 


\section{DEVELOPMENT OF HLXGARIAN LIBIERTY.}

to himself, although he bore the burdens of the office alone. He received the title of cardinal with indifference, and even after that dignity was conferred upon him, continued to call himself simply the 'leasurer. It was power that he desired, and not any splendour or rank, but the question is whether he did not to some extent sacrifice the common interests for the sake of power. To find an answer to this question it is necessary to study his policy. He saw clearly enough that Hungary could only revise if the Turks were driven out and the various parts of the country were united under the protection of western and christian Europe. A mind so great as his could not be content to labour only for a fraction of the nation, therefore we must believe that he was sincere when he adrocated the unity of the nation under the Habsbures. Since the time when he had become the chief counsellor of Szapolyai (1.5:34) this idea had alwars occupied his thoughts. Fet for sixteen vears, (15it-1;ino), during which his power was supreme, he never strove to realise the idea. Why was this? The deplorable condition of the country must have shaped Martinuzzi's conception of the situation as it shaped the thoughts of all mén. He became pessimistic concerning the nation's strength. Like the rest of his fellow-countrymen he appeared to look for some outside help which should guarantee a successful issue eren without the country's co-operation. He watched the changes in the international situation keenly. He left no stone unturned to persuade Charles $V$. to commence a war on a grand scale for the relief of Hungary, and in such a war he would have joined the Emperor with all his might, but he did not believe in the possibility of the success of smaller efforts. Nil the while he remained on such a footing with the Turls that he could have thrown in his lot with them if necessary.

He carefully aroided any act that might compromise him in the eyes of Soliman. He promised to be loyal to the Sultan, paid him tribute, and repudiated entirely the 


\section{EFFORTS TO RESTORE UNITY.}

policy of a western alliance. The difference in his relations to the two powers lay in his urging the west to activity, and in trying to pacify the east. It is true that his complex personality may have urged him to this course, the keeping two doors open in case he might have to change his policy, but this alone cannot explain his conduct. There were several enterprises, which, if he had joined in them, would have certainly been successful. Many fortresses were defended against the Turks with such wonderful heroism as to show that if the whole armed force of the nation had been properly organised the greatest results could have been achieved. Martinuzzi himself could have equipped a considerable army, yet he let the opportunity go by although he knew his neutrality involved grave risks. What assurance had he that the Turks would not lay hands upon Hungary if the German arms failed to deliver her? Would he leave even so much of her territory as would allow to the Hungarian nation a precarious existence? These were no imaginary dangers. How was it then that Martinuzzi dreaded war with the Turks more than this contingency? His neutral behaviour did not even ensure peace; he could only save one part of the country from direct devastation, which, however, fell the more heavily upon the other parts. Patriotism alone could not have prompted him to avoid war, and his conduct is only explicable on the assumption that in addition to the common interests there was also private ones which influenced his action. He himself often said that he desired always to be first. Among men like Szapolyai he was easily chief, but was it certain that this would be the case if the Habsburgs were acknowledged throughout the whole of Hungary? This doubt made him hesitate, and he only served his political aim with half his heart, and readily listened to arguments for postponing a definite decision. His personal ambition urged him to remain neutral. Therefore, one can hardly call Martinuzzi truly great. One can only regret that his ambition had too great an influence upon his conduct. 


\section{DEVELOPMENT OF HUNGARIAN LIBERTY.}

'There can be no doubt, however, that he loved his country with all his ardent soul. That sentiment which is the most characteristic feature of the Hungarian nation could not but have existed, on a scale proportioned to his grand personality, in a man who united in himself the qualities of the race in their highest degree. Nartinuzzt's ardour and inexhaustible capacity for work could not have sprung from a soil which lacked truth. Centuries afterwards his personality forces upon us the conviction that his whole nature was true and sincere. His tactics may sometimes have been artful; he used the weapons of the time with more skill than others. His patriotism was beyond question, but his ambition was also great, and he thought the chief interest of his country lay in his own rule. He was easily blinded by ambition because his soul suffused it with the glow of patriotism. The dominance of a man of genius is the surest means to the public wel. fare, but the danger lies in the ease with which the conviction of his necessity strengthens in a great man's mind until he ceases to see in himself a mere means to an end, and raises himself to the level of an end.

This happened in the case of Martinuzzi. His own supremacy seemed the all-important thing, and he remained neutral because such a course seemed most likely to perpetuate his authority. He only abandoned his neutrality when his ambition rendered it adrisable to do so, and then he took action first against the Emperor, and afterwards against the Sultan.

In 1540 , as already mentioned, Martinuzzi drew his sword against Ferdinand. He was induced to take this step, so inconsistent with his usual policy, by the necessity of choosing between surrendering Transylvania to the Emperor or defending it by force of arms. His enemies, the queen-mother and the Vajda of Transylvania, were quicker than he in joining the Habsburgs, so he saw no alternative but to call in the rurks. The curious point in all this is that it was Mar- 


\section{EFFORTS TO RESTORE UNITY.}

tinuzzi himself who had most strenuously urged Charles $V$. to attack the Turks and deliver Hungary. He had failed to persuade Charles, but we cannot imagine that this failure made him so dread a war with the Turks that he preferred to call them in and assist them. Who would throw himself into a river to avoid the rain? The Turks readily took advantage of Martinuzzi's action. They came in force and soon captured Buda. This event surprised Martinuzzi himself, but if he had acted only in the interest of the country he would not have committed a fault for which he had to pay so dearly.

The other instance of Martinuzzi's abandonment of his neutral policy, occurred near the end of his career. In 1549 he most strentously advocated the reunion of the the two halves of the country. He who a few years previously had done all in his power to prevent that union, and had acted in entire opposition to the wishes of Queen Isabella, now demanded troops from Ferdinand in order that he might compel the queen to do what he had before prevented her from doing.

The reason for this change of front was the danger which threatened Martinuzzi. It frequently happens that those who constantly put off coming to a decision till a more suitable opportunity presents itself, are ultimately obliged to act at the most unfavourable moment, because then it is fate which chooses the time for action, and not themselves. It was so in this instance. The Turks had heard rumours of Martinuzzi's activity against them, and had lost confidence in him. He was in the greatest danger because the Porte began to use threats. To avoid the danger he made wonderful efforts, as vigorous as those of 1540 , when also he had to fight for his very life.

Just when everything seemed lost, one quick decision of the former Fabius Cunctator saved the situation. Scarcely had the danger passed away when once again he changed his attitude. The international situation had become less favourable to his enterprise. The Emperor 
Charles $V$. was himself in great danger, for the king of France had attacked him, and the discontented Germans also contemplated a revolution against him. Martinuzzi at once began to hope that the former state of affairs might be revived, and even in a better form than before. He desired to re-establish peace between the Sultan and Ferdinand, and to keep on such a footing with them both that if a suitable moment came he might resuscitate the plan of freeing Hungary from the Turks without jcopardising his position. This seems the only explanation which can be given of his conduct. If he had intended to hand Transylvania over to the Turlis and to lay a trap for the armies of Ferdinand, as Castaldo alleged, he should have acted differently. If he desired to play into the hands of the Sultan, why did he inform Ferdinand of his negotiations with the Turlis, and urge the king to increase his army? Moreover, why should he have wished to give the country to which he owed his own high position, to the Turks? On the contrary he must have known that if he adhered to his agreement with Ferdinand, war with the Turks was inevitable.

What then was the explanation of his constant procrastination? It could not be any shrinking from coming to a decision in the case of so resolute a man as Martinuzzi. His action was only worthy of his intellect if he earnestly desired peace with the Turks, and to persuade the two adversaries to leave Transylvania in his hands. If that was his desire then he was right in urging Ferdinand to strengthen his army, while at the same time he strove to keep that army out of Transylvania, as he wished to remain master of the situation. The same desire led him to avoid doing any injury to the Turks, for he knew that he could not realise his hopes unless he possessed the Sultan's confidence. His negotiations with the Turks could only have had a meaning if he were paving the way for his own schemes. Ferdinand could never have occupied Transylvania peacefully, for the Sultan had often told Martinuzzi 


\section{EFFORTS TO RESTORE UNITY.}

that he would not acquiesce in Ferdinand's rule there. Martinuzzi made no attempt to overcome the Sultan's objections in this respect. He merely tried to convince the Turks that they had been misinformed concerning his actions, and that his deeds had shown how faithful he had been to their interests. This fidelity would continue unabated if the Sultan would assure to him the governorship of Transylvania, and in that case he promised to send the German armies away from there. These negotiations clearly could never have resulted in the Sultan's handing Transylvania over to Ferdinand.

Martinuzzi's policy " ould probably have been successful if he had not been murdered. In spite of the desires of the two great empires between which he stood he would have been victorious. The Sultan had actually accepted. Martinuzzi's terms. After all, it was not essential for the Turks to conquer Transylvania; so long as it was not hostile to them they could feel secure. Ferdinand also saw that his interest lay in being conciliatory. Had the agree. ment with the Sultan been carried through Ferdinand must have acquiesced in the achievement of an intellect superior to his own. The peace that would ensue was more advantageous to Ferdinand than a prolongation of the war. Moreover, the Habsburgs were more willing to see Martinuzzi governor of Transylvania than the scion of a princely house, a Szapolyai. The cardinal Martinuzzi, who had already reached his three score years and ten, would not have stood in their way so much as a young prince, who might found a dynasty. But fate decided otherwise. Martinuzzi was murdered on account of some ill-founded suspicion (1551). Castaldo and Pallavicini dreaded Martinuzzi. They could never fathom his mind, and they saw that he generally purposed something other than he said. They killed him for something he had not done, but that suspicion was generated by his past deeds. It was the nemesis of his own intriguing nature that thrust the dagger into the hands of his murderers. 


\section{DEVELOPMENT OF HUNGARIAN LIBERTY.}

Martinuzzi sincerely faroured the policy of the union of the country under the Habsburgs, yet fate had placed him at the head of the opposite party. His mind became a prey to conflicting aims, and that steadiness of purpose which is necessary for the accomplishment of great enterprises, was destroyed.

In consequence of his long hesitation the favourable moment for the nation to rise in its own strength was allowed to pass by. It was in his time that the Turks gained a footing in Hungary, and when Martinuzzi died the last statesman on a grand scale whose ideal was the deliverance of the country, passed away.

Martinuzzi then did not answer his vocation. His intellect was keen enough to recognise the task before him, but his character was not great enough to accomplish it. Yet among his efforts were many which brought lasting benefit to the country. It was he who organised the eastern portion of the country, and brought Transylvania into close contact with Hungary.

After his death his name never became the watchword of a definite national policy. The great contrasts which his tactics showed made it impossible that he should direct the nation even from the grave, as some men have done. He could not be a second IIoses to lead the nation out of the desert, nor could he even point the way to the promised land. But he founded a school. He set a classical example of the policy of a weak nation in defending itself against two stronger contending powers. Alas, several eminent Hungarian statesmen have had to copy his tactics.

The union of the country, the way to which Martinuzzi had rendered more easy, was effected after his death, when the imperial army occupied Transylvania, an act which led to war with the Turks. The murder, however, brought no blessing, for it made unpopular the system which it initiated. The Transylvanian Estates did not wish to unite with the rest of the nation, and they refused to 


\section{EFFORTS TO RESTORE UNITY.}

bear the expense of a war commenced at such an unfavourable time. All this prepared the way for the creation of the Transylvanian dukedom, and in 1556 the Szapolyais returned to Transylrania.

Efforts were made to oppose this separation. The kings of Hungary would not part with 'Transylvania entirely, and they plotted against John Sigismund, its Duke. In 1570 the treaty of Speier established the relations between the two parts of the country upon a new foundation. By that treaty John Sigismund definitely abandoned the title of king, while retaining that of Grand Duke, and concluded an offensive and defensive alliance with Ferdinand's successor, King Maximilian. Thus the contending parties made two weak crowns out of the one strong crown of St. Stephen.

The advantage, however, lay with the Habsburgs. Their State was the true successor to that of St. Stephen, and they were recognised as kings by the whole nation. Soon John Sigismund died, and the 'Transylvanian Estates elected to the throne Stephen Bathory as their Duke (1571), though King Maximilian would have preferred Jasper Békésy, the author of the treaty of Speier. Bathory pursued the policy of his predecessor, and remained the vassal of the Sultan, although he secretly made a vow of loyalty to the king of Hungary.

The Bathorys were no rivals to the Habsburgs. Stephen Bathory was much superior to the Szapolyais as a ruler, but his ambitions, so far as Hungary was concerned, were more modest than theirs. He was attached to the idea of national unity, and while he became king of Poland (1575) he was content in Hungary with the title of Vajda. He opposed the wishes of the Habsburgs in accepting the throne of Poland, but in Hungary he recognised their supremacy.

The new political formation had not, however, yet gone through the test of the Turkish Wars. A year before the treaty of Speier a truce had been agreed to with 


\section{DEVELOPMENT OF HUNGARIAN LIBERTY.}

the Turks and while that lasted the new situation could easily be maintained. The Habsburgs respected it, as otherwise the Turks would have interfered, but what would happen when war commenced again?

In 1593 war broke out, and then a dramatic struggle followed, the leading actors in which were the Duke Sigismund Báthory, a man capable of great efforts but a prey to his shattered nerves and unaccountable caprices, Michael, the cunning Vajda of Wallachia, and the rough Italian soldier Basta.

Individual ambitions and interests brought Transylvania into a critical condition. Simultaneously with these internal rivalries the problem pressed for solution as to what attitude Transylvania should adopt towards the Turks. The final outcome was the victory of Basta and his policy of uniting Transylvania with Hungary. The same century which witnessed the partition of Hungary saw its reunion. In the year 1600 all those portions of the country which were free from the Turkish yoke again recognised one sole ruler.

This union did not last long, however, for it did not meet the requirements of the eastern parts of Hungary, which had no desire to take part in the fruitless Turkish wars and wished for peace ensured by its own independent standing. How enormously important was the independence of Transylvania which followed, will be indicated in a subsequent chapter. 


\section{CHAPTER XVIII.}

\section{RELATIVE ADVANTAGES OF THE EASTERN AND WESTERN ALLIANCES.}

Ancient traditions and powerful interests equally urged the Habsburgs to endeavour to secure the Hungarian crown. The Turks, on their part, were driven by their lust of conquest to overrun Hungary. The country was accordingly threatened by the two greatest powers of the known world. Being exposed to this great danger at a time when the battle of Mohács had so diminished her strength, she had to contemplate peace and an alliance with one of those powers. All men saw this, and if there was difference of opinion it was only as to which of the two it would be wiser to join. Szapolyai's party thought that the peace and integrity of the country could only be assured by the patronage of the Turks. They hoped that if the country recognised the supremacy of the Sultan he would not seek to conquer any Hungarian territory, but would, on the contrary, give back the frontier fortresses which he had already taken. In this they were wrong. The Turks never voluntarily abandoned any territory upon which they had erected mosques. They would have considered it a slight to the Prophet and a slur upon their own supremacy to do so. Furthermore, the chief reason why they commenced war with Hungary as soon as they entered the Balkan Peninsula, was the circumstance that that country blocked the path which they must tread in order to conquer the Emperor, the first monarch of the Christian world. How could the Turks allow Hungary to regain her strength after they had conquered her at the 


\section{DEVELOPMENT OF HUNGARIAN LIBERTY.}

cost of such enormous efforts? How could they successfully attack the Emperor while a Christian State, with considerable military power, lay between them and their objective? Even if the Hungarians should allow them to pass through their territory as allies, that would not be satisfactory. The Sultans saw that they must either rule over the whole of the Danube valley or else abandon all plans of further conquest. They had indeed left Transylvania and Wrallachia to enjoy a certain amount of independence, but neither of those districts lay in their path, and they were both much weaker than Hungary. The party of Szapolyai was misled by the circumstance that for several years the Turks had not increased their dominions in Hungary, but had carried on their warfare outside it, against other countries. The fact was that after the battle of Mohács the Sultan knew that the weakened nation could not take up an aggressive attitude against him. He felt that he was practically master of Hungary and that he need not hasten to complete his conquest of the whole country. Events showed how mistaken Szapolyai had been. The Sultan took from him even Buda, and demanded the surrender of many other fortresses also. It is not surprising that the Sultan held fast the Hungarian territory which he had taken, and which was a wedge of Islam driven into the heart of Christendom, for in that territory he saw the foundation of his future European realm. He was obliged to make fresh conquests continually, because the organisation of his army demanded this. Most of the Turkish soldiers served for reward, and as a recompense for their efforts demanded a share in the land that was purchased by their blood.

The wars of the Turks against western Europe could only be carried on if one part of their army were stationed in Hungary. The fundamental conditions of the Turkish empire rendered impossible the realisation of Szapolyai's hope that the Sultan would restore Hungary's integrity. Not even peace was to be hoped for, because the lowlands 
of Hungary served as a battle ground for the Turkish army. Peace was only possible if the great struggle between the Mussulman and the Christian world terminated in the victory of the former, and the scene of the fighting were shifted to the centre of the German Empire. But how could any good Hungarian desire that? The semblance of Hungarian independence would have been worth nothing if the Crescent had shone upon the battlements of Vienna. From that moment nothing could have tempered the warlike instincts of the Turks.

The independence of Transylrania had only been permitted because the Sultan saw considerable advantage to himself in its opposition to the alliance between Hungary and Germany. So long as the prince of Transylvania fought against Hungary, he was more useful to the Sultan than a Turkish governor would have been.

Every interest of Turkey demanded the weakening and not the strengthening of Hungary. The party' opposed to Szapolyai, fully convinced of this, felt that Hungary should take up arms for Christianity against Islam. They knew that it was to Christianity that they owed their progress, and in his heart every Hungarian desired the victory of the Christian powers over the Turks. This was why they sided with the Habsburgs. After they had elected their most powerful neighbour as king they made it his duty to identify himself with the cause of Hungary, and to fight for the country's deliverance. They allied themselves with a power whose interests were identical with their own. And the alliance was calculated to achieve the expulsion of the Turks. Community of interests, of culture and of religion, bound the allies together, so that no alliance could be firmer. The wisdom of the policy is not diminished by the fact that it only met with partial success. It was not until 150 years after the battle of Mohács that Hungary was delivered from the Turkish dominion, and her deliverance was thus delayed, because the Habsburgs did not display the energy expected of them 


\section{DEVELOPMENT OF HUNGARIAN LIBERTY.}

and because certain great historical events, which were entirely unforeseen, such as the Reformation and certain national developments, operated as disturbing factors. These drew away Charles V., the most powerful of the Habsburgs, from the enterprise. The Hungarian nation itself did not exert itself as it might have done; it did not unite against the Turks, and moreover, the Habsburgs could neither satisfy nor organise the Hungarian people. The situation did not shape itself as the advocates of the western alliance had expected, yet their choice was the wisest in the circumstances, and they deserve the gratitude of posterity.

There were many who placed it to the credit of Szapolyai that the Crescent did not extend its sway over the whole of eastern Hungary. Even if they were right, it was no justification of an alliance with the Turks. It is possible that the Turlis would have pushed their conquests further in the east if Transylvania had been an adversary instead of an ally, but on the other hand they would have had less success in the west. The whole result must have been better if Transylvania had joined the Christian states. The Christian army would have been greatly augmented by this accession, for it was well-known that Martinuzzi could command an army of 100,000 men, and John Sigismund, Duke of Transylvania, one of 60,000 . One fails to understand how it could be of any advantage for this force to be idle instead of its being employed to assail the Turks from two sides. The policy adopted by Transylvania helped the Turks by so uften dividing the Hungarian forces. To give one instance, in the year of the heroic defence of Szigetvar, the king's cleverest general, Schwendi, with a great part of the army, was fighting against John Sigismund of Transylvania, instead of against the Turks. Who knows whether the Christians could not have delivered Szigetvár if only a few more men had been available?

The Hungarian-German alliance of the sixteenth 


\section{EASTERN AND WESTERN ALLIANCES.}

century did not throw all its strength into the scale against the Turks. It stopped their advance, but it did not drive them back. It was the Hungarian nation which shed the most blood in the course of the long struggle. The valour displayed by the Hungarians has rarely been surpassed. Their heroes were worthy of the renown of Leonidas. To the courage and enthusiasm of the soldiers the stemming of the tide of Turkish conquest was due. Nevertheless the nation as a whole did not display sufficient vigour; it was content to act on the defensive, and did not throw itself heartily into the work of utterly expelling the Turks, so that Hungary's neighbours uttered reproaches instead of words of appreciation. Those who had despatched great armies to foreign countries looked down upon a nation that would not equip a powerful force with the object of regaining its own territory. They forgot the enormous sacrifices the nation had already made, and regarded it as dependent upon foreign aid although the truth was that the country had defended all Europe. Hungary had given far more than she asked, and it was her undaunted courage which had exhausted the strength of the Mussulman conquerors. The king himself began to mistrust the nation, one portion of which was his constant enemy, while the other pursued a varying policy. The relations between king and people grew worse as time went on. The development of the country would have taken a different turn if the united Hungarian nation, which had saved itself almost entirely by its own efforts, could have made its voice heard in Vienna, and had nursed its strength for one great war with the Turks. Then the admiring gaze of all Europe would have been fixed upon Hungary.

But the contest between the two halves of the country largely neutralised the advantage resulting from the alliance with the west. Still, this alliance had at least the good result of counteracting the disadvantages of the Turkish alliance. Hungary was not cut off from the common interests of Europe. The fraction of the country discharged its vocation though under a terrible strain. 


\section{DEVELOPMENT OF HUNGARIAN LIBERTY.}

The Zrinyis, the Szondys, and the Dobós continued the great traditions of the Hunyadis. Their deeds adorned an age which would have been truly great if the leaders of the nation could have concentrated its strength in one channel.

It is true that the fate of a nation is largely decided by considerations of actual strength, but these are not the only matters to be borne in mind. There are certain principles which should not be riolated on any account, while any effort in accordance with them is salutary, even though it is not crowned with immediate suceess. Such a principle was the solidarity of Christendom. Even if the adhesion of Hungary to the west had entailed more risk or suffering than an alliance with the Turks, still it would have been a wiser policy, for it would have left the roots of the nation in a soil from which they could draw sustenance, while Turkey was antipathetic to the whole world to which Hungary naturally belonged. The one course would have furnished at least the hope of a national resurrection, while the Turkish alliance must have led to disaster in the event of their Turkish allies being defeated. Who can estimate the importance to Europe even to-day, of the readiness of the Hungarians to fight and to suffer in defence of Christendom?

How much less rich in noble memories Hungary would be if she had spent those years in opportunist trimming instead of straightforward action, or had pretended friendship with the Turks while seeking to betray them, waiting for the time of their downfall.

Carlyle says that Shakespeare is a more valuable possession for England than India. So, too, the glorious memory of the heroes of the sixteenth century is of greater value to Hungary than many more evident factors of her prosperity. The nation was never in doubt as to which party stood for the right cause. When Szapolyai and Ferdinand determined the frontiers of their respective realms the larger portion of the country was assigned to the former. Until the end of the sixteenth century fortune 


\section{EASTERN AND IVESTERN ALLIANCES.}

seemed to favour the Turkish arms, while the lucky star of the Habsburgs appeared to be setting. In the time of Charles V. it seemed as if that monarch would found a world-wide empire, but towards the end of the century, when Rudolf II. ruled, the Habsburg dynasty seemed nearer to its downfall than ever before in the course of its varied history. The long struggles of the Habsburgs had a weakening effect upon Hungary, while Transylvania enjoyed more peaceful times and better government, as, for example, under the rule of Martinuzzi and Stephen Báthory. Yet in spite of all this, the western kingdom had more attraction for the eastern kingdom, than the latter had for the western half of the nation, so that the union of the two portions of the country under the Habsburgs remained the nation's ideal.

The defenders of the Turkish alliance were ashamed of their policy, and felt driven to find excuses. Unfortunately, they easily found them in the attitude of the kings of Hungary, yet their souls lacked the strength born of conviction. They spoke the truth when they declared their willingness to rally round the Christian banner if only it were able to defend them. They discerned the rocation of the Hungarian people, but were not heroic enough to rise to it, and consequently the nation, though desiring unity, could not achieve it.

It was fortunate for the nation that in spite of its divided condition it could continue to exist. Life was full of hardships for the Hungarians, but they were able to survive as a people and to preserve the foundations upon which their subsequent development was based. By means of their alliance with the west they saved one part of the country from the Turks, Hungary remained a member of the western and Christian group of nations, and in spite of the independence of Transylvania, national unity was not permanently destroyed. Even the policy of Transylvania led to good results, for the strength of that district, not being exhausted by wars, was of the utmost 


\section{DEVELOPMENT OF HUNGARIAN LIBERTY.}

value to the cause of national and constitutional development.

We must now trace the influence of that period upon the liberty and the constitution of that part of Hungary which was ruled by the Habsburgs. 


\section{THE GROIVTH OF THE ROYAL POIVER.}

\section{CHAPTER XIX.}

\section{THE GROWTH OF THE ROYAL POWER.}

The Hungarian kings have always found an inexhaustible source of strength in the peop!e's instinct of selfpreservation. Amid the dangers threatening them from all sides they looked for protection to the king, and instinctively sought to strengthen his hands. From this source came the great power of the Arpád monarchs, the Angevins and Matthias. When during the Jagello period the Hungarians saw how dangerous the rule of a weak king was, the same instinct prompted them to confer the fullest powers upon the young King Louis II., who died at Mohács. After that disastrous battle the nation again longed above all things for a strong ruler. The misery which it had experienced since the death of Matthias had been due very largely to the prevailing anarchy, and the perception of this fact naturally led to a reaction in favour of the royal authority.

Fate had allotted to the Habsburgs a splendid part. Let them be real leaders and protectors of the nation, let them fight for it and with it, and then it would gladly surrender some of its rights. The military temper which the continual conflicts had developed made the people amenable to discipline. The internal condition of the country also rendered it necessary that the executive power should be strengthened. The partition of the country and the invasions of the Turks made the administration of justice practically impossible. Under such circumstances crimes sprang up like weeds. The homeless outlaws who lived by robbery, and the powerful owners of fortresses, to whom 
their money and troops assured impunity, were equally dangerous to the community. Misery and exaggerated power, the two great extremes, those who had nothing to fear for, and those who feared nothing, were equally destructive of the country's peace and order. Only a strong king could put an end to such a situation. The Habsburgs had the great advantage of being masters of other lands, so that they could draw money and troops from them, while the imporerished Hungarian community could not have prevented them from establishing an absolutist régine. The nation would have voluntarily submitted to them. But for these circumstances the Habsburges would have had to pursue a purely Hungarian policy. This they did not do, for their sole policy was that of making their own family supreme over the known world. Hungary, like their other dominions, was for them but a pawn in the game they played for the mastery of the world. This game developed itself in a manner different from their expectations. It had absorbed all their energy and attention, and the sixteenth century saw them the losers. In Hungary they were obliged to restrict themselves to defence at a time when the country looked for energetic advance. When the frontier fortresses, so essential to Hungary's defence, should have been retaken, and while the disrupted nation was longing for unity, the Habsburgs were content with merely arresting on Hungarian territory the blows which the Turks aimed at Germany.

The internal order of the country, however, underwent some improvement. Ferdinand subdued the most unruly magnates and rendered harmless some of the great robber knights. But the soldiers who effected this kept all that the robbers had stolen, and the people found their defenders more dangerous than the great nobles. Besides the fugitives from the Balkan states and Hungarian adventurers, many turbulent and badly paid Spanish, Italian, and German soldiers lived constantly in Hungary. In 


\section{THE GROWTH OF THE ROYAL POWER.}

time of war suldiers are generally violent and ready to subordinate everything to their own will. They are conscious of their own importance to the community and their exigencies are correspondingly great. Wre can easily understand that this was still more the case in the sixteenth century. To the soldiers of that day nothing was too sacred; their nature, hardened by constant killing, shrank from no deed of cruelty. When they were not properly paid or fed they plundered the country, to which they were attached by no ties.

Side by side with these were the very scum of Asia and Africa, the Turkish, Tartar, Arabian and Negro troops, who all lived by plundering, who kept slaves and saw a merit in killing Christians. Hungary was devastated by the locusts from three parts of the world. Not only did the Turks regard Hungary as a legitimate prey, but even the troops of her own ling looked upon some parts of the country in the same light. The sufferings of the people were greater than those of the nations of the Holy Roman Empire during the Thirty Years' war. As we read in the laws of that period: "the peasants have nothing but their own naked bodies, and those tortured by cruel blows." The Corpus Juris is full of bitter complaints. It is sadder to read than any tragedy, for it is a memorial of the times written with the blood and tears of a nation. Appeals were often made to the king to control his army and to place at its head Hungarian leaders who would have an interest in defending their homes. The monarchs were not deroid of goodwill, but they were unequal to their task. Their greatest difficulty was the lack of money wherewith to pay their troops.

Another great evil was the extravagance of some of their kings. Rudolf, for example, spent several millions upon his palaces and in purchasing works of art. The wealth and population of Hungary were gradually diminishing and its vitality ebbing away, and the nation laid the responsibility for this upon the king. Only by success could the monarch gain popularity among the people, but 
not one of the Hungarian Habsburgs was a great soldier. Ferdinand had never seen a battle. Maximilian clearly showed during the siege of Szigetrár that he was no general. Rudolf II. was weal, nervous, almost a lunatic, and utterly unfit for camp life. Even within the strong walls of the Bohemian king's palace of Hrasdin he trembled for his life. The Hungarians, who had been accustomed to see their kings at the head of the army, always where the danger was greatest, now never saw their monarch in a battle. While they themsetves were enduring terrible privations in the camp, they heard continually of the luxury of the Court. It was a great misfortune that the relatives of Charles $V$. had no share of his spirit. The weak and suffering body of that monarch at once became elastic and energetic as he donned his suit of mail and heard the sound of battle. He shared in the ricissitudes of war with his soldiers and frequently gare proofs of his talent as a leader. In this respect the Hungarian Habsburgs were utterly unlike him, yet though they could do nothing for the nation they endeavoured to increase their authority. Everywhere in Europe at that time the lingly power was in the ascendant. It was from that power that the cause of progress could expect the greatest support. The first condition of a nation's culture, internal peace and unity, was the rule of a strong king. The leading nations were those in which the power of the monarch had become great, namely, Turkey, France and Spain. England also owed her success in international policy to the strength of the Tudors.

In the German territories of the Habsburgs the rights of the monarch were greatly curtailed by class privileges. Of all the states beneath their sceptre, Hungary had the most highly developed constitution. The kings therefore instinctively tried to overthrow that constitution and to remore the obstacles in the way of the growth of their own power. They lessened the rights of a nation that was already dissatisfied with its rulers. They tried to achieve results which the nation would have 


\section{THE GROWWH OF THE ROYAL POIVER.}

cheerfully acquiesced in if they had but succeeded in winning its heart, but as they did not attempt to do this, king and nation never became really one. Fortunately the kings did not go too far in their demands, at least until the time of Rudolf 11 ., so that no violent collision happened until the insurrection of Bocskai (1604). It was Charles $V$. who set the example of this careful attitude. His opportunism checked his absolutist inclinations. If the nobles were willing to supply him with men and money, and did not interfere with his international policy, he did not seek to curtail their privileges. His relatives, the Hungarian kings, had still more reason to avoid any exaggeration in their claims. Ferdinand and Maximilian never endeavoured to abolish the rights of the Estates in Hungary or in their other dominions. They subordinated even their conscience in religious matters to their opportunism.

The Estates on their part showed great self-control. Under the first Habsburg rulers they did not seek to extend their constitutional rights. In view of the gravity of the country's situation all the best elements could have but one desire, namely that the executive should be strong enough to restore order. There was no party that sought to restrict the prerogatives of the crown. If the king could have won the people's hearts, he could have done what he liked with the constitution. As it was, the people did not become so strongly royalist as they might have been, yet they endured more than they would have borne under other circumstances. An opportunist king and a nation desirous of a strong government could find a modus vivendi even if there were no fundamental harmony between them, and this generally happened until the end of the sixteenth century. One great check upon the Habsburgs was the nation's right of freely electing its monarch.

In Bohemia Ferdinand used the events of 1547 to make the people " accept" his son as king without any real election. It is not surprising that he made the same 


\section{DEVELOPMENT OF HUNGARIAN LIBERTY.}

attempt in Hungary, as many of his predecessors had done. The first success achieved in this direction was in 1647 when the nation proclaimed that it would accept not only fierdinand but his deseendants as well.

In acting thus it was net deviating from the old custom which conferred a right to the crown upon the king's descendants, but an rection had always been necessary to decide which of the members of the family should asernd the throne and no coronation could take place without such an election. Ferdinand desired to remove this restriction upon his freedom of action and he so far succeceled that election was dispensed with and Maximilian was "nominated and acknowledged king" (1)(i3). Even then the coronation had to be arranged with the consent of the nobles. During the reign of Maximilian further concessions were made to the king. At the reculest of the nobles Maximilian nominated his son Rudolf as his successor, and as regards the coronation the aristocracy were only to concern themselves with its actual carrying out. If this mode of procedure became permanent the desire of the Habsburgs would be accomplished. The head of the family would always be king and there would be no need to gain rotes by clangerous concessions, while an end would be put to the harmful rivalry of the royal princes in regard to the vacant throne.

Another aim of the Habsburgs was to fill the chief executive offices with their adherents so that they might retain the power in their own hands. In 1.147 Ferdinand abolished the right of the Bohemian nobles to choose their highest officials.

In Hungary the power of the elected Palatine was a great check upon the king, who naturally disliked the office though he did not dare to suggest its abolition. Ferdinand merely induced the Estates to achnowledge that it was lawful to allow the post of Palatine to remain unfilled, and he then entrusted the duties of the office to creatures of his own appointment. 


\section{THE GROINH OF THE ROYAL POITER.}

According to Hungarian law the Palatine was the substitute of the king in his absence. This function was assigned to a nominated governor (1536 and 15t.) who also exercised most of the other rights of the Palatine. The military forces were placed under the command of an officer who was also an important member of the executive, as it was his duty to enforce judgments and to settle questions of military expenses and of recruits. The judicial duties of the Palatine were discharged by the new vice-Palatine, nominated by the king. The Estates were not pleased with this arrangement and frepuently requested the king to arrange for the election of a Palatine, but it was a proof of their conciliatory attitude that they passed laws which enabled the king to ignore their wishes. Both king and nation made concessions and thus aroided coming into collision, but the king always ananed the most as the compromise increased his power. Not only did the king gain his point in the matter of the Palatine. but he also sueceeded in making the resal council dependent upon his nomination.

It is true that in 1.536 and $1.54: 3$ the Estates made a condition that six judges of appeal should be elected by the Diet and that these judges should sit in the council according to ancient custom and should join in the discussion of certain matters, but these legal dignitaries played no greater part than had been assigned to them before the great reform movement in the time of the Jagellos. The Council was entitled to make its decisions even in their absence, and they were in no organic connection with the majority of the Estates. The functions of the royal council itself became less important, for not one of the king's decisions needed the council's consent. It wats no more than it had been in the days of Louis the Great and of Matthias, namely, a body whose duty it was to give information to the king.

The other organs of the central government were equally tools in the hands of the monarch. Financial matters were settled by a chamber organised by the king. 
The former Treasurer, who acted on his own responsibility, was replaced by a body of obedient officials. A bureaucracy began to be formed which was much more subservient to the king's wishes than the former independent dignitaries.

The most influential members of the executive were ecclesiastics. The king preferred them because the holders of impoverished benefices, who owed everything to the king, were more docile instruments than the wealthy noble's.

In 1601 , the royal council consisted of fourteen bishops and only six lay members. The governor and the chancellor were always ecclesiastics. The king frequently conferred high ecclesiastical dignities upon the sons of peasants. It was of these that Bocskay said: "being of humble origin they are naturally of a servile spirit."

Another desire of the Habsburgs was to make the taxes permanent. Such a course would no doubt have been of some advantage to the country. It was impossible to maintain a regular army, and to build towns and lieep them in good order, if the king had no definite income upon which he could reckon. But the Estates, conscious of the fact that the king was not really one with the nation, and fearing lest he should at some time turn his power against it, guarded jealously their right of controlling taxation. They made many concessions but would not surrender this peaceful means of making their influence felt. In 1545 Ferdinand, ignoring the Estates, sought the adrice of the prelates and the magnates, but as they pointed out that taxes could only be roted by the Diet he convened that assembly. Also, in the year 1558 , in accordance with the advice of the Palatine Nadasdy, the king abandoned his contention that he could order taxes to be levied even if they had not been roted.

King Maximilian saw still more clearly that he could not abolish this right of the nation. In 1.566 , when certain statesmen advised him to ask the Diet to empower him to 


\section{THE GROWTH OF THE ROY'AL POWER.}

collect such taxes as had been roted for one year, every succeeding year until the Diet was convened again, he replied that such an attempt would promote discontent and excitement.

In the year 160:3, when the proposal was made that King Rudolf should demand from the counties the money he needed, the king's Viennese Treasurer replied that this step would lead to no result, because it was not probable that all the counties would comply with the demand, and if a few refused to do so the others would withdraw their consent.

In 1559 the king asked that taxes should be roted for six years, but the Diet refused to vote them for more than one year, alleging as its reason that if the ling had a permanent income very probably he would not convene the assembly.

The ling was generally content with less than he asked for. In 1569, for example, he needed a million florins, but his German counsellors told him that he could not deal with the Hungarians as he did with the Austrians, and that as the Hungarians would probably give less than was demanded of them, the king should ask for a million and a half.

There was one other matter concerning which king and nation came into collision, and in this case too the king was the aggressor. Before the time of the Habsburgs the members of the national assembly used to appoint a few of their number to record in writing the decisions arrived at. This work was done after the members had dispersed to their homes, and those who were chosen for the task performed it in concert with the king, who had very great influence upon the result, because so much depended upon the actual wording of the acts. Moreover it sometimes happened that the members, anxious to bring the session to a close, departed without having chosen anyone for the task, which was accordingly performed by the king's own officials. 


\section{DEVELOPMENT OF HUNGARIAN LIBERTY.}

Sometimes the biet had passed resolutions eoncerning matters which the king was entitled to decide alone. Sometimes its proceedings had talien the form of a petition to the king. In all such cases the king made such alterations in the record as he thought fit, without exeeeding his rights. The Habsburgs took advantage of these precedents. Ferdinand 1. was not eeen present at the Diets of $1543,1545,1.54$ and 1.54 , nor was Maximilian present in 1566, but when, after the dissolution of the assembly, these kings did not agree with certain points in the memorandum, thes made alterations on their own authority. 'This proceeding did not have very serious conseguences as the lings never rentured to act thus in any vital matter, so the nation ratised no violent protest against their action.

Actions which had formerly been occasional autocratic illegalities on the part of the monarch, and which under different circumstances the l)iet would have gradually rendered impossible, tended to become settled custom in consequence of the nation's diminished power of resistance to encroachment upon its rights. The situation was eminently favourable to the monarch and sreatly increased his authority. He acquired more complete control orer the executive than the monarch had ever postessed before, and exercised a greater influence over legislation than was given to him by the right of sanctioning and retoing measures. 


\section{CHAPTER XX}

\section{INCREASE OF FOREIGN INFLUENCES.}

The growth of the royal power was in itself salutary for the nation, and the evils which made their appearance might not have arisen if the kings had pursued a thoroughly Hungarian policy. Unfortunately foreign influences grew stronger simultaneously with the increase of kingly authority and the independence of the country became endangered. The very power to which the nation looked for defence seemed likely to destroy it. 'There is no reason for thinking that the first Habsburer rulers wished to subordinate Hungary to their other dominions, or to form one united state of all their territories, for it was quite unlike them to sacrifice present peace for the sake of some remote aim. Nor diel they desire to Germanise Hungary. Of the first three Habsburg kings only Maximilian was German at heart. Ferdinand's mother tongue was Spanish and in all his thoughts he was nearer to Spain than to Germany. Rudolf spent his yeuth at the Court of Philip 1I. of Spain and remained entirely under Spanish influences. Germany was not pleased with these kings on account of their catholicism and consequent opposition to the new faith. If those monarchs did not pursue a German policy even in Germany itself, what was there to induce them to do so in Hungary? In that age politics were largely dominated by considerations of religion. The unity of states was secured by community of religious beliefs rather than by kinship of race.

Moreover the Habsburgs were less likely than any other rulers to identify themselves with the interests of one nation alone. They governed many peoples and a 
pronounced national character would have made their position very difficult.

Historical truth often suffers through historians attributing to the past ideas current in their own times. Ferdinand tried loyally to do his duty to Hungary. l'robably he had little love for the Hungarian constitution or the Hungarian character, and no doubt the disorganised community had few attractive features, yet in all likelihood the ling was actuated by no ill-will when he laid the foundations of the system which jeopardised the country's independence. He was probably led by a real desire to facilitate good government and to place military matters on a better footing, and it is possible that he did not altogether trust the people, whom he knew so little.

The chief cause of the increase of foreign influence was the circumstance that the struggle against the Turlis was one in which all the dominions of Ferdinand were concerned and not only Hungary. The fraction of the country which acknowledged the Habsburgs could not defend itself effectively.

The Hungarian Estates often acknowledged this and asked for foreign military aid or for money. Ferdinand's hereditary provinces voted large sums yearly for the Turkish wars. The German Empire often gave assistance, while the Pope and the Spanish relatives of the king sent money. Some Hungarian fortresses were maintained by foreign money and many of the troops, both foreigners and Hungarians, were similarly paid.

Inder the successors of Ferdinand the situation remained the same. During the sixteenth century the nonHungarian dominions of the Habsburgs contributed more money towards the expense of the war than Hungary. Foreign troops did not operate independently of the Hungarian soldiers but side by side with them. Sometimes in the same fortress there were Austrians, Germans, Hungarian royal and county troops, private troops of the great nobles, and also soldiers paid by several foreign rulers. Necessity demanded that the troops should be sent wher- 


\section{INCREASE OF FOREIGN INFLUENCES.}

ever the call for them was most urgent, and it could not be considered whether this intermingling was legally correct or not. It was also essential that these varied elements should be under a single chief, otherwise discipline would have been impossible. The rital interests at stalie made legal considerations of secondary importance. The efficient conduct of the war necessitated unity of control.

Since war had to be conducted in common, the means of war became a common concern, and accordingly the finances of the various countries had to come under common management.

Foreign affairs also became a matter in which all the Habsburg dominions were equally interested. Questions relating to the Turks, for example, were primarily Hungarian questions as they concerned IIungarian territory, but they affected Austria too since the Austrians had to bear their share of the burden of war, and such affairs could not be separated from the general liuropean policy of the Habsburgs.

Naturally, in such an entangled situation the monarch sought the advice of those whom he most trusted, and as his power and the future of his dominions were at stake, no legal scruple kept him from turning to those from whom he expected most, who were usually foreigners.

Ferdinand was a middle-aged man when he ascended the throne of Hungary. He had had his own confidants and his own principles of government, and he was then obliged to become accustomed to new ones and to share the life of a nation practically unknown to him.

The Habsburgs were used to the rigid etiquette of the Spanish Court and kept themselves aloof from their subjects, while at the Hungarian Court such stiffness was unknown.

The Hungarian kings had been powerful; their person and their exalted position had been regarded with veneration; yet they had lived the life of the nation and had not been surrounded by many formalities. Hence there was 


\section{DEVELOPMINT OI HUNGARIAN LIBERTY.}

such a contrast between the ideas of ferdinand and his Hungarian subjects as made co-operation difficult.

The llabsburg kings were often kept far from Hungary by their imperial duties. They could not go to Hungary so often as the nation would have liked, but unfortunately they were less frequently there than they might have been. If they had sacrificed some of their comfort they might have done much to win the affection of the people. As it was they never got to know them. Spending always the shortest possible time in the country, they never learnt to adapt themselves to its customs. When at long intervals, during the sittings of the Diet, they visited Hungary, they ubserved certain details in the life of the peeple to which they and their fastidious courtiers were not aceustomed.

Naturally that age so full of vicissitudes was not favourable to culture, and the people's manners were not such as were fashionable at the Escurial. Also, the political fluctuations of some of the country's statesmen, inevitable in a country so divided as Hungary then was, weakened the king's confidence in the nation. The first few years especially embittered Ferdinand. Several great nobles openly threatened to go over to the opposite party, and the liet itself passed laws which appeared to deal with such action as though it were quite pardonable. It is true that such cases of dislovalty were often due to the ling's own behariour, his impotence and the great sufferings of the people.

But what ling could see that the fault lay with himself, or could forcive disloyalty however accounted for? The Habsburgs saw in such conduct the manifestation of a spirit utterly repugnant to them, the spirit of the Golden Bull, which declared that loyalty was only obligatory upon subjects while it was beneficial to the country. This theory of conditional loyalty was abhorrent to the representative of Spanish ideas, and certainly any king's confidence would be shaken by the idea that his subjects were to judge whether he had fulfilled his duties or not. More- 
over, the policy of Martinuzzi was enough to shake the confidence of foreigners in Hungarian statesmen.

Unfortunately the king luoked unfarourably not only upon the nation's faults, but also upon its best characteristics. For example, the strong national sentiment, which was the nation's most valuable quality, and had enabled it to retain its place among the surrounding nations, awakened nothing but antipathy in the heart of the ruler. The Habsburgs governed countries which did not form an organic whole, and which had very varied interests. They could not identify themselves entirely with any one of those countries. Their one ain was to assure for themselves a position worthy of their imperial title. The crown of Hungary was to them only a means to that end, and not at all the only one or the most important one in their possession. For Hungarian politicians, on the other hand, their country was naturally the highest and final aim. They might be loyal subjects to their ling, but a great part of his interests was a matter of absolute indifference to men who cared not what influence le exerted on the Rhine or the Po. Any Hungarian frontier fortress was much more important to them. The Habsburgs judged matters of vital importance to Hungary from the point of view of their wider interests, while Hungarians judged international politics according to their influence upon Hungary. Hungarian statesmen saw that their interest lay in defending the privileges of Parliament. They constantly dwelt on constitutional rights, while it was from these constitutional rights that the king was trying his utmost to free himself. In 15.s the king declared that he was "unwilling to hear" his Hungarian subjects speak of "rights and privileges" when he asked their advice concerning the common welfare. His opinion was that men should not attach more importance to freedom than to the common good, but his Hungarian counsellors, on the other hand, could not see how the idea of the common good could be separated from that of freedom. The country had sought both freedom and prosperity under the protec- 


\section{DEVELOPMENT OF HUNGARIAN LIBERTY.}

tion of the Habsburgs, and mutual estrangement was sure to result if the king infringed the nation's laws. The Habsburg kings never treated the leading members of the Hungarian Estates as their confidential advisers, but turned for counsel to their officials in Austria or in the German Empire, who served the dynasty itself, and not this or that country. It was this class accordingly that had most influence over the monarch. Ferdinand said that it was "with consternation he heard" the Hungarians speak about "some election" when he asked them how he could have his son, and "by the grace of God his heir," crowned. Distrust grew between monarch and counsellors, and that distrust extended even to those who deserved the ruler's perfect confidence. Nicholas P'alffy, the great conqueror of the Turks, had given the most perfect proof of his loyalty, yet it was only in the company of a German councillor that the king allowed him to go and treat with the excited Estates. Very often questions arising between the king and his Hungarian counsellors were treated as though the two parties were hostile powers. An interesting case happened in the year 1.58. Rudolf II. sent the Archduke Ernest to Parliament with instructions not to come to any decision without consulting his German advisers. The instructions were superfluous, as the Archduke would have acted in that way without them, but he followed them to the letter. When the Hungarians aslied an audience of him, he first asked his German advisers whether he should grant it, and when the members of the deputation had arrived and made their requests, he sent them into an adjoining room while he discussed what answer he should give.

Even these trifling details show what a gulf existed between ruler and penple. And this mistrust operated to the disadvantage of Hungary in military matters. Military interests demanded that foreign officers should not be debarred from holding command, and that sometimes Hungarian fortresses should be garrisoned and officered by foreigners, but the monarch continually appointed for- 


\section{INCREASE OF FOREIGN INFLUENCES.}

eign officers to a far greater degree than military interests rendered necessary. This course of action could only have been prompted by his distrust of the Hungarians. Very soon these foreign officers tried to make their hold upon the Hungarian fortresses permanent. Just as in later times the Dutch tried to establish a military frontier against the French in Belgium, so the Austrians endeavoured to hold the Hungarian marches against the Turks. In these efforts they were supported by the king. Instead of standing above both parties as an impartial judge, the monarch did all in his power to help the Austrians to get the fortresses of the Hungarians into their own hands. Under cover of this attempt of the Austrians the king really sought to obtain the fulfilment of his own wishes. In 1.588 the Archduke Ernest said that " it had always been of great importance that the frontier fortresses should be held by foreigners, but in consequence of the nation's disposition this had now become doubly important." This expresses the real views of the dynasty. Its desire was that there should always be foreign armies in the country which in case of need might be used against the Hungarians themselves. As a result Hungary lost more and more of her independence, while foreign influences became predominant even in the most vital matters of the State. He who should have guarded the people's liberties strove to curtail them.

In this result the nation could not acquiesce. The Hungarians were not averse to an augmentation of the king's power, but they could not allow that power to be wielded in a hostile spirit. Resistance was inevitable, and the people saw with sorrow that danger threatened from the very quarter to which they had looked for protection. On the one hand they beheld the weapons of the Turks, while on the other hand was the danger of annexation. 


\section{DEVEIOPMEN'T OF HUNGARIAN LIBERTY.}

\section{CHAPTER XXI.}

\section{RESISTANCE TO IOOREIGN INILUENCES.}

D) against the danger of annexation only with constitutional weapons. They endearoured to ensure their independence by lecrislation. In military matters the one great aim of Hungarian legislators was to place all Hungarian fortresses, and all soldiers living in the country, whether Hungarians or foreigners, under Hungarian commanders. This aim they were unable to achieve. Those who solicit help cannot fix the conditions of that assistance, and as the Hungarians had been compelled to ask for foreign aid they could not impose the condition that their allies should only send private soldiers.

The king made such use of this farourable circumstance that in 1.536 and 15.52 he returned no answer to the nation's requests, and in 1563 he openly refused to sanction the decisions against the foreign commanders. The Estates registered the declaration, characteristic of the times, that although they must submit to this refusal, yet as the question was a vital one, they would renew their request again and again. In 1548 and 1.5.5.3 a law was passed to the effect that all foreign officials, captains of fortresses and others, were to leave Hungary, and their places to be filled by Hungarians. But the law remained a dead letter because it attempted too much, and was just as much opposed to the military interests of the country as to the wishes of the king and of the foreign allies. The king did not observe the law, even to the degree that would have been consistent with his own interests. 


\section{RESISTANCE TO FOREIGN INFLUENCES.}

From 1546 to 1563 the Estates commenced to adopt a more practical policy. Recognising the fact that they could not gain foreign military assistance and foreign money without foreign officers, they sought at least to regulate the actions of those officers. They demanded that all foreign officers should obey the orders of the Hungarian Chancellor; that in the fortresses the officers should confine themselves to the work of defence; that revenue was not to be handled by them; that they should be subject to the Hungarian judges and be dealt with according to the laws of the land; and that they should not be allowed to fix the price of provisions.

All these laws, while imposing certain restrictions upon the foreigners, indirectly acknowledged that they might be employed in Hungary. A strong effort was made to secure at least that foreign commanders should not lead Hungarian troops. Naturally this was not always feasible, as the soldiers could not always be grouped according to their nationality, but the principle was sound. Yet the king violated the principle even when it was not necessary to do so. The law ran that " the head captains of the country must be Hungarians," yet even this was not observed although to do so would not have run counter to the necessities of war. The Commander-in-Chief had been a foreigner from the very beginning. The supremacy of this "Captain-General" over the national army was acknowledged by the law of 1547 . The Hungarian Captain-General divided his command, and the Estates only imposed the condition that he should reside in the country. But in 1552 the desire arose for independent action even in connection with the common war. In that year a general mobilisation was planned, under the leadership of the king or his son. The Estates demanded that the support promised to the king should be given by Hungarian soldiers led by Hungarian officers, and that if the army should be divided, Hungarian commanders should be appointed to the Hungarian part of the army, with the same rank and powers as the foreign captains 


\section{DEVELOPMENT OF HUNGARIAN LIBERTY.}

enjoyed. The purpose of this law was to reconcile unity of command with the country's independence, but those who purposed this were not equal to the difficulties of their task, and their aim was not achieved. Strategy would have been hampered by the circumstance that the distribution of the army was connected with legal conditions, nor did the law malie the Hungarian army independent, for it did not provide that the royal council should be composed of Hungarians. As the Estates did not dare to force the king to dismiss his foreign generals, so they did not impose the condition that there should be Hungarian officers in the Council. They only decided that in case one or other of the generals should be unable to discharge his duties, a Hungarian should be appointed in his place to the command of the Hungarian troops during the war. In the following year the law was passed that on questions of war the king should seek the advice of his Hungarian Council. In 1555 the most vigorous effort was made to secure independence. The Palatine was given back his rights as Commander-in-Chief. He was placed over all the troops, both Hungarian and foreign, and the Hungarians had entire control in military matters. But this solution could not be final.

It is not right that the head of the army should be elected for life, and not be removable from his post except at the cost of grave complications. It is opposed to the principle that the ablest and most suitable men should command. It is equally opposed to the principle of the division of labour that the same man should be entrusted with military and political supremacy. Also how could the nation expect that the king would willingly trust the army which he had raised at so much expense, and with so much trouble, to a man chosen by Hungarian legislators, and would hand over his power to someone entirely independent of him? How could foreign countries be expected to supply troops again and again, if the law always subordinated them to a politician who may have given no proof of his military ability? The law never 


\section{RESISTANCE TO FOREIGN INFLUENCES.}

became really effective. A year after the king sanctioned it, he organised a permanent military Council in Vienna, and thenceforth guided himself by the opinions of that body. That foreign Council became omnipotent in Hungary, and even the Palatine could not prevent the king from acting according to its advice. The situation created in this way was sanctioned by the law of 1569 , which allowed the control of military matters to remain in the hands of the military Council in Vienna. The only influence of the Hungarians over that Council was secured by the arrangement that two Hungarian councillors, a magnate, and a prelate, should live at Court permanently in order that the king might ask their advice. The law made a clear distinction between essentially Hungarian and common affairs. Financial, military, and foreign affairs were controlled by the Court, and the councillors of the dynasty, and over these matters the Hungarians had little influence. Common affairs were not under common management, but were in the hands of an imperial Council which included no Hungarian members.

Such a situation as this, however sanctioned by law, could not be other than offensive to any nation. The Hungarians did not think it was lawful, although the Diet had permitted it, and they constantly protested against it. In the eighties there was a powerful revulsion of feelin: against the law of 1569 , and an effort was made to erase from the code the product of temporary weakness. In 1580 the Diet was dissolved without accomplishing anything, because the legislators demanded the restoration of the former freedom and of " independent government," as otherwise they were not inclined to vote any taxes, while the king would rather lose the taxes than alter the law of 1569. In 1582 and 1583 the parties drew a little nearer together. The need of money was so urgent that the king promised to restore the nation's rights, while the Estates were so conciliatory that they roted the money asked for in return for a mere promise. The king did not keep his 


\section{DEVELOPMENT OF HUNGARIAN LIBERTY.}

word, and until 1588 he governed without any revenue from taxes. At length the time came when he could no longer do without financial aid, and was obliged to convene the Diet. In the course of the discussion which followed, the king declared that his military Council in Vienna was in his eyes the supreme authority in military matters. He was not disposed to dismiss the foreign commanders, as such a step would offend the German and Austrian legislators, who had voted military assistance, and who had made it a cundition of such support that their troops should serve under their own officers. The king promised, however, that he would not slight the Hungarians, and pointed out that he had chosen several captains from their ranks. The Diet, on the other hand, demanded that the king should discuss military matters only with Hungarian councillors, and that the commanders of all troops in Hungary, including the foreign soldiers, should be Hungarians. It was quite willing that the ling should listen to the advice of foreigners also in very important matters, and that he should employ some foreigners as officers, if they were eminent soldiers. The Hungarians sought to allot to the foreigners the subordinate part which the king had intended for themselves. One party strove to make a Court affair of the common military interests of the Habsburg dominions, while the other party endeavoured to treat them as a purely Hungarian affair. After much discussion a compromise was arrived at. The nation did not sain all the influence which its legislators had claimed, but only a "due amount of power which the situation rendered necessary." The law enacted that the king or the archduke might discuss military affairs with the whole of the Hungarian council, or with such of the councillors as had to be near the king, but he was not obliged to do so. The Imperial Council was not forbidden to meddle with the Turkish wars, nor did Parliament settle anything concerning the separation of the Hungarian and the foreign troops. Common affairs were left as they had been before, except that they were placed under 
two co-ordinate authorities. These authorities were not really equal because the judge who stood above them both was not impartial. The Imperial Council was a body of military experts, while the Hungarian Council was a political body, a fact which told to its disadrantage.

The efforts of the Hungarians to secure some control in military matters took a new direction towards the end of the century, during the long war. They passed no more laws to give Hungary the leading part in military operations, but they endeavoured to define the sphere of activity of the Hungarian Council in matters outside actual warfare, such as the compulsory labour engaged in building the frontier fortresses, the provisioning of the army, and the supply of ammunition. Otherwise everything remained in 'statu quo.' Sometimes the advice of thr Hungarian Council was listened to, but the highest military authority was the Council in Vienna. The combined armies on the field of battle were under a single commander, who was either an archduke or a foreign officer. Thw Hungarian legislators were modest in their demands. They had abandoned the request that the supreme command should be given to a Hungarian, and only asked that soldiers who were paid with Hungarian money should be divided into units under Hungarian officers. A law was passed enacting that the three district commanders should be Hungarians.

The armies equipped by the country were io be led by Hungarian captains, and if they went to war they were to go in county regiments under the county banners. With regard to the Hungarian troops that were paid from the king's personal income or with foreign money, the only condition enforced was that they should be subject to Hungarian courts-martial if need should arise. The defence of the frontier fortresses might be entrusted to foreigners without reserve, Parliament abandoning its former objections in this respect. During the long wars, Hungary added several large bodies of troops to the army, and the nation would have been satisfied if their 


\section{DEVELOPMENT OF HUNGARIAN LIBER'TY.}

immediate officers had been Hungarians, yet even this result was not attained for the district captains themselves were not always Hungarians.

Especially in the northern parts of Hungary the Imperial Government dreaded Hungarian commanders, because their duty there would have been to act against Transylvania, and it would have been folly to set one Hungarian against another. It was impossible to keep all the Hungarian soldiers together, so numbers of them came directly under foreign officers.

The listates strove to aroid the joint management of foreign affairs. They demanded that negotiations should not be carried on with the Turks without consulting the Hungarian Council, because the Hungarians understood the Turks hest (1.it6). Hungary also negotiated a peace treaty with Poland in 1596. The Estates frequently demanded the restoration of all the rights of the Council, the Palatine, and the whole nation $(1536,1548,15.52,15.53$, 1.54, 1.563, 1.544, 1.588), hut the laws passed failed to secure influence to the Hungarians.

I third point for which the legislature contended was financial control. The money requisite for the Turkish wars was contributed by all the States interested, and it was handled by two bodies, the Vienna Court Treasury, and the Hungarian Treasury at Pozsony, and as the former body was in the immediate proximity of the Emperor and disposed of larger sums than the other, the supreme control gradually passed into its hands. The Hungarian Treasury, as a subservient bureaucratic body, was reconciled to this position of inferiority. The Estates, however, frequently spoke of the independence of the Hungarian Treasury (1552, 1553, 1554), and declared that all officials concerned with the revenue must be subject to that body, and take their instructions from it, and not from the Viennese Treasury. But in 1569 the king carried his point in this matter also. In 1588 the efforts at reform extended to financial matters, but the Estates were less successful here than in military affairs. The king 


\section{RESISTANCE TO FOREIGN INFLUENCES.}

was empowered to determine the limits of the activity of the Hungarian Treasury. The king was to hear the opinions of the Hungarian Council if he thought it desirable.

The canker of foreign influence affected even the most obviously internal affairs of the country. The Court Chancery had put the Hungarian Chancery into the background. The foreign body, which enjoyed the king's confidence, and was near his person, usurped the right of hearing the petitions of private persons, and of issuing orders in Hungary. The foreign soldiers and officials appealed to it even in matters relating to Hungary. In addition, several noblemen's estates which had become crown property, were given by the king to foreigners; so, too, were many county lieutenancies and bishoprics. Before the time of the Habsburgs this had been forbidden by law. The Hungarian nobles were very indignant at such action, and the kingr could not refuse to undo the wrong. The laws of several years (15336-1.258) treated of these offences, and their termination. Nevertheless, violations of the law were frequent, a state of affairs which undermined that respect for law which has ever been the strongest support of the royal authority. During those troublous times respect for the law was none too strong, and transgressors made the excuse that the king himself did not observe the laws of the land. The king set the bad example, but he himself suffered most in the end.

The sixteenth century passed away without the king and nation having become one in spirit. That century' did not bring the crisis in the nation's affairs to a head, but it fostered dissatisfaction, embittered feeling, and a sense of grievance, which were harbingers of dangerous events. The drnasty did much harm to itself as well as to the nation by its policy.

The nation's susceptibilities were cruelly hurt by the spread of foreign influence, and the efforts made to destroy the country's independence. The method of successful annexation is always to attach the people to the conquer- 


\section{DEVELOPMENT OF HUNGARIAN LIBLRTY.}

ing power by the thread of interest. Ancient Rome and Great Britain attached the inhabitants of the annexed provinees to the mother country by opening to them careers which they could not hope to enter upon as citizens of an independent country. The llabsburgs also could have employed this means, but they did not.

To the Austrian nobles the high rank of their Sovereign was adrantageous, and in time they became a real Court aristoratey. They derented themselves entirely to the Habsbure empire, and foreret their smaller fatherland. The Hungarians, on the other hand, only experienced the disadrantage of being linked to a great empire. Many advantages and posts of homeur which they had formerly enjored, were taken from them, and those which remained had diminished in importance. They had much less opportunity than before to obtain distinction and wealth. They evuld not become aburhed by the ideat of the lyabsburgs' glory or dectine, for the une object of their thoughts was Hungary.

The dymasty lost much by not striving to win the Hungarian nobles to the support of its international policy. Without counting the 'damnum emergens,' the wound inflicted upon the nation, the 'lucrum cessans' was by no means unimportant. It that time Hungary was rich in men of talent. In addition to those immortal leaders, Zrinyi, Dobi, Jurisics, and the rest, than whom no nation and no age has produced better soldiers, the country had eminent statesmen, such as Martinuzzi, Báthory, Bocskay, and Bethlen. The Batthyany, Perényis, Nádasdrs, Thurzós, and Illésházys, would have been the pride of any Court. Yet in the Council of the Hungarian king they played a subordinate part. Men of talent found scope only in Transylvania, and accordingly they all drifted thither. How much more attractive the rule of the Habsburgs would have been if they had opened to Hungarians the broad field of Europe. A system of government which does not discover and foster talent is always weak. This omission was the more disastrous as 


\section{RESISTANCE TO FOREIGN INFLLENCES.}

the Habsburgs sadly lacked eminent fellow workers. At a time when France produced the Guises, Henry IV. and Sully, and the Netherlands, William of Orange; when in England Queen Elizabeth was surrounded by such men as Burghley, Drake, and Raleigh, and Spain had a Charles V. and a Don John of Austria, the Habsburgs had not one really great statesman or soldier. It is true to a certain extent that in the wars against the Turks unity of command was essential, yet the devotion of the Hungarian nation was still more necessary. Why did not the Habsburgs give the Hungarian officials some part in the management of common concerns, or why did they not treat matters of common interest at juint meetings of the two Councils? It least they might have given some place among the Court dignitaries to eminent Hungarians. By so doing they would have alleviated the embittered feeling of the nation. It would not have been difficult for the king to organise the joint executive in such a way that its Hungarian portion consisted of men to his taste, and that the final decision always rested with himself. The sympathy of the nation could so rasily have been won. The Hungariats were grateful exen for empty phrases. In 1.593 the archduke Matthias exercised a considerable influence upon the decisions of the l)iet by the mere statement that his name was a sign of his sympathy with the Hungarians. A few trifling details, a Hungarian costume, or a few Hungarian words, would have done much to remove friction and suspicion. Men can easily be led captive by their vanity, and of that quality the Hungarians had a full share, yet the Habsburgs made no effort to flatter it, perhaps because they themselves were too conceited. Henry IV. said on one occasion that Paris was worth a mass. The love of the Hungarians would not have been bought dearly by the Habsburgs at the cost of the abandonment of a few of their prejudices, and the adoption of a conciliatory attitude. The kings frequently made it a pretext for their conduct that the Hungarian statesmen were not trustworthy. In certain case's this 


\section{DEVELOPMENT OF HUNGARIAN LIBERTY.}

may have been true, yet amid such unhappy circumstances as those of Hungary, where every step meant danger, where could the dynasty look for absolute and unselfish devotion? Was Germany or Bohemia more trustworthy during that period? The Hungarian nation had this valid excuse for its conduct, that Ferdinand could not successfully defend the country, and that after one feeble attempt to drive out the conqueror of Mohács, he left the vanquished and terrified nation to its fate.

The king should not have visited the faults of a few upon the whole nation, nor have responded to those faults with still graver ones. The Habsburgs could and should have fostered the loyalty of the nation, and their mistrust was the reason why the accusation of disloyalty became more and more justified. The disaffection displayed during the first fow years of Ferdinand's reign was the fault of the nation, but that it persisted was the fault of the dynasty in missing the favourable opportunity of attaching the nation to itself.

The Hungarian legislature did not on its part attempt to reconcile uniform military command with the independence of the country. It protested against any application of the principle of joint control. In its opinion everything that concerned Hungary or was connected with the war being waged on Hungarian territory, was an exclusively Hungarian affair. The nation's ideal was a purely Hungarian kingdom managing its own affairs in perfect independence, but the first condition of the attainment of that ideal was the ability of the nation to stand on its own feet, and this condition was absent. When the demands of a great war absorbed the strength of Hungary, and blended it with that of the king's other dominions, an independent policy became impossible. Demands which did not adapt themselves to actual circumstances remained a dead letter, and had not the slightest influence upon the development of the State. The reality was that Hungary was reduced to the level of a province, and affairs of State were settled without the nation being con- 


\section{RESISTANCE TO FOREIGN INFLUENCES.}

sulted. A foreign government had established its supremacy over the government of Hungary, and exercised control over Hungarian affairs. If the nation submitted to this, the fault lay not with the Estates, but with the king. It was the king's duty to lead the nation, because the decisive power rested with him, and his therefore was the responsibility. The Estates could not force the king in the direction of reform, but he could have realised most of their wishes. The king could only gain by placing common interests upon a proper footing, while the nation was likely to lose much.

The question was whether the fraction of a weakened nation could maintain its control over the Hungarian statesmen who were occupied with the management of those affairs in which Hungary was jointly interested with the other dominions of the Habsburgs. Would not those statesmen, dwelling in the atmosphere of the Court, become strangers to their country?

They naturally had to deal with matters which the majority of the nation could not understand, and accordingly were peculiarly open to suspicion. In the absence of a strong Constitution this community of affairs might easily lead to the yielding of the most important defences of the nation's independence into the hands of the foreign powers. Instead of an improvement of the situation there might have occurred a weakening of the nation's power of resistance. 


\section{CHAPTER XXII.}

\section{THE POWER OF RESISTANCE OF THE CONSTITUTIOA.}

The monarchial power in the age we are contemplating was in Hungary a foreign power, because the wearer of the crown did not regard himself as a Hungarian, and trusted foreigners more than Hungarians, while his nonHungarian interests and ambitions were more important in his eyes than those connected with the realm of St. Stephen.

This foreign power did not pursue a distinctly antiHungarian policy, so that the Hungarian constitution was not threatened with entire abolition, but the monarch might change his attitude at any moment, and it was doubtful what would become of the country's freedom in the event of such a change, and if the powers which had not been able to unite should clash.

Two forces had always dominated Hungarian politics. One was enthusiasm for the strength and security of the State, a sentiment which could sometimes be overshadowed, but could never be eradicated. The other was the people's intense love of liberty. The nation had always been accustomed to shape its own course, and was ever ready to take up arms in defence of its prerogatives. Before the sixteenth century the strong national sentiment and the desire for glory were powerful supports of the monarchy, but since the advent of the Habsburgs the whole situation had changed. Patriots felt a growing anxiety lest the royal power should itself endanger the country's independence. It remained for the king to show 


\section{POWER OF RESISTANCE OF CONSTITUTION.}

that he would defend the country and to disperse the nation's anxiety. He could no longer reckon upon the enthusiastic loyalty of his subjects and could only count upon a cold perception on their part of the most prudent course. Opportunism took the place of enthusiasm. It was no longer the united prompting of heart and mind which urged to loyalty, as had been the case in the time of the Arpáds, or of Louis or Matthias, for heart and mind were now in conflict with one another. The love of freedom found nourishment in considerations which had formerly checlied its exaggeration. The class privileges of the Estates of the realm came to serve an interest which they had previously endangered, that namely, of national independence. The nation began to believe that its existence could only be assured by securing the rights of the privileged classes, and it therefore set itself to defend those rights. It remained to be seen whether there was still sufficient vitality in the constitution and in the nation to oppose the king, or whether he had not undermined the strength of the constitution.

As we have seen the Diet had preserved its most valuable rights, the voting of troops and money. The king could not arail himself of the nation's strength without the consent of the Diet. Unfortunately, the Habshurgs were to a great extent independent of the Hungarian taxes, and the sums they obtained from this source they spent on their Hungarian wars. The taxes were really more needed by the nation than by the king. If the taxes were refused, the nation suffered. The king could obtain men and money from other sources, and the nation asked him to use them for the benefit of Hungary. Herein lay a great danger to the country's independence, for what would be the fate of Hungary if its defence were entrusted entirely th foreign forces? Legally the Estates could determine the extent of the sacrifices which the nation was to make, but the actual situation prevented them from exercising that right. What was legal was practically impossible. The principal means of the peaceful defence 


\section{DEVELOPMENT OF IIUNGARIAN LIBERTY.}

of their rights was in the hands of the people, but the people were too feeble to use effectirely this weapon. The I iet had lost that influence upon the executive which it had possessed under the Jagellos. Bureaucracy had begun its work. It had led to the creation of officials who were trained to obey, and who expected everything in life from their office. But bureaucracy only spread among the higher official circles. It never gained a hold over the provineial government, as it did in France. And even in the centre it only extended to certain bodies. The highest althority, the Hungarian Council, was one with the nation, and it was composed of the leading nembers of the Estates. The bureaucratic bodies, moreover, had less influence than the authorities which they displaced, because of their recent formation. They lacked the authority which only ancient traditions can give. The wearer of the sacred crown, whose predecessors had been in close touch with the nation, and whose prestige had lent authority to their representatives, was far from the country. The machinery whose mainspring was in a foreign country commenced to slacken. If the Habsburgs had realised how important Hungary was to their future career, they would have spent more time in the country. They desired to increase their power, but omitted to take the step that would have led them to their goal. The king's influence over the executive was greater than it had ever been before, but the influence of the executive over the country was less.

The power of the executive government was lessened by decentralisation. The establishment of the Turkish power in the centre of Hungary, from whence it could threaten every part of the royal territory, had hastened the process of decentralisation, which since the death of Matthias had been rapid. Many of the counties held united meetings, and gradually an instrument of autonomy was developed, which stood between the Diet and the inhabitants of the counties. The importance of these meetings increased. They decided upon general arma- 
ment, and imposed war taxes, although this function had been made the monopoly of the Diet by a law passed in the time of the Jagellos. The meetings were usually convened by the Palatine, the County Lieutenant, or the district captains, but on occasions of urgent necessity the representatives of a threatened district assembled without being officially summoned, merely at the call of some nobleman.

The king saw that these uncontrollable assemblies might become dangerous, and frequently expressed his displeasure with them. In 1597 he even prohibited them, but necessity proved stronger than the king. A government which is unable to defend the country cannot prevent the various districts from taking measures for their own protection.

Even the kings were glad of the money and men that the counties offered them, and overlooked the unlawfulness of the source from which the supplies came.

The nobles of the various districts of the country became accustomed to new centres, and to an authority independent of the central government. The organisations which had been formed for the purpose of fighting the Turks were likely to become the organs of a war for freedom. The different districts lived an independent political life, and they gradually prepared the way for an attack upon the royal power.

The autonomy of the separate counties also increased. It was in 1548 that the law was passed which made the post of deputy county lieutenant subject to election. The sphere of activity of this official had been considerably enlarged. In former times he had been a mere tool in the hands of the county lieutenant to whom he owed his appointment. Since 1542 the law had assigned to him many important duties and privileges. The county lieutenant frequently exercised authority over several counties, or held other offices, or was away at the wars, or in charge of some frontier fortress, and could not devote so much time and energy to a single comnty as the deputy 


\section{DEVELOPMENT OF HUNGARIAN LIBERTY.}

lieutenant, who always resided there, could give. 15:36 the county had gained the right to control the lieutenant. In the exent of complaint by the county, the king was obligred to dismiss the lieutenant, the only county official whom he had appointed, and to appoint in his place someone acceptable to the inhabitants. The county officials maintained peace and order; they punished murderers, and all other kinds of law-brealers, re-occupied stolen territury, and prosecuted the turbulent and predatory soldiery.

Even the important functions of recruiting soldiers and collecting taxes were dischareed by the county itself. The central executive had no scope for its activity in the counties, while these gained an important influence in the centre. IVe have already seen that even before the time of the lIabsburgs practical considerations had made it clesirable that representatives should be sent to the Diet instead of the whole nobility appearing there. The aentry tried without avail to oppose the new methods, but after the battle of Mohács all attempts to revive the old system ceased. The gentry, who had formerly received a general summons to attend the Parliament, now elected representatives at the county meetings. The general situation explains this reform. The nobles could not leave their homes in great numbers because they feared an attack by the Turks. Travelling was dangerous and costly, while life in the centre was expensive. Money was scarce, and what could be got was needed for the soldiers, or for repairing the fortresses.

The adoption of the electoral srstem furthered decentralisation. Those who formerly had taken a part personally in the work of legislation now sought to secure more influence upon the legislature than the mere right of voting at an election. They gave directions to their representative. They not only chose the individual who was to wield their rights, but determined the policy he was to pursue. The county organisations sought to make their united influence felt from a distance. Had the direc- 


\section{POIVER OF RESISTANCE OF CONSTITUTION.}

tions given to the representatives been obligatory, so that a vote contrary to them would have been invalid, the influence of the counties would have been supreme, but things never went quite so far. The instructions given carried no compulsion, though they exercised a certain pressure. Only in very important cases, and after thorough study of the changing political situation would a representative venture to ignore the will of the county to which he was attached, not merely by the tie of his temporary mission, but by all his interests and associations. The Diet remained the centre of the community, but it came under the moral influence of the county organisations. The directions received by the representatives did not prevent the transaction of business, but they increased the Diet's power of resistance to the exaggerated demands of the king. The members frequently declared that they could not discuss the proposals of the Government because the instructions they had received said nothing on the matters in question, or sometimes they said that they were not in a position to assent to the king's proposition as if they did so they would come into collision with their electors. Those who hold the power in their hands are no friends to this system of giving directions. Gabriel Bethlen, Prince of Transylvania, requested the counties not to give such instructions to their representatives. As he aspired to the throne he was afraid he would find it more difficult to influence the counties than the representatives.

The organisation of the Diet was such as to render it more difficult to influence than it had formerly been. The mixed crowds, with many uneducated persons among them, which had constituted the national assembly under the Jagellos, were susceptible to the commonest canvassers' tricks, and could be easily led, but now the Assembly was smaller in number and consisted of richer and better educated men, specially selected for their task. Also, while in former times the Diet was easily accessible to the ruling powers if they desired to influence it, now the Gov- 


\section{DEVELOPMENT OF HUNGARIAN LIBERTY.}

ernment had either to free the representatives from the control of the counties or else had to influence the counties themselves, which possessed a strong political organisation, were frequently situated far from the centre, and in which the government had hardly any representatives. The constitutional development of the sixteenth century may be summed up in a few words. The central government and the nation became more independent of each other. The influence of the Diet upon the crow'n and the "entral administration grew less and less, and vice versâ. This state of things did not promise a brilliant career for the nation. Great achievements can only be looked for when all the factors of a State act harmoniously. On the other hand, it was this very looseness in the relations between king and people which alone enabled the weakened nation to preserve its independence under a monarch who relied upon his foreign resources. It was only the exaggerated decentralisation which made it possible for the Hungarians to defy even their own government. Internal unity of the State would have given the crown absolute power.

As it was the monarch could not compel obedience. He might go his own way, but he could not kill the soul of the people. In this connection it was of the utmost importance that practically the whole nation was armed. Whereas in other countries peaceful occupations claimed the majority of the inhabitants, and the work of defence was entrusted to a class of professional soldiers, in Hungary military service was universal. Besides the duty imposed upon the aristocracy of personal service in the wars, they had also to equip and maintain a certain number of soldiers in accordance with the extent of their possessions, and this burden rested upon them even when the country was at peace. All classes of the community were accustomed to warfare. The camp was their real home, and they could defend the constitution with the skill they had acquired on the frontier. Resistance to the king was made easier by the division of the army according to 


\section{POWER OF RESISTANCE OF CONSTITUTION.}

counties. The county troops served under the county banner and were led by a captain appointed by the county. While in former times the bulk of the army had consisted of the banderia of the great dignitaries standing near the throne, now, when there was no Palatine, when the Vajda of Transylvania had become an independent ruler and the district of the former Banus of Temes, a Turkish province, and when most of the ecclesiastics had lost all their property, the county troups filled the vacant places, and from being a reserve force became the fighting line. The banderia of the less powerful nobles had also become fewer.

It is true that wery noble had the right to make a separate banderium of his soldiers, but few exercised the right. Even those who could have collected sufficient soldiers from their various estates rarely did so, because they preferred the men to remain as a garrison in their fortresses. In 1.595 it was forbidden by law to collect soldiers from different counties into one banderium, and consequently the county troops, instead of forming private banderia, became the nucleus of the national army, and the independence of the counties created independence in the army.

The scattered nature of the fighting had a similar consequence. The whole country was eager for an attack upon the Turks (1604). This favoured the concentration of all the armed forces in the country in one line of battle, and a united adrance against the enemy at a time when most of the Turkish forces were far away from Hungary. But the men and the money necessary to make this forward movement effective were rarely obtainable, so that the country had to be satisfied with acting on the defensive, and the defence could only be carried on by the several districts. The Turks occupied the area between the Danube and the Tisza, and from there they could threaten every point on the Hungarian frontier, so the Hungarian troops had to be dispersed over the long line of fortresses. It was not one great army that defended the 


\section{DEVELOPMENT OF HUNGARIAN LIBERTY.}

country, but several small armies. The political consequence of this localisation of the defence was the increasing independence of the national army. Troops voted by the Diet were generally placed under Hungarian officers, and only came indirectly into communication with the foreign commanders. When the whole of an army is together in one camp the military chiefs can make their authority felt more easily, and had this been the case the foreign leaders would have had more influence. As it was, most of the Hungarian soldiers were accustomed to obeying Hungarian officers, and in this circumstance lay one strong defence of the nation against the encroachments of the king. But neither was the king defenceless. His position in the provinces was better in military matters than it was from a political point of riew. He always took care to have non-Hungarian forces in the country, even in opposition to the law. His foreign soldiers were under foreign leaders, and the Hungarian soldiers, who were paid out of the king's personal income, were also mostly led by foreigners, and all these, together with the foreign commanders, placed over the national army in contravention of the law, could be used against the nation. The conflict between king and people might easily have become a conflict between the different sections of the army.

The great need of the nation was a strong standing army, for only by such a force, well paid and well disciplined, could the Turks have been conquered. One of the reasons which prevented its formation was the mutual distrust of king and people. In 1595 the Estates proposed that a standing army should be created, but the king would not assent to the proposition. His Viennese Council feared lest such an organisation might be turned against the king. In 1604 it was the king who, acting on the advice of Thurzó and Pethe, tried to persuade the Estates to establish a standing army, but then the Diet was afraid either of the expense or of the preponderance which the army might give to the royal power. Neither 


\section{POWER OF RESISTANCE OF CONSTITUTION.}

party was sure which would become master of the proposed army, and this doubt stopped all action in the matter. The plan would certainly have involved great expense. To maintain a permanent army perpetual taxes would have been necessary, and an army maintained by taxes which the Diet could not refuse to grant, and led by foreign commanders, would have meant the end of the nation's freedom. The power of resistance of a community depends largely upon the degree of its internal harmony. As we have seen, Hungary's pre-eminence among the countries of Europe was due to the perfect unity of its nobility. Even to-day this is a source of its power. It was to this circumstance that the community owed its constitution, and at the commencement of the seventeenth century this unity enabled the Hungarians to equip considerable forces for the defence of that constitution.

Just before the battle of Mohács the nobility appeared to be threatened with disintegration, the magnates and the gentry drifting apart, but the events which followed that catastrophe put an end to, the process. Many great noble families became extinct and families belonging to the gentry were elevated to their place, and these could not forget their origin.

The course of development of the sixteenth century was determined by the Turkish danger and the work of defence which that danger entailed. The necessity for united action could not fail to foster the esprit de corps of the aristocracy. The magnates and the gentry had to defend their fatherland together or die together. The owner of a fortress became again the natural defender of a district and the leader of its forces. The Diet was no longer a battleground for the various sections of the nobility. Sometimes, indeed, there occurred vehement scenes between the bulk of the gentry and certain of the great nobles, but these were not due to class differences; often they were attacks upon some local despot.

The difference between the magnates and the gentry was that the former were more apt to make concessions 
to the king than the latter, but even this did not spring from class selfislaness. It was the magnates who suffered most from the increase of foreign influence. The dominions and military dignities granted to foreigners and the small importance of the Hlungarians hurt the feelings of the prond magnates. It was in the service of the state that they had grown great. If foreigners supplanted them their future advancement was made impossible. If the magnates were more conciliatory to the king than the rest of the nation it was because of aheir opportunism, a quality usually more in widence among those who have much to kese than in the masses of the people, who are generally intransigent. This was so in Jungary, and if we remember that the court took much more pains to win the great nobles than to conciliate the others, we can easily understand why their upposition to the king was less pronounced.

The value of the unity between the different strata of the nubility was enhanced by the circumstance that the Habshurgs then commenced to distribute titles. IV ithin the Hungarian nobility there began to be established such stadations of rank as existed in the other European countries. The magnates, who were in frequent communication with the nobles of the western states, became accustomed to use their titles. In former times only a few of the noble families had titles, and those who had, rarely used them. Now great changes were to be observed in both these respects, and in the new graduated nobility the title belonged not only to the head of the family, as in England, but to all its members, in the continental fashion.

These outward signs corresponded to inner changes. It was at this period that the sentry ceased to play a direct personal part in the work of legislation. This derelopment did not affect the rights of the magnates, who were indiridually inrited to the national assembly. They had the means to attend the meetings of Parliament, and their word was so weighty that their presence was desirable. 


\section{POWER OF RESISTANCE OF CONSTITUTION.}

They alone remained in possession of their ancient rights because only they could bear the burden of them. It was fortunate for the nation that the harmony between the various classes of the nobility still remained undisturbed and that to political and religious disintegration there was not added class discord.

Intermarriage, too, was frequent between the magnates and the gentry. The leading factors of the nation came into no collision, and they did not seek the support of the crown against one another; they were still capable of common action for a common aim, the country's freedom.

Unfortunately, the wealinesses of the old Hungarian community also remained. The bourgeoisie did not live in harmony with the nobility. The county and the town were drawing closer togrether in legal respects but not in sentiment. Unlike the magnates, both county and town elected parliamentary representatives, and they frequently took counsel together. They became accustomed to working side by side. The link which became noticeable in England after the thirteenth century, and which played an important part there in creating the united middle casses, was forged in Hungary also. But the bourgeoisie was of foreign origin and it had maintained its foreign character. The towns excluded the Hungarian and titled elements from their ranks, and left them no share in the administration. In most towns they were not even allowed to buy houses. In official life the German language was used, and the bourgeoisie being foreign was attached to the foreign ling. The monarchs therefore desired to increase the number of those "free royal towns" which sent representatives to the Diet, but their efforts met with great opposition on the part of the nobility.

If the nobility were opposed to the king, the towns were driven by their interests into the royal camp, and a clever king could have turned this situation to very great account.

The other weak point of mediaeval Hungary was the discontent of the peasants. These were not attached by 
any ties to the free men of the country. The system under which they lived demanded great sacrifies on their part. They had to serve as soldiers and to work at the building of fortresses; it was their forced labour and their taxes which supported the state, the landowner and the church. Their rights, however, had been reduced to a minimum. They were bound to the district where they were born. They could not leave their master however tyrannical he might be, and the constant wars threatened their little property and even their life. It was their class that paid the greatest tribute in blood and money to the war, and yet had the least profit from rictory. They could not fight with enthusiasm for such a system. Sometimes embittered feeling carried them so far that they were ready to help the Turks against the community that sucked their blood, but as a rule they were still more afraid of the pagans than of their Christian masters and therefore they clid not hamper the work of defence. Yet it was easy to guess that the serf class would look with perfect indifference upon the struggle for privileges between the Hungarian nobility and the king. He who enjoys no rights whatever cannot be enthusiastic about the rights of some other class.

In the eyes of the serf the landowner represented the state. It was to him that they paid their taxes. He administered punishment and enforced the "blood tax." His selfishness had deprived their class of its rights. On the other hand, what protection they did enjoy came from the landowners. If there was anyone desirous of maintaining the working strength of the peasants it was their master, because of his own interests. In case of need it was the landowner who fed them, and although there were some who treated their serfs cruelly, many were humane towards them and took good care of them.

The king was more remote from the peasant class. No direct responsibility for their fate lay with him, and consequently he rarely came into collision with them. He tried to ease their lot. As far as he could he pro- 


\section{POWER OF RESISTANCE OF CONSTITUTION.}

tected the weak and at the same time served his own interests by winning over the people, who strengthened his arm against the nobility. But no great results came of his efforts in this direction, for he could not overcome the resistance of the Estates. The right of free migration of the serfs, in particular, was not to be carried through, principally because of the gentry, who, as they provided the least defence to the peasants, were most afraid that their worliers would leave them and would move to the neighbourhood of the strong fortresses, commanded by the powerful nobles or by the king.

The execution of the law was entrusted to the gentry, that is, to the very masters of the serfs, so the peasants received little benefit from the king's activity. And even though the king tried to increase the rights of the peasants yet it was he who dealt their class the heaviest blows. His soldiers were the cause of their most serious grievances, and it was the king who tried to increase their taxes in spite of the Estates, and who exacted their forced labour, and further, it was the king in whom the peasants saw the cause of the constant wars.

For the peasants, therefore, there was little to choose between king and nobles and neither party could reckon upon their devotion. Although some landowners had gained the affection and loyalty of their peasants, while some were hated by them, the large majority of the serfs looked with perfect indifference on the struggle. The fate of the state and the constitution did not interest them, but, naturally yielding to the strong, they did not refuse their support to either of the contending parties. They joined neither party willingly yet with compulsion either could dispose of them.

It was specially dangerous to the Hungarians that one large class of the nation should remain entirely indifferent, hecause the king could always count upon support from abroad.

At the time of Bocskay's insurrection (1604) King Rudolf was adrised to free the peasants and lead them 
to war against the nobility, and although the ling did not dare to adopt this course, yet the possibility of such advice showed lhat the condition of the peasants constituted a grave danger to the national cause.

The fault of the situation lay with the nobles and they had to bear the evil consequences. It was no fault of the king that he could not win over the peasants, upon whose lot he had hardly any influence, but it showed culpable negligence on the part of the nobility, which was in close touch with them, that it could not gain them for its cause. The fault was, of course, the prevalent fault of the times in all countries.

The strength for resistance of the Iungarian state was due even then to the unity of the whole of the nobility. The nobles had passed through a difficult period, but it had disciplined them. They discharged their manifold duties courageously and one might say that they were the state. Their love for freedom was invincible and they themselves were energetic yet prudent; they did not seek a conflict, but neither did they aroid it. It was evident that they would not surrender their freedom, which meant their whole existence with all its interest for them, without a great struggle.

In spite of the circumstances which were so favourable to the monarch, yet in consequence of the attitude which he adopted he could only have established absolutism with foreign help. But violent methods would have been resisted not only by the Hungarians beneath the Habsburg sceptre, but also by Transylvania. It was calculated to increase the nation's strength that the eastern and larger portion of the country had an organisation independent of the Habsburgs.

It is true that constitutional freedom and respect for law were not more strongly established in Transylvania than in Hungary. Political violence, political executions and coups d' état were more frequent in Transylvania during the time of Queen Isabella and Sigismund Bathory than in western Hungary until the time of Básta. 


\section{POWER OF RESISTANCE OF CONSTITUTION.}

Yet in spite of that, the independence of Transylvania gave a powerful support to the constitution of western Hungary. All the discontented elements found shelter at the Court of the Szapolyais. The knowledge that he had a rival compelled the Habsburg king to be careful lest his subjects should go over to the enemy. And although laws and rights were not more respected in Transyluania than in the west, the position of the Hungarian element was certainly stronger. Transylvania was not a sovereign state while the kingdom of the Habsburgs was. Hungary was not subordinate to the German Empire; it was merely the person of the ruler that brought the country into connection with the hereditary provinces of the Habsburgs. Neither was it subject to the Turks, although for a long period (1547$1606)$ it paid a yearly tribute. This tribute was paid to preserve peace, but the Porte acknowledged the independence of the Habsburg kingdom. Transylvania, however, was really the Sultan's property, to which he conceded a certain measure of autonomy. He could compel Transylvania to take part in his wars. It was the Sultan who confirmed the ruler of Transylvania in his dignities and who could also deprive him of them at will. Yet Tran. sylvania possessed a freer internal government than Hun. gary, because in Hungary the king wielded his power in accordance with the advice of foreigners and the interests of his empire, while Transylvania was governed by Hungarians in their own interest. The Sultan only interfered with the internal affairs of the country in exceptional cases. If they paid him and were obedient, his contemptuous tolerance assured his subjects a large share of autonomy.

So Transylvania could easily serve as a defence against the foreign influence which endangered the independence of Hungary. The bulwark of Szapolyai's power was largely the fear of German influence in the breasts of many Hungarian patriots. It was this fear which had raised Szapolyai to the throne. In spite of the partition of the country there was much community of 


\section{DEVELOPMENT OF IIUNGARIAN LIBERTY.}

sentiment, as though there had been one soul in two bodies. The traditions of centuries counteracted the effect of partition. It is true that east and west Hungary had not yet found a way of striving in common for the achievement of great national aims. During the sixteenth century Transylvania took no part in the conflicts round the Constitution, but in the unity of feeling we see one of the conditions of common action.

And it was evident that if the prevailing discontent were to burst into flame, the political frontier between the eastern and western portions of the country would not limit the conflagration. Moreover, at the end of the sixteenth century even that frontier disappeared. Sigismund Báthory caused Transylvania to become again a part of the Habsburg realm. Transylvania shared the lot of western Hungary. Its separate organisation ceased, but a state which for seventy-five years had received the people's obedience and to which the people clung, could easily be revived.

$W^{2}$ have pointed out that the division of the country had very grave consequences, but we cannot fail to see that some beneficial results flowed from it, which grew to great importance in the seventeenth century.

The division which was a great disadvantage to the country in its dealings with the Turks, perpetuated the distrust between king and people and made the country's resistance to efforts at annexation more effective.

During the sixteenth century Hungary's freedom was threatened by many dangers, but the nation did not surrender it. Even the growth of the royal power did not destroy the resisting power of the Constitution. The country became weaker and poorer, but its people were still able to fight for its freedom. They clung tenaciously to their rights and the Constitution survived in spite of all the storms which threatened its existence. 


\section{THE REFORMATION IN HUNGARY.}

\section{CHAPTER XXIII.}

\section{CAUSES AND EFFEC'TS OF 'THE SPREAD OF THE REFORMATION IN HUNGARY.}

We have been considering the political changes which followed the battle of Mohács and we must now glance at the religious life of the times.

The Reformation spread rapidly in Hungary because the country was in such close touch with the land which had given birth to the reformed faith. The new doctrines were first carried to Hungary by the German members of the Court of Louis II., and the numerous German soldiers living in Hungary helped to spread them. The seed thus sown in people's minds were developed by the German schools of the neighbouring countries. It was especially the German bourgeoisic that welcomed eagerly the products of German thinking. But the influence of the German genius upon the Hungarians could not by itself account for the success of the new faith. The Reformation found a suitable soil in Hungary. That great intellectual revolution was brought about in Germany by forces which were also active in Hungary.

The sixteenth century was an age of great transformations. For many centuries before the Reformation the Latin and Germanic worlds had lived their own more or less isolated lives, and had formed, under the government of the Church, strongly organised systems. The very ideas prevalent in those worlds were supplied by those who also directed their every-day life. They knew no other ideas than their own and consequently were harassed by no doubts. But the time came when men grew acquainted with a whole world of new ideas, when the crusades gave 


\section{DEVELOPMENT OF HUNGARIAN LIBERTY.}

a powerful impetus to their thouglsts, and when the Christian communities came into contact with people of so different a way of thinking as the Mohammedans.

Still more important were the consequences of the widening of men's minds in two different ways. The beautiful relics of classical antiguity showed men that a world very different from their own could also be magnificent, while the discovery of America introduced a host of new ideas and of doubts respecting their former beliefs. The Church soun found that the mediaval man had undergone an entire change since knowledge had become more widely distributed. I) loring the Middle lges everything came from the Church and led back to it. Now what man learnt from Vature was different from the teachings he received from the Church. Ilis self-consciousness began to grow and the place of exagererated humility was taken by freedom of thought and the consciousness of human dignity. Naturally, the Church was bitterly opposed to the new movement which has become immortalised under the name of the Renaissance. The freed soul of humanity turned to the cult of beauty.

The prestige of the Church suffered whenever she encountered the new ideals. Bitter satirical attaclis galled her as cruelly as she had tortured humanity with her fires. Criticism was the more fatal because the Church was guilty of heinous faults. The higher ranks of the priesthood had become unbelieving in the atmosphere of the Renaissance and were the slaves of worldly pleasures, while the lower ranks were blighted by their narrow formalism and low dissolute life. The Church, which had lost all its moral influence, ret still wished to dominate, was bound to become the object of ardent hatred. The attitude of the world towards the Church can hardly ever be that of indifference. Her rocation is so high that if she answers it she must waken enthusiasm, while if she becomes unfaithful to her own ideals she is pecuopen to attack.

At the close of the Middle Ages this was the situa- 


\section{THE REFORMATION IN HUNG.ARY.}

tion of the Church. It has ever been a social necessity that the masses should have religion. Order is destroyed if the people lose their ideals. It was to the interest of all mankind that the Church should awaken to new life and give new nourishment to the minds of believers. It was this historical necessity which gave birth to the Reformation. The German mind, inclined to speculation and to thoroughness, was the first to revolt against the superstition which was at that time called Catholicism. Side by side with the Renaissance and the growth of Rationalism, religious feeling also awoke and gained ground. It revolted against the scandals of the Church and tried to find for itself new organs of expression.

The home of the Renaissance was the highly cultured country of Italy. The Reformation, on the other hand, originated in Gernany, where belief was stronger and where even the thinkers did not cast off all the old traditions. In Hungary, it was the religious movement which gained the upper hand, although later than in Germany, because the Hungarian mind, not being given to abstrac. tion, clid not adapt itself so readily to transeendental truths as the German mind.

If the brilliant era of Matthias had lasted longer it would probably have been the spirit of the Renaissance which would have becone predominant, but cruel Fate put an end to that time of progress, and later generations, which lived in misery, achersity and the frar of cleath, were more open to doctrines telling of the compensations of a future life. Missionaries proclaimed the new gospel to all peoples in their own tongues and thus found an entrance into their hearts. They impressed the Hunzarians as much by their sermons as by their books and scliools. As the Protestants were in a minority they dereloped a greater activity, and as they stood in great danger they were fervent and true.

Before the battle of Mohács, one of the great mistakes of the Church was that in conferring dignities it was largely governed by political considerations. The highest 
posts in the Church were distributed among the influential aristocratic families. Such dignities were looked upon as the preserves of the Court party. One and the same person often held several ecclesiastical appointments. He spent the incomes of them all but neglected the duties attached to them. In many cases mere children were made bishops. Perényi was hardly a youth when he became bishop, and Hippolytus of Este was actually a child when the dignity of archbishop of Esztergom was conferred upon him.

At that time bishops were obliged to take an active part in the defence of the country. It was not surprising that the nation, being in imminent danger, concerned itself more with the ability of the bishop to perform his military duties than with his ecclesiastical qualifications.

Tomori, the valiant soldier-priest, became archbishop in order to be, not a spiritual, but a military leader. The better men among the priests were occupied with military duties, while the worse lived loose immoral lives and used the disciplinary power of the Church to make money in unlawful ways. After the battle of Mohács, discipline and order were still more destroved. The priests fled, the churches were in ruins and the congregations were abandoned. The disintegration of the State helped to disintegrate the Church.

Naturally the new generation did not look to such a Church for its salvation, but turned to the Reformed Church, which pointed to the country's many misfortunes as the signs of God's wrath. The condition of the Church helped the cause of her adversaries in Hungary as in other countries.

The Reformation, howerer, was not merely a revival of the religious temper. Along with this the German spirit shook off the dominion of the Latin spirit. This explains why the Reformation triumphed more easily in Germanic countries than among the Latin nations. The new faith did not establish another centralised Church; on the con- 


\section{THE REFORMATION IN HUNGARY.}

trary, it decentralised the Church and in this way contributed to the independence of the various nations.

This circumstance made the Reformation popular in many countries besides Germany, amongst others in Hungary. One of Hungary's vital principles was that of independence. Even during the supremacy of the Catholic Church the nation guarded jealously its own Church from the despotism of Rome. It was only natural that the Hungarians should welcome a movement which promised to serve their aims.

Some time before the battle of Mohács the Popes had done more for Hungary than any king. 'They had helped the nation sometimes with advice and sometimes with money and soldiers. But of course the nation was entitled :o this help in its struggles on behalf of Christianity, in tact it had a right to expect still more effective support irom the head of Christendom. Failing this support, the nation began to feel abandoned, the more so when, after Mohács, the attitude of the Popes towards Hungary was solely dictated by cold political considerations. Ferdinand's adherents took offence at the ill-will shown towards them by the Pope, and the adherents of Szapolyai again, at the Pope's refusal to do anything on their behalf. The Pope even threatened these latter with excommunication because they had yielded to the superior power of the Turks. From a distance the Pope was ready to add to their heary burden, although he had only contributed his blessings and his prayers during a war which had cost the nation its last penny and untold lives. Hungary, the bulwark of Christianity, laid the blame at the Pope's door for her being left without any real assistance.

In spite of the growing dissatisfaction, Rome imposed taxes upon the country in the shape of sums demanded for absolutions and for Peter's pence. The grandeur of the Renaissance life at the papal court had to be paid for by the whole of Christendom, and the sums which were gained by outraging the religious feelings of the nations were often spent by the mistresses and the families of the 


\section{DEVELOPMENT OF HUNGARIAN LIBERTY.}

Popes. This situation created bad feeling everywhere but above all in Hungary, where money was lacking even for such purposes as the maintenance of the palace of Matthias. It is interesting to observe that a movement so essentially mental as the Reformation was largely helped on its way by the grasping nature of the Popes.

Another factor was the hope of sharing in the spoil of the Church. In those days of economic crisis the hope of making money became a powerful spring of action. In the spread of Protestantism selfishness played a part, as it generally does in all successful movements.

The absence of celibacy in the Reformed Church was also a powerful motive. It was a great mistake on the part of the Catholic Church that she did not at first fight for the principle of celibacy with all her might, and that when the law was put into force many priests were actually married. The wives and children naturally became adherents of the new faith.

Another great advantage to the Protestants was that they sought to emancipate the individual from the dominion of any established authority. The complex doctrinal problems, too, were all more simply explained by the new Church.

The very organisation of the Reformed Church embodied the idea of freedom. The hierarchical and centralised power of the priesthood was replaced by the autonomy of the congregations. Those who in the Catholic Church had played the part of an obedient flock, gained new power, for even their pastors were elected by them.

All these considerations were bound to endear the new faith to the Hungarians. The nation, which so dearly loved independence, welcomed the spread of autonomy in the Church, especially in the sixteenth century, when the importance of local government was increasing, since it served as a defence of the national existence.

At first Luther's doctrines became popular in Hungary, but soon the Calvinistic teaching won more adher- 


\section{THE REFORMATION IN HUNGARY.}

ents, especially among the purely Hungarian elements. The German burgesses in Hungary remained Lutheran, but the gentry, in spite of the frequent communication with the Germans, joined the adherents of Calvin and Zwingli. The faith in which the love of freedom was most pronounced, and which had rendered the greatest services to the cause of freedom, was sure to gain the most adherents. By the end of the sixteenth century the great majority of the nation had abandoned the old faith.

Let us now look at the consequences of the Reformation.

Its first effect naturally was to bring religious questions to the front. The period whose commencement had seen the laity take the intellectual leading into their own hands, and seek their ideals among the creations of the pagan world with so much fervour as to appear to lean towards paganism even in their beliefs, suddenly began to reveal the influence of religion. The Renaissance was overshadowed by the Reformation, and theology became the all-absorbing interest. How did this happen?

Protestantism by its very novelty impressed men more powerfully than Catholicism had done during the last period of its undisputed supremacy, and at the time of the Reformation the ancient creed itself was rejuvenated. Rivalry braced up the Catholic Church. IVhen she had to struggle for her existence she suddenly regained her vigour. Catholicism began to employ the same weapons that its opponent was using. It adapted itself to the requirements of the age. In religious fervour the Catholic Church overtook her rival and in organisation surpassed it. Her ability to subordinate the most contradictory elements to one common will fitted her to play a leading part in Europe. After the first defensive attitude the Catholic Church took the offensive. That great power stepped forth in full armour to the battle, using intellectual and material, political and economic weapons, persuasion and compulsion, verbal and written controversy. This 


\section{DEVELOPMENT OF HUNGARIAN LIBERTY.}

titanic struggle overshadowed all other interests, while involving them all.

State life and religions life had bern carried on ride. by side for centuries. In the Middle Ages the State was an organisation of people of one religion with certain secular aims. The State had been organised under the influence of the Church. Even the dignities of the Church were State dignities. The priesthood was an order of the State invested with special rights. The State, along with its own aims, served atso those of the Church. One of its chief duties was to maintain the supremacy of Catholicism, and to punish heretics. Even those monarchs who fur political reasons were at war with the lope himself, did not rofuse their support to the Catholic faith. They defied the temporal power of the Church, but they maintained the authority of her dogmas. Within the limits of the State there was only room for the one religion: as soon as any other made its appearance the State persecuted it hecause Catholicism was one of the foundations on which the State rested. The peaceful co-operation of several denominations was an unheard-of notion, and it would have been contrary to the mediaval conception of the functions of a State.

The Reformation was hound, therefore, to cause a tremendous revolution even in State life. Some States faroured the revolution proceeding within the Church. They tried to solve anew the problems of ecclesiastical power and wealth. But their ideas as to the relation between State and Church remained unaltered: they merely substituted a new faith for the old one, and still aimed at assuring the supremacy of one faith.

Other States again sided with the old religinn. Any attack upon this was resarded by them as disloyalty to themselves, which they could not tolerate even for political reasons.

So throughout the whole of Europe religious persecution was carried on even by the most enlightened rulers, because they were afraid that if any other faith than 


\section{THE REFORMATION IN HUNGARY.}

the one established in their dominions were to flourish, it might menace the monarch's authority. Religious uniformity was really a political interest.

This struggle between the rival creeds was made passionate by the intolerant spirit everywhere prevalent. "The Catholic Church had long regarded heresy" as the worst of sins. Spiritual perfection included implacable hatred of heretics. And although among the Protestant dogmas there was none concerning their own infallibility, yet it was one of the convictions of Protestants that the adherents of the wrong faith were doomed to eternal punishment.

The harshness of the opposing Churches was augmented by selfishness. Each hoped to increase its power by the employment of violence.

Faith is a condition of the soul, independent of the will. Fear and self-regarding wishes can only move the will. External means can neither create nor eradicate any real conviction. Still, brute strength, if it is ready to kill and does not slacken in its ruthless work, if it is not afraid to destroy the soul as well as the body by $\mathrm{com}$ pelling it to lie and play the hypocrite, can extinguish whole communions.

We often hear it said that the martyrdom of those who die for their religion, wins new converts to the persecuted faitli. This is only true, however, when the persecuting power does but half of its work, and the blind hatred and fanaticism which prevailed in medieval society enabled the persecutors to do their cruel work completely.

To-day the whole situation is, of course, different. The very effort to extinguish any denomination or nationality would now be a great political blunder, because being opposed to the spirit of the age it would inevitably fail, and would cause a reaction, even if the persecution were to be incomparably milder than it was during the Middle Ages.

Violence is most terrible when even good men share 


\section{DEVELOPMENT OF HUNGARIAN LIBERTY.}

in its deeds. While only contemptible motives prompt to the work of destruction, reaction must come sooner or later, because there has hardly ever been a time when the good entirely lost their power. In the Middle Ages religious persecution was so deadly because it was a sense of duty and a certain idealism which kept it alive. This explains its success, and also why it comld becone the source of as) mush injustice and calamity.

IVhen religious uniformity was dentroyed a struggle inevitably ansurd which afferted the whole traditional organisation of Christendom as well as the internal order of all the various States. Sll the links which for centuries had mantained the unity of Europe became loose, and new ties of intrest and forling were created.

The international relations of liurope and the inner life of the states were determined by religious considerations. During the sixteenth extury, in most of the States, such a degree of persecution was reached as amounted to nothing less than religious warfare. In Spain and in ltaly the new roligion was entirely extirpated by the old, which in those countries was supported by powerful political interests. In England, after several crises which breught many to the scaffold and the stake, the Reformation prosed victorious. It triumphed in Sweden also after less violent conflicts than in England. The Vetherlands were torn into two parts in consequence of the impossibility of reconciling the new faith with the old, and with the Spanish government. The eastern portion, after superhuman exertions, formed an independent State, and assured the supremacy of the new faith.

The religious struggle acquired an international character. The Spanish Habsburgs, counting on the support of the Latin world, and encouraged by the Popes, made an effort to reconquer the whole of Christendom for Catholicism. They spent enormous sums of moner, and poured out the blood of their subjects in the interests of Rome. Spain was exhausted by internal violence and the strain of her colossal efforts, and lay 


\section{THE REFORMATION IN HUNGARY.}

ruined by the fanaticism of her rulers and people.

In the international conflict the northern German powers became the antagonists of the southern Latin world, and the champions of the new faith. France and Germany were the battle ground for the strife. In the sixteenth century the unity of France was almost destroyed by the violent conflicts between the Huguenots and the Catholics. In Germany, the religious question did not bring on a crisis until later. State life in Germany was so loosely organised that the greatest contrasts could exist side by side within the limits of the Empire. The attitude of the German Habsburgs, also, was such as to render it unlikely that a religious war should break out. They tried hard to find a compromise between the two conflicting views.

It was the great political ambition of Charles $V$. and the comparative weakness of his successors, which led the emperors to aroid the spreading of a catholic reaction in the German Empire. It is true that towards the end of the reign of Charles V., there were two wars. caused by the steps which that monarch had taken in the interest of religious uniformity, but a final reckoning could still be postponed. It becanle the right of the various provinces of the Empire to regulate their own religious affairs, and the Empire split into sections hostile to one another. Each of them had long had political and dynastical interests opposed to those of all the rest, and to these was now added religious animosity.

The Empire was threatened by very grave dangers. The imperial government, which was unable to settle the most vital questions, lost its authority. Alliances were formed on a religious basis, and foreign support was sought by the provinces against one another. Only a spark was needed to set the whole of Germany in a blaze.

The serenteenth century provided that spark, and Germany became devastated by religious strife.

What effect had this crisis, the gravest which had occurred since the migration of peoples, upon Hungary? 


\section{DEVELOPMENT OF HUNGARIAN LIBERTY.}

Hungary could not remain unaffected by the prevailing religious animosity, but it is pleasing to remember that religious hatred nerer became so virulent there as it was in other countries. Religious prosecution was comparatively mild and never developed into a religious war, and the Hungarians shed less blood than other nations in attaining a state of religious toleration. Although previously to the battle of Wohács the old Church had tried to turn all its forces acainst the heretics, the severe law, which was entirely in keping with the spirit of the times, was never enforced. l'erhaps there were a few executions, but far fewer than in any other country. After Moháes, no attempt eren was made to renew the law. In 1.548 the country's legislators stond up for the old Church, but they employed milder methods than were usual, and it was above all the reform of the priesthood itself that was urged by them; in this they saw the right way of putting an end to heresy. They pursued the policy of Charles $Y$. and asked for a gineral synod in order that the differences of opinion might be discussed there. They did not refuier the I,utherans to be punished, except their preachers, who met with some severity of treatment. The law was sterner towards the weaker serts of the Calvinists and Anabaptists, and ordered the confiscation of the estates of all members of these denominations. Later on (1.50, '53, '54, '56, 57,59 and '6i3), even this harshness was moderated. The Calvinists were no longer included among those who were to be banished, and the more severe laws were only renewed against the Anabaptists, who fell into exaggerations dangerous to the common peace and security.

In 15.59, however, even the Anabaptists were only punished by the imposition of a special tax. The actual situation was even more favourable than that indicated by the law, because the law was not enforced. I utherans and Calvinists all enjoved tolerant treatment. They had their churches, in which they were allowed to hold their services. There were no martyrs among them. 


\section{THE REFORMATION IN HUNGARY.}

By the end of the sixteenth century the great majority of the nation professed the reformed faith. It is a noteworthy fact that neither party tried to force a settlement of the religious question. The Catholics, when they were the stronger, did not insist upon the execution of the law, as happened in other countries, and the Protesttants, when they were the more powerful, did not demand anti-Catholic legislation, or claim any exclusive rights. They were satisfied with the tolerance which they had gained.

Neither did public life show the effects of any very powerful religious animosity. The mind of the nation was governed by political considerations. The division of the country did not take place along denominational lines, but along political lines. The western and the eastern portions were both mixed as regards the religion of their inhabitants. The parties were always political, and not religious. In 15.54 the Diet, the majority of whose members must have been Catholics, elected the Protestant Nádasdy as Palatine. In the royal council there sat several Protestant nobles who had a voice even in the election of the Catholic bishops. It was a Protestant nobleman, Illésházy, who recommended the fervently Catholic priest Szuhay as bishop. Those counties in which the inhabitants were all Protestants paid tithe to the Catholic Church without demur.

It is difficult to pursue a tolerant policy in an intolerant country. In such a country the government which hesitates to join either one or the other of the two bostile camps must fail. Political systems which stand far above the ideas of their time can rarely be lasting. Statesmen who are in advance of their age can only render good service to their country if they are content to moderate the faults in which the community is apt to see a merit. The forcing of prinriples upon a society which is not yet ready for them, senerally leads to reaction and defeat.

The tolerant system of King Maximilian became the test of the liberality of Hungary, and of the neighbour- 


\section{DEVELOPMENT OF HUNGARIAN LIBERTY.}

ing countries. In Austria and in Bohemia it did not prove good or useful. Neither of the rival communions was satisfied with the ruler. The Protestants expected one who had shown them sympathy to establish their supremacy. In one instance they went so far as to ask the king that the Catholies might be forbidden to hold their services. The Catholics, on the other hand, were not inclined to agree to so much tolerance on the part of the monarch as he had shown to the Protestants. His moderation made Maximilian unpopular, and as he made Protestantism stronger without annihilating Catholicism, but only embittering its adherents, he only made the ineritable struggle more fierce when it did come.

In Hungary the situation was different. It was a sign of the nation's good sense that in Hungary Maximilian could be tolerant without creating resentment. The nation did not urge him to decide the denominational question, for it regarded political and military questions as more important.

In Transylrania the triumph of the national idea over the denominational one was still more pronounced. There the instinct of the nation was not disturbed by the international political situation, and so the people passed a law of toleration.

The Habsburgs, although they did not blindly serve the interests of the Catholic reaction, yet identified themselves to such an extent with the Catholics that they could not openly proclaim religious liberty. Maximilian did not dare to assume this attitude, although he was inclined to do so, for he was afraid of offending the Spaniards and the Pope, as well as the Catholic electors of the Empire.

The government of Transrlyania was free from such considerations, and could give free play to the national instincts. Martinuzzi himself, although a Catholic priest and a fervent defender of his Church, never went so far as to persecute any other communion. After his death a still more liberal attitude was adopted; the new deno- 


\section{THE REFORMATION IN HUNGARY.}

minations were all legally acknowledged, and no efforts were made to assure the supremacy of one faith over another. The Protestant legislators, although forming a majority, roted for Stephen Báthory, a Catholic, as their ruler.

In most other countries tolerance was at length practised, because of the dreadful results of intolerance, while Hungary had to pay comparatively little for the lesson she learnt as to the better course.

True tolerance is seldom found even to-day in ardent souls. Tolerance in matters to which men are indifferent, or where they see no great contrasts to their nwn ideas, is frequent enough, but where conviction is strong and great contrasts involved, the virtue is very rare. It can only be cultivated by those who can see in the convictions of others the natural outcome of a whole mental history, a result for which nobody can be held responsible, and who would regard it as a crime to exercise force or compulsion upon anyone's conscience, and are lenient even in the case of errors, because they do not consider themselves infallible.

Tolerance can have a firm and broad hasis only where men feel that to punish erring thought means to block the path to truth, since truth can only be approached by means of free thinking, which can never be secure from the possibility of error. But this idea could only gradually banish the belief current in the Middle Ages that it was pleasing to God to persecute those professing a different creed.

Tolerance is often due to mere concessions to the requirements of practical life, and to a compromise hetween conscience and the spirit of opportunism. In the sixteenth century tolerance was due only to such a compromise. Only a few exceptional men grasped the principle itself. No whole nation anywhere had become truly tolerant. Hungary was not so enlightened as many other nations which pursued, nevertheless, a much more intolerant policy. Rationalism was more advanced 


\section{DEVELOPMINT OF HUNGARIAN LIBERTY.}

in some nations which in respect of Liberalism were behind Hungary. While in Italy, France, and Germany religrious wars were being waged, and the adherents of the different faitls could not live side by side in peace, in Hungary the various denominations found a "modus vivendi.' The strength of the national sentiment and the consciousness of the nation's danger, tempered religious intolerance.

The nation's political instinct achieved more than culture did in other countries, because more of the leading men were guided in Hungary by that instinct than in other countries were influenced by enlightenment.

That powerful political instinct which tempered the people's intolerance was the same that had giren strength to the monarch at times when the monarchy in other lands was helpless before the nobles, and that assured the unity of the government when in many countries it was broken to pieces.

The tolerant spirit displayed by the Hungarians was of the utmost value, for it was able to save the nation from extinction, though, naturally, religious animosity was not entirely banished.

The stronger sects, which could endanger the peace of the country, met with very fair treatment, but the weaker ones did not. Toleration was accorded to the various communions gradually, as they became stronger, first to the Iutherans and then to the Calvinists; but the Jews, the Greek-orthodox Church, the Unitarians, and the Anabaptists, were exposed to strong attacks. Multitudes of the peasants were debarred from the free exercise of their religion, as they were at the mercy of the squires. The existence of the smaller denominations was very precarious. Although no religious war broke out, yet frequently in private and social life religious interests clashed. Sometimes there were scenes of riolence, natural enough during a time of anarchy. The powerful landowner propagated his faith with the aid of armed force. Churches were frequently taken by the represen- 


\section{THE REFORMATION IN HUNGARY.}

tatives of one creed from those of another. It was not intolerance which in that age wore a mask, as is the case to-day, but tolerance. The priests inculcated hatred of their opponents, and a protestant student openly declared that the people should be led, not against the Turks, but against the Catholics, for they were the more dangerous foe.

Naturally, Hungary could not escape the religious strife which occupied the whole of Europe. Both halves of the country were troubled by the religious problem. The government of the western half was in the hands of a Catholic dynasty. Legally, Catholicism was supreme there, but actually the Protestants were the stronger party. This state of affairs was calculated to rouse the Catholics to vigorous action. The Habsburgs were urged on every side to attack the Protestants. The tolerance which was possible in Hungary was impracticable in their other dominions. The Catholic reaction began to drive back Protestantism everywhere. The question was how long the political sagacity of the HIngarian nation would resist this powerful counter movement which had the king's sympatly. Among the Hungarian priests a decidedly uncompromising spirit manifested itself. Some fanatics began to speak of compulsory Catholicism. Under these circumstances it seemed as if the Protestants might have to demand some modification of the laws in order to protect themselves from the growing danger.

At the commencement of the seventeenth century, when in the whole country there were only three hundred Catholic priests, and the great majority of the population was protestant, the greater part of the royal council was composed of Catholic bishops. Such a situation could not last.

The dynasty and the nation were under the sway of two directly opposite ideas. Religious differences, which at that epoch could divide whole nations into hostile camps, and armed men against their own kindred, still 


\section{DEVELOPMENT OF HUXGARIAN LIBERTY.}

further estranged king and nation, already embittered against each other.

At the end of the sixteenth century Transylvania had again a Catholic ruler, but most members of the leading classes were Protestants, so that a violent outbreak seemed probable. Ind as the legal organisation of one half of the country was based upon Catholicism, while the other half showed Protestant tendencies, differences of creed were likely to make the two sister States real enemies. The fuel for an impending conflagration had already been stored up, and now religious antagonism added to the heap. Internal peace was only ensured by the weakness and the dangerous situation of the king and nation. State life, both in religious and in political respects, meant only a compromise of opposing forces, and not their harmonious co-operation.

What effect had the religious situation upon the balance of power? IVas it likely to strengthen the king or the people?

The Catholics were in the minority, but the Protestants were not united. If the Catholic reaction had forced the conflict to a life and death struggle in which all the Protestants would hare been obliged to unite, the bulk of the Hungarians would have been on the side of the Reformed Churches, but the strength of the Protestants was greatly diminished by the circumstance that the burgesses of German origin were Lutherans, while the gentry were Calrinistic, a situation of which a skilful policy could easily have made use.

Protestantism was strengthening the spirit of liberty. It was especially the Calvinistic Church which waged war against the authorities whose supremacy conflicted with the rights and liberties of the individual. As the legal authorities persecuted the Calvinists, naturally the idea that tyranny might be resisted even forcibly spread more and more in the Calvinist ranks. The spirit which had inspired the Golden Bull gained new strength. 


\section{THE REFORAITTION IN HUNGARY.}

If the ruling power identified itself with the Catholic reaction, and if the strengthening of the royal authority endangered even a man's conscience, the resistance to the king would have a new motive, as one more great interest required defence. The nation's existence, the people's freedom, and the religious life of the majority, were equally threatened. When the Catholic and absolutist movement unfurled its banners, at once all classes of the nation sprang to arms and assembled in one common camp.

One other foundation of the nation's existence and independence was strengthened by the Reformation, namely, the national language. It was througl the religious controversies and sermons that Hungarian became a literary tongue.

A language is the outcome of a nation's individuality, and of its peculiar qualities. İ one nation speaks differently from another it is because its whole history, its soul and body, have been different. On the other hand, this very difference between the nations is increased by the linguistic difference which springs from it. The more exclusively a language prevails within a community, the more isolated that community will be from others, and the less will be the effect upon its thoughts and feelings of the surrounding countries. It will become national in its whole being.

In the Middle Ages culture was essentially Latin. National languages were driven into the background by that one international tongue. The Reformation was in one aspect a revolt against this. It was in harmony with the logic of facts that the movement which tended to free the nations from the influence of Rome should set the national languages above the Latin tongue. The fervent apostles of the new faith cultivated the national languages because by their means they could get nearer to the hearts of the people. The Catholic Church could not neglect this movement, for she could only keep pace with her 


\section{DEVELOPMENT OF HLNGARIAN LIBERTY'.}

rival if she also could speat to the masses in their own tongue.

Thus all over Europe a great revival of the national idioms was to be observed. With the development of the Hungarian language the conviction grew strong in the nation that it was an isolated race, which must be independent if it desired to thrive.

The Reformation then affected the fate of the Hungarian State in two different ways. It disturbed its inurnal harmony, and increased the number of causes of collision between king and people, but, on the other hand it angmented the powers which were on the side of the nation in the conflict. The Reformation helped to bring matters to a crisis, it estranged king and nation, and stimulated absolutism to an attack, but at the same time it gave means to the nation for an energetic defence asainst that danger. Ihsolutism would have been more harmful, and therefore more hateful at that time than at any other. 
BOCSKAY'S INSURRECTION.

\section{CHAPTER XXIV.}

\section{BOCSKAY'S INSURRECTION.}

The sixteenth century appeared to have multiplied the divergencies between king and nation. The ling was a Catholic, while the majority of the people were Protestants. Feeling hampered by the privileges of the nobility the monarch tried to increase his own prerogatives, ignoring the question of the independence of his dominions. The Hungarians, on the other hand, were enthusiastic defenders of their country's independence, and the king, seeing that they paid homage to the Sultan as well as to himself, trusted them less than his other subjects, and withheld from them the part to which they were entitled. In all its relations with the other Habsburg dominions the king tried to make Hungary occupy a subordinate position.

The fact that the nation desired to make a rigorous attack upon the Turks, whereas the king acted only on the defensive, was another source of friction, and when at last the misery and the hopelessness of the long war had exhausted the nation, and made it long for peace, Rudolf insisted upon a continuance of the war. The king had no money for war upon a large scale, yet he was not willing to make peace.

The dynasty came into collision with the wishes of the people through its divergent interests and its errors, while the wrongs suffered created in the nation such a disposition as offended the king.

It was a great disaster that at such a critical time the throne of Hungary was occupied by a man who was entirely devoid of self-control, and lacking in political 


\section{DEVELOPMENT OF HUNGARIAN I.HBERTY.}

insight, and was a prey to those prepossessions which had brought his forerunners into collision with the nation.

Rudolf would be an interesting study for the psychologist. He had talent and a keen sense of beauty. He took a great interest in the culture of his time, and was a connoisseur in art and an astronomer. He did not lack kindly feeling, but he had not a well-balanced mind. He was nerrous and unable to rome to a decision. His moods fluctuated from day to day. Now he was passionate about something, while the morrow found him perfectly apathetic. He would lave liked to command everybody, though he could not command himself enough to keep from striking his ministers. He jealously guarded his power, but could not use it. He tried to tie evervone's hand, but he himself was unable to act. Ile was full of warlike thoughts, yet timid in time of danger. Although he wished to have a standing army he spent his money in luxury, in this respect forming a great contrast to his contemporary Henry IV. of France, who dressed shabbily in order to spend the money thus saved upon his troops. Rudolf wished to exclude the most suitable elements from a share in the work of government. He was jealous of all the State dignitaries and of his own relatives, but he did not shrink from listening to the secret new conveyed by his confessor, or even br his footmen. He wished to decide the most rital questions, and ret he could not work hard enough to manage even the simplest private affairs. The talents he possessed inclined him to meditation, while for practical life he seemed to have no qualifications whatever.

But just as extreme cold and extreme heat produce in some respects similar results, so remarkable strength and extreme incapacity sometimes lead to similar consequences. Both prompt to daring actions. The strong man faces danger because he loves to brave it, while the other is simply unaware of the danger. Rudolf dis- 


\section{BOCSKAY'S INSURRECTION.}

played the same mental symptoms as Napoleon, especially when his nervous illness was upon him, but that which was caused in the soul of the great emperor by the intoxication of success, in Rudolf was due to the lack of sound judgment. He seemed designed to make absolutism ridiculous, and to reduce it to an absurdity. He wanted to be one to hew out new paths, although he was unable to walk securely even in the beaten track. His whole activity was calculated to fan smouldering discontent into flame. In every one of his dominions the monarch had been forced to concede a share in the work of government to the privileged classes, but Rudolf wished to rule without them, and to do what none of his predecessors had dared to attempt. He was full of Spanish ideas of government, and had an exaggerated notion of the royal dignity. He clesired to control the affairs of his various dominions from a distance, where he dwelt in seclusion, seeing and knowing little of men. At the same time, he threw himself into the Catholic reaction, becoming a tool in the hands of a power whose aims were not identical with his, a power that worked for itself only, and aimed at universal dominion, never caring what became of its instruments.

A ruler who is the slave of his whims, and yet thinks himself a superior being, can easily become by reason of his vanity the tool of a crafty person who approaches him with skilfully rendered homagre. It was natural that the Jesuit influence should triumph over Rudolf. How could those who always watched so keenly the rulers of the various States, miss such an opportunity as presented itself to them in the king's want of mental balance? Such consummate students of human nature had an easy task with Rudolf. They thought their aim was a lofty one, and this deafened them to the roice of conscience, and even to the appeal of their own dignity. When necessary they flattered the king and bore patiently his whims and outbursts and disdainful behaviour. They were so successful that the unhappy monarch declared himself 


\section{DEVELOPMENT OF HUNGARIAN LIBERTY.}

ready to restore the supremacy of Catholicism. After having aroused the political passions of his subjects he placed himself in opposition to their consciences. This he did in all his dominions at once. The policy he pursued in Hungary was only part of his general policy. His enterprise was directed not against the Hungarians but asainst Protestantism, and popular rights. He followed no well-thoughtorut plan, hut was simply carried awa hy his inclinations, which had been fostered by flattery and skilful treatment. His fanaticism and his tyrannical tendencies left no room for the action of sound judement .

The effects of the morbid mental condition of this king were first felt in lansylyania. As he had taken possession of that country in 16;0) by force of arms, he felt that he owed no respect to the country's laws. He simply cancelled the Constitution, and those who had formerly exercised the rights of legislators now could crnly come to their master with petitions. Transylrania was plated under an executive rouncil composed of Germans who acted in atcordance with instructions received from Court.

This would have involved the substitution of bureaucratic and military control for the autonomy of the nobility. Transyliania, sepatrated from the Hungarian State, would have come entirely under the power of the ruler, and an absolutist régime would have begun.

This policy demanded that the people's capacity for resistance should be utterly destroyed. The power of the nobles, no longer protected by the Constitution, was to be broken, a result which could best be secured by organising great German settlements in Transylvania.

The community, mortally hurt in its rights and its national feelings, had also to be attacked on the side of its wealth in order to be entirely conquered. Básta, the cruel governor appointed by Rudolf, declared that the 
right of conquest put an end even to the possessory rights of the individual, and that it was an act of mercy if he left untouched the property of such as did not displease him. Every right of the individual was dependent upon the will of the monarch. Taxes were imposed on the towns and on the individual for the alleged purpose of maintaining the army. What was saved from official rapacity was the prey of the unruly and greedy troops. The army, which had no regular pay, exhausted that unfortunate country by its orcries and plunderings.

To all this misery was added distress of mind due to the propagation of Catholicism by violent means.

After Transylvania the turn of Hungary had to follow. In Hungary there was no pretext for the alteration of the existing system, so that absolutist efforts could not be made with such brutal epenness as in Transplvania, but the tendeney was the same. First there came an atlate upon the wealth of the nobles by means of trumpeclup lawsuits. In this way the ruler sought to destroy one source of the nation's strength, and at the same time to gain money for the treasury. Then a new principle. was established which at one stroke gave enormous wealth to the king. It was declared that lands recovered from the Turks would not he restored to their formor owners, but would belong to the crown.

The Court party tried to destroy the dominant race in Hungary and Transylania, because it was not sufficiently Catholic or sufficiently obedient. The monareh alleged that the towns were his property and that he was entitled to fix their religion as the landowner fixed that of his serfs.

$A$ beginning was made with the town of Kassa. Ceneral Belgiojoso took possession of the Protestant Church there, and gave it to the Catholics. The Protestant pastors and teachers were driven away, the Protestant service was forbidden, and the town's property was seized (1604). When the leading men of the town protested against this treatment, Rudolf bade them cease 


\section{DEVELOPMENT OF HUNGARIAN LIBERTY.}

to complain and renewed the laws against heretics. After the Diet was dissolved, Rudolf, on his own authority, introduced this renewal among the decisions of the Estates.

We have already seen that even in earlier times the kings occasionally altered the decisions of the 1)ict, but what had previously passed almost unnoticed was now done by Rudolf in such a way that the danger inrolved could not be overlooked. Rudolf dealt mortal blows to the legislative system by his increasingly unconstitutional action. Whereas at first he had merely modified in accordance with his own ideas a law actually passed by the Diet, he now frequently inserted in the code laws which the Diet had never dealt with. In this way he created precedents which tended to place legislation entirely in the hands of the king.

Rudolf's tyranny became more and more open. He decided in matters which were entirely beyond his powers and he claimed the validity of law for his decrees. He affected the religious situation in such a way as to work enormous injury to the great majority of the nation. The king destroyed the freedom and the privileges of the Diet by forbidding it to discuss the religious question.

History is full of blunders, the dire results of which dynasties and nations have had to hear, but rarely has any statesman been cruilty of so many mistakes as were made by Rudolf and his advisers. They seemed bent on rousing all the factors of the empire. The towns inclined to the king rather than to the aristocracy, yet it was to the towns that Rudolf dealt the severest blows, thus driving them into the arms of their former opponents. The king was not even clever enough to make use of the rivalry between the various religious denominations. It is possible that the German Lutherans, who had enjoyed toleration longer than any other Protestant sect, 


\section{BOCSKAY'S INSURRECTION.}

might have been willing to leave the Calvinists to the mercy of the Catholics, yet Rudolf began his work of conversion among the Lutherans. Just when he was trying to prepare the way for German supremacy in Hungary, he roused the anger of the Germans by persecuting their faith. It was the result of the king's policy that burgesses and nobles, Calvinists and Lutherans, Germans and Hungarians, were all united against him.

Rudolf also neglected to conclude peace with the Turks, although he knew that he had been at war with them for thirteen years, without any result. The government was impotent, vacillating and corrupt. The lack of money had become very serious. Some time before every thoughtful statesman had protested against the continuance of the Turkish war because of the emptiness of the treasury. Much of the money extorted from the people found its way into the pockets of the officials. The other countries ruled by Rudolf were in a similar condition.

The unfortunate policy of the ruler had brought Hungary face to face with a grave crisis, and had placed the adherents of the western alliance in a difficult position. If they remained faithful to their policy they could only do so at the expense of their freedom, their national existence, and their religious convictions. Even those who hated and feared the Turks, and who saw that Hungary could only hold her place in alliance with the neighbouring Christian power, could not endure the unlawful conduct of Rudolf, which almost amounted to insanity.

One ancient rhronicler wrote of the Hungarians that they hated the Turks so long as the Germans did not anger them. This statement is very near the truth. The Hungarians had always hated their pagan enemies, but when the Germans began to threaten them, body and soul, they were inclined to seek the protection of the Turks.

Rudolf had brought the nation to a state of utter desperation. The people had nothing more to lose, and 


\section{DEVELOPMENT OF HUNGARIAN LIBERTY.}

they acted accordingly. The time of caution and deliberation was past, and the nation risked everything because it could no longer tolerate the existing situation. The Hungarians had borne much because they felt that they needed the protection of the Habsburgs, but now the protecting hand was strangling them. A continuance of Rudolf's tyranny would have meant certain death, so, although the struggle involved terrible dangers, yet it gave at least the hope of deliverance.

Dramas are generally built up on the basis of a conflict between a good and an evil element. In this case real life provided such a conflict. Rudolf was the eril element, whose actions had made a sanguinary contest unaroidable, and Bocsliay was the hero who saved the situation and killed the Hydra.

Bocsliay may justly be considered a great man in the fullest sense of the word. He possessed strength and self-control, the talent necessary to achiere success and to make use of the success when gained, pure intentions and a great mind, calm deliberation, and promptness in action. He could be serere when necessary. He had a strong will, and was not dependent upon the advice of others, yet he saw so clearly the adrantages of freedom and understood so well the requirements of his own part that as a ruler he was thoroughly constitutional. $\mathrm{He}$ discussed every question with the Diet. In many matters he did not even express an opinion in order to waken the sense of responsibility in the Estates. He is undoubtedly one of the most striking figures in Hungarian history. All the great results which he achieved were due to his own merits. His successes were at the same time the successes of the nation. He fought for a sacred cause, and he fought for it with decision, with power and with success. In a critical time, among grave dangers, he kept at his post, and saved his country.

The circumstances of Bocskay's life helped to develop his talents as a statesman. He had large dominions, the management of which was the best pos- 


\section{BOCSKAY'S INSURRECTION.}

sible training for the work of government in such a restless age. At that time the great landowners had to perform military, administrative, judicial, and diplomatic duties. Being uncle and councillor to Sigismund Bathory, Bocskay became acquainted with the eastern portion of the country, and with its traditions. He was also acquainted with Rudolf's Court, and could study the governments in Vienna and Prague. He had possessions both in Transylvania and in Hungary. He was no particularist, and his view extended beyond provincial bounds over the whole of Europe. He lived for the whole Hungarian nation.

When speaking of Szapolyai we mentioned the great disadvantage of an aristocratic organisation, the possibility, namely, that an important part might fall to a man not great enough for it. On the other hand much good may result from a privileged position. If it falls to the lot of a suitable man he can achieve greater and better results than would otherwise be possible. He can develop his talents more easily, can become many-sided, and can acquire the art of leading men more completely than he could under different circumstances. It was certainly a great advantage to his nation that Bocskay was born in the purple.

Bocskay repeated in himself the history of the nation. He had suffered much and long, and only took up arms when the tyrant began to threaten his very existence (1604).

Does this indicate selfishness? Did he risk his own welfare for that of the country, or his country for his own interests? Unfortunately, history often shows us men who bear everything so long as they themselves are in danger, but who, as soon as their own interests are threatened, try to set everything on fire. W Was Bocskay such a man? Before the imperial armies attacked him, Bocskay was in communication with the persecuted Hungarians, as well as with the Turks. He felt that the situation was unbearable, and was thinking of resistance. 


\section{DEVELOPMENT OF HUNGARIAN LIBERTY.}

But he was not the man to invite danger. He was in favour of the western alliance, and an enemy of the Turks. He did not believe that the Hungarians could give him any help, he had much to lose, and he thought that so long as he was not deprived of his castles and dominions he might safely watch the development of events. He was no revolutionary by nature, and was only made so by circumstances.

To all the previous offences of which Rudolf was guilty, a new wrong was added. The imperial army attacked Bocskay on the ground of mere suspicion, without any pretence of judicial proceedings, but just like a band of robbers. Bocskay was justified in saying that it was the king's own troops and guns that forced him to be disloyal.

The moment chosen by Bocskay to unfurl his banner does not therefore give any indication of selfishness. Like the nation itself he had a hundred reasons to abstain from war, and he only took up arms when the situation began to prove threatening to his power, which was the most important means of national resistance to the royal tyranny.

In the struggle between Rudolf and Bocskay it was Rudolf who took the offensive, while Bocskay maintained politically as well as physically a defensive attitude.

If insurrection is ever justifiable then the rising of bocskay was so. It was right because it had become a national necessity, and because it only sought what "as attainable, and was able to moderate itself. It was legal too, since it was in accordance with the Golden Bull, and was a resistance to attacks made upon the Constitution and upon the rights of individuals.

What was the policy of Bocskay? The fundamental principle to which he adhered was that of Hungary's alliance with the west. In had always advised Sigismund Bathory to unite with the west in resistance to the Turks. His first military laurels were won in a war against the 


\section{BOCSKAY'S INSURRECTION.}

Turks in Wallachia. He achieved great successes. The Sultan offered him the Hungarian crown, and the most warlike among his adherents also wished to raise him to the throne. It would have been easy to win public support for the conception of a national monarchy, as the nation had begun to see that it could never thrive under the Habsburgs. Rudolf was not thought fit to rule even by the members of his own family. His own brothers tried to take away his crown. Why should the Hungarians have been more loyal? Tet Bocskay did not wish to dethrone Rudolf. He refused the crown offered him by the Sultan. It was a pure and lofty political aim for which he fought, and not rank or any other personal advantage. He was ambitious, like Martinuzzi, but his ambitions were lawful and useful. He never broke through the restraints imposed by the public interest. He did not vary his aims in accordance with the fluctuating fortunes of war: neither by men nor by events did he allow himself to be driven hither or thither; his increasing successes did not augment his ambitions or his demands, and every action was directed towards his final aim. Even the prospect of the crown did not make him swerve from the path which he had chosen. He knew that if he accepted it he would have to throw in his lot definitely with the Turks, and this he considered inadvisable. He looked for the future welfare of the nation to the western alliance, which, under the circumstances, could only be assured by accepting the Habsburgs as rulers. On the other hand he clung tenaciously to the idea of an independent Hungarian State, and to the law which assured that. His attack was directed not against Rudolf only, but against the whole system which had been threatening Hungary ever since the battle of Mohács. He did not desire to deprive the Habsburgs of the crown; he only sought to compel them to pursue a policy which would satisfy the reasonable demands of the Hungarians. He endeavoured to establish a Hungarian State which should have the support of the other Habs- 


\section{DEVELOPMENT OF HUNGARIAN LIBERTY.}

burg dominions but which should be entirely autonomous. He devised no new legal scheme to solve the problem of community of interests between Hungary and the other Habsburg territories. His was the traditional Hungarian standpoint. He wished to place the common efforts under Hungarian leadership.

Bocskay's other great aim was to win religious liberty. While in his politics he was dominated by a conservative idea and fought for ancient Hungarian rights, in the matter of religion he took a great step towards the ideas of a later age, and abandoned the demand for religious uniformity. It is to his lasting credit that he did not seek to establish the supremacy of Protestantism, but inscribed the word toleration on his banner. He himself was a zealous Calvinist, and the majority of the nation was also Protestant, yet he did not persecute the Catholics even in the hour of his victories. He may have belonged to the few who even in that age grasped the truth that in matters of conscience even mistakes deserve our respect, and that to inflict punishment for them is cruelly unjust. He also realised that the nation could only endure if the different denominations dwelt together in peace. As a politician Bocskay saw that the cause of national freedom needed the help of every citizen.

The roval party complained that Bocskay and his followers tried to attach both Catholics and Protestants to themselves, that they questioned no man as to his religion, and passed no laws against anyone's creed, and that Bocskay gave letters of protection even to Catholic priests. Could there be a more splendid testimonial to Bocskay and the nation than this complaint?

How different was the attitude of another champion of Protestantism, William of Orange. He lost the Catholic portions of the western provinces, which accepted Spanish rule again, because the Dutch sought to found an exclusively Protestant State. The Hungarians showed much more tolerance than the Dutch, al- 


\section{BOCSKAY'S INSURRECTION.}

though the latter were famous for their enlightenment, and although at first Catholics and Protestants had fought side by side against tyranny.

Bocskay sought to place the great interests for which he fought under the protection of law. He wished the increasing foreign influence to be stopped by law and that religious liberty should have some better safeguard than mere promises. Only on such conditions was he ready to make peace.

Law, by itself however, could not defend the nation's interests. Living powers were needed to enforce the law. Such a power Bocskay sought in the independence of the eastern portion of the country, the creation of Martinuzzi and Stephen Báthory. Bocskay really had no free choice in this matter. As soon as he unfurled the banner of insurrection his programme could be nothing else than the autonomy of Transylvania. Historical development had determined the path which it was necessary to take. Although the independence of Transylvania had for some time been in abeyance, it was bound to revive. All the misery that followed the union with the western portion of the country woke a yearning for separation in the hearts of the inhabitants during Básta's reign of terror.

The protection of the Sultan promised more certain peace than could be expected from Rudolf. The union of the two parts of the country would only have been natural if the Turks had been conquered, but the nation did not dare to hope for this after the long and unsuccessful war. The first condition of Turkish support was the separation of Transylvania from the dominions of the Habsburgs. The Hungarian Constitution was a matter of indifference to the Turks: their aim was to take away as great a part of Hungary as possible from the Habsburgs. They were only ready to fight on behalf of a sovereign Transylwania under their protection. They would not have allowed its union with western Hungary.

Until the reign of terror of Básta, Bocskay does not 
appear to have been in favour of the separation of Transylvania. He had negotiated the contract by which Sigismund Báthory resigned his principality in favour of Rudolf. Bocskay wished to unite the nation, which was still free, in the service of one common aim. He now set a new aim for the common effort. Instead of war against the Turks, it was the defence of the Constitution to which he desired to derote all the nation's strength, and the accomplishment of this aim demanded not the union of the two parts of the country, but that Transylvania should be separate, protected by the northern districts, and enabled to pursue a national policy.

This idea was clearly expressed in Bocskay's will. "While the Hungarian throne is occupied by a powerful foreign ruler, Transylvania must be governed by a national ruler in order to defend Hungary and religious liberty. Let Transylvania remain in connection with the realm of St. Stephen, let it be complementary to that realm, but it must have independent military and political power in order that it may throw its sword into the scale in the interest of the Hungarian nation."

Bocskay prepared a great future for Transylvania. He fitted it to fulfil a great national mission. He wished it to live not for itself only but also for the other portions of the Hungarian nation, and to be a counterpoise to Viennese influence. In his will, so full of wisdom, he wrote "that they (Transylvania and Hungary) should stand by one another in every emergency, it being a wellknown truth that by discord even great empires are ruined, while by unity small ones become great."

This was why he attached so much importance to the throne of Transylvania, considering its maintenance as the sine qua non of peace. He also accepted the dukedom of Hungary (1605), but only temporarily in the interest of the war: he never attempted to retain it on the conclusion of peace.

Bocskay recommended Homonnay as his successor upon the throne of Transylvania, because he trusted that 
as Homonnay came from Hungary he would try to maintain the co-operation of the two parts of the country.

The policy of Bocskay had a decisive influence upon the development of the Hungarian Constitution. It was Bocskay who, after the long torpor which followed the battle of Mohács, roused the Hungarians, and led them to war against royal tyranny. The struggle did not, however, seem calculated to be of much service to the Constitution. Its purpose was the defence of national independence, and not the establishment of a new governmental system. What was demanded was that the old laws should be enforced, and not that a new constitution should be created. If among the difficult circumstances of the time the nation could assure its independence it would achieve more than it dared to hope. What the nation desired was to exist, not to modify the relations of the various factors of the State. Bocskay's policy did not demand the increase of the power of the Diet. It was the diplomatic and military action of Transylvania that could save the country, and not the influence of the legislators of Hungary proper upon the government.

The situation would have been quite different if the old united State had been maintained. If Bocskay had been not Prince of Transylvania, but a nobleman of Hungary, and if Transylvania had been a part of the Hungarian State, the war would have raised the Diet above the king, and Bocskay could only have made the results of his victory secure by increasing the authority of the Diet.

Bocskay had to abandon his former policy with regard to the Turks. As sonn as he drew his sword against Rudolf he had to join the Turks, even though he regarded them as his enemies. He cannot be reproached for this, because he acted under the pressure of necessity; moreover, he considered his alliance with the Turks as a passing episode, and he so shaped his policy that he could easily free himself from them. Even when 


\section{DEVELOPMENT OF HUNGARIAN LIBERTY.}

allying himself with the Turks Bocskay did not lose sight of the interests of the Hungarian race. He had changed his attitude but not his aims, and still sought to serve his race by his Transylvanian policy. He was careful above all to preserve the nation from any harm that such an alliance might cause. He inserted in the treaty the condition that the Turks might attack only the non-Hungarian dominions of the Habsburgs, and might not take any Hungarian territory. In this way the Turks could compel Rudolf to make peace without shedding Hungarian blood.

The Sultan did not keep to his promise, but continued his wars in Hungary, and Bocskay had to be satisfied with the declaration of the Sultan that he would only annex the fortresses near the Austrian frontier, and such parts of Hungary as had formerly belonged to him. In addition to this, Bocskay had to promise to hand over the towns of Jen" and Lippa.

The inherent fault of an alliance with the Turks had always been that he who needed their help had to pay for it with the soil of his country. This alone was enough to urge Bocskay to bring about a compromise with the king. He had always been an enemy of the Turks. As long as he could he fought against them, and when he could do so no longer he became an adrocate of peace, because peace alone could prevent the internal crisis of which the Turks would assuredly have taken advantage. That Bocskay insisted upon was that peace should not be concluded without him. He demanded from Rudolf that he should not treat of peace with the Turks without his intermediation. He also exacted a promise from the Porte not to confer in his absence with the king's plenipotentiary.

Bocskay also tried to find allies in the west, and to place the Constitution under international protection. Rudolf's tyranny, as well as the Catholic reaction, had created unrest in all the dominions of the Emperor. The leading elements in the hereditary Habsburg territories 


\section{BOCSKAY'S INSURRECTION.}

felt sympathy with the aims of Bocskay, who therefore tried to use their support on behalf of the compromise to be effected. He wished to see freedom defended by an alliance of all the peoples beneath the sceptre of the Habsburgs.

It is not surprising that this policy brought the various nations into Bocskay's camp. With the exception of a few individuals everybody joined him, magnates, gentry and burgesses alike. The Protestants were his adherents, and so were some of the Catholics, because of the strength in them of the national sentiment. The few great nobles who still sided with the king knew so well that public opinion was against them that they asked to be protected by foreign soldiers.

Rudolf could not reckon upon the Austrians or Bohemians. They also were glad to see the downfall of a system which they hated. The Spaniards were occupied in France and in the Netherlands, while in the German Empire the Protestants were as strong as the Catholics, so that Rudolf could not expect much help from these sources. Success against Bocskay and the Turks was therefore impossible. While the impotent personality of Rudolf paralysed even the forces that were at his disposal, Bocskay was an excellent organiser. The inhabitants who had been expelled by the Turks, and who, in consequence of their misery, lived by robbery, he received under his banners, and by giving them land he attached them again to the country from which they had almost drifted away. By raising them to the ranks of the gentry he made them defenders of the Constitution. He gave inhabitants to the abandoned districts, and houses to the wandering outlaws, and found the way to transform the enemies of order into its defenders. His splendid talents, as well as circumstances, helped Bocskay to victory, and when victory was gained he pointed the way to peace. He kept to the path of moderation, that path which it is so difficult to tread in times of revolution. Bocskay experienced to the full its difficulty. 


\section{DEVELOPMENT OF HUNGARIAN LIBERTY.}

From two sides he was attacked by his own adherents, and he had to have a few of his brave soldiers executed in order to defend peace from those who lived by war.

Illésházy was called a traitor and a German hound by the extremists, who wished to lill him because he did not side with thuse who thought themselves the only true patriots, and looked upon moderation as unpatriotic. Bocshay, however, honoured Illésházy with his confidence, and entrusted him with a prominent part in the negotiation of a peace treaty. He did not withold his favours even when he found that Illésházy had been too conciliatory, because he knew that he had done good work, but he did not allow himself to be led even by that powerful and wise adherent of his party, and he declared that the conditions of peace as laid down by Illésházy were not acceptable.

Bocskay considered peace so important that for its sake he would have been satisfied even with less than he actually achieved. He felt the truth of the remark that " if we fight too much for our freedom there will be no country left for the purpose." This was why the great Prince Bocskay was more conciliatory, more "German " than the majority of his party. He who had most to gain by inconsiderately using his successes for his own benefit was the most moderate in his hour of triumph. He only demanded what he thought essential to the defence of great national interests, and therefore he attained his aim.

The Habsburgs themselves could not but see that the conditions demanded by Bocskay were less dangerous to themselves than a continuance of the war, although those conditions limited their power. The dynasty itself urged Rudolf to come to terms. The peace of Vienna and that of Zsitvatorok (1606) gave to the nation and to Bocskay all that they had been fighting for.

The Vienna treaty guaranteed Hungary's independence and religious liberty, and Bocskay's rule over Transylvania and northern Hungary. The fulfilment of 


\section{BOCSKAY'S INSURRECTION.}

these conditions was guaranteed by the Austrian Estates. The peace treaty with the Turks was the best that the king of Hungary had concluded since Mohács. The yearly tribute was stopped, and the Sultan and the king figured in the treaty as parties of equal standing. The arrangement between Bocsliay and the dynasty was included in the treaty with the Turks, so that the Sultan became a guarantee of its being carried out.

Bocskay was not destined to enjoy the fruit of his labours. Hardly was his work completed when he died (1606). Those whom he had either conquered or kept under restraint, revolted against the new order, the strongest support of which had fallen, and the task fell to Rudolf of upholding all that he had wished to destroy.

Rudolf's faults had paved the way to Bocskay's success, and now his new mistakes helped the people to further victories. Hungarian liberty has hardly ever had worse enemies than Rudolf and his Court, yet scarcely anyone has been of more service to the cause than they.

Rudolf was not inclined to comply with the terms of the peace treaty. Bocskay's soldiers feared for the safety of the great national privileges which the treaty had guaranteed on account of Rudolf's ill-will, so they returned to their extreme policy of separation, a tendency from which they had only been diverted by the strong hand of Bocskay.

The Turlis also prepared for war. Rudolf's madness was likely to set the whole country on fire again, and thus serve the aims of the extreme revolutionary party. If they had to fight again it was doubtful whether the desire for separation would not outweigh all other considerations. Rudolf himself stood in opposition to the vital interests of the Habsburg dynasty. The strong instinct of self-preservation to which this family owed its position, banished all considerations of subordination or relationship, and the Habsburg archdukes began to think of the defence of their dynastic interests.

Even in Bocskay's time peace had been brought 


\section{DEVELOPMENT OF HUNGARIAN LIBERTY.}

about through the intermediation of some of the archdukes. Now they stood up in defence of their own achievement, and under the leadership of the king's brother, the archduke Matthias, they formed an alliance with the Hungarian Estates. The Austrian Estates had manifested sympathy for the Hungarian cause in the past, for Bocskay had fought against the same evils that afflicted them. Rudolf's new acts of aggression emphasised this community of interests still more, and an alliance with the archduke Matthias, and with the Hungarians, awoke in them great hopes of acquiring for themselves all that the Hungarians had fought for. Thus an alliance of the Austrian, Moravian and Hungarian Estates was concluded under the leadership of Matthias in defence of the Vienna and Zsitvatorok treaties.

The alliance was directed against Rudolf, and it won an easy victory. Rudolf abdicated the thrones of the countries which had become his enemies, and they elected Matthias in his stead (1608).

The Hungarians were the first to make Matthias their king. Matthias II. could not resist the current of events which had carried him to the throne. He had to reap the consequences of his situation. Events had made him the champion of Protestantism and of the Estates. He had acted against his own convictions and desires, but he had taken the only possible way of saving the dynasty. Now he had to pay for the advantage he had gained, and to make such concessions as put an end not only to Rudolf's illegalities, but also destroyed the results of the policy which his predecessors had followed. Protestantism and the Estates won a complete victory over Catholicism and Absolutism.

What the king had to concede to the Hungarians he had also to grant to his other dominions. Bohemia alone remained faithful to Rudolf, but eren that country demanded very great concessions in return for its loyalty.

Let us glance at some of the results which had been achieved. 


\section{BOCSKAY'S INSURRECTION.}

The Vienna peace treaty and the Diets of Matthias 11. meant the close of an epoch which had lasted for seventy-five years, and the commencement of a new era. The most important event of the moment was the substitution of Matthias for Rudolf on the throne of Hungary. Even legally this result was very important, as it meant a victory over the dynasty. The symbol of power, St. Stephen's crown, was brought back to Hungary. Religious liberty had triumphed. It was declared that in filling the various public offices, religion was not to be considered. Every denomination was to be controlled by its own governing body, and the right of free religious worship was granted even to the serfs. An effort was made to save the government from being too much influenced by the Catholic priests. The national welfare demanded this. The excessive influence of a denomination which constituted a minority of the people was harmful and abnormal. The events of recent years had shown that the priesthood could not be trusted in the matter of the people's liberties. Several of the bishops vere excluded from the royal council, and a law was passed to the effect that the treasurer should always be a Protestant.

At first the extreme Protestants made excessive demands, but more moderate counsels ultimately prevailed. Against the Jesuits, however, the Protestants showed some rigour. The order lost the right of holding landed property in Hungary. It is not surprising that the Hungarians were less tolerant towards the Jesuits than to other religious bodies. It was most important from a national point of view that those highly cultured and untiring apostles of Catholicism, who were not at all scrupulous as to the means they employed, should not arouse in the Catholics of Hungary the aggressive spirit with which they themselves were animated. Hostility to them was demanded not alone by the interests of Protestantism, but by those of the harmony of the whole religious world. Toleration and liberty can sometimes 
be defended only by means that are contradictory to the spirit of tolerance and freedom.

Another result was that after forty-five years the nation again elected a Palatine. During the time of the Habsburgs in Mungary, the country had only once had a Palatine, and now that the election took place, even in that event religious equality was exemplified. It was arranged that the ling should select two men from the Catholics, and two from the Protestants, and then the Estates were to elect as Palatine one of the four candidates. In this way the king could prevent any one of his decided adversaries from becoming the head of the executive, and yet the Palatine would receive his dignity at the hands of the Estates.

The standing of the Palatine was what it had been before; he was to be at the head of the government. Side by side with him the royal council was to retain all its rights. The Banus of Croatia also was to retain his former powers. In control of the country's finances a treasurer was to be appointed in place of the former bureaucratic body. The independence of the State was further secured by the law that public offices should only be given to Hungarian citizens. All affairs of State were to be managed by a Hungarian government, and in clealing with those matters the king should only be advised by Hungarians: no foreigners were to interfere with the country's affairs. The nation's finances were to be quite independent of the Austrian Treasury. None of the country's revenues were to be handled by foreigners. Chancellor and Treasurer were to be elected from the king's Hungarian council. This assured the influence of the Hungarian Estates positively, whereas the exclusion of a foreign council merely acted negatively. The growing foreign influence which had proved so injurious to the country was destroyed.

Tuch harm had also resulted from learing unfilled many important public posts. This neglect was now forbidden by law.

The most difficult problem was the satisfactory settle- 


\section{BOCSKAY'S INSURRECTION.}

ment of military matters. One circumstance, however, made the work of legislators somewhat easier, namely, the peace concluded with the Porte. The foreign troops were sent home so that the difficult task of reconciling their presence with Hungarian interests was at an end. A law was passed to the effect that the king might not commence war without the consent of the Estates, nor might he call in foreign troops, so that the situation of the foreign soldiers did not constitute a problem of practical politics.

The question of the frontier fortresses was more difficult. Foreign pecuniary support was necessary, yet the Hungarians were afraid of the foreign garrisons, because they were not so trustworthy as Hungarian troops as regards foreign enemies, while the internal foes of Hungary could have no stronger support than the foreign troops. Legislators, therefore, would have liked to use the foreign money for the maintenance of Hungarian garrisons, and it was a great proof of their capacity that on paper at least they actually attained this result. A law was passed that the captains of the fortresses must be Hungarians, with the exception of the captain of Györ. but even he must have a Hungarian lieutenant. The garrisons also must be Hungarians. In spite of this, pecuniary help towards the payment of the soldiers and the maintenance of the fortresses was demanded. The captains were to be chosen by the Hungarian council. The one foreign officer, the commander of Györ, was placed under the direction of the Palatine.

The king was to reside in the country, or if he were obliged to leave it, the Palatine and the Council were to have full powers.

The organisation of the Council remained unaltered. No effort was made to place the executive in a position of dependence upon the Estates. The aim was rather to make the Estates independent of the king. This was shown by the laws passed concerning the election of the Palatine, and also by the paragraph relating to the ques- 


\section{DEVELOPMENT OF HUNGARIAN LIBER'TY.}

tion who were entitled to take part in the meeting of the Estates. This had not been clearly settled before. Now the omission was rectified, and the king's hands were bound more strongly than they could have been by mere custom. The laws passed embodied no new principles, but merely confirmed the existing order. It was declared that the country had four orders, the prelates, the barons, the gentry, and the burgesses of the free towns. The king must summon these to the meetings of the Diet. Others, however, he must not summon. This shows clearly that the formation of the legislative body was not a prerogative of the king, and could only be decided by law. The system of two houses was accepted.

Questions of individual liberty were not neglected. Nobody could be condemned without lawful trial, or was obliged to obey any illegal command.

One more decision is worth mentioning, that was intended to put an end to a great fault in the existing law which acted very disadvantageously to the Hungarian race and the national cause. The new law opened to the Hungarians the "free royal towns," and granted them the right to own houses in the towns, and to become members of the municipality. It was only then that members of the dominant race attained equality with the foreign burgesses in their own country.

All the problems which had arisen during the Habsburg régime were solved in a manner favourable to the nation.

Before continuing the narration of events, let us review the principal causes of the great results secured, as thisbook seeks to give the reasons for Hungary's freedom.

The fate of a country is often powerfully influenced by the political situation of its neighbours. Foreign events often determine the course of development of internal affairs. This was the cause with Hungary. Every event was influenced by the circumstance that in the sixteenth century the Habsburg dynasty had to grapple with 


\section{BOCSKAY'S INSURRECTION.}

ever increasing difficulties. The power of the dynasty which, in the time of Charles $V$., appeared to be growing to enormous dimensions, began to decrease even during the lifetime of that monarch. At the commencement of the century the dynasty had aimed at the leadership of the whole of Europe, while at the end of the same century its enemies were looking forward to its final downfall.

This situation of the dynasty was the chief cause of Hungary's freedom. The Habsburgs, in their difficult position, were compelled to abandon many of their plans and to be satisfied with the defence of what was absolutely indispensable to their future welfare. It was not very important to them what happened in Hungary. Their dynastic interests merely demanded that St. Stephen's crown should remain in their possession, together with so much Hungarian territory as would suffice to ward off Turkish attacks. They need Hungary merely in order to defend Germany and the west. Their interest and their duty alike demanded that the Turks should be driven out of the country, but they did not dare to embark on this enterprise with the energy which alone could promise success.

With regard to the Protestants their attitude was the same.

It was to the interest of the monarchs to refrain from exerting themselves in order to destroy the Hungarian Constitution. They objected strongly to many privileges of the Estates which hampered their own freedom of action. They would have liked to make use of the money and the armed forces of Hungary in such ways and in such places as their aims required, but the Habsburgs would have committed a great political blunder if they had risked an open conflict on this account.

The Hungarian nation had become weaker, but it had preserved its love of liberty, and events had even strengthened that sentiment. The king could not affect the internal organisation of the country, and the general trend of events had increased the decentralisation which 


\section{DEVELOPMENT OF HUNGARIAN LIBERTY.}

had previously been considerable. As the monarchy could not win the heart of the nation, its victory could unly have been won in open conflict with the people. Absolutism could only have been achieved with the aid of foreign forces which should effect the subjugation of the Hungarians. This would have meant a violent conflict in which the Habsburgs were more likely to lose than to gain, since the nation might have turned its whole power against them. The war that would have resulted could only have benefited Transylvania, and the Sultan under whose protection that principality stood. Thus the Sultan, the worst despot in the world, was involuntarily the safeguard of the Hungarian Constitution. The absolutist efforts of the Habsburss were moderated by anxiety lest a violent régime would make the Crescent supreme over Hungary. If the Habsburgs had tried to annihilate the Hungarian Constitution they might easily have lost the whole country, and have been driven to such straits to defend themselves as would have made their western policy impossible. Against the Turks or the Protestants they could have reckoned on foreign assistance, but who would support them in a struggle against the privileges of the leading classes in the nation? Certainly not the Austrian Estates, who sympathised with the Hungarians. The kings realised that although the Constitution was disadvantageous to them they must not seek to destroy it by violent means. None of them made the attempt until Rudolf became king.

Rudolf was the first Habsburg king of Hungary who was blind to his own interests, but even this blindness proved farourable to the Hungarian cause. At the time of Bocskay's rising the nation felt that it would lose all if it submitted; the dynasty, on the other hand, saw that it would lose much more by not giving in than it could possibly hope to gain. This made the triumph of the Hungarians comparatively easy, especially as they did not demand separation, and were moderate even in the moment of victory. The dynasty was divided, and the 


\section{BOCSKAY'S INSURRECTION.}

weak-minded Rudolf was isolated. The good sense of the Hungarians awoke the good sense of the rest of the Habsburgs, and it became possible to defend the Constitution without breaking the dynasty's power. The nation did not need to embark on such desperate struggles as would have been inevitable if the Habsburgs had threatened its very existence.

The policy of the earlier Habsburg kings was more dangerous than the open violence of Rudolf. They ignored many of the laws; matters connected with war, foreign policy, and finance, had been entrusted to foreigners; but otherwise they showed goodwill towards the nation. They refrained from violent actions, and if they had been more skilful in managing the Hungarians, and had spent more time in the country, if they had made a wiser use of the Hungarian elements of the nation, yielding them some part on the stage of European politics, perhaps in time they might have changed the disposition of the nation, and made it accept their system. The Turkish danger was so great that no one would have dared to destroy, by taking up arms, what little security the terrible enemy had left to the nation. The people would gradually have become accustomed to the absolute power of the Habsburgs. It was Rudolf who saved the nation from this fate by presenting absolutism in its most repulsive aspect. The nation suddenly perceived towards what an abyss it was moving. It was roused from its apathy, and this happened at a time when the Habsburgs were least able to wage the war to which they had forced the nation, while Hungary possessed eminent statesmen.

Wiser policy and better leadership gave the adran. tage in the struggle to the Hungarians.

The sixteenth century had not brought final disaster to Hungary, but the nation's power of resistance had been diminishing. Annexation was not actually accomplished but the way was prepared for it. In the first decade of the seventeenth century, however, freedom was saved by the ill-judged attack of a luckless hand. When resis- 


\section{DEVELOPMENT OF HUNGARIAN LIBERTY.}

tance became necessary the nation did not once transgress the limits of lawful action, and it was victorious because it did not seek to break the power of the dynasty, which it needed, and the downfall of which would have dragged the nation itself to destruction.

The name of Básta will ever remain odious on account of the man's mean and brutish cruelty in Transylvania. His bad fame made more difficult the situation of those who afterwards served the same cause as he had served, although with different convictions and different intentions. That the impression should be still greater, fate had placed beside the hateful Básta the radiant figure of Bocskay, the new type of a national hero. Next to the sreat conquerors of the Turks, Zrinyi and Dobó, or rather in their place, we see the heroes who fought for freedom. These begin to occupy the thoughts of the people. National idealism finds its nourishment in the struggles for freedom instead of in the wars against the Turks. Patriotism came to be more and more identified in the minds of the people with belonging to the party of opposition. In every wrong step of the dynasty they seemed to recognise the system of Básta and Rudolf 11 . Confidence in the occupant of the throne steadily diminished. The foreign origin of the dynasty and the fluctuating policy of the nation had made impossible from the beginning that co-operation which was so necessary to both parties.

Rudolf's absolutist and romanising attempts, which stirred the nation's soul to its depths, brought on the ultimate collision. Básta, and in later times, Caraffa and Haynau, have done the dynasty far more harm than Bocskay, Rákóczi, and Kossuth.

At the commencement of the seventeenth century the nation faced a very uncertain future. The path of progress was likely to open before it only if the nation could become one with its ruler, and if, in hearty co-operation with him, it first regained its lost territory, and then turned its attention to the country's internal affairs. 


\section{BOCSKAY'S INSURRECTION.}

Was there any hope of such a development? The question was whether the peace concluded in Bocskay's time was a sincere peace, and such as could form the starting point of a new career of progress for the nation. Upon the answer to this question the fate of Hungary depended. 


\section{CHAPTER XXV.}

\section{POLITICAL AND RELIGIOUS DIFFERENCES DURING THE REIGN OF MATTHIAS II. (1608-1619).}

The nation's leaders, after the death of Bocskay, were Illésházy and Thurzó. One followed the other in the Palatinate, and they were both thoughtful, circumspect, and just men. It was not their fault if they did not achieve success.

At the commencement of his reign Matthias was much troubled by the Austrian Protestants, who appealed to the Hungarians for support. The interests of the Protestants in both countries were common, but neither Illésházy nor Thurzó wished the Hungarians to turn against their king for the sake of a foreign people. Both men were true statesmen in their wise moderation. They saw that the greatest interest of their nation lay in a good understanding with the king, and in defence of this interest they were ready to risk their popularity.

As we have seen, some of Bocskay's adherents turned against Illésházy, thinking him too royalist to be a good patriot. His very life was in danger. Later on, he stood up for King Matthias, and advocated his coronation. But he was not by any means servile. He was a loyal subject of his king, yet he was ready to take up arms against him when the king thought himself free from his constitutional obligations. He told the king that he must be careful to retain the sympathy of his subjects, for they could easily find another ruler whereas he could not find another country. He strongly con- 


\section{THE REIGN OF MATTHIAS II.}

demned the unlawful deeds of Matthias. He had defended the king before the nation, but he also defended the nation before the king.

Thurzó was a man of the same stamp. He also played the difficult part of mediator. He had not been entirely one with Bocskay. His dominions lay near the Austrian frontier, and therefore, like Illésházy, he had to take thought concerning his own interests. But even in the Emperor's camp he truly served the nation. He was its safeguard from the excesses of both ruler and people. Therefore, he was assailed on all sides, but in spite of this both nation and ruler needed him, and found it wise to follow his advice.

Illésházy and Thurzó were model Hungarian statesmen in that sad time when people and ruler were not united, although their interests demanded that they should be, yet they could not achieve their aim. They should have governed Hungary, together with the king, entirely excluding foreign influences. Their duty, their deepest clesire, the principal aim of their policy, was the restoration of an independent Hungarian government. This purpose, however, clashed with the intentions of the king.

Illésházy had been the first to conceive the idea of elevating Matthias to the throne. He was the man to whom Matthias owed most, yet the king did not entirely trust even Illésházy. Naturally, religion was a barrier between them. 'The king's real minister was Khlesl, who knew the king's thoughts, and directed his actions. Matthias managed even Hungarian affairs according to the advice of Khlesl, although that prelate was not attached to Hungary either by blood or by his office.

Like his predecessors, the king regarded the Court Council as his real governing body. This explains why his policy had not a national basis. Matthias did not seek the guarantee of his power in the contentment of his Hungarian subjects, but in the increasing number of foreigners living in Hungary. The Hungarians had roluntarily invested him with his royal dignity, yet he 


\section{DEVELOPMENT OF HUNGARIAN LIBERTY.}

did not trust them. His fundamental ideas are clearly expressed in his actions and his letters. When, in the year 1614, he seemed to wish to make war with the Turks, he wrote to the Archduke Albert that the Turkish war was a mere pretext, but " the service of God and the maintenance of our dynasty are the main reasons." The war would have given him an opportunity of bringing a foreign arny into Hungary, and so of confirming his rule. When this scheme was frustrated he began to approach the Turks, hoping with their help to achieve his aim. It was the Sultan who suggested that Matthias should place foreign soldiers in the fortresses instead of Hungarians. On this subject Matthias wrote to the Archduke Ferdinand, and his words give some insight into his ideas, and explain better than volumes could do, the tragedy which is called the history of Hungary.

The interesting letter begins with the statement that the offer of the Turks is an insult to the whole nation. IVe see then that although Matthias thus regarded the offer he was ready to accept it. He says that he sees the hand of God in the circumstance that the Sultan himself wishes to abolish the laws passed in Bocskay's time. "In this way the German nation, upon which the Hungarians look down so much that they will not suffer German soldiers in their country even for the purpose of their own defence, will be raised again to the dignity due to it." This alone would be reason enough for using this "excellent opportunity." "The Hungarians," he continues, "invent such harmful devices in order to ensure free election everywhere, that we cannot use better means than the substitution of Germans for Hungarians. The Hungarians are now poor and weak, and they cannot expect help from other countries, so they will have to submit." Then he goes on to say that he could not rule over Transylvania unless he had German troops near its frontiers.

It is only with an aching heart that a Hungarian statesman can read these lines. Every word explains 


\section{THE REIGN OF MATTHIAS II.}

some of the unspeakable sufferings which the nation has had to endure, and reveals the fundamental principles of a fatal governing system.

Cuvier could reconstruct the whole body of an animal from a single bone. Similarly, the whole system of Matthias could be reconstructed with the aid of this letter. The man who wrote of the Hungarians that "they invent harmful devices" could not intend to carry out the laws which placed the power in their hands, and could but rely upon foreign support.

Matthias was placed by his political convictions in opposition to the nation and its rights. He made promises which he did not regard as justifiable. He could not really approve of the concessions which he had made. If he sided with the nation against his own brother it was because he thought that a better future awaited his dynasty, and if he could content the nation and the Protestants it was solely because he thought it advisable to submit to the inevitable.

Seemingly the Vienna treaty was the foundation of a union stronger than had previously existed, because Matthias, before being crowned, had fought for the new order against the head of his house, the Emperor, and it was to the triumph of the new order that he owed his throne. But in reality even this new compact was just like the former one. The nation's victory had created a very difficult situation for the dynasty. The Habsburgs could not maintain their prestige if their dominions were ruled not by them but by the Estates, who in many respects pursued an entirely different policy from their own.

The attitude of the Hungarians explains much of the anxiety of Matthias. The majority of the nation adhered to the new faith while the king himself was a Catholic. Also, one part of the nation was under the protection of the Turks, yet it was in frequent communication with the other part, to which it felt attached by a strong sense of solidarity. 


\section{DEVELOPMENT OF HUNGARIAN LIBERTY.}

This may explain the policy of Matthias, but it does not justify it. The ling sought his support in the foreign troops. His aim was to establish his rule with their aid. As we have seen, he was ready to commence war with the Turks solely in order that he might have some pretext for bringing a foreign army into Hungary.

He did not wish to conquer Transylvania because he knew that he could not retain it unless he also overcame the Turlis, but he wished to place it under a ruler who would serve his aims. First he intrigued against one of the Transylvanian rulers, Gabriel Báthory. He attacked Báthory but was defeated. When afterwards, partly in consequence of the intrigues of the Viennese Court, but chiefly through his own fault, Báthory fell, the Court carried on the same intrigue against his successor.

In opposition to Bethlen the Court party tried to raise Homonnay, a Catholic magnate, to the throne of Transylvania, but they made him promise that if the king desired it, he would admit foreign troops. From Bethlen the king demanded that he should allow German troops to enter the fortress of Nagy Várad.

In every Diet that the king convened, he tried to gain permission to call in foreign troops. His argument was that foreign powers would not give money for military purposes unless the laws excluding foreign troops were repealed.

Besides this constant effort on the part of the king, he sought to free himself from the Palatine. When Illésházy died the king appealed to the Estates not to maintain the expensive office of Palatine, and when the Estates would not fall in with the king's wishes, he tried at least to modify the form of the election. He said that not the king, but the Estates, should nominate four candidates, and the king should choose from them the one he preferred. But even this result he could not accomplish.

After Thurzo's death the king tried to hand over the duties of the Palatine to an executive council appointed 


\section{THE REIGN OF MATTHIAS 11.}

by himself, but he soon found that he could not effect his purpose and accordingly abandoned it.

In 1618 Matthias requested the king of Spain to give him support in money and men, so that he might put an end to the system of free election. In Bohemia he had succeeded in making the nation acknowledge the hereditary right of the dynasty and he now demanded of the Hungarians that they should accept the Archduke Ferdinand as his successor. His aim was to place the dynasty in the position which it had occupied before the crisis precipitated by Rudolf.

The king's efforts, however, were fruitless. He failed in his attempts to begin war with the Turks. The Hungarians openly declared that they were for peace when the Estates of all the dominions of Matthias were assembled at Linz. Nor were the Austrians inclined to give their support for such a war. It was a cruel idea to urge a nation into a war, the issue of which was most uncertain, and to demand its money and its blood, in order to use this sacrifice for the purpose of destroying the nation's Constitution. This nefarious scheme richly deserved the speedy and utter defeat with which it met.

In 1618, Matthias had also to abandon, on the advice of his Hungarian council, the plan of leading Spanish troops into Hungary.

$\Lambda$ s regards Transylvania the Viennese policy met with no better success. The Court undermined the position of Gabriel Báthory, but he was succeeded by the more talented and therefore more dangerous Gabriel Bethlen.

Bethlen, embittered by the intrigues against him, sought an alliance with the Turks. The northern part of the country also felt some anxiety on account of the struggle of the Court with Transylvania, and this feeling kept alive in the nation the sense of solidarity with that principality. The value of Transylvania's independence was made increasingly evident by the attacks made upon it. 
The king desired that in place of free election the nation should merely "accept" the new king whom he himself should nominate. But the majority of the Estates demanded that the Archduke Ferdinand should be subject to an entirely "free election," meaning by that expression that if the nation chose, it was entitled to elect a king from some other dynasty.

At last the king and the nation compromised upon a certain kind of election which both parties understood differently. The king was convinced that there was only freedom of choice within the limits of the Habsburg family, while the Estates thought that their right of election was entirely unrestricted. It is certain, however, that the king had abandoned some of his pretensions, because instead of a mere " acceptance" of his successor, the "election" of one was the final result of the long controversy.

The careful behaviour of Matthias was due to the political situation. Matthias was weaker than his predecessors. The great storm roused by Rudolf did not pass away without leaving serious traces. The royal prerogatives were everywhere limited. Decentralisation and the authority of the Estates prevailed. If Matthias had tried to carry his point by force he would have received no support from any quarter. Every one of his countries wished to live its own independent life. All were jealous of each other and the only common feeling among them was fear of the imperial power. In 1613 Mathias himself wrote, after having discerned the political tendencies of Bohemia, Moravia and Upper Austria, that al! his provinces were drifting away from the centre and that after his death the monarchy would fall to pieces. Only in defence of their religion and of the authority of the Estates were the various dominions of the Habsburgs ready to form an alliance. If the king had attacked their independence, the alliance which had broken the power of Rudolf would have sprung to life again.

The most eminent Austrian statesman of that period, 
Zierotin, sought to give a permanent organisation to that alliance. He wished to create a body from the Estates of the various countries which could exercise a decisive power at the centre, and could counteract the imperialist policy. But Matthias dreaded so much the idea of his various dominions acting in concert that when in 1614 he summoned their representatives to Linz in order to plan the Turkish war, he did not hold a joint meeting of them all, but asked them to give their opinions in writing.

It was due to the victories of the Hungarians and to the diplomacy of Hungarian statesmen that the ling could not count on support from any of his countrics against the new order, which had been built up by the alliance of the Estates, and remained under their joint protection.

The state of his relations with the rest of Europe also compelled Matthias to maintain peace. The Emperor's title was a mere empty sound. The German Empire was a body without any soul to control its various members. The league of Protestants known as the Union became the deadly enemy of the Habsburgs.

The situation of Matthias was made still more difficult by the animosity between himself and Rudolf, who shrank from no means of revenge that presented itself, and who sought to rouse the Estates against Matthias.

On the west, Henry IV. of France for some time threatened the Habsburg dynasty. The French nation had witnessed the horrors of a religious war, and had welcomed Henry IV. as its saviour. That great man won for France a most favourable position. He stood at the head of a united people, and he wished to employ its strength in war against the Habsburgs. It looked as though the world was on the eve of a revival of the great war which had been commenced by Francis I. and Charles V., except that now the parts were reversed.

Henry was the aggressor, and the more formidable 
of the two opponents. He was organising his armies with the view of breaking the power of the Habsburgs, and of transforming the map of Europe, when a fanatic murdered him (1610).

The Habsburgs had escaped the danger from the west, but on the east the Sultan's sword was still drawn against them. Every conflict between king and people would have benefited the Sultan, and would have helped to make him master of the country.

In Hungary itself the king's situation did not improve. In consequence of the peace treaty with the Turks there were fewer foreign soldiers in the country than formerly. Since the time of Bocskay the Hungarian government had become very much stronger. The king's sehemes made a very bad impression upon the members of the government, and were opposed even by those who stood nearest to the king. One powerful defence of national freedom was the prevailing decentralisation. The counties lived an active and independent political life, and were vigilant defenders of the Constitution and of Protestantism. It was their action that checked the intrigues of the Viennese Court, and frustrated the attacks upon Transylvania. They made war upon Homonnay, who served the aims of the Viennese Court. They defended Transylvania, which subsequently repaid them bountifully for their help. Transylvania became a factor which forced the Court to be conciliatory. It was like an obstacle in the king's path which he strove in vain to remove.

The temper of the Hungarians was less conciliatory during the reign of Matthias than it had been before. Rudolf's action had increased their distrust. They were not inclined to part with any of their rights, and they refused peremptorily any demand of the king in that direction. The Diet repeatedly confirmed what the king desired to be cancelled. Since Bocskay's insurrection the Hungarian Constitution could only be maimed by violent means, but the king did not dare to employ them. 


\section{THE REIGN OF MAT'THIAS 11.}

That is why all his efforts remained fruitless, and the bulwark erected by Bocskay in defence of the Constitution remained intact.

But although Matthias could not change the legal situation to his advantage, and the laws which made his position more difficult than that of his successors remained unrepealed, he was more successful in his manipulation of the existing laws. He could not regain what the legislators had acquired for themselves, but he could hinder them from reaping any benefit from it.

Hungarian affairs should have been managed exclusively by Hungarian councillors. And yet, just as before, the Court Council was the supreme government. Even the negotiations concerning a new peace with the Turks were carried on by Khlesl.

Matthias knew well enough that Thurzó or Illésházy would have served his interests much better than Khlesl as regards the defining of the frontiers, because for them to surrender a portion of Hungarian territory would have been like giving their very life blood, but they would not have supplied the king with an opportunity of restoring the Germans to their " former dignity" in Hungary.

Nilitary matters were controlled by the Court Council, and when the Hungarian Council complained, the answer was that it would be impossible for the Court Council not to have the control since the frontier fortresses were maintained by lustrian money, and in order to pacify the Hungarians the ling was advised by his council to nominate Hungarians as members of the various Court Councils. But the king did not do even this, and the country's military affairs were entirely managed by foreigners in Vienna.

According to Hungarian law financial matters also should have been entirely in Hungarian hands, but they were not. The office of Hungarian Treasurer was not filled, the custom officials were largely foreigners, and the mining towns were governed from Vienna. The Palatine complained, but in vain. 


\section{DEVELOPMENT OF HUNGARIAN LIBERTY.}

The law decreed that all foreign soldiers should be removed from the country, but how could Matthias carry out the law when his great aim was to bring intu the country as many foreign soldiers as possible? The commanders of the fortresses were foreigners, the Banus did not recover his authority, and the Croatian and Slaronian fortresses were under the direct command of the Archduke Ferdinand, of Gratz, while their garrisons were German.

The king had a strong argument against the legislators in the circumstance that Hungary had often appealed to the neighbouring countries for money. The German soldiers themselves said that they would not leave the Croatian fortresses because they belonged to Ferdinand as much as Györ belonged to the German Empire. The weak point in Hungary's position from the beginning of the Habsburg regime had been the inability of the country to supply its own needs. Legal independence could not become effective because financial dependence did not cease even in times of peace.

The final result of the reign of Matthias was a weakening of the State. The king could not compel the Estates to submit to a maiming of the Constitution, but on the other hand the Estates could not compel the king to respect the laws. Both parties were strong enough for purposes of defence, but neither was able to win a complete victory over the other. This situation was just as disadvantageous to the king as to the nation. The king's attitude was unquestionably wrong. Without mentioning the moral aspect of the question, even from the point of view of expediency, a policy which yielded such fruits was to be condemned. The king lost the nation's sympathy, and gained little real power in exchange. His rule retained its foreign character, and, in spite of a farourable beginning, proved just as unpopular as that of Ferdinand I. or Maximilian. Moreover, it was weaker than theirs had been, for Matthias himself had helped to re-build those constitutional bulwarks which had been 


\section{THE REIGN OF MATTHIAS 11.}

battered by his predecessors. The foreign soldiers remained in the country and embittered public feeling, while they were not sufficiently numerous to put down the opposition aroused by their presence.

This policy was the more foolish on the part of Matthias, because if he had respected the country's independence he could have considerably increased his power as king of Hungary. The religious situation would have given him an excellent opportunity.

During the reign of Matthias the religious affairs of the nation were in a still more critical condition than political matters. The king was just as much opposed to religious liberty as to political liberty. When the Austrian Estates demanded religious privileges from him he complained bitterly that he would be unhappy whatever his decision was, for he would lose either his crown or his salvation.

Yet it was not the king who disturbed the peace of the religious world; that was the work of the Church.

Protestantism had by that time become very strong. Matthias was not fanatical; he was rather a man of half measures. He wished to assure both his throne and his salvation, and accordingly refrained from energetic perserution, but whenever and wherever he could injure the new faith, contrary to the law, he did so. He thus made the Protestants his enemies, yet he did not content the Catholics.

What Matthias did not dare to do, was brought about by the spirit of the times. Catholicism was inspired with new ardour. The most important feature of the reign of Matthias II. was the attack made by the Catholics upon Protestantism.

The Jesuits began to develop great activity, and among the higher priesthood also an intransigent spirit manifested itself. They did all in their power to stir the people out of their tolerance and indifference.

In Hungary, Archbishop Peter Pázmány was the most powerful representative of the new tendency. In that 


\section{DEVELOPAENT OF HUNGARIAN LIBER'TY.}

country he personified the Catholic reaction. Pázmány was a man of eminent talents, a great orator, a clever logician whose arguments were sharp as a sword, and a consummate artist in the use of Hungarian literary prose. He was no apostle of Christian love and charity, such as might be adnired as much by members of other denominations as by his own. Yet he deserved respect, for he was entirely sincere. He persecuted the Protestants from no other motives than those supplied by religious fanaticism, and although he was of a warlike disposition, and masterful, yet he was not so implacable as many other persecutors of his time. It was chiefly by impressing men's minds that he attained his great successes. He wished to win real adherents to the Church, and he knew he could not do that by violent means. He therefore relied on arguments, on the exemplary conduct of the priests, on the influence of schools, and on awakening real convictions. When in 1608 the king asked him whether it was compatible with the duty of a Christian to sanction relisious liberty, Pázmány replied that one should not only consider what one ought to do, but also what was possible, and the violent suppression of Protestantism would certainly drive the Hungarians to seek the protection of the Turks.

Pázmány's predecessor, Forgách, and several of his successors, were harder and more indomitable than he. He did not try to alter the laws of the country to the adrantage of the Catholics, but in social life he adrocated forcible methods in religious matters. He was glad if a landowner compelled his peasants to accept Catholicism, or if churches were taken by force from the Protestants.

At a time when religion and politics were so closely bound together, Pázmány could not keep aloof from politics, especially as he wielded so much power as Archbichop of Esztergom. He had many enemies. As a man who fought passionately for his convictions and his party, he was hated by many. During his lifetime 


\section{THE REIGN OF MATTHLAS II.}

there were several who doubted his patriotism, and after his death the accusations were repeated. These accusations, however, deserve no credence. It may be that patriotism was not the mainspring of his actions; he was probably a Catholic first and a Hungarian afterwards; but as far as anything outside his religion could interest him he lived for his country. In his letters he always spoke with heartfelt warmth of his country. We can believe those letters. To be a good patriot is a racial quality with the Hungarians, and a man who cultivated the national language with so much love, who was so versed in national lore, who was so proud of his noble descent, and was such an eminent personality, could not have been indifferent to the sufferings of his country. And just because he loved that country he wished it to follow " the only true faith." He looked for the support of that faith to the dynasty. The religious salvation and political welfare of the nation he expected from the same source. That was why he was a more fervent adherent of the dynasty than most of the Hungarians.

In 1616 Pázmány wrote: "It is impossible for Hungary to remain entire between those two powerful empires; either we must be swallowed up by the pagans, or else we must seek protection beneath the wings of the neighbouring Christian power." He therefore approved of many things to which the majority of the nation objected, and was ready to yield such power to the king as made the nation fear for its Constitution. When the nation clamoured for the unrestricted right of electing its king, he declared himself in favour of the undisputed succession of the Habsburgs. When the Diet demanded the election of a Palatine, Pázmány was willing to leave that office unfilled. He did not look with friendly eyes at the enormous power of the Palatine. He would have preferred a state of affairs in which the head of the Hungarian Church, the Archbishop of Esztergom, that is to say, himself, could play the leading part.

When public opinion turned against the dynasty 


\section{DEVELOPMENT OF HUNGARIAN LIBERTY.}

Pámány even approved of the introduction of German troops into Hungary, because it was in the king's armed forces that he saw the defence of the religion and the policy which he favoured. He realised that the salvation of both king and country depended on the existence of a good understanding between them, and he endeavoured to induce the nation to adopt an attitude that might awaken the king's confidence, while on the other hand, he sought to grive such a tendency to the king's policy as would serve the interests of the nation. He often recommended that Transylvania slould be ruled by an independent Hungarian prince, who would be supported by the Turks, but it is doubtful whether he was sincere in offering this advice.

In independent Transylvania, protected by the Turks, was entirely opposed to the interests of Catholicism, and to the policy of Pámany, who favoured the western alliance. It is hard to believe that Pázmány would have raised his voice on behalf of the maintenance of the rule of Bethlen and Rákóczy in Transylrania if he had had any hopes of their being conquered. As that was not likely, Pázmány thought that peace was the most advisable policy.

Every action of Pázmány was inspired by the conviction that the Turks and the Protestants were equally dangerous, and that the nation's earthly welfare and future salvation alike demanded the strengthening of the Habsburgs' power. Royalism was stronger in Pázmány than in most of his contemporaries.

The bad policy of the dynasty was the cause of all the mischief. He who really approved of the Habsburg system of government could hardly be a good Hungarian. The man, however, who merely acquiesced in that system, in spite of its defects, because he thought that the interests of the country demanded that the dynasty should be supported, may have been as true a patriot as the nation possessed.

Pázmány's work was epoch-making. Success could 


\section{THE REIGN OF MATTHIAS II.}

not fail to attend his efforts. Catholicism began to drive out Protestantism everywhere. In the last Diet convened by Matthias the Catholics among the magnates were more numerous than the Protestants. The political lifc of the nation gained a new factor. There was a powerful new political and religious party

What was the effect upon the nation of the revival of Catholicism? It became a link between king and nation. The Catholic dynasty and the Catholic nation had at least a few points in common. They learned to look at events from the same point of view. Mutual confidence and harmonious co-operation at least became possible.

But did not this new state of affairs endanger the country's freedom? If the trustworthiness of the Ilungarians had induced the king to govern Hungary with the help of Hungarians, and to put an end to the foreign régime, the nation would have entered upon a new and happier epoch. The mission of the Catholic party was to influence the dynasty in farour of the nation and the importance of this mission was incalculable. But if the Catholics did not succeed, there was danger lest the foreign spirit of the Court should draw the Catholic party under its spell, and if the crown should continue to pursue a wrong policy, like that of Rudolf, the division of the people into rival denominations would weaken the nation's power of resistance.

The situation contained both good and bad possibilities. During the reign of Matthias II. the Catholic reaction did more harm than good. Pázmány and his followers succeeded in eliminating certain wrong features in the governing system of Mathias, and they also created a somewhat more conciliatory spirit among the Estates, but they could not control the actions of the Court. Mat thias would have gained much if he had drawn nearer to the Hungarians, but he remained so foreign that even the Catholics could not conciliate the nation, but only drew its mistrust upon themselves.

In the sixteenth century, when Protestantism com- 


\section{DEVELOPMENT OF HUNGARIAN LIBER'TY.}

wenced to spread, Catholicism was in a wealiened condition in Hungary, and as the Protestants adopted a very moderate attitude a severe conflict was avoided. But now the Catholic reaction found a strong and well-organised I'rotestant party. Steel clashed with steel. The denominational spirit was stronger than before, and it gave rise to a conflict which eclipsed even national considerations. Now there were no longer opposing parties, but downright enemies. The spirit of intolerance grew rapidly. Pazmany complained that there were still some who thought that good Protestants might be saved. Unfortunately those who beliered this became more and more scarce. Pázmány took care that such an opinion should be eradicated. The intransigent archbishop spoke with indignation of the circumstance that there were churches in which different denominations held religious services, but he soon destroyed the spirit that had made this possible.

The Protestants did not remain inactive. Hitherto they had formed an immense majority of the nation, and they had used their power temperately, but now, seeing the danger which threatened them, they did not shrink from using violent means. The chief problem was that of the churches. It is true that the law granted religious liberty even to the peasants, but the churches themselves belonged to the landowners, and consequently Protestant villages belonging to Catholic landowners remained without churches.

Protestant landowners could of course use the same weapons as their opponents, but as the Catholic faith had spread most among the nobles, the Catholics gained most advantage from the situation. The Protestants were, therefore, anxious to secure the use of the churches for the peasants. The struggle was carried on with arguments as well as with riolence, in the Diet and outside it.

Denominational differences were added to political animosities, and the reign of Matthias ended in party conflicts, discontent, and disorder. The peace which had 


\section{THE REIGN OF MATTHI.IS II.}

prevailed when Matthias ascended the throne had disappeared. Only a spark was needed to kindle a great conflagration, and to make Hungary, that long suffering country, once more the scene of war and desolation.

THE END.

Printed by the Fexhill Publishing and Printing Co.. Ltd., Bexhill-on-Sea. 
DATE DUE

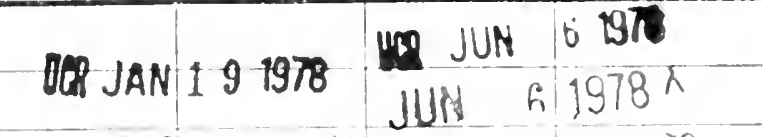
JAN $201978 \times$ ULR JUIH 207978

UR FEB 31978

FFP 7 - $107 \%$

UQR FEB 211978

FEB \& 4 H78

LA MAR 14 OTB

Mar 11 1978 .

UAR I 1 OH

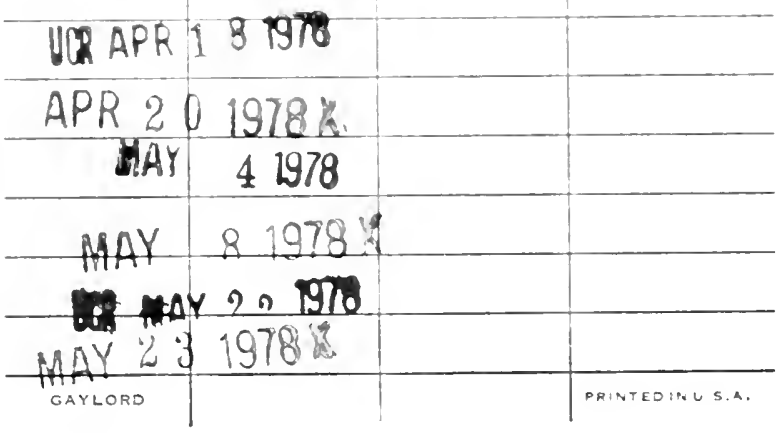



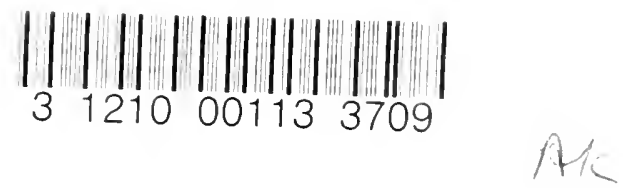

UC SOUTHERN REGIONAL LIBRARY FACILITY

L ||

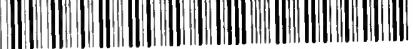

AA 0011430014 
$677^{9}$

40

$\frac{1}{4}$

the Whe

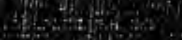

(1)

1.

60 of

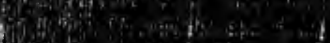

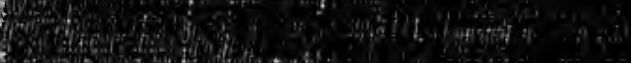

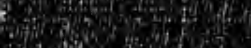

(19)

29. If 2 .

19.

1.9.

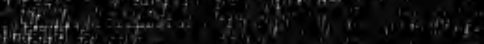

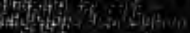

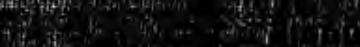

10 (19.

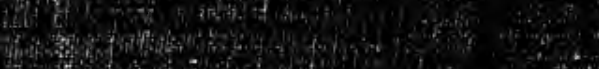

(5)

4.

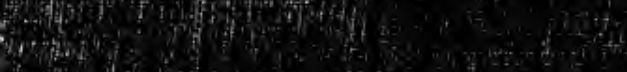

Het

Hilly

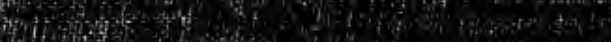

Af

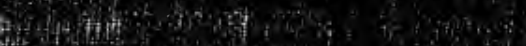

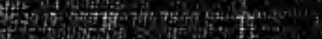

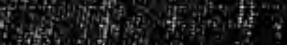

13.

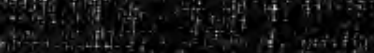

(5)

1.

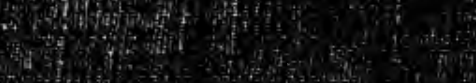

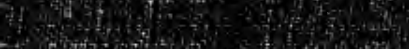

-

40 年

1.6.

40

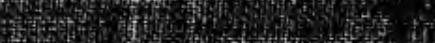

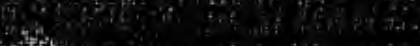

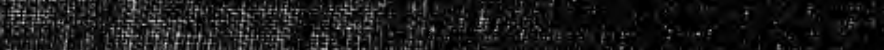

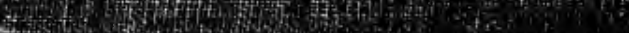

314.

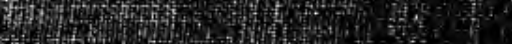

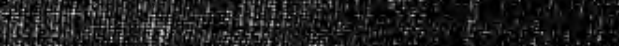

H(x)

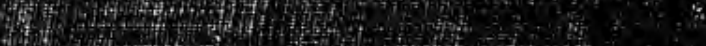

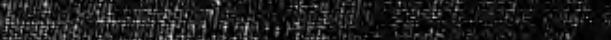

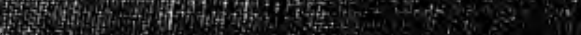

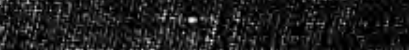

Q78

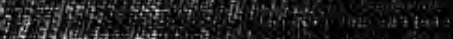

(5) 